Rosa Maria Tóro Tonissi

\title{
PERCEPÇÃO E CARACTERIZAÇÃO AMBIENTAIS DA ÁREA VERDE DA MICROBACIA DO CÓRREGO DA ÁGUA QUENTE (SÃO CARLOS, SP) COMO ETAPAS DE UM PROCESSO DE EDUCAÇÃO AMBIENTAL
}

Tese apresentada à Escola de Engenharia de São Carlos da Universidade de São Paulo como parte dos requisitos para a obtenção do Título de Doutora em Ciências da Engenharia Ambiental.

Orientadora: $\operatorname{Prof}^{\mathrm{a}} \mathrm{Dr}^{\mathrm{a}}$ Haydée Torres de Oliveira

São Carlos

2005 
Ficha catalográfica preparada pela Seção de Tratamento da Informação do Serviço de Biblioteca - EESC/USP

\section{Tonissi, Rosa Maria Tóro}

T665p

Percepção e caracterização ambientais da área verde da microbacia do

córrego da Água Quente (São Carlos, SP) como etapas de um processo de educação ambiental / Rosa Maria Tóro Tonissi. -- São Carlos, 2005. 2005.

Tese (Doutorado) -- Escola de Engenharia de São Carlos-Universidade de São Paulo,

Área: Ciências da Engenharia Ambiental.

Orientadora: Profa. Dra. Haydée Torres de Oliveira.

1. Percepção ambiental. 2. Topofilia. 3. Educação ambiental escolar e comunitária. 4. Participação. 


\section{FOLHA DE JULGAMENTO}

Candidata: Bacharel ROSA MARIA TÓRO TONISSI

Tese defendida e julgada em 14-07-2005 perante a Comissão Julgadora:

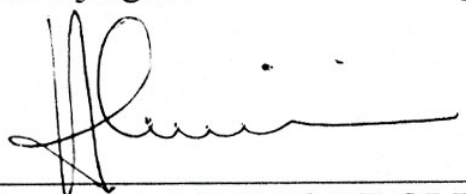

Profa. Dra. HAYDEE TORRES DE OLIVEIRA (Orientador)

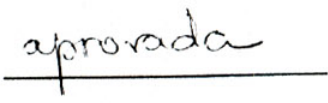

(Universidade Federal de São Carlos/UFSCar)
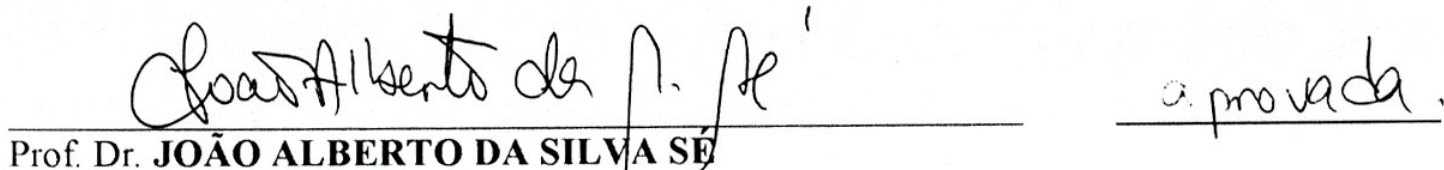

(Centro Universitário de Araraquara/UNIARA)

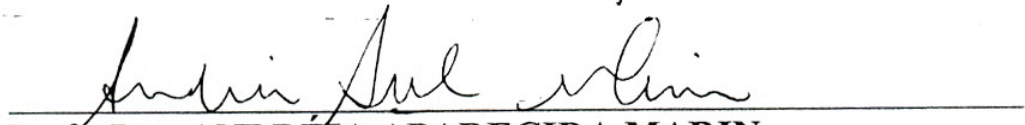

Prola. Dra. ANDRÉIA APARECIDA MARIN

(Universidade Federal do Paraná/UFPR)

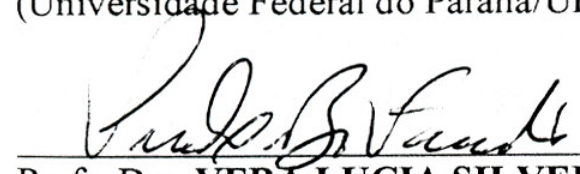

Profa. Dra. VERA LUCIA SILVEIRA BOTTA FERRANTE

(Centro Universitário de Araraquara/UNIARA)

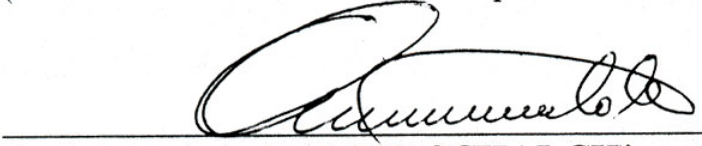

Prof. Associado VALDIR SCHALCH

aprovader

(Escola de Engenharia de São Carlos/EESC)

APROVADA

Prof. Associado EVALDO LUIZ GAETA ESPINDOLA

Coordenador do Programa de P8s-Graduação em Ciências da

Engenharia Ambiental

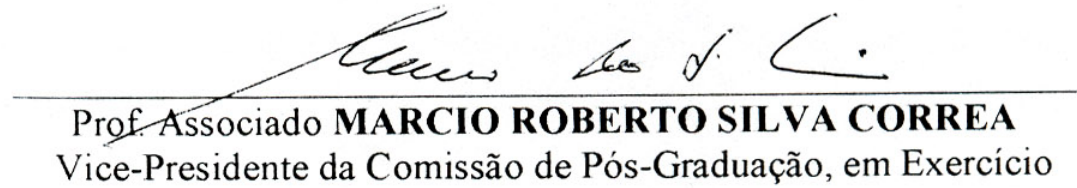


A Deus, que por Seu Amor infinito, nos faz cocriadoras(es) e cuidadoras(es) da vida na Terra.

Aos meus pais, Estéfano e Luzia, pela oportunidade de nascer, viver, ser amada, e nessa vida aprender acima de tudo, a amar a todas as formas de vida, como parte de cada uma delas.

A Fabiano, pela vida compartilhada.

A J osé Estéfano, quem esteve mais perto de mim e mais sentiu comigo cada momento dessa caminhada, colorindo todos eles com seu sorriso.

Ao meu irmão Paulo, exemplo de vida, de tolerância, de amorosidade, de paz.

À Haydée, que me mostrou o caminho para fazer o bem através da Educação Ambiental.

A todos os sujeitos participantes deste trabalho, que me acolheram e tanto me ensinaram sobre a vida. 


\section{AGRADECIMENTOS}

A Deus, pela oportunidade de concluir mais esta etapa.

À Prof ${ }^{\mathrm{a}} \operatorname{Dr}^{\mathrm{a}}$ Haydée Torres de Oliveira, quem sempre alimentou minha fé na Educação Ambiental para a justiça social, pela dedicada orientação nesta pesquisa.

Ao Prof. Dr. Evaldo Luís Gaeta Espíndola, Coordenador do Programa de Pós-Graduação, pela sua competência e incansável dedicação, que garantem o sucesso deste programa essencial para a minha formação.

À Prof ${ }^{\mathrm{a}} \operatorname{Dr}^{\mathrm{a}}$ Andréia Aparecida Marin, pelo acolhimento e amizade sempre, e pelas preciosas sugestões para este trabalho e para tantos momentos da minha vida acadêmica.

À Prof ${ }^{\mathrm{a}} \operatorname{Dr}^{\mathrm{a}}$ Vera Lúcia Botta Ferrante, membro da banca examinadora e a quem sou unida pelo “código do coração”, pelas preciosas contribuições.

Ao Prof. Dr. João Alberto da Silva Sé, membro da banca examinadora, amigo, exemplo e referência fundamental para esta pesquisa.

Ao Prof. Dr. Valdir Schalch, membro de banca examinadora, exemplo de pessoa e caríssimo pela sua perseverança e pela sua esperança na Educação Ambiental,

Ao Prof. Dr. Carlos Eduardo Matheus, membro da banca de qualificação, pela contribuição neste, e pela valiosa Especialização em EA da qual tive oportunidade de participar e que em 2005 já completa 10 anos. Parabéns!

À $\operatorname{Prof}^{\mathrm{a}} \operatorname{Dr}^{\mathrm{a}}$ Geria Maria Montanaro, pelas contribuições como membro da banca de qualificação e por acreditar e investir na recuperação da área verde onde desenvolvemos esta pesquisa.

Aos(às) professores(as) e funcionários(as) do Centro de Recursos Hídricos e Ecologia Aplicada, pela amizade e competência, em especial

ao Miro, por seu meu fiel companheiro de coletas,

Amândio e Marcelo, pela paciência e orientação nas análises limnológicas,

Claudete e Wellington pela paciência e dedicação na secretaria,

À Mara, pelo excelente trabalho na biblioteca.

Ao Sr. Adão e demais funcionários da gráfica da EESC, pela simpatia e boa vontade.

À Prof ${ }^{a}$ Silvia A. M. dos Santos, coordenadora do setor de Biologia e Educação Ambiental, ao técnico Alessandro e às(aos) monitoras(es) do setor de Biologia da Coordenadoria de Divulgação Científica e Cultural da Universidade de São Paulo, pela amizade e pelas orientações na confecção da maquete da microbacia do córrego da Água Quente.

Às(aos) professoras(es) Dr. Jairo, $\operatorname{Dr}^{\mathrm{a}}$ Alaíde, Solange e Maria Zélia, a quem devo minhas primeiras reflexões e pesquisas.

Às(aos) amigas(os) qual irmãos da Escola Edésio Castanho e Escola Católica e Associação Querigma, pelos muitos momentos compartilhados e pelas tantas aprendizagens.

Às(aos) queridas(os) companheiras(os) do GEPEA, onde aprendi a importância do pensar coletivo. 
À comunidade escolar e especialmente à professora Roberta Bolzan Simões, nossa co-autora neste trabalho, e às(aos) caras(os) educandas(os) das escolas EE Aracy Leite Pereira Lopes, EE Orlando Perez e EE Maria Ramos, pela participação nesta pesquisa.

A todas(os) as(os) pessoas da microbacia do córrego da Água Quente que com boa vontade e interesse, aceitaram participar deste trabalho.

Aos docentes Prof. Dr. Carlos Alberto Peret e Prof. Dr. Cristiano Santos Neto da Universidade Federal de São Carlos pelas orientações nas análises numéricas.

Ao docente Prof. Dr. Mario Eduardo Mendiondo, da Universidade de São Paulo e especialmente ao Rogério pelos dados climatológicos.

Ao biólogo Rodrigo Z. Damiano, fotógrafo da natureza, que possibilitou o levantamento da avifauna da microbacia do córrego da Água Quente.

À Secretaria de Desenvolvimento Urbano e Habitação da Prefeitura Municipal de São Carlos pelo material cedido.

Ao caríssimo senhor Antônio de Oliveira, morador do bairro Jardim Gonzaga, possuidor de rica experiência sobre vegetação e fauna e de um coração maior que a microbacia. Nosso co-autor.

Ao Sr. Antônio e funcionários do GM Auto-Posto, pelo apoio durante as coletas.

Ao CNPQ, pelo financiamento para este projeto.

À Elaine, minha companheira dedicada e amorosa, por cuidar do José Estéfano como mãe.

Aos queridos Flávia, Otávio e Daniel por todo apoio durante a realização deste. Vocês são pessoas muito especiais.

Ao Dr. Valter Fausto, pessoa especial em nossa vida, que vive verdadeiramente o sentido da caridade, e que é exemplo de fé e competência profissional.

A todos os amigos e amigas que sempre me apoiaram neste trabalho, e que, por serem tantos, preferi não citar, mas dizer que sem eles esse trabalho teria menos sentido.

Ao meu pai Estéfano Tóro e à minha mãe Luzia de Morais Nunes Tóro, meus pilares nesta jornada.

Aos meus sogros José Luis Tonissi e Silvia Helena Botta Tonissi e Família, por todo o apoio durante a realização deste.

A Fabiano e José Estéfano, que dividiram comigo as alegrias e dificuldades desta pesquisa, e me ajudaram a conciliar vida pessoal e profissional.

Toda minha gratidão. 
PARA QUEEDUCAR?

Para recuperar a harmonia fundamental que não destrói, que não explora, que não abusa, que não pretende dominar o mundo natural, mas que deseja conhecê-lo na aceitação e respeito para que o bem-estar humano se dê no bem-estar da natureza em que se vive.

(Humberto Maturana) 


\section{RESUMO}

TÓRO-TONISSI, R. M. (2005). Percepção e caracterização ambientais da área verde da microbacia do córrego da Água Quente (São Carlos, SP) como etapas de um processo de Educação Ambiental. Tese (Doutorado) - Escola de Engenharia de São Carlos, Universidade de São Paulo, São Carlos.

A Educação Ambiental constitui um valioso meio de despertar nos cidadãos e cidadãs, a partir de reflexões sobre a ética da relação ser humano-ambiente, a compreensão da necessidade de se investir em um modelo de gestão ambiental integrada e participativa dos municípios, como um passo importante para a consolidação de um modelo mais sustentável e justo de sociedade. A área escolhida para o desenvolvimento deste trabalho pertence a microbacia do córrego da Água Quente (São Carlos, SP), e se destaca pela beleza da paisagem e pela sua importância ambiental, em contraste com seu adiantado estágio de degradação ambiental, decorrente da interferência antrópica mal planejada. Através da caracterização ambiental desta área verde (com ênfase na qualidade da água e na biodiversidade) e do estudo da percepção e dos saberes locais da comunidade do entorno e de estudantes do ensino médio de três escolas estaduais inseridas na microbacia em relação a esse ecossistema, objetivamos gerar subsídios para o desenvolvimento de projetos de EA escolar e comunitária que visem a recuperação e conservação da área verde. A caracterização ambiental confirmou a má qualidade dos corpos d'água e a presença de um número bastante significativo de espécies animais e vegetais (considerando-se que é uma área impactada). A análise da percepção ambiental e dos saberes locais revelou que a maioria das(os) participantes possui com a área uma relação de topofilia, baseada principalmente no sentimento de pertencimento e na valorização estética desta paisagem, o que reflete em uma consciência ecológica. Entre as pessoas da comunidade, a maioria indicou o poder público como o responsável pela gestão da área verde e pelo atual estágio de degradação, desconsiderando o papel da população local, enquanto que a maioria das(os) estudantes acredita que cabe à comunidade local decidir sobre o manejo da área. Finalmente, apesar da evidente falta de participação política no que diz respeito às decisões sobre o manejo da área verde, ficou evidente, através das sugestões de manejo, que a maioria entende a importância da recuperação e conservação da área e percebe o seu grande potencial como espaço de lazer para a população sendo unânime, nos dois grupos participantes, o desejo de participar desse processo.

Palavras-chave: percepção ambiental; topofilia; educação ambiental escolar e comunitária; participação; microbacia hidrográfica. 


\section{ABSTRACT}

TÓRO-TONISSI, R. M. (2005). Environmental perception and landscape chacarcterization of Água Quente stream watershed (São Carlos, SP) as a Evironmental Education process stage. Ph.D. Thesis - Escola de Engenharia de São Carlos, Universidade de São Paulo, São Carlos, 2005.

Environmental Education with an ethic basis performs a valious way to help citizens comprehension of the importance to invest in integrated and participative municipal environmental management model as an important step to consolidate a fairy and sutainable society. The choosen area to develop this study is located in Água Quente stream watershed (São Carlos, SP) which is distinguished by its landscape and environmental attributes which oppose to the advanced degree of environmental degradation due an anthropic action not planned. Through landscape characterization (with emphasis to water quality and biodiversity) together with environmental perception plus knowledge about this ecossystem from inhabitants of the surround area and students of three public high school located into the watershed, we aim generate subsidies to environmental education programs and projects in schools and with community which seek landscape restoration. Limnological studies of Água Quente stream confirmed the low water quality of water bodies. Avian survey showed that in the region occur a significative number of species despite area impactation. Vegetation studies showed that the area has a high variety of plant species althought few Cerrado and Forest vegetation sites remained. Evironmental perception and people knowledge showed that majority of local dwellers has a topophilic relation based mainly in a "belonging feeling", in ecological conscienciounes and valorization of landscape aesthetic. Among community people was mainly indicated that public government is responsible for area management while students believe that community should decide about area destinations. Analysing environmental management sugestions pointed by community and students is clear that everyone undestands the importance of restoration and conservation importance for the watershed and notice its great potencial as a laisure place.

Keywords: environmental perception; topophilia; environmental education in school and comunnity; participation, watershed. 


\section{Lista de ilustrações}

Figura 1: Características fundamentais da Educação Ambiental............................. 32

Figura 2: Vista panorâmica da microbacia do Córrego da Água Quente.................. 48

Figura 3: Localização de São Carlos - Estado de São Paulo................................... 52

Figura 4: Divisão das 22 Unidades de Gerenciamento de Recursos Hídricos do Estado de São Paulo.......................................................................................... 55

Figura 5: Divisão do Município de São Carlos em bacias hidrográficas ................. 59

Figura 6: Microbacias urbanas de São Carlos. ................................................... 61

Figura 7: Tributários da bacia hidrográfica do Rio do Monjolinho. ........................ 63

Figura 8: Ocupação urbana, Planimetria e Altimetria da microbacia hidrográfica do córrego da Água Quente. ............................................................................. 64

Figura 9: Pedologia da bacia do rio do Monjolinho. ............................................ 66

Figura 10: Vista da bacia e localização dos pontos de coleta e dos bairros participantes

Figuras 11 a 15: Pontos de coleta - N-vale, AQ-Aracy, N-Pacaembu, AQBelvedere e AQ-Gonzaga - da microbacia hidrográfica do Córrego da Água Quente,São Carlos,SP...

Figuras 16 a 19: Pontos de coleta - N-Torres, AQ-Antenor, N-Horta e Foz - da microbacia hidrográfica do Córrego da Água Quente, São Carlos,SP..................... 74

Figura 20: Vistas panorâmicas da área verde. ....................................................... 89

Figura 21: Bromelia balansae (bromeliácea medicinal do cerrado). ....................... 100

Figura 22: Anonna coriacea (fruto comestível). ................................................. 100

Figura 23: Plantas medicinais da área verde (a partir de cima, Baccharis dracunculifolia, Strychnos pseudo-quina e Stryphnodendron adstringens). ........... 101

Figura 24: Espécies ornamentais da área verde (a partir de cima Cedrella fissilis, Vochysia tucanorum e Xylopia aromatica). .......................................................... 102

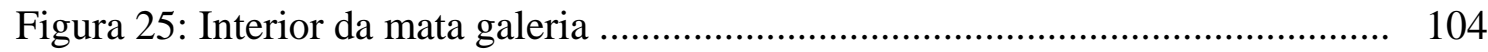

Figura 26: Área de nascentes assoreadas do córrego da Água Quente (presença de voçorocas e resíduos sólidos).

Figura 27: Variações espacial e temporal da temperatura $\left({ }^{\circ} \mathrm{C}\right)$, $\mathrm{pH}$ e condutividade ( $\mu \mathrm{s} / \mathrm{cm}$ ) em nove pontos da microbacia do córrego da Água Quente (São Carlos- 110 SP) entre dezembro de 2001 e dezembro de 2002.

Figura 28: Variações espacial e temporal de oxigênio dissolvido (mg/L) em nove pontos da microbacia do córrego da Água Quente (São Carlos-SP) entre 114 dezembro de 2001 e dezembro de 2002.

Figura 29: Variações espacial e temporal de nitrogênio orgânico total (mg/L), nitrito $(\mu \mathrm{g} / \mathrm{L})$ e nitrato $(\mu \mathrm{g} / \mathrm{L})$ em nove pontos da microbacia do córrego da Água Quente (São Carlos-SP) entre dezembro de 2001 e dezembro de 2002. 
Figura 30: Variações espacial e temporal de amônio $(\mu \mathrm{g} / \mathrm{L})$ em nove pontos da microbacia do córrego da Água Quente (São Carlos-SP) entre dezembro de 2001 e dezembro de 2002.

Figura 31: Variações espacial e temporal de fósforo total, fosfato inorgânico e fosfato total dissolvido $(\mu \mathrm{g} / \mathrm{L})$ em nove pontos da MCAQ entre dezembro de 2001 e dezembro de 2002 .

Figura 32: Variações espacial e temporal de turbidez (NTU) em nove pontos da microbacia do córrego da Água Quente (São Carlos-SP) entre dezembro de 2001 e dezembro de 2002.

Figura 33: Proporção de Eigen-valores e sua representatividade na variância dos dados.

Figura 34: Análise de Componentes Principais, demonstrando o alto grau de interferência do nitrogênio orgânico total e formas fosfatadas.

Figura 35: Agrupamentos de pontos, segundo critérios da análise de componentes principais.

Figura 36: Síntese das inter-relações entre os impactos ambientais da ocupação irregular no bairro Jardim Gonzaga.

Figura 37: Gênero das pessoas entrevistadas.

Figura 38: Faixa etária das(os) entrevistadas(os).

Figura 39: Procedência das pessoas entrevistadas quanto ao estado e à região.

Figura 40: Tempo de residência das pessoas entrevistadas na microbacia do córrego da Água Quente.

Figura 41: Nível de escolaridade das pessoas entrevistadas.

Figura 42: Religiões das pessoas entrevistadas.

Figura 43: Fatores que influenciam na qualidade ambiental segundo a percepção da comunidade de quatro bairros da microbacia do córrego da Água Quente.

Figura 44: Grau de satisfação por morar próximo à área verde.

Figura 45: Percepção da influência da área verde sobre a saúde da população.

Figura 46: Relação entre gênero e o número de pessoas que estiveram na área verde.

Figura 47: Freqüência de visitas à área verde.

Figura 48: Período após a última visita à área verde.

Figura 49: Principais impactos ambientais da área verde, segundo a percepção da comunidade.

Figura 50: Percepção da comunidade em relação à existência de corpos d'água da área verde da MCAQ.

Figura 51: Contato da população com os corpos d’água da área verde da microbacia.

Figura 52: Distribuição das(os) estudantes por escola e por gênero. 
Figura 53: A área verde da microbacia do córrego da Água Quente como temagerador para projetos multidisciplinares.

Figura 54: Organograma da seqüência e inter-relações das análises desenvolvidas. 226

\section{Lista de tabelas}

Tabela 1: Percepção das(os) entrevistadas(os), sobre a relação entre a sua qualidade de vida e a existência da área verde

Tabela 2: Responsáveis pela atual situação dos bairros e da área verde 176

Tabela 3: Responsáveis pelas decisões sobre o manejo da área verde 177

Tabela 4: Sugestões por gênero para o manejo da área verde da MCAQ

Tabela 5: Percepção das(os) estudantes da EE Aracy Pereira Lopes sobre a existência e o sentimento de pertencimento em relação à área verde da microbacia adjacente aos bairros em que residem.

Tabela 6: Percepção das(os) estudantes da EE Orlando Perez sobre a existência e o sentimento de pertencimento em relação à área verde da microbacia adjacente aos bairros em que residem

Tabela 7: Percepção das(os) estudantes da EE Maria Ramos sobre a existência e o sentimento de pertencimento em relação à área verde da microbacia adjacente aos bairros em que residem

Tabela 8: Nomes atribuídos à área verde próxima à escola e número de citações em cada escola

Tabela 9: Pessoas ou instituições responsáveis pela atual qualidade ambiental da área verde da microbacia do córrego da Água Quente, segundo a percepção das(os) estudantes

Tabela 10: Pessoas ou instituições responsáveis pelas decisões sobre o manejo da área verde da microbacia do córrego da Água Quente, segundo a percepção das(os) estudantes

Tabela 11: Sugestões preliminares das(os) estudantes das 3 escolas para o manejo sustentável da área verde da microbacia do córrego da Água Quente

\section{Lista de Quadros}

Quadro 1: Variáveis limnológicas e formas de análise 75

Quadro 2: Avifauna da área verde da microbacia do córrego da Água Quente .......

Quadro 3: Espécies vegetais dos fragmentos de cerrado, cerradão e floresta estacional semidecídua da área verde da MCAQ

Quadro 4: Precipitação e temperatura (máximas e mínimas), nos dias de coleta, na microbacia do Córrego da Água Quente, São Carlos, SP

Quadro 5: Componentes naturais que influenciam na qualidade ambiental

Quadro 6: Relações interpessoais como elementos que influenciam na qualidade ambiental 
Quadro 7: Componentes construídos que influenciam na qualidade ambiental

Quadro 8: Respostas que explicitam a percepção da existência da área verde da microbacia do córrego da água quente e sua relação com a qualidade de vida das pessoas entrevistadas

Quadro 9: Características da área verde, responsáveis por uma influência positiva na qualidade de vida

Quadro 10: Características da área verde responsáveis por uma influência negativa.

Quadro 11: Características da área verde que contribuem para a topofilia

Quadro 12: Percepção em relação à influência da área verde sobre a saúde da comunidade

Quadro 13: Respostas que demonstram sentimento de topofilia e topobia pela área verde

Quadro 14: Tipos de usos da área verde da MCAQ pela comunidade local

Quadro 15: Comparação entre os levantamentos in loco e a percepção da comunidade em relação à avifauna da microbacia do Córrego da Água Quente......

Quadro 16: Percepção da comunidade em relação à fauna (exceto avifauna) da microbacia do Córrego da Água Quente

Quadro 17: Comparação entre o levantamento e a percepção da comunidade em relação à vegetação da microbacia do Córrego da Água Quente

Quadro 18: Comparação entre as propriedades medicinais e outros usos de algumas espécies vegetais descritas pela comunidade e as informações encontradas na literatura

Quadro 19: Componentes da paisagem da MCAQ segundo a percepção das pessoas entrevistadas

Quadro 20: Percepção sobre a qualidade da água no passado e no presente

Quadro 21: Distribuição das(os) estudantes por faixa etária e bairros onde residem

Quadro 22: Descrições mais completas sobre a área verde

Quadro 23: Interpretação do significado da área verde para as(os) estudantes da EE Aracy Pereira Lopes, quanto às relações de topofilia/topofobia

Quadro 24: Interpretação do significado da área verde para as(os) estudantes da EE Orlando Perez, quanto às relações de topofilia/topofobia

Quadro 25: Interpretação do significado da área verde para as(os) estudantes da EE Maria Ramos, quanto às relações de topofilia/topofobia

Quadro 26: Algumas respostas que indicam sentimento de topofilia pela área verde

Quadro 27: Sugestões das(os) estudantes da EE Orlando Perez para o manejo sutentável da área verde da microbacia do córrego da Água Quente .....

Quadro 28: Sugestões das(os) estudantes da EE Maria Ramos para o manejo sutentável da área verde da microbacia do córrego da Água Quente 


\section{LISTA DE ABREVIATURAS E SIGLAS}

ACP - Análise de Componentes Principais

BHRM - Bacia Hidrográfica do Rio Monjolinho

BID - Banco Interamericano de Desenvolvimento

CAQ - Córrego da Água Quente

CDCC - Centro de Divulgação Científica e Cultural

CRHEA - Centro de Recursos Hídricos e Ecologia Aplicada

DAEE - Departamento de Águas e Energia Elétrica

EA - Educação Ambiental

EE - Escola Estadual

IBAMA - Instituto Brasileiro do Meio Ambiente, dos Recursos Naturais Renováveis e da Amazônia Legal

IBGE - Instituto Brasileiro de Geografia e Estatística

MCAQ - Microbacia do Córrego da Água Quente

PMSC - Prefeitura Municipal de São Carlos

SMDSCT - Secretaria Municipal de Desenvolvimento Sustentável, Ciência e

Tecnologia

SNRH - Sistema Nacional de Recursos Hídricos

UGRH - Unidade de gerenciamento de Recursos Hídricos

USP - Universidade de São Paulo

UTM - Universal Transverse Mercator 
SUMÁRIO

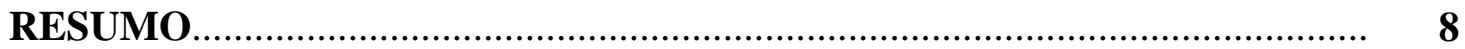

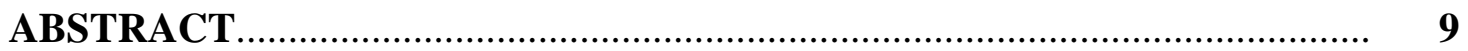

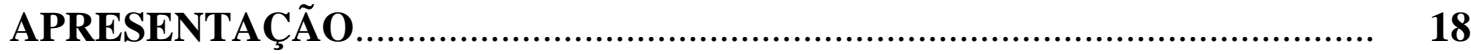

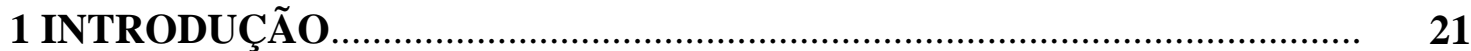

1.1 EDUCAÇÃO AMBIENTAL: Construindo um paradigma para a participação democrática.

1.2 EDUCAÇÃO AMBIENTAL E PESQUISA PARTICIPANTE................... 32

1.3 A PRÁXIS EM EDUCAÇÃO AMBIENTAL ............................................. 35

1.4 PERCEPÇÃO AMBIENTAL............................................................... 38

1.4.1 PERCEPÇÃO DA PAISAGEM............................................................ 40

1.4.1.1 PERCEPÇÃO E VALORIZAÇÃO DA PAISAGEM ........................... 41

1.4.2 PERTENCER AO ESPAÇO PARA TORNÁ-LO LUGAR....................... 43

1.4.2.1 SENTIMENTO DE PERTENÇA: IDENTIFICAR-SE COM LUGAR

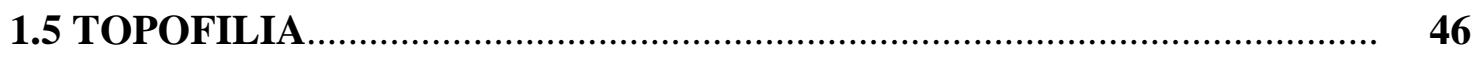

1.6 BACIA HIDROGRÁFICA E PERCEPÇÃO AMBIENTAL: A ABORDAGEM INTEGRADORA NO PROCESSO EDUCATIVO................. 48

1.7 CARACTERIZAÇÃO DA ÁREA DE ESTUDO...................................... 51

1.7.1 A CIDADE DE SÃO CARLOS: QUADRO SÓCIO-ECONÔMICO E AMBIENTAL .............................................................................................. 51

1.7.2 A BACIA HIDROGRÁFICA DO RIO DO MONJOLINHO................... 57

1.7.3 MICROBACIA HIDROGRÁFICA DO CÓRREGO DA ÁGUA

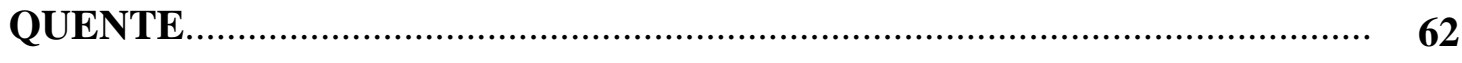

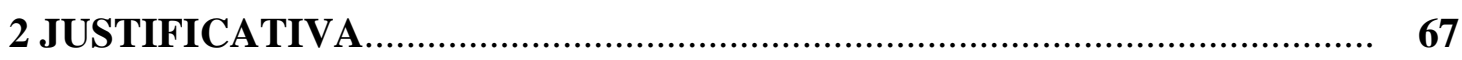

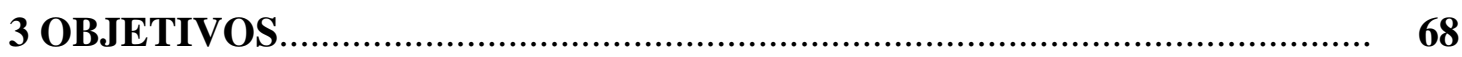

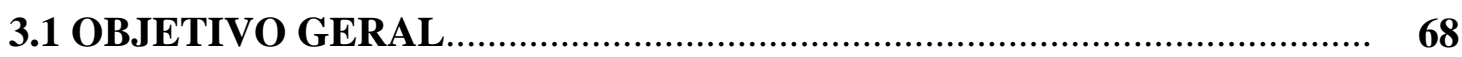

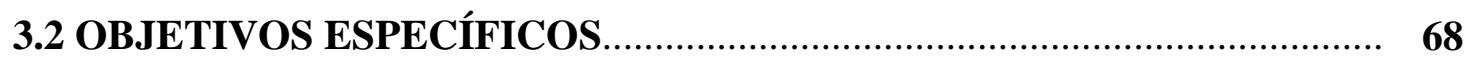

4 PROCEDIMENTOS METODOLÓGICOS.............................................. 69

4.1 TÉCNICAS PARA A INVESTIGAÇÃO DA QUALIDADE DA ÁGUA.... 69

4.1.1 PONTOS DE COLETA E ÉPOCA DAS COLETAS.............................. 69

4.1.1.1 DESCRIÇÃO DOS PONTOS DE COLETA........................................ 67

4.1.2 VARIÁVEIS CLIMATOLÓGICAS...................................................... 75

4.1.3 VARIÁVEIS FÍSICAS, QUÍMICAS E BIOLÓGICAS DA ÁGUA.......... 75 
4.1.3.1 ANÁLISE ESTATÍSTICA DAS CARACTERÍSTICAS 76 LIMNOLÓGICAS

4.2 TÉCNICAS PARA O LEVANTAMENTO DE FAUNA E VEGETAÇÃO. 77

4.2.1 FAUNA

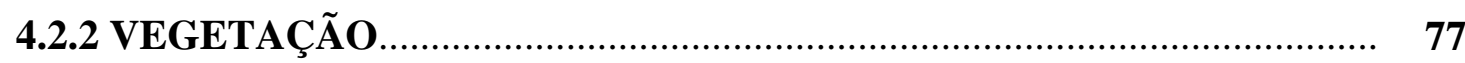

4.3 TÉCNICAS PARA COLETA DE DADOS DE PERCEPÇÃO AMBIENTAL E TOPOFILIA.

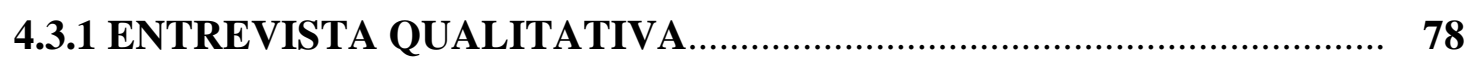

4.3.2 MAPA MENTAL E QUESTIONÁRIO................................................. 83

4.3.2.1 ATIVIDADE COM O MAPA MENTAL........................................... 84

4.3.2.2 ATIVIDADE COM O QUESTIONÁRIO......................................... 84

4.4 VISITA À ÁREA VERDE COM ESTUDANTES E PROFESSORES DA EE ORLANDO PEREZ.

4.5 INTERVENÇÃO EDUCATIVA NAS ESCOLAS EE ORLANDO PEREZ E EE MARIA RAMOS PARA SOCIALIZAÇÃO DOS DADOS, SENSIBILIZAÇÃO E SUGESTÕES DE MANEJO.

5 RESULTADOS - CARACTERIZAÇÃO E PERCEPÇÃO AMBIENTAIS DA ÁREA VERDE DA MICROBACIA DO CÓRREGO DA ÁGUA QUENTE.

5.1 CARACTERIZAÇÃO AMBIENTAL DA ÁREA VERDE DA MICROBACIA DO CÓRREGO DA ÁGUA QUENTE

5.1.1 AVIFAUNA DA ÁREA VERDE

90

5.1.2 VEGETAÇÃO DA ÁREA VERDE ................................................... 94

5.1.3 CÓRREGO DA ÁGUA QUENTE......................................................... 103

5.1.3.1 VARIÁVEIS CLIMATOLÓGICAS $\quad$ …........................................ 106

5.1.3.2 CARACTERIZAÇÃO LIMNOLÓGICA DO CÓRREGO DA ÁGUA QUENTE.

5.1.3.2.1 VARIÁVEIS FÍSICAS, QUÍMICAS E BIOLÓGICAS DA ÁGUA.... 107

5.1.3.2.2 ANÁLISE ESTATÍSTICA DOS DADOS........................... 124

5.1.4 USO E OCUPAÇÃO DA MICROBACIA E AS CONSEQÜÊNCIAS SOBRE A ÁREA VERDE.

5.1.5 SÍNTESE DA CARACTERIZAÇÃO AMBIENTAL DA ÁREA VERDE.

5.2 PERCEPÇÃO AMBIENTAL, TOPOFILIA E SABERES LOCAIS DA COMUNIDADE DA MICROBACIA EM RELAÇÃO À ÁREA VERDE........ 132

5.2.1 PERFIL DAS PESSOAS ENTREVISTADAS

5.2.2 PERCEPÇÃO AMBIENTAL E TOPOFILIA DA COMUNIDADE DA MICROBACIA EM RELAÇÃO À ÁREA VERDE. 
5.2.3 SÍNTESE DA PERCEPÇÃO E SABERES LOCAIS DA COMUNIDADE EM RELAÇÃO À ÁREA VERDE.

5.3 PERCEPÇÃO AMBIENTAL DE ESTUDANTES DO ENSINO MÉDIO DE TRÊS ESCOLAS ESTADUAIS INSERIDAS NA MICROBACIA DO CÓRREGO DA ÁGUA QUENTE EM RELAÇÃO À ÁREA VERDE DA MICROBACIA.

5.3.1 PERFIL DAS(OS) PARTICIPANTES

5.3.2 PERCEPÇÃO AMBIENTAL E TOPOFILIA DAS(OS) ESTUDANTES EM RELAÇÃO À ÁREA VERDE.

5.3.2.1.TOPOFILIA E TOPOFOBIA DAS(OS) ESTUDANTES EM RELAÇÃO À ÁREA VERDE DA MICROBACIA

5.3.3 VISITA À ÁREA VERDE DA MICROBACIA DO CÓRREGO DA ÁGUA QUENTE COM ESTUDANTES E PROFESSORES DA EE ORLANDO PEREZ.

5.3.4 INTERVENCÃO EDUCATIVA NAS ESCOLAS EE ORLANDO PEREZ E EE MARIA RAMOS

5.3.5 SÍNTESE DA PERCEPÇÃO AMBIENTAL E SABERES DAS(OS) ESTUDANTES EM RELAÇÃO À ÁREA VERDE DA MICROBACIA...........

6 SÍNTESE DAS RELAÇÕES ENTRE A PERCEPÇÃO $\mathbf{E}$ A CARACTERIZAÇÃO AMBIENTAIS E SUA CONTRIBUIÇẪO PARA A EDUCAÇÃO AMBIENTAL.

7 A PRÁXIS: A MOTIVAÇÃO PARA A PARTICIPACAO POLÍTICA A PARTIR DE PROJETOS PARTICIPATIVOS DE EDUCAÇÃO AMBIENTAL

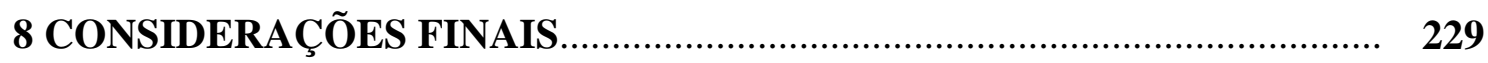

9 PERSPECTIVAS FUTURAS................................................................ 232

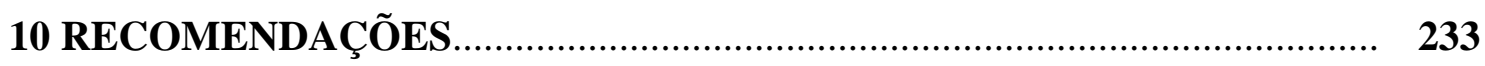

11 REFERÊNCIAS BIBLIOGRÁFICAS........................................................... 234 


\section{APRESENTAÇÃO}

Conheci a Microbacia do Córrego da Água Quente - MCAQ (São Carlos, SP) em 1998, ao fazer um registro fotográfico que compôs um trabalho intitulado "Impactos Ambientais na cidade de São Carlos" apresentado em um curso de Educação Ambiental (EA) oferecido pela Oficina Cultural de São Carlos. Fiquei surpresa ao conhecer o remanescente de vegetação natural inserido em uma grande extensão da microbacia, e perplexa ao observar a exclusão social em que vivia e vive grande parte da população ali residente. Os problemas sociais abrangiam desde a infra-estrutura precária de alguns bairros até problemas aparentemente conseqüentes dos impactos ambientais existentes na própria área verde, ocupada em alguns trechos de maneira irregular.

Em 1999, juntamente com uma equipe multidisciplinar e algumas(uns) estudantes do Ensino Médio, realizei uma pesquisa sobre a qualidade de alguns dos corpos d'água da área verde, em um trecho próximo ao bairro Jardim Gonzaga. Nesta pesquisa, que resultou na Monografia apresentada ao Curso de Especialização em Educação Ambiental do Centro de Recursos Hídricos e Ecologia Aplicada (CRHEA USP), tivemos oportunidade de adentrar a área verde e conhecer melhor suas belezas naturais e os impactos a que estava exposta. Também percebemos em conversas com algumas pessoas residentes na microbacia, quão diversificadas eram suas percepções em relação a esse ecossistema belo e ameaçado. Ficou o desejo de voltar à área para produzir mais dados que revelassem a necessidade de sua recuperação e manutenção e que pudessem contribuir para a inserção da comunidade local nesse processo.

Ao verificar que existem poucos estudos sobre a Microbacia do Córrego da Água Quente e que esta bacia possui uma área verde com grande potencial para a realização de pesquisas e projetos de Educação Ambiental, pela exuberância de sua paisagem e pela riqueza de sua biodiversidade, escolhi esse local para o desenvolvimento da pesquisa de doutorado.

Inicio a reflexão teórica fazendo uma análise das bases da Educação que nortearam essa pesquisa e intervenção educativa, cuja principal referência é Paulo Freire. Em seguida comento sobre a contribuição do estudo da Percepção Ambiental co-relacionado às pesquisas e intervenções em Educação Ambiental e ao Planejamento Urbano na perspectiva de Bacias Hidrográficas. 
Em relação aos termos utilizados no corpo do texto, escolhi utilizar a palavra "ambiental" em vez de "socioambiental", por entender que o ambiente tem amplo significado, ou seja, que já abrange o conjunto das interações biológicas, físicas, químicas e sociais (políticas, econômicas, estéticas, filosóficas, éticas, etc) entre todas as formas de vida e os elementos abióticos, incluindo, é claro, as relações entre seres humanos e destes com os demais elementos da biosfera.

Quando me refiro à sustentabilidade ou manejo sustentável de um ecossistema, parto da idéia de que ser sustentável significa respeitar e garantir o direito à vida com dignidade para todas as formas de vida, e também o cuidado e a manutenção para com os componentes abióticos, de modo a garantir o equilíbrio dinâmico desse ecossistema.

A presente pesquisa consistiu no levantamento da situação ambiental de uma área verde inserida na Microbacia do Córrego da Água Quente e da análise das relações estabelecidas pela comunidade local com esse ecossistema, e foi desenvolvida nas seguintes etapas:

1 - Estudo da percepção ambiental da população da microbacia em relação à área verde, com ênfase na topofilia e no conhecimento dos componentes e dos impactos existentes nesse ecossistema. Esta etapa envolveu dois públicos:

- a comunidade (40 pessoas de quatro bairros diferentes, sendo 10 pessoas residentes em cada bairro);

- estudantes de Ensino Médio de três escolas estaduais inseridas na microbacia;

2 - Caracterização ambiental preliminar da área verde da microbacia, incluindo:

- análise da qualidade dos corpos d'água (Córrego da Água Quente e algumas de suas nascentes);

- levantamento da vegetação com ênfase nas espécies medicinais;

- levantamento da fauna com ênfase na avifauna;

3 - Atividades de intervenção educativa com estudantes de três escolas inseridas na microbacia para disponibilização dos dados obtidos nas etapas anteriores visando:

- a informação e a sensibilização do público para a situação ambiental da área verde da microbacia e as relações desse ecossistema com a qualidade ambiental da microbacia; 
- a reflexão sobre a importância da participação da comunidade residente na microbacia em decisões e ações relacionadas ao manejo da área verde;

- o levantamento de sugestões para a elaboração de uma proposta participativa de manejo sustentável da área verde.

Espero que este trabalho possa enfatizar a importância das pesquisas e intervenções em Educação Ambiental baseadas na percepção ambiental, nos saberes locais e na perspectiva de bacia hidrográfica, e possa estimular as(os) professoras(es), minhas(meus) companheiras(os) de profissão/missão, a acreditar em seu papel de Educadoras(es) Ambientais. 


\title{
1 INTRODUÇÃO
}

\begin{abstract}
O que nos parece indiscutível é que, se pretendemos a libertação dos homens e mulheres não podemos começar por aliená-los ou mantê-los alienados. A libertação autêntica, que é a humanização em processo, não é uma coisa que se deposita nos seres humanos ${ }^{1}$. Não é uma palavra a mais, oca, mitificante. É práxis, que implica a ação e a reflexão do ser humano sobre o mundo para transformá-lo. (FREIRE, 1987)
\end{abstract}

Pela coerência entre seu discurso e suas ações, pela sua história de vida como cidadão e como educador, pela sua dedicação especial às classes populares e pela sua postura ética e política perante a vida e particularmente perante a educação, escolhemos Paulo Freire como nossa principal referência teórica para as reflexões sobre a Educação que acreditamos transformadora e que norteia nossas pesquisas e intervenções em Educação Ambiental (EA).

Vários anos da vida de Paulo Freire foram dedicados a um método de alfabetização que, além de ensinar a "leitura da palavra", também possibilitasse a "leitura do mundo", ou seja, o surgimento da consciência crítica voltada à construção da própria história e da história do mundo.

Freire experienciou seu método de alfabetização nos chamados "círculos de cultura”, que consistiam em grupos de pessoas refletindo e dialogando, com o auxílio de um(a) mediador(a), sobre elementos de sua realidade, e relacionando-os com as noções de cultura e de saber popular. Nesses encontros, as pessoas tinham oportunidade de se descobrir como seres dotados de cultura, capazes de modificar a natureza e a sociedade e, portanto, de alterar o rumo de sua história, passando a atuar como sujeitos.

\section{SOBRE O TERMO EDUCAÇÃO AMBIENTAL}

Quando falo em educação como intervenção me refiro tanto à que aspira a mudanças radicais na sociedade, no campo da economia, das relações humanas, da propriedade, do direito ao trabalho, à terra, à educação, à saúde, quanto à que, pelo contrário, reacionariamente pretende imobilizar a História e manter a ordem injusta. (FREIRE, 1998)

\footnotetext{
${ }^{1}$ Quando Paulo Freire escreveu Pedagogia do Oprimido, muitas cartas de mulheres foram enviadas a ele, ressaltando a importância do livro, mas criticando a linguagem machista, uma vez que ele se referia ao ser humano como "homem" em seus escritos. A partir de 1970, Freire passou a se referir sempre à mulher e ao homem, ou ao ser humano.

Por essa razão, todas as vezes que citamos os escritos de Freire anteriores a 1970, tomamos a liberdade de incluir o gênero feminino no texto, por entender, como Freire, que a mudança de linguagem também faz parte do processo de transformação da sociedade.
} 
Assim como afirma Paulo Freire a respeito da Educação de modo global, também a EA (que entendemos ser parte da primeira) nunca é neutra. Do mesmo modo que pode ser um instrumento de transformação da sociedade, de busca da sustentabilidade real que garante o direito à vida com dignidade para todos os seres humanos e para todas as formas de vida, a EA também pode contribuir para a consolidação do sistema de dominação e degradação do planeta e da opressão da minoria sobre a grande maioria da população humana.

Carvalho (2004) argumenta que a EA pode estar alicerçada em posicionamentos político-pedagógicos muito diferentes, tornando-se necessário situar o ambiente conceitual e político que fundamenta o projeto educativo. Quando esse projeto tende a contribuir para transformar a sociedade, a EA se encontra com o pensamento crítico dentro do campo educativo. A educação crítica tem suas raízes nos ideais democráticos e emancipatórios do pensamento crítico aplicado à educação.

Tozoni-Reis (2004), ao estudar a percepção de professoras(es) acerca da relação ser humano-natureza, da educação e da EA, identificou três abordagens. A primeira delas centra o processo educativo na individualidade humana, que apesar de resgatar a dimensão pessoal e afetiva do ser humano, ignora a experiência coletiva dos indivíduos em sociedades. A segunda compreende uma abordagem cognitivista que enfatiza a importância do conhecimento e as formas educativas de sua apropriação, em que a idéia fundamental é a educação como um processo de construção e reconstrução do conhecimento, medida pelas atividades mentais do indivíduo. Essa abordagem - que no Brasil tem grande contribuição da teoria construtivista de Piaget - evidencia o sujeito cognoscente, desvalorizando a inserção deste no processo histórico. Em contrapartida com essas duas abordagens, a autora observou uma terceira abordagem, baseada na chamada pedagogia crítica. Essa terceira abordagem, a qual consideramos mais coerente com nossa concepção de EA, defende que a educação é intencional, histórica e instrumento de transformação social.

Segundo Carvalho (op. cit.), o projeto político pedagógico de uma EA que se pretende transformadora tem uma especificidade: compreender as relações sociedadenatureza e intervir sobre os problemas e conflitos ambientais, contribuindo para uma mudança de valores e atitudes, ou seja, para a formação de indivíduos e grupos sociais aptos a identificar, problematizar e agir em relação às questões ambientais, tendo como horizonte uma ética preocupada com a justiça ambiental. Essa ética ambiental que 
ressignifica o cuidado para com a natureza e para com o outro humano, define as decisões sociais e reorienta os estilos de vida coletivos e individuais.

Para Boff (1999), as palavras estão grávidas de significados existenciais, e o autor revela que a palavra "cuidado" deriva do latim cura (ou coera), que expressa a atitude de cuidado, de desvelo, de preocupação e de inquietação pelo ser amado ou estimado. O autor conta que outros estudiosos derivam cuidado de cogitare-cogitatus, que tem o mesmo sentido de cura: cogitar, pensar, colocar atenção, mostrar interesse, revelar uma atitude de desvelo e de preocupação.

Pelo cuidado, nossa relação com a natureza e com o Outro não é do tipo sujeito-objeto, mas sujeito-sujeito. Este modo de ser-no-mundo, na forma de cuidado, permite ao ser humano viver a experiência fundamental do valor. Não do valor utilitarista, mas do valor intrínseco às coisas. A partir desse valor substantivo, todos nos sentimos ligados e religados uns com os outros. (BOFF, op. cit.)

Toda prática de EA que se omite de seu papel de suscitar esse sentido de cuidado para com todos os seres, aliado à reflexão crítica sobre as questões ambientais no contexto social e histórico, incentiva a continuidade da situação atual de desigualdade social e de desequilíbrio ecológico. Por outro lado, somente a EA com o intuito de romper com as estruturas de opressão da sociedade atual, é capaz de verdadeiramente educar um indivíduo ou grupo. Por essa razão consideramos desnecessário o acréscimo de uma nova palavra ao termo Educação Ambiental, que por si só nos parece completo e capaz de representar a única EA em que acreditamos e que tentamos promover. Portanto, durante esse texto decidimos utilizar apenas e suficientemente o termo Educação Ambiental.

Ao analisarmos toda a prática de Paulo Freire, chamada por ele de práxis ${ }^{2}$ sob o olhar da Educação Ambiental, inúmeras são as contribuições que podemos salientar, sendo que apenas as mais evidentes serão comentadas a seguir. Para ser transformadora, a Educação Ambiental deve ser dialógica, participativa, contextualizada, politizante e emancipatória.

\footnotetext{
2 Práxis significa ação com reflexão "A práxis é reflexão e ação dos homens e mulheres sobre o mundo para transformá-lo. Sem ela, é impossível a superação da contradição opressor-oprimido". (Freire, 1987)
} 


\subsection{EDUCAÇÃO AMBIENTAL: Construindo um paradigma para a participação democrática}

EDUCAÇÃO AMBIENTAL DIALÓGICA

Através do diálogo é possível conhecer os mitos - algumas vezes negativos e que podem influenciar a vida das pessoas - e permitir que estas se reconheçam determinadas, para que possam, a partir da reflexão individual e coletiva (diálogo), ter maior consciência e passar a ser apenas condicionadas, que é um estado de maior autonomia.

Como afirmou Paulo Freire, para ser superado, suplantado, o senso comum jamais pode ser descartado. Deve ser inicialmente valorizado como o ponto de partida para se chegar, através da reflexão, ao saber mais próximo do real, e finalmente ao saber crítico. Assim, o saber tradicional, ainda que baseado no senso comum, deve ser considerado e trabalhado, sendo que muitas vezes constitui o início, um importante complemento, ou mesmo o elemento principal da prática em EA. Considerar o direito do outro a expressar sua palavra ainda que inicialmente baseada no senso comum é o primeiro passo para o surgimento do diálogo.

Quando o dialogar inicia-se nos primeiros contatos entre educador(a) e educando(a), abre caminho para a instauração de um clima de confiança, que legitima e enriquece o próprio diálogo no decorrer do processo educativo.

\footnotetext{
Nosso papel como educadores não é falar ao povo sobre a nossa visão de mundo, ou tentar impô-la a ele, mas dialogar com ele sobre a sua e a nossa. Temos de estar convencidos de que a sua visão de mundo, que se manifesta nas várias formas de sua ação, reflete a sua situação no mundo em que se constitui. (FREIRE, 1987)
}

No momento em que o(a) educador(a) silencia para ouvir as outras pessoas, descobre como e por onde iniciar o trabalho de Educação Ambiental com aquele público, além de ter a oportunidade de repensar sua própria visão da realidade, comparando-a com a visão das outras pessoas. Incitar o diálogo entre os(as) participantes do processo de Educação Ambiental é contribuir para que aprendam a 
respeitar e valorizar as concepções e opiniões dos outros, a refletir sobre e a defender sua própria opinião, enfim, a pensar democraticamente.

Os homens e mulheres se fazem na palavra, no trabalho, na ação-reflexão. (...) Dizer a palavra verdadeira que é trabalho, é práxis, é transformar o mundo, não é privilégio de algumas pessoas, mas direito de todas as pessoas. Precisamente por isso, ninguém pode dizer a palavra sozinho, ou dizê-la para os outros, num ato de prescrição, com o qual rouba a palavra aos demais. $\mathrm{O}$ diálogo é o encontro dos seres humanos, mediatizados pelo mundo, para pronunciá-lo, não se esgotando, portanto, na relação eu-tu. (...) Não há diálogo, porém, se não há um profundo amor ao mundo e aos seres humanos. Não é possível a pronúncia do mundo, que é um ato de criação e recriação, se não há amor que a infunda. (...) Sendo fundamento do diálogo, o amor é, também, diálogo. (...) Não há, por outro lado, diálogo, se não há humildade. A pronúncia do mundo, com que as pessoas o recriam permanentemente, não pode ser um ato arrogante. O diálogo, como encontro dos seres humanos para a tarefa comum de saber agir, se rompe, se seus pólos (ou um deles) perdem a humildade. (...) Não há também diálogo, se não há uma intensa fé na pessoa humana. Fé no seu poder de fazer e de refazer. De criar e recriar. Fé na sua vocação de ser mais, que não é privilégio de alguns eleitos, mas direito de todos e todas.(...)

Ao fundar-se no amor, na humildade, na fé no ser humano, o diálogo se faz uma relação horizontal, em que a confiança de um pólo no outro é conseqüência óbvia. Seria uma contradição se, amoroso, humilde e cheio de fé, o diálogo não provocasse este clima de confiança entre seus sujeitos. (...) A confiança implica o testemunho que um sujeito dá aos outros de suas reais e concretas intenções. Não pode existir, se a palavra, descaracterizada, não coincide com os atos. Dizer uma coisa e fazer outra, não levando a palavra a sério, não pode ser estímulo à confiança. (FREIRE, 1987)

Freire (1998) enfatiza a importância do testemunho na prática educativa. Obviamente, esta é uma característica fundamental da Educação Ambiental baseada no diálogo, pois é a ação que legitima as palavras, que as mantém vivas, que as torna motivadoras, e que mostra às(aos) educandas(os) que o pensar certo é pré-requisito para o fazer certo, e que o fazer certo é possível.

De acordo com Oliveira (2002), a Educação Ambiental é um processo de construção de conhecimento que engloba o fazer educacional nas dimensões conceitual, procedimental e/ou atitudinal. Além dos conteúdos conceituais, portanto, através dos conteúdos procedimentais busca-se o desenvolvimento de técnicas e instrumentos para promover a participação efetiva dos sujeitos envolvidos na ação educativa. Nos conteúdos atitudinais vale mais o testemunho de uma experiência vivida em busca de uma nova relação com o ambiente, do que apenas o falar sobre as questões ambientais. Nessa dimensão a coerência entre discurso e prática vem à tona e é considerada um ponto chave na relação entre as(os) aprendizes e a(o) educador(a). 


\begin{abstract}
A desconsideração pela formação integral do ser humano fortalece a maneira autoritária de falar de cima para baixo. Nesse caso, falar a, que na perspectiva democrática é um possível momento do falar com, não ocorre" (...) No processo da fala e da escuta a disciplina do silêncio a ser assumido com rigor a seu tempo pelos sujeitos que falam e escutam é fundamental para a comunicação dialógica. (FREIRE, 1998)
\end{abstract}

Ao educador ou educadora, é necessário valorizar o saber de experiência feito dos grupos populares, a partir do qual fazem a leitura do mundo, do seu contexto e do contexto maior do qual seu contexto é parte. E desafiar tais grupos a pensarem sua história social, para que reconheçam em que posição se encontram (a de oprimidos ou de opressores) e de quem é realmente a responsabilidade pela situação de opressão, de modo que não sejam fatalistas, mas acreditem na possibilidade de mudança.

\title{
EDUCAÇÃO AMBIENTAL PARTICIPATIVA
}

$\mathrm{A}(\mathrm{o})$ educadora(or) deve estar advertida(o) do poder do discurso ideológico, que pode matar as ideologias, sem que se perceba a natureza ideológica do discurso que fala de sua morte. O discurso ideológico nos ameaça de anestesiar a mente, de confundir a curiosidade, de distorcer a percepção dos fatos, das coisas, dos acontecimentos. (FREIRE, 1998)

Dois importantes aspectos para que o resultado da prática em Educação Ambiental seja duradouro (ou permanente) são o seu caráter participativo e emancipatório. Um dos passos mais importantes e complexos em um trabalho de EA é suscitar na comunidade o desejo de participação, visto que em nosso país existe uma cultura bastante arraigada que, através do assistencialismo, estimula o comodismo.

Nos quatro bairros periféricos onde foi desenvolvida esta pesquisa observa-se um histórico comodismo por parte da maioria da população fundamentado em políticas públicas assistencialistas, que somente a partir da gestão municipal passada (2000-2003) começaram a ser combatidas com alguns projetos desenvolvidos pela prefeitura municipal que incentivam a participação de lideranças comunitárias. Essa experiência de participação ocorreu, por exemplo, no projeto de reurbanização dos bairros Jardim Gonzaga e Monte Carlo, financiado pelo BID (Banco Interamericano de Desenvolvimento), cujas obras foram fiscalizadas por uma comissão de moradoras(es). 
Além do assistencialismo, muitas vezes é disseminada a idéia de que somente especialistas têm a capacidade de sugerir e tomar decisões a respeito das questões ambientais, perdendo-se a riqueza da experiência daquelas(es) que passam suas vidas em um determinado local.

Não podemos escutar, sem um mínimo de reação crítica, um discurso no qual se afirma que os profissionais ou técnicos já sabem o que a população quer e do que precisa, e por isso perguntar a ela (dialogar com ela) seria uma perda de tempo. Nesse trabalho, essa afirmação foi encontrada no discurso dos sujeitos participantes, entre jovens estudantes, o que denota o sentimento de auto-exclusão, pois confirma que parte da população já incorporou a idéia de que não tem o direito de participar das decisões sobre seu espaço, ou seja, está privada do direito de ter voz, de optar.

$\mathrm{O}$ indivíduo somente sente-se motivado a participar quando se identifica com a questão ambiental, quando compreende a relação desta com sua vida e se vê como um importante ator capaz de influenciar e alterar uma determinada situação. Nesse enfoque, Sé (1999) e Gonzaga (2003) demonstraram que a EA escolar, quando pautada no pleno envolvimento e participação da comunidade escolar (que em suas pesquisas incluía crianças e jovens), contribui grandemente para a formação integral da(o) educanda(o), indo além da consciência ambiental, também para a noção de organização e mobilização que constituem a participação política.

Somente quando acredita em seu poder de transformação da realidade, o indivíduo sente-se co-responsável por essa mudança. Embora esse sentimento de empoderamento ${ }^{3}$ seja individual, raramente é construído individualmente, por alguém que se encontra isolado. $\mathrm{O}$ trabalho em equipe fomenta idéias mais diversificadas, enriquece as reflexões que favorecem a conscientização ${ }^{4}$ e aumenta as chances de concretização das ações necessárias à conservação do ambiente.

Paulo Freire defendia o trabalho coletivo, incentivando o exercício da solidariedade de equipe, para a formação da organização coletiva, sem perder de vista a riqueza da individualidade de cada educanda(o), e para buscar coletivamente saídas para problemas que surgissem a cada dia em seu quotidiano.

\footnotetext{
${ }^{3} \mathrm{Na}$ literatura, essa expressão é mais comumente encontrada em inglês (empowerment), e se refere ao indivíduo ou grupo que acredita em seu poder de influência na transformação de uma realidade.

${ }^{4}$ Entendemos que a conscientização, apesar de ser um processo individual, é grandemente influenciada pela reflexão do grupo.
} 
Encaminharemos o nosso agir educativo no sentido da consciência do grupo e não no da ênfase exclusiva do indivíduo. Sentimento grupal que nos é lamentavelmente ausente. As condições histórico-culturais em que nos formamos, nos levaram a esta posição individualista. Impossibilitaram a criação do ser humano solidarista, só recentemente emergindo das novas condições culturais em que vivemos, mas indeciso nessa solidariedade e necessitando por isso mesmo, de educação fortemente endereçada neste sentido. De educação que deve desvestir-se de todo ranço, de todo estímulo a esta culturológica marca individualista. Que dinamize, ao contrário, o espírito comunitário. (FREIRE, 1959)

Para Guimarães (2004), um processo educativo de caráter participativo tem o papel de fomentar a auto-estima de educandas(os)-educadoras(es) e a confiança na potencialidade transformadora da ação pedagógica articulada, que transita das ciências naturais às ciências humanas e sociais, da filosofia à religião, da arte ao saber popular, em busca dos diferentes saberes.

Um saber necessário à prática educativa é ter a coragem de abrir-se ao outro, compreendendo que a disponibilidade para ouvir e aprender com o outro, enriquece a ambos. É única a contribuição que as pessoas que vivem em uma determinada realidade, que a sentem em seu cotidiano, são capazes de oferecer para transformação dessa realidade. "Abrir-se à realidade do outro é aderir totalmente a seu direito de ser" (FREIRE, 1998).

\section{EDUCAÇÃO AMBIENTAL CONTEXTUALIZADA}

Este centralismo que envolve todo nosso agir educativo, é antes uma posição política. É uma atitude enraizada em nossas matrizes culturais. É a ele que se deve, em grande parte, a inorganicidade de nossa educação. E isto porque é do centro que se ditam as normas, distanciadas assim das realidades locais e regionais a que se devem aplicar. (FREIRE, 1959)

De acordo com Freire, a prática educativa deve partir dos problemas reais de cada comunidade, de modo que os educandos possam se identificar com o contexto estudado. Um grupo interessar-se-á por uma questão ambiental quando entender suas relações, suas causas e efeitos, e quais as possibilidades de reversão da situação ambiental apresentada. 
O ser humano precisa conhecer a realidade em que atua, o sistema de forças que enfrenta, para conhecer o seu 'viável histórico'. Em outras palavras, para conhecer o que pode ser feito, em um momento dado, pois que se faz o que se pode e não o que se gostaria de fazer (FREIRE e GUIMAR ̃̂ES, 1982)

Nesse sentido, a prática educativa deve buscar a formação do sujeito enquanto ser individual e social, historicamente situado, ou seja, não se reduz a uma intervenção centrada exclusivamente no indivíduo - como se a mudança social se desse apenas pela soma das mudanças individuais - nem tampouco se dirige a coletivos abstratos diluindo a subjetividade num sistema social genérico e despersonalizado, cuja mudança acarretaria automaticamente na mudança das concepções e atitudes individuais (CARVALHO, 2004). A EA contextualizada e crítica pressupõe que indivíduo e sociedade só fazem sentido se pensados em relação, pois a história das sociedades humanas não é previamente determinada, mas resultante de processos (inclusive de processos educativos) construídos e transformados por sujeitos históricos, que norteiam suas ações individuais e coletivas a partir de suas posturas políticas e visões de mundo. Dessa forma, acreditamos que a EA é parte inerente do movimento social, ao mesmo tempo que tem o papel de questioná-lo.

A linguagem utilizada pela(o) educador(a) é um dos principais instrumentos que garantem que um processo educativo seja contextualizado, pois garante a compreensão da prática e dos conflitos a serem enfrentados pela comunidade. Para se introduzir a comunidade no processo educativo, este deve iniciar-se com a compreensão pela(o) educador(a) da linguagem e dos símbolos característicos da comunidade envolvida, e de seus principais anseios relacionados à questão abordada, de modo que possa incorporálos na prática educativa.

\section{EDUCAÇÃO AMBIENTAL POLITIZANTE}

A educação é uma intervenção no mundo, e como tal implica tanto o esforço de reprodução da ideologia dominante, quanto o seu desmascaramento, constituindo-se dialética e contraditória (...) A educação nunca é neutra, e não sendo neutra, educar(-se) é sempre um ato político. A natureza política da educação se explica na educabilidade do ser humano, que se funde na sua natureza inacabada e da qual se tornou consciente. Inacabado e consciente de seu inacabamento, necessariamente o ser humano se faria um ser educável, ético, um ser de opção, de decisão. Um ser ligado a interesses segundo os quais pode manter-se fiel à eticidade ou transgredi-la. (FREIRE, 1998) 
Em termos conceituais, a Educação é essencialmente política, pois qualquer espaço em que nos formamos e moldamos as características objetivas que nos cercam, de acordo com Demo (1988), é um espaço político.

Como toda Educação é um ato político, tanto do(a) educador(a) como da(o) educanda(o), assim o é toda forma de Educação Ambiental. Ao “fazer" Educação Ambiental o indivíduo pode tanto libertar(-se) como alienar(-se). Todavia, a Educação Ambiental que aqui caracterizamos como politizante, trata-se daquela cujo papel é o de colocar o indivíduo frente a si mesmo para que se conscientize de que somos seres inacabados, e por isso podemos ser abertos a aprender, a crescer, a ser mais (vocação ontológica do ser humano). Heidegger (1989) entende por ontológico tudo aquilo que entra na definição essencial do ser humano e estrutura sua prática.

A Educação Ambiental também oferece ao ser humano a chance de contemplar o mundo com uma visão crítica, sendo capaz de fazer a "leitura do mundo" sabendo-se integrado a ele, compreendendo a realidade e pensando soluções para os problemas coletivos.

Quando a Educação Ambiental refere-se apenas aos aspectos ecológicos das questões ambientais excluindo o ser humano, ou quando enfatiza os impactos ambientais e seus efeitos sem analisar as causas (suas raízes), dificilmente contribui para modificar a estrutura responsável pela origem dos problemas ambientais. E não se pode afirmar que esse tipo de Educação Ambiental não é política, porque toda Educação é um ato político. E aquela que não parte da complexidade das questões ambientais, que não questiona as atuais relações de poder, os padrões de produção, de distribuição e consumo dos bens, e de descarte dos resíduos resultantes, na verdade defende a política do continuísmo.

A educação oferecida deve ser uma educação para a decisão, para a responsabilidade social e política. (...) Uma educação para o desenvolvimento e para a democracia haveria de ser a que oferecesse ao(à) educando(a) instrumentos com que resistisse aos poderes do "desenraizamento". (...) Uma educação que possibilitasse ao ser humano a discussão corajosa de sua problemática. De sua inserção nesta problemática. Que o advertisse dos perigos de seu tempo, para que consciente deles, ganhasse força e coragem de lutar, ao invés de ser levado e arrastado à perdição de seu próprio $e u$, submetido às prescrições alheias. Educação que o colocasse em diálogo constante com o outro. Que o predispusesse a constantes revisões, à análise crítica de seus achados. Que levasse o ser humano a uma nova postura diante dos problemas de seu tempo e de seu espaço. (FREIRE, 1989) 


\title{
EDUCAÇÃO AMBIENTAL EMANCIPATÓRIA
}

\begin{abstract}
Uma das maiores tragédias do homem e da mulher modernos está em que hoje são dominados pela força dos mitos e comandados pela publicidade organizada, ideológica ou não, e por isso vêm renunciando cada vez, sem o saber, à sua capacidade de decidir. Vêm sendo expulsos da órbita das decisões. As tarefas de seu tempo não são captadas pelas pessoas simples, mas a elas apresentadas por uma elite que as interpreta e lhas entrega em forma de receita, de prescrição a ser seguida. Ajustam-se ao mandado de autoridades anônimas e adota um eu que não lhes pertence. (FREIRE, 1989)
\end{abstract}

Para que o ser humano rompa com esse processo de alienação que leva à sua exclusão das esferas de decisões que dizem respeito ao seu ambiente e à sua qualidade de vida, e que o obriga a ajustar-se a estas decisões, a Educação Ambiental tem o papel de ensinar a pensar certo ${ }^{5}$, de despertar uma atitude crítica, de promover a reflexão de mãos dadas com a ação (práxis), e de promover o encorajamento para que o ser humano volte a integrar-se, superando o simples ajustamento ou acomodação, e a assumir a luta pela recuperação e conservação de seu ambiente, que está intimamente ligada à garantia de sua dignidade como pessoa.

O que importa, realmente, ao ajudar-se o ser humano é ajudá-lo a ajudar-se. É fazê-lo agente de sua própria recuperação. É, repitamos, pô-lo numa postura conscientemente crítica diante de seus problemas. O assistencialismo, ao contrário, é uma forma de ação que rouba ao homem condições à consecução de uma das necessidades fundamentais de sua alma, a responsabilidade. (FREIRE, 1989)

Para Carvalho (2004), a tematização dos conflitos e da justiça ambientais é o território político onde a EA que se pretende emancipatória encontra espaço para engajar-se na construção de valores éticos e na produção de uma cultura ambiental que vai influir na maneira como os grupos sociais se relacionam, e dispõem dos bens ambientais. Enfim, Santos (2000) afirma que reinventar a emancipação é conceber uma globalização contra-hegemônica — chamada por Casaldáliga (2002) de mundialização ou outra mundialidade - a partir de redes locais-globais que lutem contra a exclusão, a exploração e a opressão produzidas pela globalização neoliberal. Concretamente, tais

\footnotetext{
5 "Ensinar a pensar certo não é uma experiência em que ele - o pensar certo - é tomado em si mesmo e dele se fala ou uma prática que puramente se descreve, mas algo que se vive enquanto dele se fala com a força do testemunho. Pensar certo implica a existência de sujeitos que pensam mediados por objeto ou objetos sobre que incide o próprio pensar dos sujeitos. Pensar certo não é "que-fazer" de quem se isola, mas um ato comunicante. Não há por isso mesmo pensar sem entendimento e o entendimento, do ponto de vista do pensar certo, não é transferido, mas co-participado.” (Paulo Freire, 1998)
} 
lutas objetivam criar alternativas ao capitalismo neoliberal através da criação ou fortalecimento de espaços de participação democrática e solidária e de novos modelos de produção e consumo que, no campo ambiental, penso que significa o surgimento de uma nova cultura ambiental.

Após essa reflexão, resumimos na figura 1 as características necessárias à EA transformadora, que esclarece a qual EA estamos nos referindo.

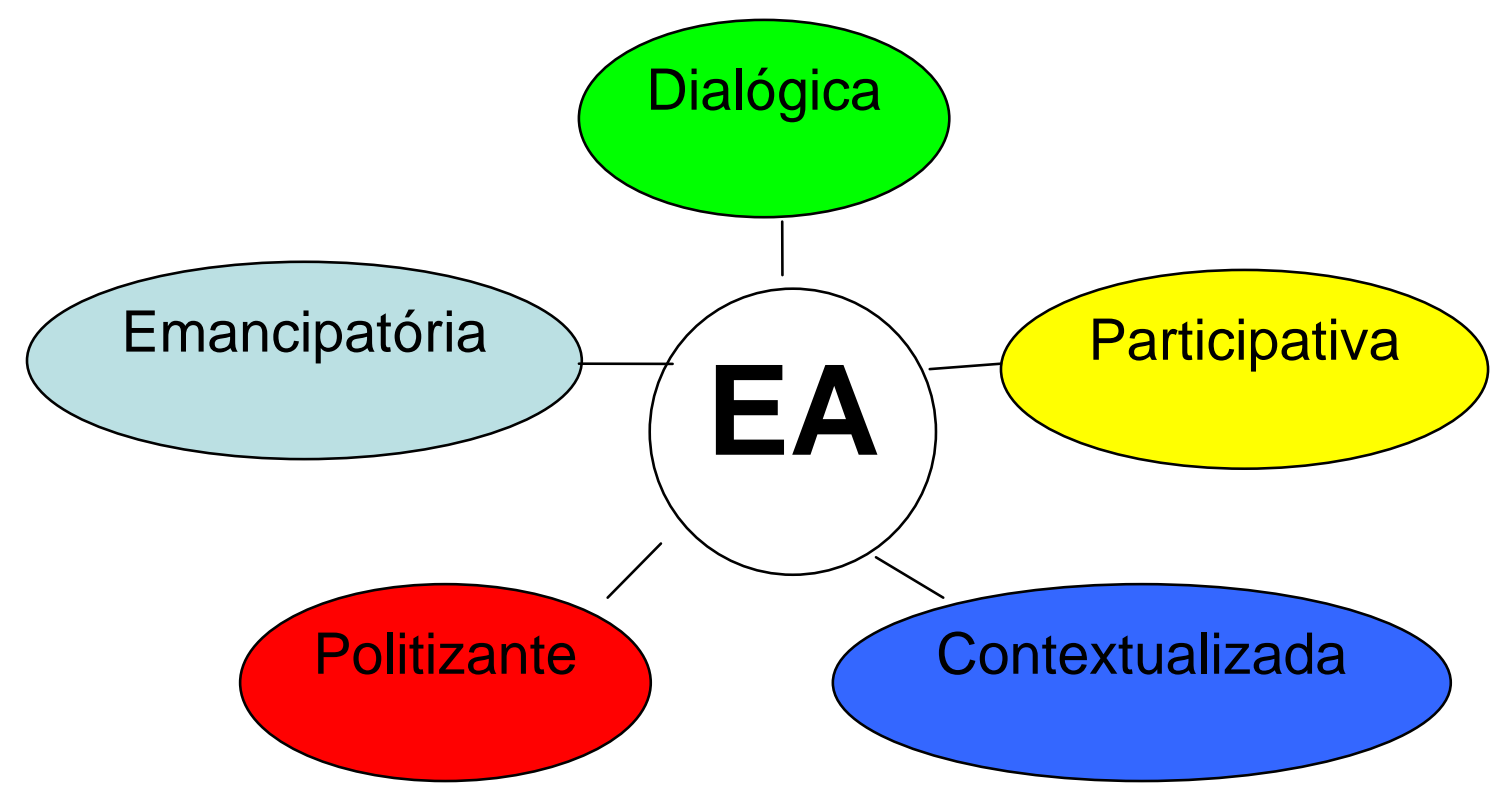

Figura 1: Características fundamentais da Educação Ambiental.

\subsection{EDUCAÇÃO AMBIENTAL E PESQUISA PARTICIPANTE}

Zuñiga (1982), citado por Gajardo (1999), reivindica para Paulo Freire o título de criador de um estilo alternativo de pesquisa e ação educativa, por sua prática baseada na concepção conscientizadora da educação, que se iniciou com camponeses no Chile e no Peru, incentivando a participação destes nos novos modelos de produção agrária na década de 60 .

Durante todas as etapas, procuramos esclarecer aos sujeitos a intenção desta pesquisa e a importância da participação de todas(os), tentando torná-la o mais participativa possível. 
A pesquisa participante surge no início dos anos oitenta, época em que vários países latino-americanos eram governados por regimes autoritários segundo modelos excludentes de desenvolvimento político e econômico. Nesse cenário, a pesquisa participante reconhece as implicações políticas e ideológicas de qualquer pesquisa ou intervenção social, e busca o desenvolvimento de ações de mobilização de grupos visando a transformação da realidade social (GAJARDO, op. cit.).

Quanto às metodologias participativas, a pesquisa participante busca promover a produção e a análise coletiva e crítica do conhecimento, rompendo com o monopólio do saber e da informação, para que o conhecimento torne-se patrimônio dos grupos populares. Procura também estabelecer relações entre os problemas individuais e coletivos, determinando suas causas e encontrando soluções coletivas (ROBOTTOM e HART,1993; FIEN,1993).

De acordo com a participação dos grupos populares em projetos de pesquisa participante, podem ser destacados cinco níveis: 1- participação a partir da devolução de informação; 2- participação a partir da coleta de dados; 3- participação em todo o processo sobre o tema proposto pelo cientista; 4- participação em todo o processo sobre um tema proposto pelo próprio grupo; 5- participação na pesquisa a partir da ação educativa (GAJARDO, 1999). Acreditamos que nessa pesquisa houve a participação da comunidade a partir da coleta de dados e das(os) estudantes em todo o processo a partir de um tema por nós proposto.

Muitas formas de pesquisa participante atuam como método de ação e de aprendizagem coletiva, visando a transformação do povo em sujeito político, que reivindica de maneira consciente e organizada uma presença ativa e de real importância na sociedade a que pertence (GAJARDO, op. cit.). Segundo a autora, a pesquisa participante também pode aparecer como um componente de processos de planejamento social que envolvem grupos ou comunidades, geralmente que vivem em condições de dominação e pobreza, como é o caso da maioria dos sujeitos dessa pesquisa.

Gajardo (op. cit.) também destaca alguns aspectos importantes nesse tipo de pesquisa, como os seguintes:

1) explicitação de uma intencionalidade política e uma opção de trabalho junto aos grupos mais marginalizados da sociedade;

2) integração de investigação, educação e participação social como momentos de um processo centrado na análise daquelas contradições que mostram com maior clareza os determinantes estruturais da realidade vivida e enfrentada como objeto de estudo; 
3) sustentação das atividades de investigação e ação educativa sobre uma base organizada de sorte que esta atividade não culmine em uma resposta de ordem teórica, mas na geração de propostas de ação expressadas em uma perspectiva de mudança social.

Ao refletir sobre pesquisa participante, Brandão (1999a) analisa o que significa participar, apontando três princípios básicos para que uma pesquisa possa ser considerada pesquisa participante:

a) a possibilidade lógica e política dos sujeitos populares serem os produtores diretos ou os participantes associados do próprio saber;

b) a determinação do uso e do destino político do saber produzido pela pesquisa, tenha ela tido ou não a participação dos sujeitos populares em todas as suas etapas;

c) a relação do pesquisador em seu trabalho com o povo que gera a necessidade da pesquisa, e na própria pesquisa que gera a necessidade de sua participação.

A qualidade da relação entre pesquisador(a) e pesquisada(o) são determinantes para que uma pesquisa em Educação Ambiental tenha bons resultados. Brandão (1999b) concorda que para que uma pesquisa de campo seja de qualidade, a estratégia e a técnica dependem tanto de pressupostos teóricos quanto da maneira como (a)o pesquisador(a) se coloca na pesquisa e através dela e, a partir daí, constitui simbolicamente o outro que investiga (BRANDÃO, op. cit.b, grifos do autor).

Quando a relação com o outro pesquisado se transforma em um compromisso, a relação obriga a que o pesquisador participe de sua vida e de sua história. Para esse tipo de pesquisa são utilizadas as técnicas de observação participante, entrevista livre e história de vida. $\mathrm{A}(\mathrm{O})$ pesquisador(a) descobre que a maneira espontânea de um(a) entrevistado(a) falar sobre qualquer assunto é através de sua pessoa, de sua história de vida, ou de um fragmento de relações entre a sua vida e aquilo a que responde (BRANDÃO, op.cit.b). Em vários momentos durante essa pesquisa apareceram fragmentos da vida das pessoas participantes, em que comparavam sua vida e seu lugar atual com lugares e experiências do passado, como modo de justificar suas opiniões e percepções.

$\mathrm{Na}$ pesquisa participante, com freqüência, o outro, sujeito vivo da pesquisa, torna-se o companheiro de um compromisso político de luta popular, o que obriga o pesquisador a repensar não só a posição de sua pesquisa, mas também de sua própria 
pessoa. (BRANDÃO, 1999b) O outro pesquisado, sujeito e razão da pesquisa, muitas vezes assume também o papel de educador, transmitindo ao pesquisador a história de um lugar — o seu lugar — inserida em sua história de vida.

Brandão alerta que a idéia de participação popular pode ser simplesmente um exercício de manipulação populista da elite detentora do poder sobre o povo. Por outro lado, pode representar ações de fortalecimento do poder popular, tornando-se a pesquisa participante um instrumento científico, pedagógico e político de participação nos trabalhos de produção do poder popular, uma vez que conhecimento pode ser sinônimo de poder e emancipação. Por isso é essencial se definir em nome de qual projeto político a pesquisa participante é colocada em ação nas comunidades populares. $\mathrm{O}$ autor conclui que não há modelos únicos de pesquisa participante. Ela é um instrumento dentro da ação popular, é ouvir as decisões e as necessidades da comunidade, e ser um mediador que coloca os instrumentos e o saber de sua profisssão a serviço da prática política popular na comunidade. Quando as pessoas do povo participam da pesquisa, há de ser porque de algum modo ela faz parte de seus projetos e de seus anseios (BRANDÃO, op. cit.b).

\subsection{A PRÁXIS EM EDUCAÇÃO AMBIENTAL}

A origem da compreensão sobre a necessidade urgente de se investir em processos de Educação Ambiental (EA) provavelmente baseou-se na percepção de algumas pessoas, em diferentes lugares do mundo, de que em muitas sociedades as relações humanas e do ser humano com os demais elementos do ambiente eram (e são) predatórias e insustentáveis, e precisavam (e precisam) ser aperfeiçoadas.

Os impactos ambientais no meio urbano resultam principalmente da precariedade dos serviços e da omissão do poder público, porém, muitas vezes são também reflexo do descuido e da omissão das(os) próprias(os) moradoras(es), comprometendo aspectos de interesse coletivo. A postura de conformismo e/ou de omissão da população são frutos principalmente da desinformação, da falta de consciência ambiental e da inexistência de práticas comunitárias baseadas na participação e no envolvimento das(os) cidadãs(ãos). 
Incentivar a participação dessas pessoas em todas as questões ambientais ${ }^{6}$ e mais especificamente nas relacionadas ao planejamento urbano para a manutenção ou recuperação da qualidade ambiental da cidade, é um importante papel da Educação Ambiental. Esse processo de envolvimento da comunidade deve contribuir para que esta se torne sensibilizada, bem informada, consciente de seu papel e de seu poder de mobilização e de intervenção na realidade, e motivada para agir.

Nesse sentido, a escola é um terreno fértil para a prática da Educação Ambiental, pois como instituição co-responsável pela formação integral das crianças e jovens, deve esclarecer a interdependência entre todos os elementos (bióticos e abióticos) de um ecossistema e promover o respeito e o cuidado para com o ambiente, além de motivar a participação responsável nas questões ambientais. Nesse contexto, a EA é um instrumento fundamental de incentivo ao desenvolvimento de uma nova cultura de direitos baseada na motivação e na co-participação da gestão ambiental das cidades e das bacias hidrográficas

De acordo com Leff (2001), para a realização de um planejamento e gestão ambiental integrados e democráticos, é necessário um diagnóstico ambiental participativo, que significa gerar, em um processo educativo juntamente com a população local, informações sobre o estado do meio ambiente e alternativas para o enfrentamento dos problemas ambientais. Esta dinâmica de gestão ambiental baseia-se na autonomia das populações e busca opções consideradas ao mesmo tempo sociais e tecnicamente viáveis e politicamente legítimas. Esse diagnóstico fundamenta-se na difusão de informações científicas sobre a complexidade dos sistemas ambientais, no registro e processamento de diferentes modalidades de conhecimento ecológico local, no exercício da mediação de conflitos resultantes do pluralismo de crenças e sistemas de valores sobre o patrimônio natural, e na escolha daquilo que seria desejável construir coletivamente no espaço local ou comunitário, respeitando a capacidade de suporte do sistema.

A Política Nacional do Meio Ambiente, definida pela Lei Federal n. 6.983/81, situa a EA como um dos princípios que garantem "a preservação, melhoria e recuperação da qualidade ambiental propícia à vida, visando assegurar no país

\footnotetext{
${ }^{6}$ Consideramos o ambiente em todos os seus aspectos - sociais, políticos, econômicos, estéticos, afetivos, biológicos, físicos, químicos, entre outros, e todos inter-relacionados e interdependentes) conforme comentado na apresentação deste trabalho.
} 
condições ao desenvolvimento socioeconômico, aos interesses da segurança nacional e à proteção da dignidade da vida humana" (Brasil, 1981).

A Política Nacional de Educação Ambiental, criada pela Lei Federal n. 9.795/99 (BRASIL, 1999), por sua vez, define a EA como "os processos por meio dos quais o indivíduo e a coletividade constroem valores sociais, conhecimentos, habilidades, atitudes e competências voltadas para a conservação do meio ambiente, bem de uso comum do povo, essencial à sadia qualidade de vida e sua sustentabilidade". Esta lei define também a EA não-formal ${ }^{7}$ como "ações e práticas educativas voltadas à sensibilização da coletividade sobre as questões ambientais e à sua organização e participação na defesa da qualidade do meio ambiente".

Seara-Filho (1992) entende que a educação é um processo pedagógico que deve orientar o indivíduo na expressão de suas potencialidades, e desenvolver na(o) educanda(o) sobretudo sua capacidade crítica, seu espírito de iniciativa e seu senso de responsabilidade. Segundo o autor, esses são também objetivos da EA.

Zeppone (1996), defende que a EA no Brasil deve ser tratada em caráter emergencial e de forma consciente, cuja prioridade é a construção de mentes mais sadias e convictas de sua participação na sociedade e no mundo exercendo, assim, um de seus direitos proclamados na Constituição Brasileira, que é viver em um ambiente ecologicamente equilibrado com uma digna qualidade de vida.

Para Reigota (1994), a EA deve ser uma educação política, que reivindica e prepara os cidadãos e cidadãs para exigir justiça social, cidadania nacional e planetária, auto-gestão e ética nas relações sociais e com a natureza.

A EA deve ser, acima de tudo, um ato político voltado para a transformação social, e buscar a solidariedade, a igualdade e o respeito às diferenças, a partir de práticas interativas e dialógicas (Jacobi, 1998). Um grande desafio da EA é ampliar a comunicação entre a população e o poder público, criando espaços para uma necessária articulação com os governos locais, e permitir a participação popular na tomada de decisões e na implementação de ações voltadas à proteção ambiental e à eqüidade social.

A amplitude e complexidade do problema ambiental implicam o desenvolvimento de técnicas e metodologias adequadas para um melhor conhecimento

\footnotetext{
${ }^{7}$ Apesar desse termo constar nas leis, entendemos que a EA pode ser formal ou não-formal em diferentes situações e com diversos públicos, e preferimos definir a tradicionalmente chamada de EA formal como EA escolar, e a chamada EA não-formal, como EA comunitária, EA empresarial, etc).
} 
dos ecossistemas, suas características e funções. Nas escolas, as reflexões sobre "Meio Ambiente" devem abranger todas as séries, para que esse Tema Transversal possa estar presente em todo o período de desenvolvimento da criança e da(o) jovem, consolidando a compreensão do papel individual e coletivo na conservação ambiental. Tundisi (2000) destaca ainda dois tópicos que auxiliam enormemente no controle da crise ambiental: o monitoramento ambiental com a criação de bancos de dados sobre um ecossistema e a educação ambiental abordando a bacia hidrográfica como unidade de estudo.

\subsection{PERCEPÇÃO AMBIENTAL}

A concepção de ambiente que exclui o ser humano, colocando-nos como elementos à parte, capazes de atuar como observadores ou modificadores externos do restante do ambiente, deixa de considerar, com o devido peso, o papel predominante desempenhado pela espécie humana sobre os demais elementos da biosfera (também sobre outros seres humanos) e nossa responsabilidade direta na conservação ou extinção dos ecossistemas com todas as suas formas de vida.

Por entender a importância decisiva de se considerar os complexos aspectos da mente humana que norteiam nossas relações com o ambiente do qual somos parte, escolhemos o estudo da percepção ambiental num esforço de compreender o que define a maneira como o ser humano se relaciona com seu entorno e o que concebe como qualidade ambiental e qualidade de vida.

Mediante a idéia de estudarmos a percepção ambiental de dois grupos de pessoas da Microbacia do Córrego da Água Quente (grupo de residentes próximos à área de vegetação natural e grupo de estudantes de três escolas inseridas na microbacia), procuramos conhecer as considerações de diversos autores(as) sobre percepção ambiental e destacar aquelas com as quais concordamos e nos baseamos neste estudo.

Del Rio (1999), Kuhnen (2001) e Tuan (1980) consideram a percepção como um processo mental de interação do indivíduo com o meio ambiente que ocorre através de dois tipos de mecanismos: mecanismos perceptivos propriamente ditos, dirigidos pelos estímulos externos e captados pelos cinco sentidos, com destaque para a visão; e os mecanismos cognitivos, que compreendem a contribuição da inteligência, incluindo motivações, humores, necessidades, conhecimentos prévios, valores, julgamentos e expectativas. Del Rio e Oliveira (1999) afirmam que "nem tudo o que envolve a 
inteligência passa pelos cinco sentidos". Porém, além dos processos sensorial e cognitivo da percepção, para Kuhnen (2001) o ato perceptivo também depende de componentes psicossociais que, juntamente com os demais, irão possibilitar a decodificação das informações e transformá-las em significados.

$\mathrm{Pol}^{8}$ et al. citado por Kuhnen (op. cit.) definem percepção ambiental como o "processo a partir do qual se organiza e interpreta a informação sensorial em unidades significativas para configurar um quadro coerente do entorno ou de uma parte dele".

Del Rio (1999) admite que as percepções são subjetivas para cada indivíduo, mas defende que existem recorrências comuns, tanto em relação às percepções e imagens, quanto às condutas. Assim, podem surgir expectativas compartilhadas pela população que, orientadas por políticas públicas que norteiem a ação, poderão gerar impactos positivos no desenvolvimento econômico e sociocultural de uma área e da sua comunidade. Tuan (1983) salienta ainda que a cultura pode influenciar a percepção e neste sentido poderíamos considerar que se a cultura de um grupo é constituída coletivamente, também este autor acredita na influência social sobre a percepção.

Kevin Lynch, em seu livro publicado em 1960 e traduzido em 1998, tem estudos sobre a paisagem urbana, nos quais define que os atributos do meio ambiente natural ou construído influenciam a percepção visual do indivíduo, formando imagens compartilhadas pela população (LYNCH, 1998).

De acordo com Santos et al. (1996), além da percepção individual, também existe a percepção social estudada por Saarinen em 1969 e por Schiff em 1973 (citados por Santos et al., op cit.). A percepção social refere-se à influência dos fatores social e cultural sobre a estruturação cognitiva do ser humano em seu ambiente físico e social. Esse tipo de percepção varia de acordo com as capacidades dos órgãos dos sentidos e depende também dos estímulos presentes, das histórias vividas e das atitudes dos indivíduos, que envolvem valores, necessidades, lembranças, humor, circunstâncias sociais e expectativas.

Para Castello (2001) a percepção do ser humano em relação ao ambiente pode ser um importante indicador de qualidade ambiental poucas vezes considerado, e Santos et al. (op. cit.) acreditam que o estudo da percepção nas relações ser humano-ambiente pode favorecer um uso mais sustentável dos recursos ambientais.

\footnotetext{
${ }^{8}$ POL et al. "Psicología ambiental y processos psicosociales." In: MORALES, J. F. (org). Psicología Social. Madrid: McGraw-Hill, 1999.
} 


\subsubsection{PERCEPÇÃO DA PAISAGEM}

O significado do conceito de paisagem ${ }^{9}$ está relacionado aos processos de cognição, afetividade, memória e criação de imagens que compõem o fenômeno da percepção, sempre influenciado pelas diversas conjunturas de ordem natural, social, econômica ou cultural (Guimarães, 2001).

De acordo com Machado (1988), não é possível falar de paisagens a não ser a partir de sua percepção pelo ser humano, uma vez que a paisagem não se separa da experiência e da vivência humana. A partir do contato com uma paisagem (objeto), através da percepção, o ser humano (observador) apreende essa paisagem e a avalia. E avaliar uma paisagem implica fenômeno perceptivo que não pode ser estudado como um evento isolado da vida cotidiana das pessoas, pois a percepção está sempre presente em toda e qualquer atividade humana. É, portanto, o ser humano quem percebe, contempla e vivencia as paisagens, atribuindo a elas significados e valores.

Segundo Macedo (1999), paisagem é a expressão morfológica das diferentes formas de ocupação e de transformação do ambiente em determinado tempo, e é vista como um produto da interferência humana e como um sistema que oferece respostas a essa interferência.

De modo simplificado, uma paisagem é definida como tudo aquilo que está ao alcance do olhar e à disposição do indivíduo, ou seja, um lugar onde o ser humano passa sua vida. Relph (1979) chega a dizer que "não há experiência ambiental que não seja uma experiência de paisagem", tamanha é a ligação entre os elementos da paisagem e o ser humano presente na paisagem direta ou indiretamente, que obviamente também representa um componente desta.

Portanto, entender o significado da paisagem para um indivíduo ou grupo através do estudo da percepção, contribui para compreender o sentimento e as atitudes das pessoas em relação aos lugares. Além disso, o estudo de percepção da paisagem fornece elementos importantes para a identificação dos graus de valorização do meio ambiente por um grupo e pode auxiliar em uma intervenção que melhore, quando necessário, a relação do grupo com a paisagem abordada.

\footnotetext{
${ }^{9}$ Etimologicamente, o vocábulo em português provém do francês paysage e apresenta na definição do lexicógrafo FERREIRA (1984, p.1018), conotações vinculadas à percepção espacial e à arte: "1. Espaço de terreno que se abrange num lance de vista. 2. Pintura, gravura ou desenho que representa uma paisagem natural ou urbana."
} 
De acordo com Guimarães (2001), a sociedade da época moderna via a natureza como paisagem, enquadrada como categoria estética e esta visão atravessou toda a história do pensamento ocidental.

As mudanças ocorridas nas sociedades ocidentais, urbano-industriais, ditas civilizadas ${ }^{10}$ rumo ao progresso, denotam a perda em várias dimensões da qualidade da vida em todas as suas formas. As áreas naturais que compõem a paisagem das cidades representam uma dessas dimensões, tendo sido sensivelmente modificadas pelas relações da sociedade com o ambiente natural.

Para acompanhar estas mudanças, o entendimento do termo paisagem também evoluiu como advertem Ratiu e Moser $^{11}$ (1996) citados por Kuhnen (2001). Todavia, ainda hoje, o termo paisagem urbana raramente faz referência aos conceitos de natureza ou natural. A paisagem ainda é freqüentemente vinculada ao caráter estético, especialmente presente na percepção da qualidade visual, na apreciação de panoramas. O valor estético de uma paisagem é composto por valores subjetivos e objetivos, as valorizações particulares ou as amplamente apreciadas e monetarizadas (KUHNEN, op. cit.).

A recente descoberta, por alguns grupos, da importância da paisagem e de certos modos de vida como fator de desenvolvimento econômico e social através do turismo, por exemplo, mostram o quanto a natureza é um elemento estruturante do desenvolvimento econômico das sociedades. Há cidades ou mesmo países que vivem, sobretudo, deste tipo de recurso e dependem em grande parte dos elementos naturais para assegurar uma economia estável (KUHNEN, op. cit.).

\subsubsection{PERCEPÇÃO E VALORIZAÇÃO DA PAISAGEM}

Para Lowenthal (1982), não é possível uma perfeita sintonia entre o mundo exterior e as nossas idéias sobre ele. A percepção e valorização de uma paisagem

\footnotetext{
${ }^{10}$ Sociedade civilizada, neste caso, representa a população que habita as cidades. Entendemos, entretanto, que nas cidades em geral, a população é composta por diferentes grupos sociais, dissociados em classes sociais com distintas oportunidades, interesses e privilégios, de modo que cada grupo, e mesmo as pessoas dentro de um mesmo grupo, relacionam-se de diversas maneiras com o ambiente, gerando impactos positivos ou negativos de espécies e proporções variadas.

${ }^{11}$ RATIU, E.; MOSER, G. (1996) Paysage et psychologie de l'environnement. Paris: Laboratoire de Psychologie de L'Environnement,
} 
dependem dos aspectos culturais e sociais de um grupo, mas também das variações de pensamento de cada indivíduo, pois a percepção vem sempre acompanhada de sentimento em relação a um lugar, e este sentir pode ser modificado ao longo do tempo de acordo com os acontecimentos. Um determinado lugar passa a ter um valor diferente quando é palco de um acontecimento significativo, ou quando recorda algo do passado que ficou particularmente registrado em nossa lembrança. Mesmo entre indivíduos pertencentes à mesma sociedade e à mesma cultura, podem-se encontrar diversas maneiras de perceber e relacionar-se com o ambiente, contemplando uma paisagem com olhar particular.

Em pesquisa realizada por Donald Meinig em 1979, citado por Cabral e Buss (2001) sobre valorização da paisagem, foram destacadas dez categorias: paisagem como natureza (destaca os elementos físicos e pouco considera a ação humana); paisagem como habitat (visão antropocêntrica em que a paisagem é considerada território para morada do ser humano); paisagem como sistema (visão de conjunto, em que não aparecem fatos isolados); paisagem como problema (onde se tende a identificá-la como algo a ser superado); paisagem como artefato (onde a paisagem é vista como o produto da ação humana); paisagem como riqueza (onde é atribuído valor monetário aos seus elementos); paisagem como ideologia (representa os símbolos de uma sociedade); paisagem como história (é um registro de experiências do passado); como lugar (possui valor associado à satisfação das necessidades) e paisagem como estética (é avaliada pelos aspectos artísticos e panorâmicos).

\footnotetext{
"A paisagem vivida preserva e transmite ao longo da história de vida de cada um de nós, os valores e percepções de nossos grupos culturais, cristalizando em si o tempo vivido, mediando relações de conivência entre processos que resgatam as experiências passadas visando a compreensão do presente, bem como armazenando referências para o devir" (GUIMARÃES, 2001).
}

Barbosa (1998) pensa a paisagem como mediação entre o mundo material e aquele da subjetividade humana, pois todas as características da paisagem (forma, cor, escala) são apreendidas pelo olhar humano e assumem diferentes significados de acordo com os diferentes olhares. 
Existe uma tendência natural de, a partir dos diferentes olhares, se desenvolver sentimentos de apreço e cuidado para com as paisagens consideradas belas, como pôde ser observado neste estudo em relação à área de vegetação nativa. Do mesmo modo, quando uma paisagem está associada a algum sentimento negativo, como medo, desconforto visual, olfativo ou auditivo, corre-se o risco dessa ser desvalorizada a ponto de perder a importância de existir. Para Relph (1979) os lugares são determinados por suas paisagens, mas também por nossos cuidados e responsabilidade, ou pelo nosso descaso para como eles.

Isso demonstra a importância de se compreender o valor atribuído à paisagem nos dias atuais visando a sua conservação, uma vez que a degradação ambiental vem se intensificando, principalmente nas áreas urbanas.

\subsubsection{PERTENCER AO ESPAÇO PARA TORNÁ-LO LUGAR}

O conceito de lugar

Segundo Relph (op. cit.) não existem limites precisos entre o significado de espaço, paisagem e lugar, nem a relação entre eles é constante: lugares têm paisagens, e paisagens e espaços têm lugares. E o "lugar" talvez seja o mais significativo, pois focaliza a "paisagem" e o "espaço" em torno das intenções e experiências humanas. É em relação aos lugares que desenvolvemos nossos sentimentos, positivos e negativos, e é onde vivemos e nos relacionamos com as outras formas de vida e também com outras pessoas, todas componentes desses lugares.

Para Tuan (1983), "lugar" pode ser qualquer objeto estável que capta nossa atenção, pois ao visualizar um panorama, existem pontos referenciais que atraem nosso olhar de modo particular. $O$ autor observa que os lugares são conhecidos emocionalmente, e não através do olho crítico ou da mente, e por isso um lugar pouco importante para um indivíduo pode possuir grande significado para outro. Este mesmo autor também admite que é possível descrever o lugar sem a utilização de conceitos espaciais, mas que o conceito de espaço depende dos objetos e lugares que definem esse espaço.

A realidade da existência humana se estabelece em um ou vários lugares que muitas vezes não escolhemos, que podem ser onde se está no presente, os lugares da 
infância, ou um ambiente que por alguma razão nos atrai (DARDEL ${ }^{12}, 1952$, citado por CABRAL e BUSS, 2001). Tuan (1983) por sua vez, esclarece que o lugar existe em escalas diferentes, que pode ser desde um objeto ou um símbolo específico, a pátria (cidade ou região) ou todo o planeta. Nessa pesquisa, um lugar que aparece com bastante significado para alguns participantes é o bairro, que é considerado por elas(es) parte de sua história (ou de suas vidas) e do qual sentem-se parte, e por isso dificilmente o deixariam. A área verde também denota lugar de grande significado para a maioria das(os) participantes reportando-as(os) a lugares do passado e despertando sentimentos de nostalgia e contentamento.

Augè (1994) diferencia "espaço" de "lugar", ao afirmar que, enquanto um lugar pode ser definido como histórico, relacional e identitário, um espaço não é nem identitário, nem relacional, nem histórico, caracterizando um "não-lugar". Portanto, pode existir o "lugar" e o "não-lugar". Quando um espaço ou paisagem é considerado por uma pessoa ou grupo como um não-lugar, ocorre sentimento de indiferença que pode ser o caminho para o não-cuidado ou para a degradação.

Para Guimarães (2001), a experiência com o ambiente nos leva à reflexão sobre a existência de espaços e lugares, pois as paisagens que os compõem estão carregadas de significados, nos envolvem e ancoram nossas recordações. Esses significados podem ainda ser renovados a cada nova experiência com nossos espaços e lugares. Concordando com a visão da autora, de que os significados podem ser dinamicamente modificados, um dos objetivos desse trabalho foi proporcionar às(aos) participantes novas experiências ambientais positivas, através da reflexão e do contato físico com a paisagem estudada.

Guimarães (2004) considera o "espaço físico" essencial para a recordação da história vivida e, quando este representa o substrato das experiências de vida dos seres humanos, é transformado em "lugar" e recebe uma identidade especial que pode variar para diferentes grupos ou entre indivíduos de um mesmo grupo. Neste estudo foi possível identificar lugares específicos da microbacia caracterizados com nomes próprios, sendo que os nomes mais freqüentes foram "vale" e "buracão", e estes denotam características físicas da paisagem mais próxima de cada grupo entrevistado.

\footnotetext{
${ }^{12}$ DARDEL, Eric. L'Homme et la terre: nature de la realité géographique. Paris: Presses Universitaires de France, 1952.
} 


\subsubsection{SENTIMENTO DE PERTENÇA: IDENTIFICAR-SE COM O LUGAR}

Ao se pensar no principal componente natural da Microbacia do Córrego da Água Quente, que é o remanescente de vegetação natural (que estabelecemos chamar de área verde), há que se considerar que, além de todo o seu papel ecológico como ecossistema natural, essa paisagem constitui um espaço social de grande significado para a população do entorno, principalmente no que diz respeito ao lazer e à apreciação estética via percepção visual. Neste sentido, as interações sociais exercidas neste e com este espaço físico são muito importantes quando se pensa em manejo, cuidado e conservação.

A abordagem do conceito de apropriação permite compreender a intencionalidade de certas práticas sociais e as modalidades de relação que o ser humano estabelece com o espaço físico e social, tanto em relação aos lugares quanto aos outros indivíduos (KUHNEN, 2001). Para a autora, o processo de apropriação e identificação através da manipulação de um espaço está associado à sua significação e valorização, sendo que a impossibilidade de apropriação e conseqüentemente a ausência do sentimento de pertença, poderiam levar à depredação. Isso nos leva a crer que a possibilidade de desfrute estimula o cuidado e a proteção de um espaço, passando este a significar um lugar.

Os espaços e seus símbolos são organizados e valorados de acordo com a cultura e o contexto social de cada grupo, que interage com eles e lhes atribui significado. Essas interações levam a um processo de apropriação do espaço, que passa a ser reconhecido como lugar e com o qual há identificação. É a partir do sentimento de apropriação que um lugar pode oferecer a sensação de prazer e de bem estar (PROSHANSKY, 1982), ou de mal estar, e que a pessoa sente-se pertencente ou não àquele lugar. Quando um indivíduo ou grupo fica impossibilitado de se apropriar de um lugar, sente que este não lhe pertence (LAUWE, 1976, citado por KUHNEN, op. cit.) e o atual sistema muitas vezes restringe o direito sobre os espaços para uma minoria privilegiada, o que compromete o sentido de apropriação do espaço pela maioria.

É importante observar a origem da apropriação de um espaço e o seu enraizamento, que é um processo que se dá em longo prazo, a medida que a pessoa ou grupo convive, reflete, compreende a importância, se identifica e transforma o espaço em lugar. Esse processo de apropriação é construído a partir das mudanças ocorridas no próprio indivíduo ou grupo e, no momento em que este começa a se identificar com o 
espaço-agora-lugar sente o desejo-responsabilidade e a capacidade-propriedade para dele cuidar.

Para que um ecossistema seja protegido, há que se buscar meios para compatibilizar os interesses da população local - que na área estudada, é a população residente em toda a microbacia, e principalmente no entorno da área de vegetação natural - com os objetivos que justificam o manejo da área verde. Enquanto as(os) moradoras(es) estiverem excluídos dos processos de decisão e de gestão sobre esse espaço com o qual convivem, ou se forem impedidas(os) de usufruir de modo equilibrado do local, a degradação e ou a ausência de participação na manutenção da área persistirão e poderão se acentuar. Daí a idéia de iniciar com elas(es) um processo educativo visando o manejo participativo da área estudada, para que possam adquirir o sentido de apropriação [cuidar do que é delas(es)].

\subsection{TOPOFILIA}

“Os lugares estão em nossa memória e identidade”. (TUAN, 1980)

Outro aspecto importante no estudo das relações ser humano-ambiente é a compreensão dos sentimentos que cada indivíduo desenvolve em relação a uma paisagem ou território, com todos os seus componentes. Acreditamos que são estes sentimentos, frutos da experiência com os mais diversos elementos da própria área, e possivelmente influenciados também por experiências passadas em outros lugares, os responsáveis por definir as atitudes positivas ou negativas em relação ao ambiente.

De acordo com Guimarães (2001) para entender a paisagem vivida, além da análise da percepção de suas estruturas espaciais, ecológicas, institucionais, culturais, entre outras, é necessário compreender as relações pessoa/paisagem, que envolvem o imaginário, o mítico, o simbólico, que são delineados pelos sentimentos.

Tuan (op. cit.) utiliza o termo topofilia, que pretende expressar a compreensão e aspirações do ser humano em termos de qualidade ambiental. Eric Dardel (1952) citado por Cabral e Buss (2001), considera que as relações ser humano-ambiente podem ser positivas (experiências topofílicas) ou negativas (experiências topofóbicas). A topofilia significa uma interação agradável, prazerosa, enquanto a topofobia indica sentimentos 
de repulsão, aversão, medo, e ambas dependem das características do ambiente em si e dos valores e condutas das pessoas que com ele convivem.

Para Milton Santos (1986), a paisagem é resultante do processo histórico. A natureza está, para ele, sempre em relação às mudanças e às necessidades da sociedade, que deve ter a natureza como um espaço de contemplação direta e um espaço de reprodução da vida, e não uma mercadoria trabalhada por outra mercadoria (o ser humano coisificado).

Segundo Tuan (1983), os contatos com o ambiente são estabelecidos através dos cinco sentidos que se completam e da inteligência que organiza as informações, e a partir daí podem surgir intensos sentimentos de topofilia ou topofobia em relação às paisagens. E o mesmo autor, em 1980, afirmou que as relações afetivas com o ambiente podem levar a diferentes graus de envolvimento e promover nos indivíduos mudanças de atitude em relação ao ambiente.

Castello (1999) afirma que a água é um dos símbolos mais importantes da natureza no âmbito da percepção sensorial, porque é capaz de produzir experiências envolvendo os cinco sentidos. Em seu trabalho, Lynch (1998) destaca a preferência sobre as paisagens que contêm água.

Para Ramadier (1997) citado por Castello (2001), cada indivíduo é um sujeito ativo que interpreta o meio com o qual interage, e constrói seu ambiente. As experiências vividas são utilizadas como suporte para suas interpretações e os objetivos e intenções auxiliam na construção de seu ambiente. Acreditamos que a interação de cada ser humano com os elementos do ambiente, ao mesmo tempo que altera, ainda que minimamente esse ambiente, também provoca modificações no significado destes para o ser humano, que refletem na alteração das relações topofílicas. Neste sentido, a água é considerada um elemento bastante significativo da paisagem, geralmente atrelado a recordações marcantes. Essas recordações variam das mais agradáveis, como o contato com a água limpa e fresca, até situações extremamente negativas envolvendo esse elemento, como a poluição hídrica, as enchentes ou a escassez.

Cunha (2000), citada por Marin (2003) afirma que a água "está na natureza e na cultura, está nos mitos e na história", e faz referência à água como espaço de contemplação, enfatizando sua beleza e contentamento que trazem "consolo psíquico". Neste trabalho procuramos dar ênfase às relações de percepção e topofilia em relação à água, uma vez que a área de estudo é uma microbacia composta por várias nascentes e constitui, inclusive, importante área de recarga do aqüífero Guarani. 


\subsection{BACIA HIDROGRÁFICA E PERCEPÇÃO AMBIENTAL: A ABORDAGEM INTEGRADORA NO PROCESSO EDUCATIVO}

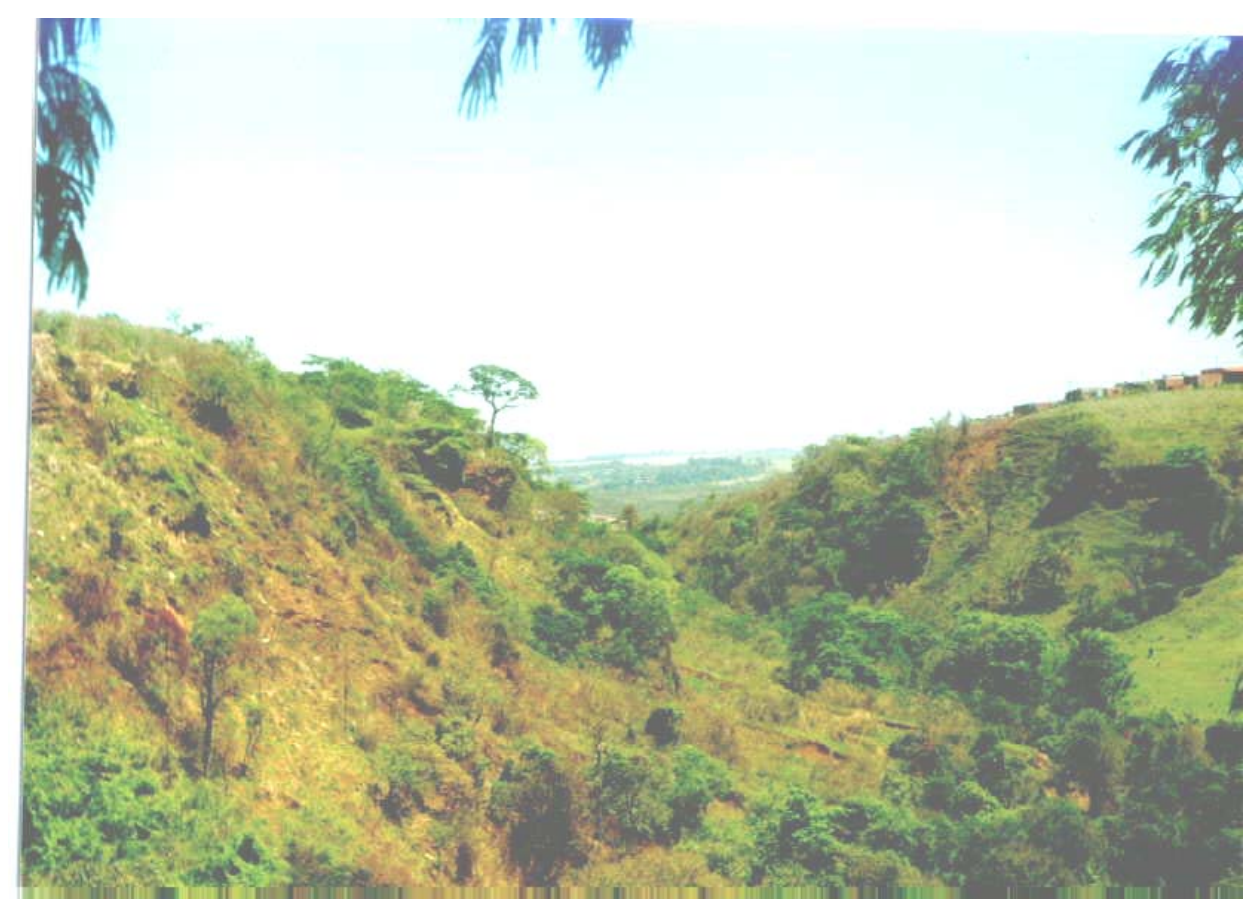

Figura 2: Vista panorâmica da Microbacia do Córrego da Água Quente.

Dentre as(os) autoras(es) que trabalham com Educação Ambiental sob a perspectiva da bacia hidrográfica estão Marin (2003), Kunieda (2003), Gonzaga (2003), Oliveira (2002), Ferreira (2002), Matheus e Sé (2002), Sé (1999), Di Giovanni (1999), Ravagnani (1999) e Raffaini e Corigliano (1998), e todas(os) as(os) integrantes do Curso de Especialização em Educação Ambiental do Centro de Recursos Hídricos e Ecologia Aplicada da USP, desde 1995, quando esse curso teve início (A Figura 2 representa a microbacia hidrográfica onde foi desenvolvida esta pesquisa).

O uso da bacia hidrográfica como unidade de planejamento nas pesquisas e na gestão dos corpos d'água originou-se da percepção de que os ecossistemas aquáticos são essencialmente abertos, trocam energia e matéria entre si e com os ecossistemas terrestres adjacentes, e sofrem alterações de diferentes tipos, em virtude dos usos do solo e das atividades antropogênicas nele desenvolvidas (ROCHA et al., 2000).

Vários autores apresentam definições para o conceito de bacia hidrográfica (STRASKRABA e TUNDISI, 2000; BAUER, 1988; ART, 2001, entre outros), mas o conceito que consideramos mais abrangente e que mais se aproxima da heterogeneidade 
inerente a uma bacia hidrográfica é de Rocha et al. (2000), que definem a bacia hidrográfica como um sistema biofísico e socioeconômico, integrado e interdependente, que contempla áreas habitacionais, industriais, de serviços, formações vegetais, nascentes, córregos e riachos, enfim, variados habitats e unidades da paisagem. Seus limites são estabelecidos topograficamente pela linha que une os pontos de maior altitude que definem os divisores de água entre uma bacia e outra adjacente.

Calijuri e Oliveira (2000) afirmam que o uso disciplinado das bacias hidrográficas está atrelado a uma política de conservação dos recursos hídricos que inclua o reflorestamento e a proteção da vegetação natural, a conservação do solo, o controle das enchentes e a conservação da fauna, além do monitoramento permanente dos corpos d'água. E que a bacia hidrográfica é formada por um conjunto de microbacias, facilitando o manejo da qualidade da água a medida que forem enfocadas as microbacias. Por ser uma unidade natural com características pedológicas, geológicas, geomorfológicas, climatológicas e biológicas específicas, a análise conjunta destes diversos componentes é necessária para uma avaliação mais completa das atividades antrópicas.

A Lei Federal $n^{0}$ 9.433/97 instituiu a Política Nacional de Recursos Hídricos, que caracteriza a Bacia Hidrográfica como "unidade de planejamento, gerenciamento e conservação, garantindo o uso e reconhecimento da água como bem de domínio público, finito e vulnerável, dotado de valor econômico, e que em caso de escassez, deve ter uso prioritário para consumo humano e dessedentação de animais". (BRASIL, 1997). Nesse sentido, a EA pode contribuir para o esclarecimento da população em relação à quantidade de água realmente disponível no planeta e em cada região ${ }^{13}$, e ao papel da sociedade na recuperação e conservação da qualidade e quantidade desse bem finito e essencial à vida. Essa mesma lei criou o Sistema Nacional de Recursos Hídricos (SNRH) que, entre outras instâncias, é composto pelos Comitês de Bacias Hidrográficas dos quais participam os municípios, visando uma gestão descentralizada e participativa dos corpos d'água por bacia hidrográfica.

Portanto, as abordagens "bacia hidrográfica" e "qualidade da água", permitem compor um sistema que indica mecanismos de funcionamento das bacias hidrográficas e seus efeitos na qualidade de vida (MATHEUS \& SÉ, 2002).

\footnotetext{
${ }^{13}$ Esclarecer sobre a quantidade de água realmente disponível significa desmitificar a idéia disseminada de que, se a água é um recurso natural renovável e o Brasil possui cerca de 13\% da água doce do planeta, não ocorrerá escassez, quando na verdade, esta já é a realidade de várias regiões brasileiras.
} 
De acordo com Pires (1995), a Limnologia considera que as características dos corpos d'água refletem a dinâmica da bacia hidrográfica, espelhando na qualidade e quantidade de água, as atividades humanas existentes na mesma. Todavia, são poucos e recentes os estudos sobre bacias hidrográficas que consideram, além da percepção e do levantamento de dados científicos de especialistas e técnicos, também a percepção da comunidade que vive na bacia estudada.

Como as cidades estão inseridas em uma ou mais bacias hidrográficas, a interpretação da bacia hidrográfica como unidade de estudo é essencial para o planejamento ambiental urbano, uma vez que este deve considerar todas as características ambientais da(s) bacia(s) na(s) qual(is) a cidade está inserida. Nesse sentido, a percepção das pessoas que construíram sua história em cada microbacia da cidade e puderam acompanhar todas as modificações de origem natural e/ou antrópica ocorridas no local, pode ser um fator de grande contribuição. Esse saber feito de experiência de vida pode possibilitar que estes indivíduos reconstituam a história do local, comparem a qualidade ambiental atual com a de outras épocas e relatem com detalhes os processos de degradação responsáveis pelos impactos ambientais atuais. Destarte, a comunidade pode representar um rico banco de dados sobre o local estudado e atuar nos moldes de um monitoramento ambiental do local baseado nas percepções individuais e coletivas.

Em relação à EA escolar, a bacia hidrográfica na qual a escola está inserida é uma importante "sala de aula natural", e as aulas de campo são essenciais para a compreensão pelas(os) educandas(os) da relação dos corpos hídricos com os demais elementos da bacia (áreas de vegetação natural, agricultura, habitações, indústrias, entre outros) e de sua importância para a manutenção da vida. Além de possibilitar o contato com esse ecossistema através dos cinco sentidos e a partir de suas experiências passadas, as(os) estudantes, ao dialogar com as(os) residentes no local têm oportunidade de conhecer o histórico da bacia e a percepção das(os) moradoras(es), que contribuirão para que construam ou modifiquem sua própria percepção em relação a esse ecossistema.

Os estudos de Percepção Ambiental, assim como a Educação Ambiental permeiam um considerável número de disciplinas, porque as pesquisas em percepção ambiental abordam situações muito heterogêneas, que variam desde análises de ambientes em micro-escala (a percepção daquilo que permite a uma pessoa se orientar 
dentro de um edifício, por exemplo), até uma escala nacional e, mesmo, global (CASTELLO, 2001).

Concordamos com este autor quando ele também afirma que a percepção ambiental é um caminho para habilitar as(os) atuais educadoras(es) para estabelecerem e transmitirem às(aos) educandas(os) reflexões sobre as estratégias que se oferecem à sociedade contemporânea no estabelecimento de relações mutuamente benéficas com seu ambiente. A compreensão da antropização da natureza em uma região - a ocupação de um território natural pelo ser humano, transformando-o numa paisagem cultural pode encontrar boas explicações a partir dos estudos de percepção ambiental.

Assim, a percepção tem dupla função didática, pois pode transformar as(os) educadoras(es) em educandas(os), ensinando-lhes a compreender o ambiente ao revelarlhes os valores através dos quais aquelas(es) que eles irão educar percebem o seu ambiente. E as(os) educandas(os), por sua vez, podem aprender sobre alternativas e técnicas a adotar nas relações com seu ambiente, ao lhes serem apresentados os ensinamentos e as experiências específicas das(os) educadoras(es).

É dentro dessa lógica que na EA podemos desenvolver um aprendizado coletivo -atuando como educador(a)-educanda(o) e educanda(o)-educador(a) - para o ambiente sob o ângulo da Percepção Ambiental. Observar o uso e a ocupação de um espaço pode nos fazer entender os fenômenos ambientais que estão em pauta naquele ambiente e que explicam sua configuração, para com isto educar-nos quanto à seleção de alternativas mais adequadas para um planejamento fundamentado no cuidado para com todas as formas de vida e no respeito à cultura e aos saberes locais, e que envolva a comunidade nesse processo.

\subsection{CARACTERIZAÇÃO DA ÁREA DE ESTUDO}

\subsubsection{A CIDADE DE SÃO CARLOS: QUADRO SÓCIOECONÔMICO E AMBIENTAL}

A área estudada foi a Microbacia do Córrego da Água Quente, inserida na parte sul da área urbana do município de São Carlos, Estado de São Paulo, e para melhor compreensão das características da área escolhida serão apresentadas algumas considerações sobre o município (cuja localização está ilustrada na Figura 3). 
Localizado na região centro-norte do estado de São Paulo (SP) a cerca de 235 km da capital, o município de São Carlos situa-se entre os paralelos $21^{\circ} 57^{\prime}$ e $22^{\circ} 06^{\prime}$ de latitude Sul e entre os meridianos $47^{\circ} 50^{\prime}$ e $48^{\circ} 05^{\prime}$ de longitude Oeste (IBGE citado por SÉ, 1992). Possui área aproximada de 113.700 ha $\left(1.137 \mathrm{Km}^{2}\right)$ e perímetro de $231.200 \mathrm{~m}$.

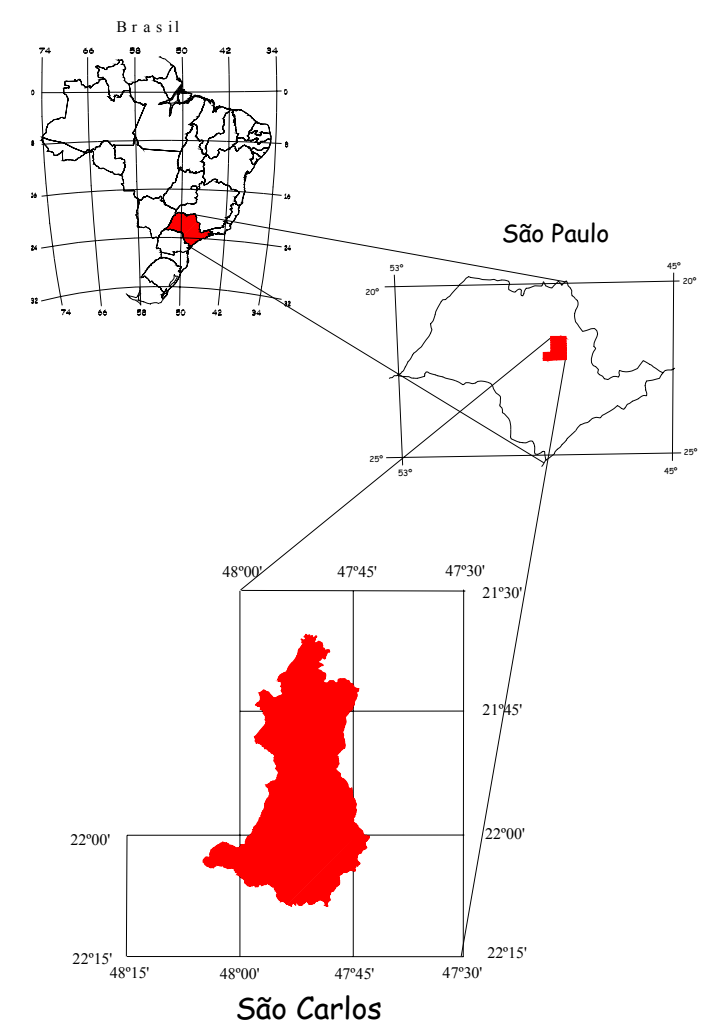

Figura 3: Localização de São Carlos - Estado de São Paulo. Fonte: MURO, 2000.

O município situa-se em uma região economicamente privilegiada, dentro de um raio de aproximadamente $100 \mathrm{Km}$ de algumas das cidades mais importantes do Estado, como Campinas e Ribeirão Preto. Faz divisa com onze municípios, a saber: ao NorteNordeste, Luiz Antônio, a Leste fica o município de Descalvado, a Sudeste, Analândia, ao Sul limita-se com Itirapina e Brotas, a Sudoeste, Ribeirão Bonito, a Oeste estão Ibaté e Araraquara, e finalmente a Noroeste situam-se Américo Brasiliense, Santa Lúcia e Rincão.

Possui extensa rede hidrográfica - 20 corpos d'água e 700 nascentes somando cerca de $1.023 \mathrm{~km}$ de cursos d'água em seu território incluindo os perenes e os intermitentes, sem considerar aqueles que fazem limite com os municípios lindeiros. $\mathrm{O}$ 
Rio Mogi-Guaçu, situado ao Norte, percorre $36.050 \mathrm{~m}$ do município, estabelecendo a divisa com o município de Luiz Antônio (TÓRO-TONISSI e TONISSI, 2002).

A altimetria no município varia de $515 \mathrm{~m}$, na área de alagamento próxima ao Rio Mogi-Guaçu, ao Norte, na porção que pertence à Bacia do Ribeirão das Guabirobas, até 1.000 m, na porção Sudeste do município, na Bacia do Ribeirão do Feijão, apresentando uma variação de 485 m (LORANDI, 1985).

As informações sobre a pedologia foram extraídas das cartas do Levantamento Pedológico Semidetalhado do Estado de São Paulo, na escala 1:100.000, em que os solos foram agrupados em 6 grandes classes: os Latossolos, subdivididos em Latossolo Vermelho-Amarelo, Latossolo Vermelho-Escuro e Latossolo Roxo; os solos Podzólicos Vermelho-Amarelo; a Terra Roxa Estruturada; as Areias Quartzosas Profundas; os solos Litólicos e os solos Hidromórficos (OLIVEIRA e PRADO, 1984).

O clima de São Carlos, de acordo com a classificação de Köepen, pertence ao tipo Cwb, considerado um Clima Tropical de Altitude. Caracteriza-se por um verão úmido e um inveno seco. O período seco abrange os meses de abril a setembro, sendo o mês de agosto o responsável pelos menores índices de precipitação. O período de outubro a março caracteriza a estação chuvosa, com os maiores índices de precipitação ocorrendo nos meses de dezembro e janeiro. As médias anuais de precipitação variam entre $1.200 \mathrm{~mm}$ e $1.500 \mathrm{~mm}$. No período seco, a média de precipitação é de apenas 279 mm de chuva, correspondendo a $18,5 \%$ do total anual e a umidade atmosférica a apenas $20,5 \%$ do total anual. Mattos (1982) verificou que a temperatura média do mês mais quente é inferior a $22^{\circ} \mathrm{C}$. O mesmo autor, em um trabalho desenvolvido na Bacia do Rio Jacaré-Guaçú em 1984, apresenta o balanço hídrico da região de São Carlos, onde se pode perceber que a água armazenada representa em média 1/4 a $1 / 3$ da precipitação mensal, o que caracteriza a região como de recarga da Formação Botucatu (MATTOS, 1982 ; OLIVEIRA E PRADO, 1984 e SANTOS, 1993).

Segundo o censo do IBGE (2000), naquele ano o município possuía uma população de 192.998 habitantes, e a estimativa para 2005 era de 210.840 habitantes. (PREFEITURA MUNICIPAL DE SÃO CARLOS, 2000).

Historicamente, o município apresentou um rápido crescimento populacional com concentração na área urbana. Nas décadas de 60 e 70, quando surgiram vários bairros da microbacia estudada, como o Jardim Gonzaga e o Monte Carlo, São Carlos já apresentava um índice de componente migratório de 3,37\%, quando o do Estado de São 
Paulo era de 3,45\%. Em 1970, 89\% dos habitantes do município já residiam na área urbana, e em 2000, essa porcentagem se elevou para $95 \%$ da população vivendo na cidade (IBGE, op. cit.).

Em relação à oferta de emprego, entre 1989 e 1992, o município assistiu a uma redução nos setores da indústria e serviços, com alguma recuperação em 1995, e nova queda do emprego industrial em 1996, devido ao aumento de exigências educacionais para os empregados dos setores comercial e de serviços, de modo que somente a classe de trabalhadores com nível médio de escolaridade (atualmente classificado entre a $5^{\text {a }}$ série do Ensino Fundamental e a $2^{\mathrm{a}}$ série do Ensino Médio) conseguissem emprego, gerando uma taxa de emprego negativa para os demais.

O município localiza-se em duas grandes bacias hidrográficas: 2/3 do território pertencem à Bacia do Rio Mogi-Guaçu, e a parte restante compõe a Bacia do Rio Jacaré-Guaçu - estando inseridos nesta última quase todo o perímetro urbano e a Microbacia do Córrego da Água Quente ao Sul - na divisa entre São Carlos e os municípios de Itirapina e Brotas.

De acordo com a Lei Estadual n $n^{\circ} 7.663$, de dezembro de 1991, o município faz parte da $6^{\circ}$ Unidade de Gerenciamento de Recursos Hídricos (UGRH) do Estado de São Paulo, estando localizado na $13^{\mathrm{a}}$ Bacia denominada Tietê/Jacaré, e participa deste comitê de bacia criado em 1995. A Figura 4 mostra a divisão do Estado em 22 bacias hidrográficas (DAEE, 2005). Atualmente, integra também a $9^{\text {a }}$ Unidade de Gerenciamento de Bacia Hidrográfica do Estado de São Paulo, através do Comitê de Bacia Hidrográfica do Mogi-Guaçu, porque parte de seu território pertence a esta outra bacia que abrange a maior parte de sua área (aproximadamente 60\%) (ESPÍNDOLA, 2000; LIMA, 2003).

Quanto à hidrografia, o município foi dividido em 10 principais microbacias, que podem ser vistas na figura 5, de acordo com informações obtidas no mapeamento baseado nas Cartas Topográficas do Instituto Brasileiro de Geografia e Estatística (IBGE, 2002), na escala 1:50.000, em ordem decrescente de tamanho: a microbacia do ribeirão dos Negros, com 30.173 ha; a do Rio do Monjolinho, com 20.610 ha, considerada especialmente importante por abranger integralmente a zona urbana e, em nosso caso, a Microbacia do Córrego da Água Quente; a do ribeirão das Araras, com 20.044 ha; a do ribeirão do Feijão, com 12.560 ha; a do Rio Jacaré-Guaçú, com 8.216 ha; a do ribeirão das Cabaceiras, com 6.960 ha; a do ribeirão das Guabirobas, com 5.722 
ha; a do Rio Mogi-Guaçú, com 4.167 ha; do Rio Chibarro, com 3.541 ha; e finalmente a do Ribeirão do Pântano, com 1.685 ha (MONTANO, 2002).

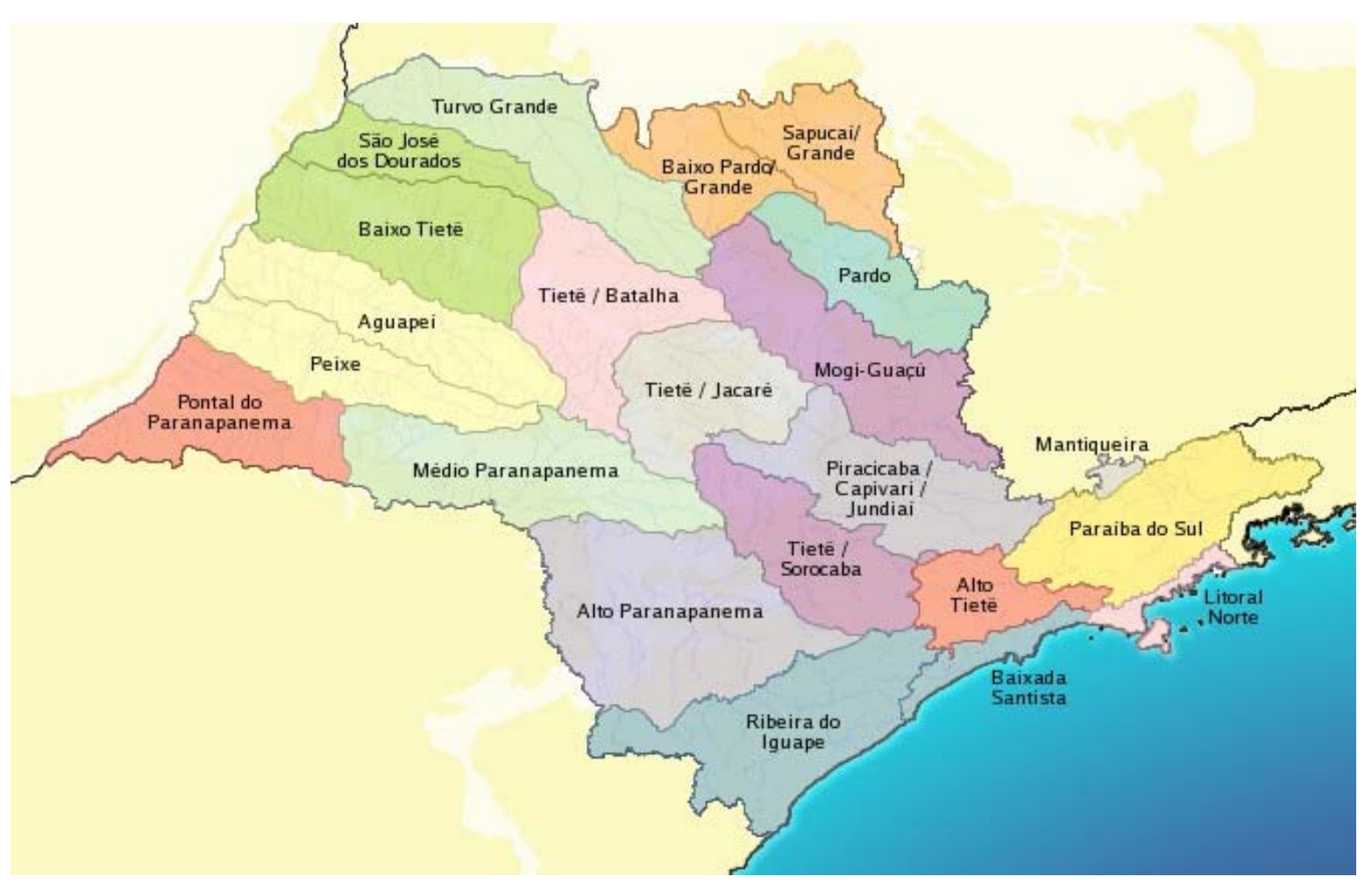

Figura 4: Divisão das 22 Unidades de Gerenciamento de Recursos Hídricos do Estado de São Paulo.

Fonte: DAEE, 2005.

Apesar de ser um município com densidade hídrica elevada — aproximadamente $1 \mathrm{Km}$ linear de corpos d'água superficiais para cada $\mathrm{Km}^{2}$ de área do município possui apenas dois mananciais superficiais para abastecimento público: o Rio do Monjolinho, que percorre aproximadamente $24.060 \mathrm{~m}$ de extensão dentro do município, principal curso d'água na microbacia que recebe o mesmo nome, e o Ribeirão do Feijão, com aproximadamente $13.070 \mathrm{~m}$ de extensão, na divisa Sul do município. Aproximadamente $40 \%$ do abastecimento público municipal são obtidos de captações sub-superficiais.

Em relação aos aspectos de uso e ocupação do solo do perímetro urbano, foi estabelecida a lei municipal de Zoneamento e Perímetro Urbano, n. ${ }^{\circ}$ 6.871/71, modificada pela lei 6.978/72, que define os respectivos perímetros urbanos e industriais. As zonas urbanas definidas por lei são formadas pelas seguintes áreas: 
- $1^{\text {a }}$ Área de Expansão Urbana - é a área central, destinada a uma intensificação do uso do solo, com tendência de ocupação por atividades comerciais, recreativas, institucionais e de prestação de serviços;

- $\quad 2^{\mathbf{a}}$ Área de Expansão Urbana - é toda a área com viabilidade econômica de extensão dos serviços públicos. Destina-se predominantemente à habitação e a seus equipamentos complementares;

- $\quad 3^{\mathrm{a}}$ Área de Expansão Urbana - é a área que não apresenta interesse imediato de ocupação, mas se destina a verificar e controlar as tendências naturais de crescimento.

- Áreas Industriais - as destinadas exclusivamente a instalações de indústrias.

Em relação à proteção ambiental, a lei municipal $n^{0}$ 033/89 dispõe sobre a proteção da flora dentro dos limites da zona urbana e afirma, em seu artigo $1^{\mathrm{o}}$ : "sem consentimento da Prefeitura Municipal, do IBAMA ou de órgão equivalente é proibido cortar, derrubar ou sacrificar árvores de madeira de lei ou vegetação nativa que caracterizem a nossa flora, os recantos naturais, os ambientes antigos e de realizações históricas que celebram o passado e conservam o primitivo, dentro dos limites da Zona Urbana e de Expansão Urbana do Município de São Carlos" (PREFEITURA MUNICIPAL DE SÃO CARLOS, 1989).

Para a atual prefeitura municipal é de fundamental importância a existência de um modelo de desenvolvimento coerente com os princípios da sustentabilidade e baseado na participação democrática, o que está insistentemente demonstrado na lei municipal $\mathrm{n}^{\mathrm{o}}$ 10.257/01 que define o "Estatuto da Cidade" (PREFEITURA MUNICIPAL DE SÃO CARLOS, 2001):

Art. $2^{\circ}-$ A política urbana tem por objetivo ordenar o pleno desenvolvimento das funções sociais da cidade e da propriedade urbana, mediante as seguintes diretrizes gerais:

I - garantia do direito a cidades sustentáveis, entendido como o direito à terra urbana, à moradia, ao saneamento ambiental, à infra-estrutura urbana, ao transporte e aos serviços públicos, ao trabalho e ao lazer, para as presentes e futuras gerações;

II - gestão democrática por meio da participação da população e de associações representativas dos vários segmentos da comunidade na formulação, execução $\mathrm{e}$ acompanhamento de planos, programas e projetos de desenvolvimento urbano; 
IV- planejamento do desenvolvimento das cidades, da distribuição espacial da população e das atividades econômicas do Município e do território sob sua área de influência, de modo a evitar e corrigir distorções do crescimento urbano e seus efeitos negativos sobre o meio ambiente.

Apesar da existência das leis supracitadas de expansão urbana e de proteção ambiental, o que se pôde observar foi um crescimento populacional acelerado em todo o perímetro urbano, que provocou uma intensa ocupação da região sul da cidade, onde se localiza a Microbacia do Córrego da Água Quente. Essa ocupação gerou um aumento na demanda por infra-estrutura e serviços sociais (habitação, educação, saúde, transporte, etc), que evidentemente não foi suprida. $O$ que aconteceu foi a implantação de loteamentos responsáveis pelo surgimento de graves problemas ambientais, e que afetam diretamente a qualidade ambiental dessa microbacia.

O processo de ocupação antrópica que estrutura a cidade e estabelece a lógica de reprodução do espaço urbano, principalmente nos bairros dessa região da cidade é caracterizado por áreas periféricas de baixa renda, cujos lotes, ou foram ocupados de maneira irregular, ou foram "doados" por interesses eleitoreiros, em áreas totalmente inadequadas quanto ao tipo de solo e à falta de infra-estrutura urbana. Esses bairros atualmente absorvem uma parte significativa da arrecadação municipal para o reparo e conservação dessas áreas de difícil manutenção, devido à fragilidade do ecossistema para a habitação.

\subsubsection{A BACIA HIDROGRÁFICA DO RIO DO MONJOLINHO}

Como a Microbacia do Córrego da Água Quente compõe a Bacia do Monjolinho, faremos breves considerações sobre esta última.

$\mathrm{Na}$ porção abrangida pelo município de São Carlos, a Bacia do Rio do Monjolinho está localizada na região centro-oeste, conforme a Figura 5, entre as coordenadas geográficas UTM $181.076 \mathrm{~m}$ e $208.559 \mathrm{~m}$ de longitude Oeste e 7.553.040 m e 7.568.539 m de latitude Sul, perfazendo uma área de 20.610 ha $\left(206,1 \mathrm{Km}^{2}\right)$ e um perímetro de 81.900 m (SÉ, 1992). 
O Rio do Monjolinho nasce no Planalto de São Carlos, a Leste do município, na cota de 900m, percorrendo aproximadamente $24 \mathrm{Km}$ dentro do município e $14 \mathrm{Km}$ estabelecendo o limite entre os municípios de São Carlos e Ibaté, até desaguar no Rio Jacaré-Guaçu, na cota de $540 \mathrm{~m}$, apresentando um desnível de $360 \mathrm{~m}$. A altimetria na área da Bacia Hidrográfica do Monjolinho varia de 560 m a 920 m, de acordo com as informações contidas nas cartas topográficas do IBGE, na escala 1:50.000 (SÉ, 1992).

$\mathrm{Na}$ área da Bacia Hidrográfica do Monjolinho predominam as Formações Geológicas Serra Geral e Formação Botucatu, pertencentes ao Grupo São Bento, e a Formação Adamantina, relativa ao Grupo Bauru. Essa área apresenta uma variedade de formas de relevo, e pertence à Província Geomorfológica das Cuestas Basálticas, onde predominam os relevos de morros. A formação geológica Botucatu mostra caráter contínuo e de espessura variável, expressando-se freqüentemente na forma de escarpas subverticalizadas e alongadas e, menos comumente, por afloramentos isolados, devidos à intensa cobertura proporcionada por sedimentos recentes, sobretudo aqueles de maior contribuição do próprio arenito (AGUIAR, 1988). 


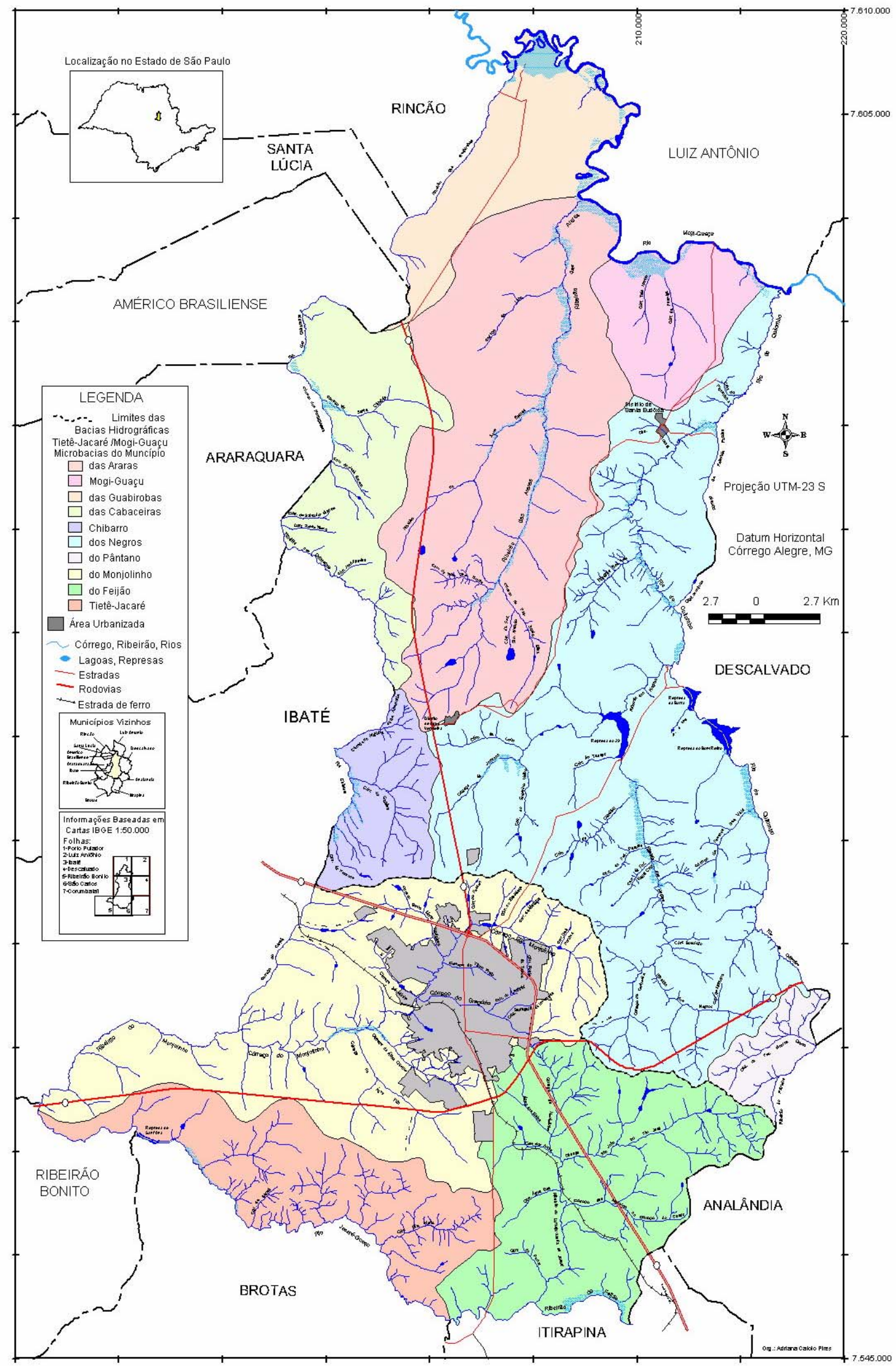

Figura 5: Divisão do Município de São Carlos em bacias.

Fonte: Secretaria Municipal de Desenvolvimento Sustentável, Ciência e Tecnologia de São Carlos (2002). PMSC 
Com relação à fauna de vertebrados (aves, mamíferos, anfíbios, répteis e peixes) Regalado et al (2000) encontraram na Bacia do Rio do Monjolinho 311 espécies, o que corresponde a aproximadamente $20 \%$ do total de espécies descritas no estado de São Paulo, valor considerado relativamente alto frente ao alto grau de fragmentação a que os ecossistemas da Bacia do Monjolinho estão submetidos. Segundo estes autores, a composição faunística da bacia pode ser considerada como resultado da ação conjunta de fatores históricos e ecológicos, em que a fragmentação e a descaracterização do ambiente, ao mesmo tempo em que favorece as espécies mais generalistas e tolerantes, dificulta ou permite a extinção daquelas mais sensíveis e exigentes quanto à integridade ecológica de seus habitats.

Criscuolo et al. (2000) apontam as principais alterações da paisagem na Bacia Hidrográfica do Rio do Monjolinho (BHRM) que também podem ser observadas na Microbacia do Córrego da Água Quente: decréscimo de áreas de vegetação nativa, substituição de parcelas de uso do solo menores, por outras, maiores e mais homogêneas, especialmente área urbana e pastagem. Por sua vez, Côrtes et al. (2000) apontam a degradação dos recursos hídricos na região em função da ocupação desordenada e suas conseqüências (assoreamento, contaminação por efluentes domésticos ou industriais, supressão da mata ciliar e canalização dos cursos d'água, etc.). 
São Carlos tem sua área urbana localizada na Bacia Hidrográfica do Rio do Monjolinho e banhada por vários córregos afluentes deste, que compõem 14 sub-bacias, entre elas a Microbacia do Córrego da Água Quente (Figura 6).

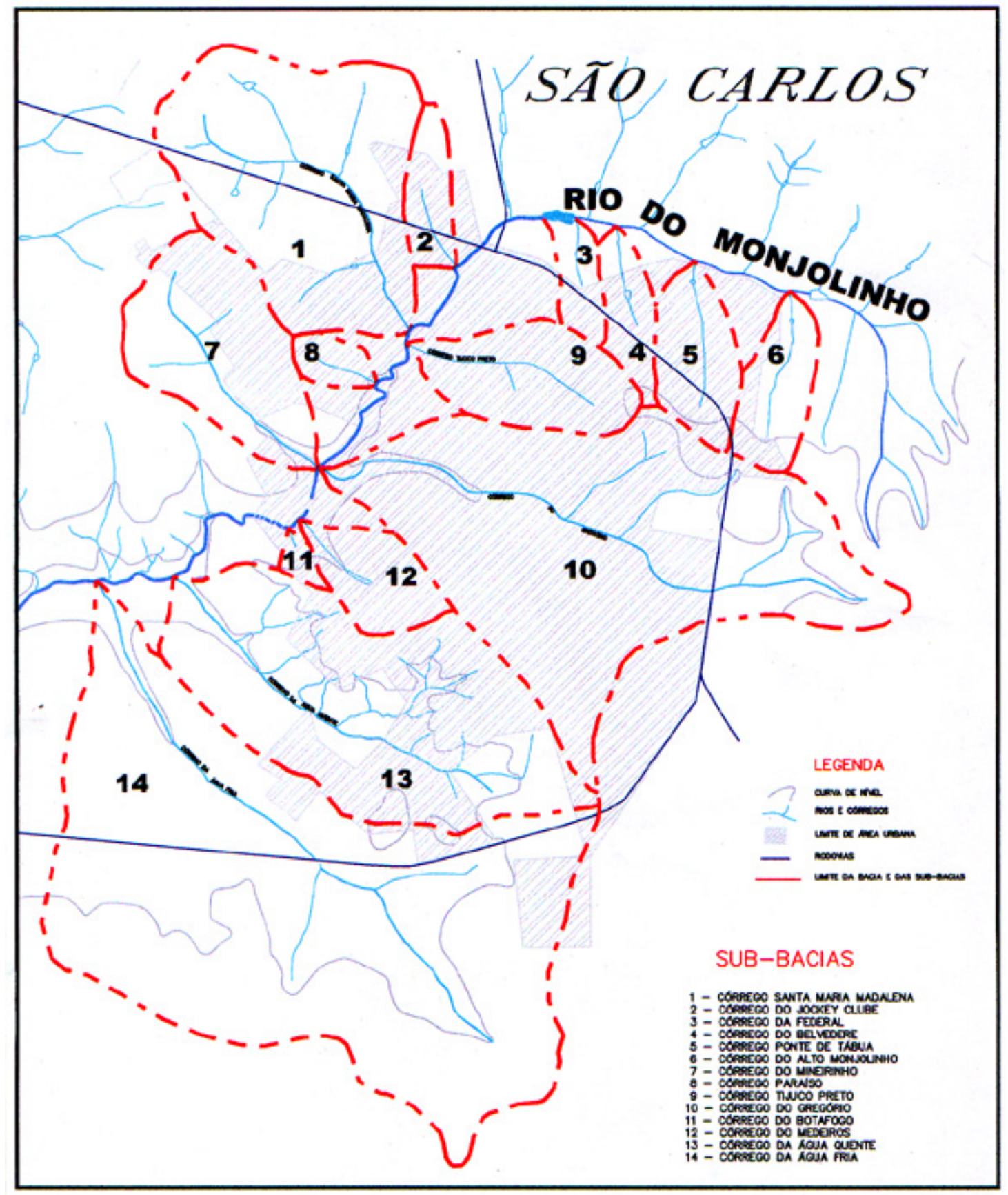

Figura 6: Microbacias urbanas de São Carlos.

Fonte Centro de Divulgação Científica e Cultural da USP (2004). 


\subsubsection{MICROBACIA HIDROGRÁFICA DO CÓRREGO DA ÁGUA QUENTE}

A Microbacia do Córrego da Água Quente (MCAQ) localiza-se na região sul da cidade de São Carlos, Estado de São Paulo e abrange cerca de $12,5 \mathrm{~km}^{2}$. Possui uma população de aproximadamente 35 mil habitantes que moram em 18 bairros (Cidade Aracy, Loteamento Social Antenor Garcia, Jardim Boa Vista, Jardim Medeiros, Jardim Beatriz, Vila Monte Carlo, Vila Conceição, Vila Santa Madre Cabrini, Jardim Gonzaga, Jardim Cruzeiro do Sul, Jardim Santa Teresa, Jardim Pacaembu, Jardim das Rosas, Mirante da Bela Vista, Jardim Belvedere, Jardim das Torres, Jardim Martinelli e Presidente Collor) e cerca de 30 propriedades rurais.

Está inserida na Bacia Hidrográfica do Rio do Monjolinho, onde despeja suas águas. O Rio do Monjolinho, por sua vez, está situado nos municípios de São Carlos e Ibaté (SP), percorrendo 43,25 Km e é afluente do Rio Jacaré-Guaçu (SÉ, 1992). O Jacaré-Guaçu deságua no Rio Tietê, considerado um rio genuinamente paulista, por nascer e percorrer apenas o estado de São Paulo, até desaguar no Rio Paraná, tributário da grande Bacia do Prata, que por sua vez vai encontrar o Oceano Atlântico.

Portanto, ao considerar-se que as bacias hidrográficas, das mais restritas às mais abrangentes, estão inseridas e influenciam o equilíbrio ecológico umas das outras, podese inferir que as alterações ocorridas na microbacia estudada podem, ainda que indiretamente e/ou em um longo prazo, influenciar na qualidade ambiental de grandes bacias formadas com a contribuição de suas águas.

A qualidade da MCAQ influencia a qualidade da Bacia do Monjolinho, que por sua vez pode prejudicar a qualidade do Rio Jacaré, e assim por diante. Ao se trabalhar com Educação Ambiental utilizando-se a microbacia como unidade de estudo, essa visão micro e macro-ecossistêmica possibilita a compreensão das relações entre os aspectos locais e globais, nos quais estão incluídas a participação e a responsabilidade de cada ser humano.

A Figura 7 compreende a Bacia do Rio do Monjolinho e destaca os seus tributários, entre eles o Córrego da Água Quente. 

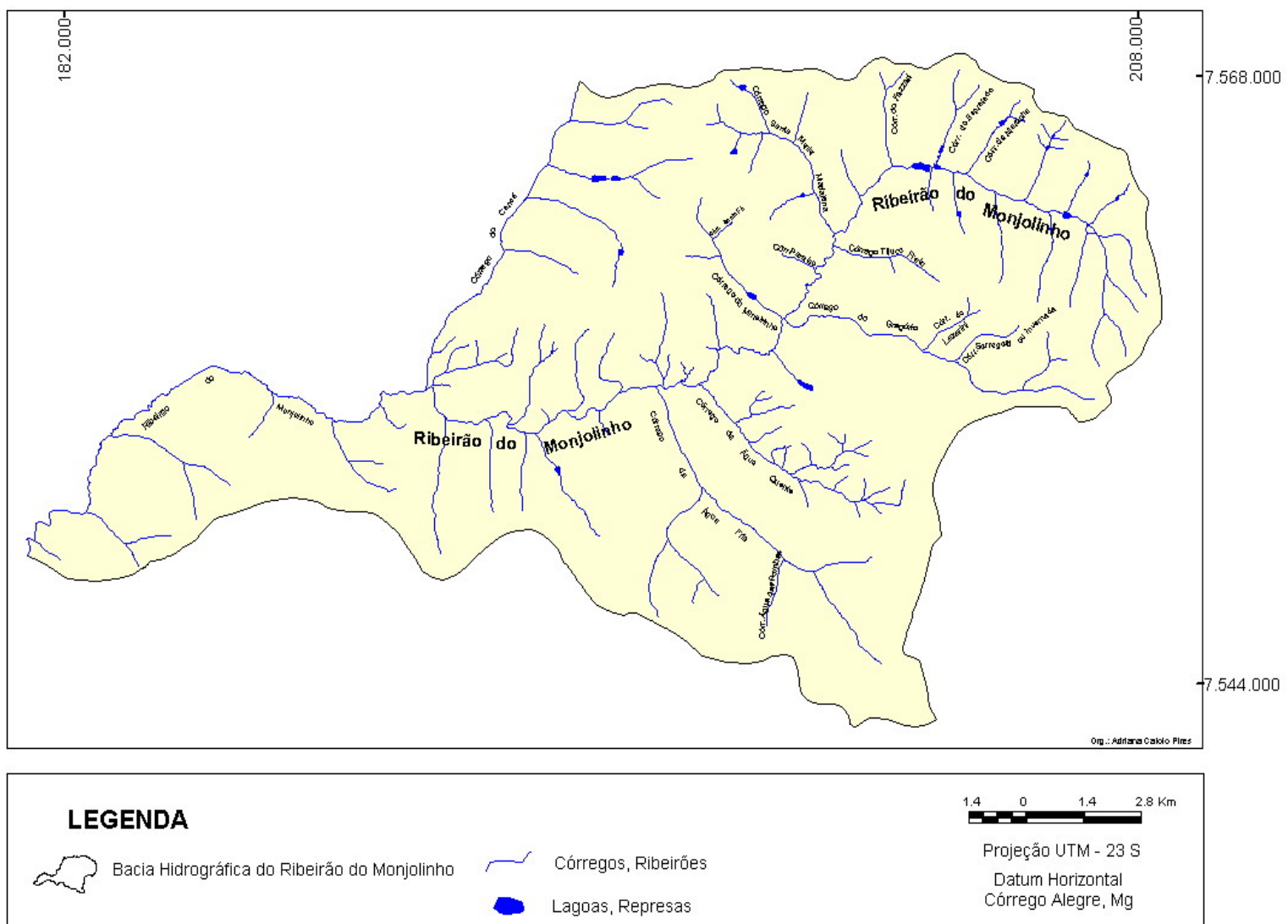

FIGURA 7: Tributários da Bacia Hidrográfica do Rio do Monjolinho (trecho referente ao município de São Carlos).

Fonte: Secretaria Municipal de Desenvolvimento Sustentável, Ciência e Tecnologia, 2002. PMSC.

As altitudes da MCAQ variam entre $600 \mathrm{~m}$ e $900 \mathrm{~m}$, e a ocupação urbana, a planimetria e a altimetria estão demonstradas na Figura 8. Vale lembrar que a alteração da malha urbana é extremamente dinâmica nessa região, e que mais alguns loteamentos, como o Jardim Martinelli, somam-se a estes representados na figura 8. 


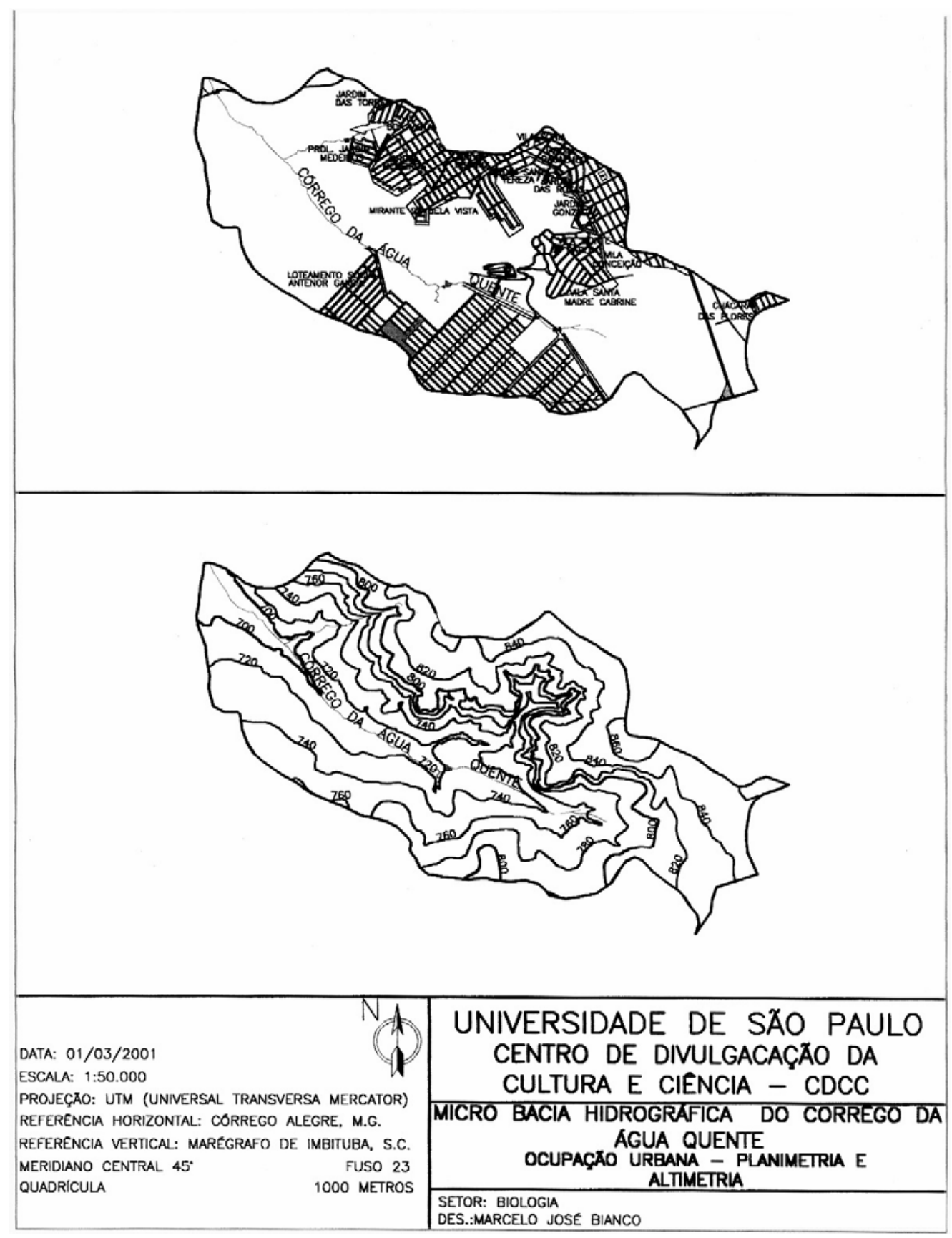

Figura 8: Microbacia Hidrográfica do Córrego da Água Quente. Fonte: CDCC, 2001.

Terrenos com grande declividade são considerados inadequados para a ocupação urbana, devido aos problemas de instabilidade e outros, pois a declividade contribui para o escoamento das águas. Quanto maior for o trecho em declive, maior será o escoamento da água pela superfície, carreando o solo e outros materiais para os recursos hídricos superficiais, influindo, portanto, na qualidade da água dos mesmos. 
Na porção sul de São Carlos, onde se localiza essa microbacia, a declividade predominante é de 2 a 5\% e a densidade de drenagem é baixa (GONÇALVES, 1986). A microbacia é ocupada pela Formação Botucatu, expressa pelo arenito com cimento não silicoso, e material de cobertura inconsolidado geralmente heterogêneo, e os solos formados no arenito Botucatu são tipicamente de cor avermelhada clara (sendo em alguns casos amarelada), arenosos e pobres em matéria orgânica. Praticamente não há diferenciação pedológica de horizontes no perfil desse tipo de solo (LORANDI, 1985).

A pedologia da MCAQ pode ser observada na Figura 9, que compreende a pedologia da Bacia do Rio do Monjolinho.

Apesar dessa área ser classificada pelo zoneamento urbano como sem interesse imediato de ocupação ( $3^{\mathrm{a}}$ área de expansão urbana), é atualmente uma das regiões que apresenta maior índice de crescimento populacional da cidade. Esse crescimento tem ocorrido de forma desordenada, sem a continuidade do novo traçado com a rede viária existente, permitindo a criação de vazios urbanos entre áreas ocupadas e com subutilização da infra-estrutura existente, gerando periferias carentes, que muitas vezes habitam em áreas de alto risco de desmoronamento devido à declividade e tipo de solo, como é o caso de cerca de 15 famílias no bairro Monte Carlo (TÓRO-TONISSI e TONISSI, 2002). 


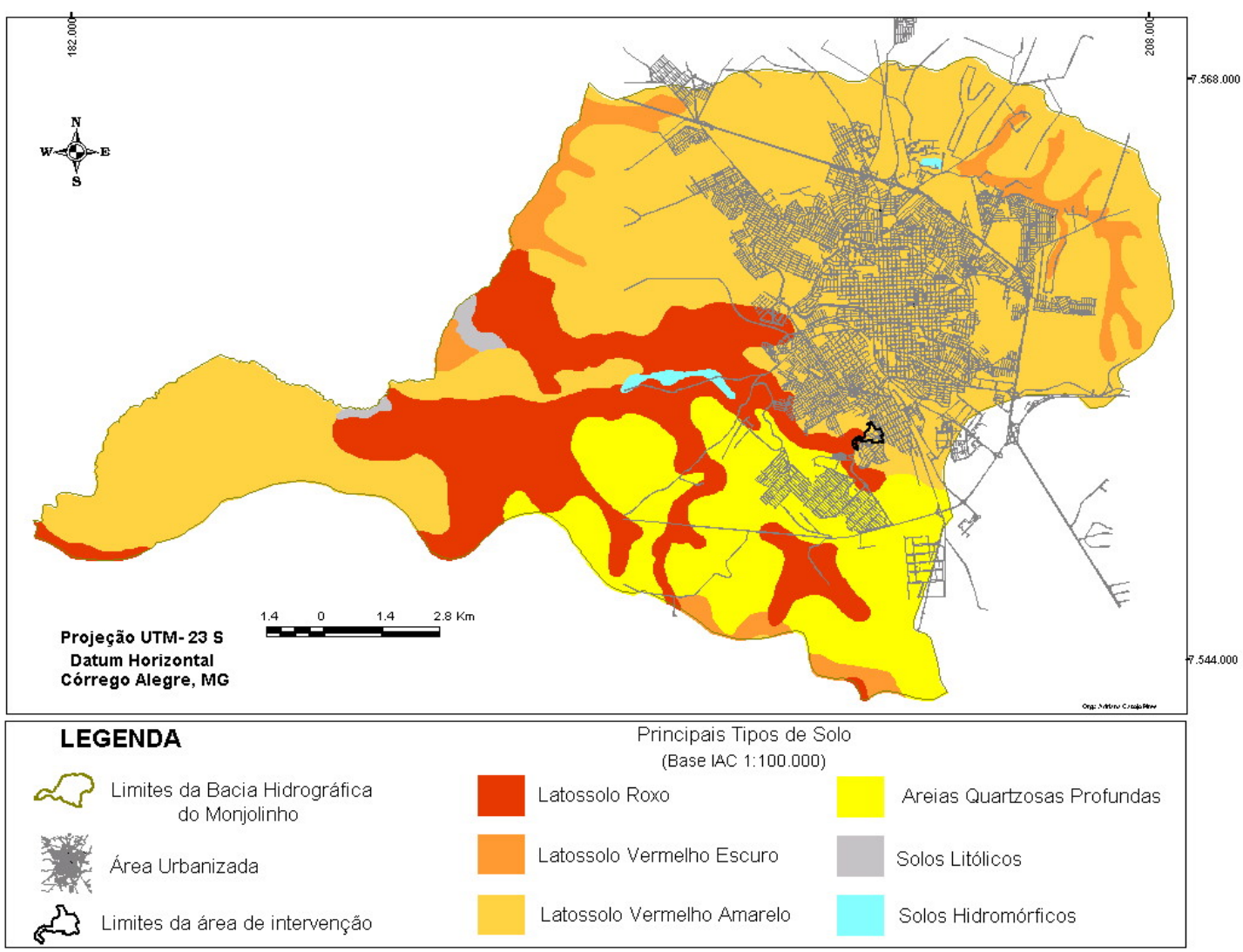

Figura 9: Pedologia da Bacia do Rio do Monjolinho, que inclui a pedologia da MCAQ. Fonte: Espindola et al. (2000) (mapa anexo). PMSC. 


\section{JUSTIFICATIVA}

A Microbacia do Córrego da Água Quente (São Carlos-SP) possui uma área verde, considerada área de recarga do Aqüífero Guarani e composta por variadas paisagens, desde planícies até um trecho de "cuestas", com várias nascentes e fragmentos significativos de vegetação nativa, como cerrado (do qual restam apenas cerca de $15 \%$ no Brasil) e matas ciliares em alguns trechos dos corpos d'água, além de algumas espécies animais em risco de extinção. Por outro lado, a área recebe efluentes líquidos e resíduos sólidos que evidentemente prejudicam a qualidade da água e do solo, e devido à fragilidade do solo (predominantemente arenoso), aos desmatamentos e queimadas e ao pisoteamento por animais, vêm ocorrendo graves processos erosivos em diversos pontos da microbacia, principalmente nas regiões próximas às nascentes. Além disso, essa microbacia é predominantemente ocupada por uma população de baixa renda, aglomerada em bolsões de acentuada pobreza como nos bairros Jardim Gonzaga, Monte Carlo e Antenor Garcia, e que entre várias outras carências, praticamente não possuem áreas de lazer. Todas essas características evidenciam a urgência de se investir na recuperação e conservação da qualidade ambiental dessa área verde, considerando-se a necessidade de ações urgentes que reduzam a acelerada degradação do local, e supram a necessidade de áreas de lazer e contato com a natureza para a comunidade da microbacia.

Para que as ações de manejo sejam permanentes, sustentáveis e compatíveis com as reais necessidades da comunidade local, entendemos que é essencial a participação desta no processo de recuperação e conservação da área verde, e que o estudo da percepção da população (incluindo as relações de topofilia e os saberes locais sobre esse ecossistema) é o primeiro passo para a elaboração de projetos que motivem essa participação. Esses projetos podem contribuir para a comunidade conhecer as características e funções ambientais do local, reconhecer o seu direito à participação nas decisões que dizem respeito à microbacia onde vive, e estar ambientalmente consciente sobre seu papel como sujeito histórico na manutenção dessa área.

Nesse contexto, entende-se que a geração e disponibilização de informações sobre a área verde (com ênfase na qualidade da água que por vezes é inclusive utilizada para consumo humano), poderão subsidiar projetos de Educação Ambiental a serem desenvolvidos pelas escolas inseridas nesta bacia e junto à população dos 18 bairros que a compõem. 


\section{OBJETIVOS}

\subsection{OBJETIVO GERAL}

A partir da caracterização ambiental da área verde da Microbacia do Córrego da Água Quente e do estudo da percepção da comunidade local em relação a essa área verde, gerar e disponibilizar informações para subsidiar projetos de EA que visem a recuperação e conservação desse ecossistema.

\subsection{OBJETIVOS ESPECÍFICOS}

- Realizar a caracterização socioeconômica da população da microbacia;

- Levantar informações sobre a qualidade dos corpos d'água da microbacia através da caracterização limnológica;

- Realizar um levantamento preliminar da vegetação e da fauna da área verde da MCAQ;

- Avaliar a percepção ambiental da população da microbacia (estudantes do ensino médio e pessoas residentes no entorno da área verde), em relação à qualidade ambiental dessa área;

- Estudar as relações topofílicas da comunidade local com a área verde da microbacia;

- Realizar uma análise comparativa entre os conhecimentos da comunidade local acerca da área verde e os conhecimentos gerados nos levantamentos;

- Disponibilizar as informações sobre a situação ambiental da área verde da MCAQ em encontros educativos nas escolas participantes;

- Implementar atividades educativas junto às turmas de estudantes, visando a reflexão sobre a situação ambiental da microbacia e a motivação para a elaboração de sugestões para a confecção de uma proposta para o manejo sustentável da área verde;

- Comparar as sugestões de manejo para a área elaboradas pelas(os) estudantes antes e após os encontros educativos. 


\section{PROCEDIMENTOS METODOLÓGICOS}

\subsection{TÉCNICAS PARA A INVESTIGAÇÃO DA QUALIDADE DA ÁGUA}

\subsubsection{PONTOS DE COLETA E ÉPOCA DAS COLETAS}

As coletas de água para as análises limnológicas foram realizadas mensalmente, no período de dezembro de 2001 a dezembro de 2002. Esse intervalo de coletas foi escolhido visando comparar a qualidade da água ao longo do ano, durante as estações chuvosa e seca.

Considerando-se a diversidade de características paisagísticas e de ocupação da Microbacia do Córrego da Água Quente, para a realização deste trabalho foram escolhidos nove pontos de relevante interesse, sendo quatro nascentes e cinco pontos ao longo do córrego.

\subsubsection{DESCRIÇÃO DOS PONTOS DE COLETA}

Inicialmente, as amostras eram coletadas em seis pontos. Ao longo do desenvolvimento da pesquisa, através de conversas com moradoras(es) da região, foram identificados novos pontos de interesse para essa pesquisa - como uma área de nascente localizada em propriedade particular, que é o ponto N-Horta - e, a partir de junho de 2002, passou-se a coletar amostras em nove pontos.

Foram realizadas 13 coletas, com exceção das coletas para análise de coliformes, que ocorreram nos meses de dezembro de 2001, janeiro e fevereiro de 2002, durante o período chuvoso, e em junho, julho e agosto de 2002, no período seco, somente em três nascentes, por serem os locais que, segundo informações de alguns moradores da área, a população tem maior contato.

A Figura 10 é uma imagem de satélite da Microbacia do Córrego da Água Quente obtida em junho de 2004 na qual podem ser observados os pontos de coleta e os bairros onde residem os membros da comunidade que participaram do estudo da percepção. 


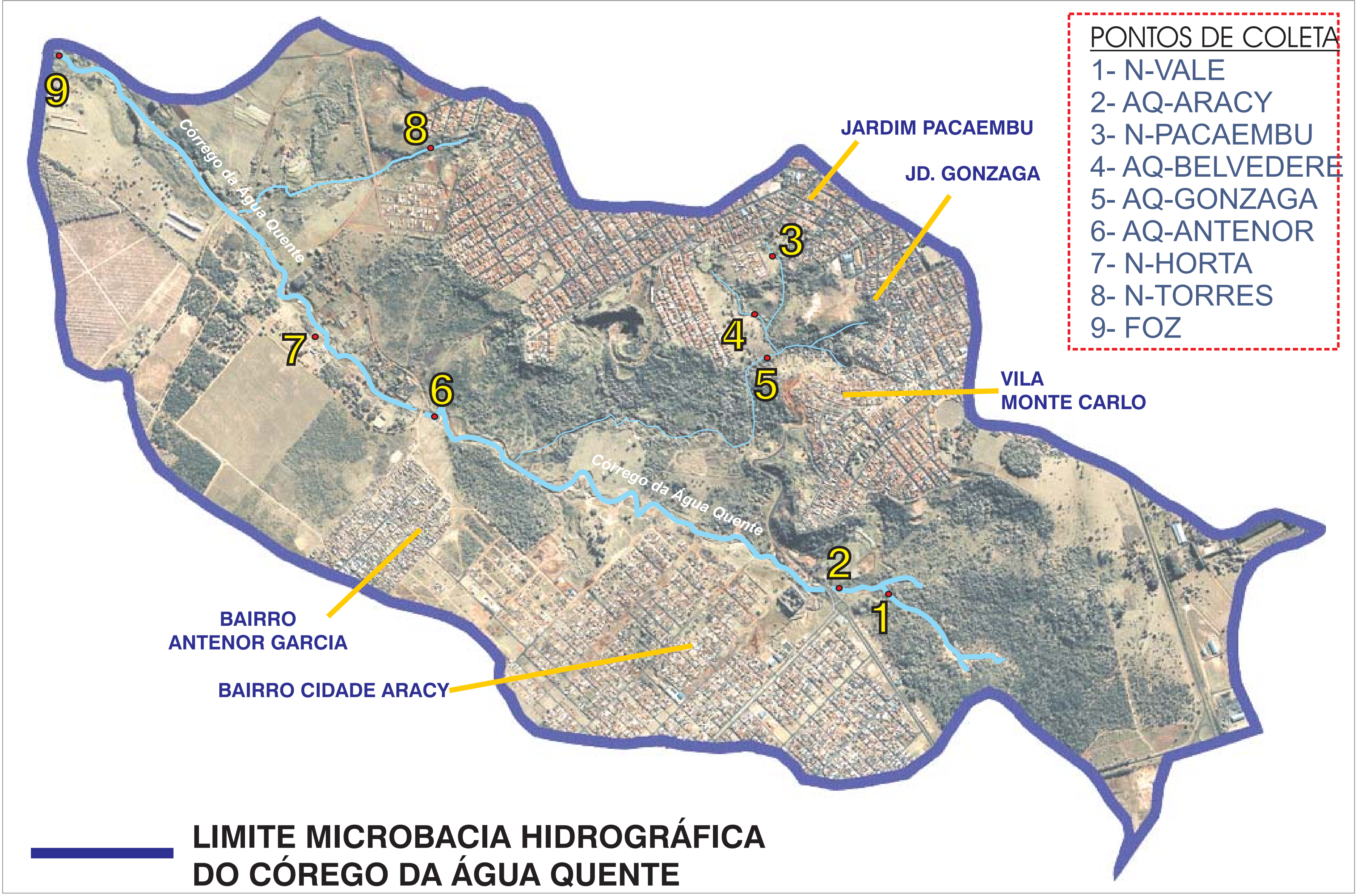

Figura 10: Vista da bacia e localização dos pontos de coleta e dos bairros participantes

Fonte da imagem: Secr. Municipal de Desenv. Urbano e Habitação - jun 2004. Prefeitura Municipal de São Carlos. 
Os nove pontos de coleta incluem quatro nascentes (N-Vale, N-Pacaembu, NTorres e N-Horta) sendo que as três primeiras abastecem diretamente o Córrego da Água Quente, e segundo alguns relatos (comunicação oral de moradores) têm suas águas consumidas por pessoas que freqüentam a área. A N-Horta foi transformada em um poço que atende a uma horta. E mais cinco pontos ao longo do córrego (AQ-Aracy, AQ-Belvedere, AQ-Gonzaga, AQ-Antenor e Foz). As coletas ocorreram sempre pela manhã, das 8:00 às 9:00 horas, na seguinte seqüência: N-Pacaembu, AQ-Belvedere, AQ-Gonzaga, N-Vale, AQ-Aracy, AQ- Antenor, N-Torres, Foz, N-Horta.

A N-Vale (Figura 11) localiza-se mais à montante do córrego, e dentre todos os pontos, é o que recebe menor interferência antrópica. Mesmo assim, no início da nascente (aproximadamente $400 \mathrm{~m}$ acima do ponto N-Vale), observa-se uma erosão de dimensões gigantescas, sendo que neste trecho o córrego é intensamente assoreado pela supressão da mata ciliar e pelo pisoteamento de animais, principalmente cavalos e bois. Já o trecho do ponto N-Vale, é parcialmente protegido por mata ciliar, medindo cerca de 2,0 $\mathrm{m}$ de largura.

Cerca de $100 \mathrm{~m}$ abaixo da N-Vale, quando as águas dessa nascente já receberam grande aporte de efluentes domiciliares, encontra-se o ponto AQ-Aracy (Figura 12), com mata ciliar bastante escassa e totalmente assoreado, medindo cerca de $7 \mathrm{~m}$ de largura.

A N-Pacaembu (Figura 13), por sua vez, constitui uma nascente situada a cerca de $60 \mathrm{~m}$ abaixo da Avenida Pacaembu. No passado, essa nascente aflorava na atual casa de um dos entrevistados, a cerca de $100 \mathrm{~m}$ de distância de sua localização atual. O morador contou que no período chuvoso sua "cisterna" transbordava, motivo pelo qual teve que tampá-la. Atualmente existe uma tubulação para drenar a água e praticamente não há vegetação ciliar, sendo utilizada para a dessedentação de animais.

Os pontos AQ-Belvedere (Figura 14) e AQ-Gonzaga (Figura 15) localizam-se no fundo de vale da área verde, próximos aos bairros de mesmo nome. O AQBelvedere, apesar de ser o ponto que apresenta mata ciliar menos alterada e menor assoreamento (medindo cerca de $1,5 \mathrm{~m}$ de largura), é formado pelas águas na $\mathrm{N}$ Pacaembu, juntamente com grande aporte de efluentes domésticos despejados in natura, e vai abastecer o AQ-Gonzaga, que também recebe as águas de nascentes e efluentes vindos dos bairros Jardim Gonzaga e Monte Carlo. A vegetação ciliar do trecho do AQGonzaga também encontra-se impactada, principalmente pela erosão das margens, e nesse trecho o leito chega a $4 \mathrm{~m}$ de largura. 
No fundo de vale próximo ao bairro Jardim das Torres, situa-se o ponto NTorres (Figura 16), que dista cerca de $50 \mathrm{~m}$ do início da nascente, possui vegetação ciliar parcialmente alterada e aspecto cristalino, com exceção dos meses de janeiro a março de 2002, em que rompera uma tubulação de esgoto que se juntou às suas águas nesse período.

O AQ-Antenor (Figura 17), próximo ao bairro Antenor Garcia, localiza-se em um trecho do córrego que já recebeu, além das águas da porção direita da microbacia, também toda água e efluentes da porção esquerda, onde situam-se os bairros Cidade Aracy I e II e Antenor Garcia. Praticamente não possui vegetação ciliar, e a erosão de suas margens, juntamente com enorme quantidade de entulhos de construção e outros tipos de resíduos ali depositados, provocaram um intenso assoreamento do córrego, que possui cerca de $8 \mathrm{~m}$ de largura neste trecho.

A N-Horta (Figura 18) localiza-se em uma horta de propriedade particular e, como já foi dito, é uma nascente transformada em poço. Não possui mata ciliar, apenas capim, e possivelmente recebe fezes de animais domésticos que habitam o local.

O ponto Foz (Figura 19) está situado em uma propriedade particular a cerca de $100 \mathrm{~m}$ do encontro do Córrego da Água Quente com o Rio do Monjolinho, em um trecho totalmente sem mata ciliar e assoreado, medindo cerca de $6 \mathrm{~m}$ de largura. O ponto da Foz demonstra a concentração de substâncias poluentes que o Córrego Água Quente deposita no Rio do Monjolinho, no qual deságua. 


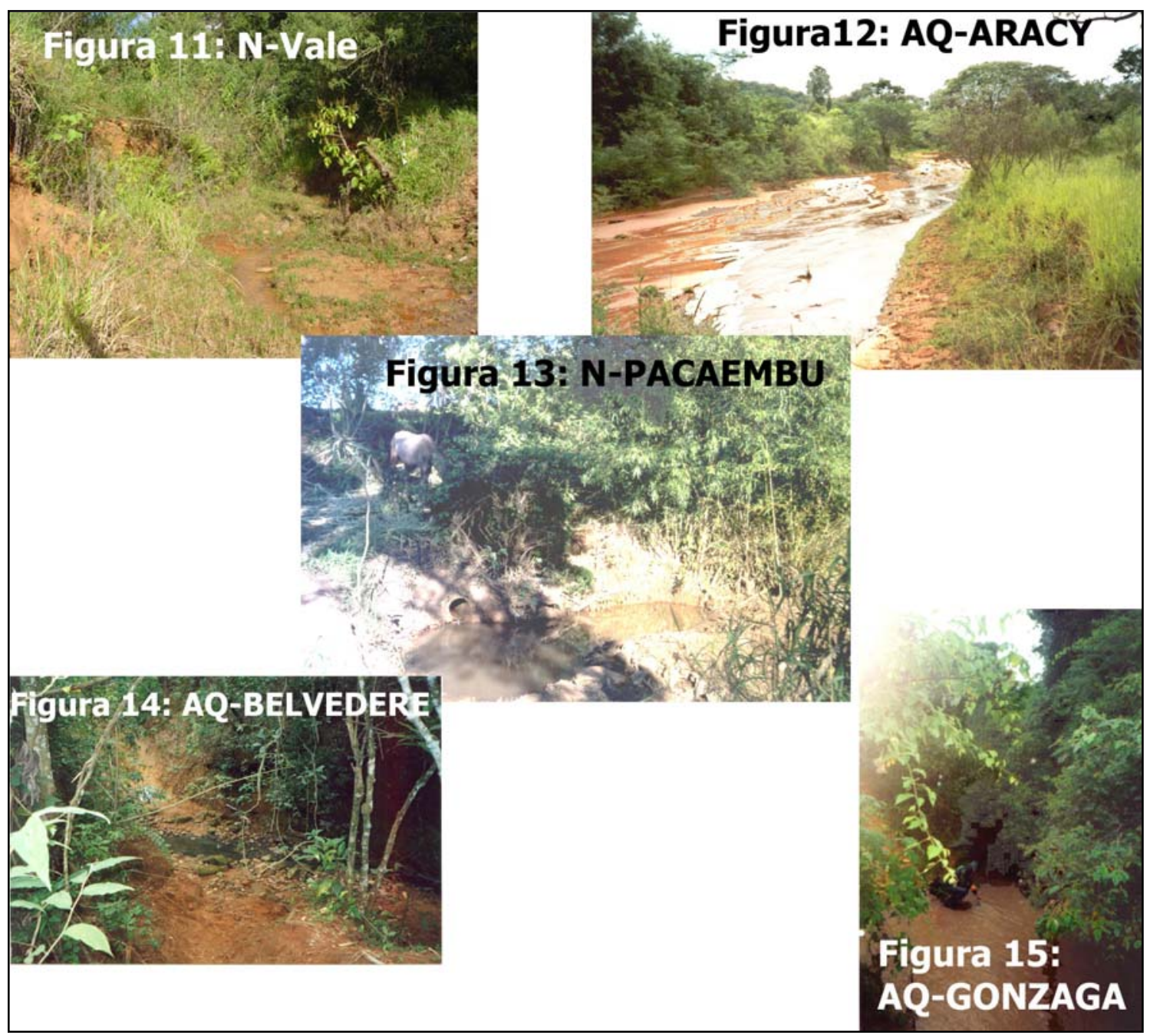

Figuras 11 a 15: Pontos de coleta - N-Vale, AQ-Aracy, N-Pacaembu, AQ-Belvedere e AQ-Gonzaga - da Microbacia Hidrográfica do Córrego da Água Quente, São Carlos,SP. 


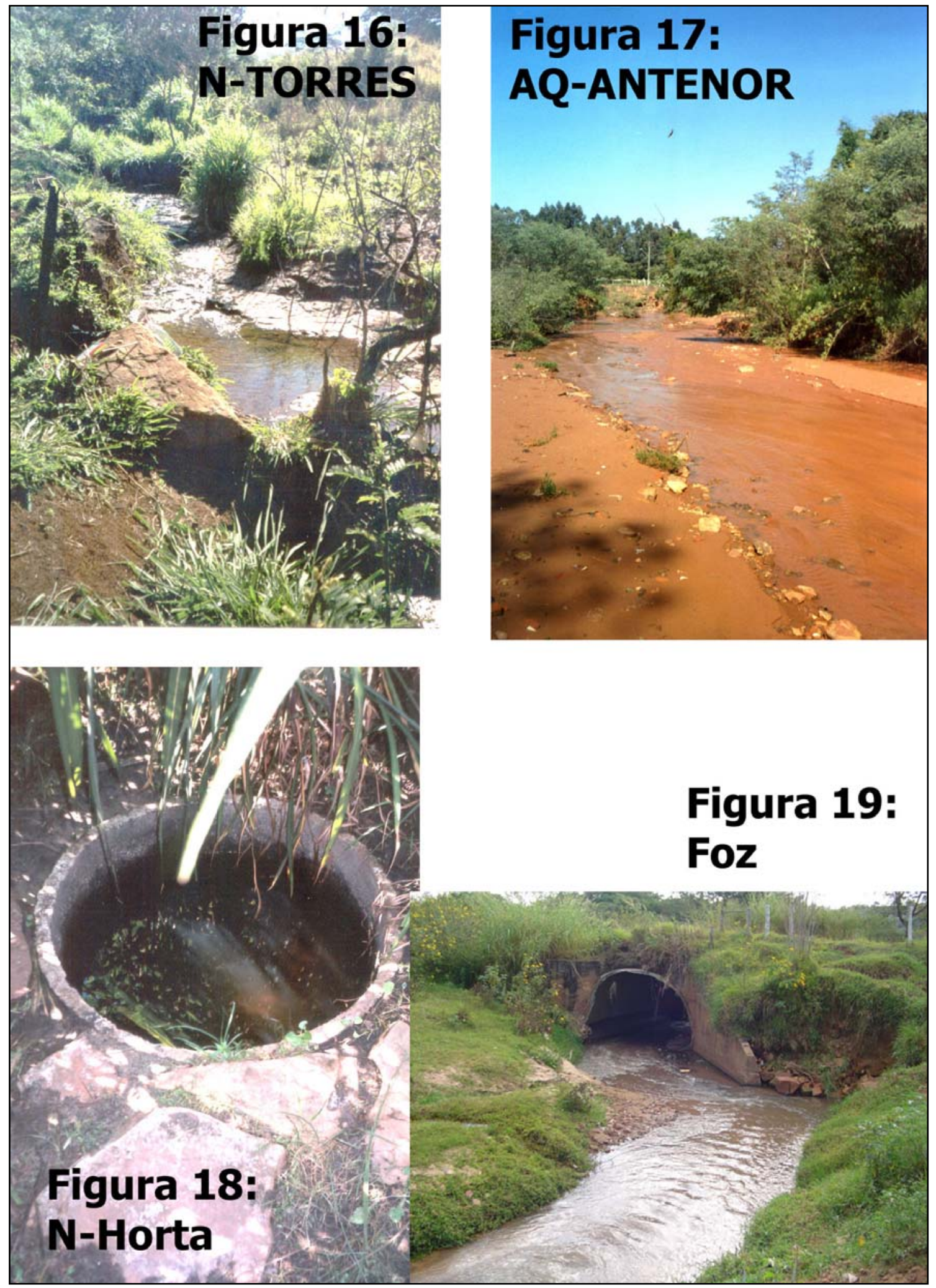

Figuras 16 a 19: Pontos de coleta - N-Torres, AQ-Antenor, N-Horta e Foz - da Microbacia Hidrográfica do Córrego da Água Quente, São Carlos,SP. 


\subsubsection{VARIÁVEIS CLIMATOLÓGICAS}

Os dados de temperatura do ar $\left({ }^{\circ} \mathrm{C}\right)$ e de precipitação $(\mathrm{mm})$ foram obtidos na Estação Climatológica do Centro de Recursos Hídricos e Ecologia Aplicada da Escola de Engenharia de São Carlos, da Universidade de São Paulo, para dezembro de 2001 e para o ano de 2002.

\subsubsection{VARIÁVEIS FÍSICAS, QUÍMICAS E BIOLÓGICAS DA ÁGUA}

Para caracterizar limnologicamente o sistema foram efetuadas as medidas de variáveis limnológicas como temperatura, $\mathrm{pH}$, condutividade e oxigênio dissolvido, utilizando-se o "Water Quality Checker", marca HORIBA, modelo U-10. As amostras para determinação de nutrientes nas formas nitrogenadas e fosfatadas foram coletadas e acondicionadas em frascos de polietileno, sendo que aquelas destinadas à análise de nutrientes dissolvidos foram obtidas por meio de filtração prévia em filtros $\mathrm{GF} / \mathrm{C}$ WHATMAN, com $47 \mathrm{~mm}$ de diâmetro, e congeladas para posterior análise em laboratório. A metodologia específica para cada análise encontra-se no quadro 1.

\begin{tabular}{|l|c|l|}
\hline Variáveis & Unidades & Métodos \\
\hline Temperatura da água & ${ }^{\mathbf{0}} \mathrm{C}$ & $\begin{array}{l}\text { Eletrométrico (Leitura direta na } \\
\text { água na sombra) }\end{array}$ \\
\hline Oxigênio dissolvido & $\mathrm{mg} / \mathrm{L}$ & Eletrométrico \\
\hline $\mathrm{pH}$ & --- & Eletrométrico \\
\hline Condutividade & $\mu \mathrm{s} / \mathrm{cm}$ & Eletrométrico \\
\hline Turbidez & $\mathrm{NTU}$ & $\begin{array}{l}\text { Turbidímetro } \\
\text { (Modelo } \\
\text { CHEMICAL CO.) }\end{array}$ \\
\hline Nitrito & & MACKERETH et al. (1978) \\
\hline Nitrato & $\mu \mathrm{H} / \mathrm{L}$ & MACKERETH et al. (1978) \\
\hline Nitrogênio orgânico total & $\mu \mathrm{g} / \mathrm{L}$ & GOLTERMAN et al. (1978) \\
\hline Fosfato total dissolvido & $\mu \mathrm{L} / \mathrm{L}$ & GOLTERMAN et al (1978) \\
\hline Fosfato inorgânico & $\mu \mathrm{g} / \mathrm{L}$ & GOLTERMAN et al (1978) \\
\hline Fósforo total & $\mu \mathrm{g} / \mathrm{L}$ & APHA/WWW (1995) \\
\hline Amônio & $\mu \mathrm{g} / \mathrm{L}$ & KOROLEFF (1976) \\
\hline Coliformes totais e fecais & $\mathrm{NMP}$ & APHA/WWW (1998) \\
\hline
\end{tabular}

Quadro 1: Variáveis limnológicas e forma de análise. 


\subsubsection{ANÁLISE ESTATÍSTICA DAS CARACTERÍSTICAS LIMNOLÓGICAS}

O método utilizado para a análise estatística dos resultados da qualidade de água foi a análise de componentes principais (ACP), realizada com o auxílio do programa XL STAT 5.2.

Foi realizada uma ACP para se elucidar a tendência que certas variáveis possuíam em influenciar a qualidade da água. A partir dos dados coletados, foi estabelecida uma matriz de correlação entre as variáveis. No espaço, cada correlação determina uma dimensão, da qual se tem um eixo de regressão da distribuição de variância, os quais são ortogonais entre si. Dos resultados desta matriz, são calculados os Eigen-valores e os Eigen-vetores associados a estes. Os Eigen-valores estandartizam os dados e fornecem um ranking associado às variáveis. A partir deste ranking, são estabelecidos os componentes principais, ou seja, agrupamento de fatores que corroboram significativamente para a variância observada. E os Eigen-vetores determinam a orientação espacial dos eixos de correlação.

Para facilitar a análise das correlações, de forma a se ter uma tendência da variância entre os dados (comportamento das variáveis) procura-se extrair o máximo de informações em um número mínimo de dimensões que expliquem de forma segura e satisfatória os dados coletados. Ou seja, substituir um conjunto inicial de variáveis correlacionadas, por um número menor de fatores, porém com grande significância, que explicam a maior parte de variabilidade do conjunto original de dados.

Para tanto, observam-se os Eigen-valores obtidos para cada variável, sendo que os maiores Eigen-valores compõem os principais componentes do respectivo Eigenvetor. Em geral, utiliza-se um número de vetores suficientes para explicar mais de 50\% das variâncias, o que representa, geralmente, duas dimensões de eixos. Três ou mais eixos de componentes principais podem ser representados graficamente, mas a interpretação fica extremamente complexa, devido ao número elevado de dimensões.

Segundo Legendre \& Legendre (1983) a ACP é uma das técnicas de ordenação mais eficazes para exprimir a complexidade existente entre as variáveis em estudo, e evidencia as principais tendências de variabilidade entre os parâmetros amostrados. Essa técnica reduz o número de variáveis em subgrupos menores de variáveis relacionadas entre si (fatores), o que permite explicar a maior variabilidade possível do conjunto de dados. 


\subsection{TÉCNICAS PARA O LEVANTAMENTO DE FAUNA E VEGETAÇÃO}

A caracterização de espécies que compõem um ecossistema tem sido largamente utilizada como um importante indicador da integridade ecológica e da qualidade ambiental de uma área. Os estudos de biodiversidade de espécies de uma bacia hidrográfica facilitam a compreensão do estado de degradação, além de alertar para a importância da recuperação e conservação da paisagem e a sobrevivência das espécies que ainda restam no ecossistema. Buscando-se obter subsídios para o desenvolvimento de projetos de Educação Ambiental na MCAQ, realizamos um breve levantamento da biodiversidade da microbacia, de caráter qualitativo. Nesse levantamento destacamos espécies da flora e da avifauna, por serem dois grupos de organismos que acreditamos contribuir de modo significativo para a sensibilização da população, e que são adequadas à utilização da técnica da espécie-bandeira (DIETZ e NAGAGATA, 1997). Essa técnica consiste em destacar uma ou mais espécies existentes no local, que por alguma característica especial possa motivar a sensibilização (espécie em extinção, espécie com valor medicinal ou alimentício notável, espécie de rara beleza, entre outras).

\subsubsection{FAUNA}

A caracterização qualitativa da avifauna foi realizada a partir de dois levantamentos em campo e das observações durante todas as vezes que estivemos na área verde, com o auxílio de um especialista. A presença das espécies foi registrada por observações visuais e/ou auditivas, análise de vestígios (ninhos, pegadas e fezes). A partir desse levantamento elaboramos uma listagem de espécies, com sugestões de algumas aves para a aplicação da técnica de espécie-bandeira.

\subsubsection{VEGETAÇÃO}

Durante o contato com a população da microbacia foi identificado um morador que detém grande conhecimento em relação às espécies vegetais nativas. Nos dias 23/08/2004, 05/12/2004 e 13/04/2005 realizamos com ele excursões ao longo da área 
verde, em trechos próximos às margens do Córrego da Água Quente, nas quais esse morador do bairro Jardim Gonzaga identificou várias espécies vegetais arbóreas, arbustivas e herbáceas, e descreveu seus usos mais comuns pelo ser humano. As espécies encontradas nesses três levantamentos, assim como as espécies coletadas com podão ou manualmente em várias excursões assistemáticas à área verde, foram filmadas e fotografadas para facilitar a classificação. Em seguida, foi realizada uma comparação entre as informações obtidas em campo e a literatura especializada (LORENZI, 1998a; LORENZI, 1998b; LORENZI, 2002; DURIGAN et al., 2004).

\subsection{TÉCNICAS PARA COLETA DE DADOS SOCIOECONÔMICOS E DE PERCEPÇÃO AMBIENTAL E TOPOFILIA}

Os dados para o levantamento da percepção e topofilia da comunidade local em relação à área verde da Microbacia do Córrego da Água Quente foram coletados através da seguintes técnicas:

- 40 entrevistas semi-estruturadas com pessoas adultas e residentes em locais próximos à área verde da microbacia;

- mapas mentais e questionários aplicados a estudantes da terceira série do Ensino Médio de três escolas estaduais situadas na microbacia;

\subsubsection{ENTREVISTA QUALITATIVA}

A entrevista qualitativa é uma técnica utilizada para mapear e compreender o mundo da vida das(os) respondentes, fornecendo os dados necessários para o estudo das relações entre os atores sociais e sua realidade. A finalidade da pesquisa qualitativa é explorar o espectro de opiniões sobre o assunto em questão (BAUER e GASKELL, 2003).

Bauer e Gaskell (op. cit.), afirmam que toda pesquisa com entrevistas é um processo social, uma interação em que ocorre uma troca de idéias e de significados entre entrevistador(a) e respondente, em que várias realidades e percepções são exploradas e desenvolvidas. Além da fala, que é o principal meio de troca, existem outras formas de comunicação que influenciam na entrevista (olhar, tom de voz, forma de abordagem, 
uso de gravador, linguagem), e a(o) entrevistada(o), tanto quanto a(o) entrevistador(a) estão envolvidas(os) na produção de conhecimento, embora na maioria das vezes somente $\mathrm{a}(\mathrm{o})$ pesquisador(a) esteja consciente disso. Por ser este um estudo em Educação Ambiental, entende-se que a própria entrevista já é uma intervenção educativa significativa, pois é o início de um processo de sensibilização da(o) entrevistada(o), que pode ou não ter refletido anteriormente sobre o assunto abordado.

Selltiz et al. (1967) considera a entrevista uma técnica bastante adequada para se obter informações sobre o que as pessoas sabem, sentem, crêem, esperam, pretendem fazer, fazem ou fizeram, bem como acerca de suas explicações e razões a respeito das coisas precedentes.

De acordo com Gil (1999), Goode e Hatt (1997) e Lüdke e André (1986) é apontada uma série de vantagens e desvantagens da entrevista, resumidas a seguir:

\section{Vantagens:}

- podem ser feitas as mesmas perguntas de forma homogênea a todas as pessoas entrevistadas;

- permite a obtenção de dados referentes aos mais diversos aspectos da vida social, e o aprofundamento nas respostas;

- os dados são suscetíveis de classificação e quantificação, e não é necessário que as(os) entrevistadas(os) saibam ler e escrever;

- possibilita a obtenção de um maior número de respostas e de respostas mais completas, posto que a(o) entrevistador(a) tem a chance de adequar o vocabulário à pessoa participante, incentivar o detalhamento das respostas e para muitas pessoas é mais fácil responder oralmente do que escrever, como em um questionário;

- permite a observação da expressão corporal e da tonalidade da voz da(o) entrevistada(o), que têm importante significado para a interpretação das respostas.

\section{Desvantagens:}

- a falta de motivação ou o constrangimento da(o) entrevistada(o) para responder as perguntas, a inadequada compreensão do significado das perguntas devido à insuficiência vocabular e a influência das opiniões pessoais da(o) entrevistador(a) nas respostas.

- o fornecimento de respostas falsas, determinadas por razões conscientes ou inconscientes;

- os custos com o treinamento de pessoal e com a aplicação das entrevistas. 
Considero que as limitações apontadas acima foram, na medida do possível, minimizadas durante esse estudo, visto que todas as pessoas abordadas demonstraram receptividade e boa vontade em participar, e ao realizar a entrevista tive oportunidade de esclarecer o significado das perguntas e motivar o detalhamento das respostas, procurando não direcionar as mesmas. Também não houve custo com o treinamento de entrevistadoras(es), uma vez que todas as entrevistas foram aplicadas e transcritas por uma única pessoa, o que facilitou a padronização das mesmas.

Neste trabalho, o critério para a escolha das(os) participantes foi a amostragem por tipicidade ou intencional. Segundo Gil (1999), este é um tipo de amostragem não probabilística e visa selecionar um subgrupo representativo de uma população com determinadas características. Todos os sujeitos que participaram das entrevistas eram maiores de 18 anos, e residiam em locais adjacentes à área verde da MCAQ há pelo menos 5 anos, exceto duas pessoas do bairro Cidade Aracy, escolhidos por serem antigos moradores e líderes no bairro.

Segundo Bauer e Gaskell (2003), distinguem-se 3 tipos de entrevistas:

a) entrevista de levantamento fortemente estruturada, em que é feita uma série de questões pré-determinadas;

b) entrevista semi-estruturada com um único respondente (entrevista em profundidade);

c) conversação continuada da observação participante, cujo objetivo é absorver o conhecimento local e a cultura por um período de tempo mais longo.

Neste estudo, as entrevistas foram do tipo semi-estruturado com um único respondente (entrevista em profundidade), e cada uma durou cerca de uma hora. De acordo com Bauer e Gaskell (op. cit.), para se determinar o número de entrevistas adequadas em uma pesquisa qualitativa, é importante considerar que "embora as experiências possam parecer únicas ao indivíduo, as representações de tais experiências não surgem de mentes individuais; em alguma medida, elas são o resultado de processos sociais, e são em parte compartilhadas". Portanto, durante as entrevistas é possível perceber que há um número limitado de opiniões ou versões sobre uma determinada realidade. A partir de certo ponto começam a aparecer respostas em comum, até o momento em que é possível constatar que naquele meio social dificilmente aparecerão novas percepções. 
Para a realização das entrevistas com os moradores foi testado um pré-roteiro com três moradoras(es) da microbacia em forma de uma entrevista-piloto. Após a análise dos resultados, o pré-roteiro foi alterado dando origem ao roteiro definitivo para entrevista semi-estruturada utilizado nesta pesquisa (Anexo 1).

O roteiro definitivo é composto por 30 questões e dividido em duas partes: a parte I compreende 15 questões, que referem-se ao levantamento socioeconômico e cultural das(os) participantes. Esta etapa permitiu verificar o perfil das(os) entrevistadas(os), e suas possíveis influências nas relações destas(es) com a área verde, quando as respostas da parte I foram cruzadas com as da parte II;

A segunda parte é composta por 15 questões que abordam as relações das(os) entrevistadas(os) com a área verde da microbacia próxima às suas residências. Nesta segunda parte buscou-se identificar a percepção ambiental dos sujeitos e suas relações de topofilia para com a área verde, além de seu sentimento de pertencimento, seus saberes e seu senso de responsabilidade com relação à atual situação ambiental e ao manejo da área verde.

As entrevistas foram realizadas entre setembro de 2002 e outubro de 2003. A quantidade de entrevistas (40) foi considerada suficiente para a coleta de dados devido à incidência de respostas repetitivas encontradas, indicando ter-se alcançado o estado de representação para a amostra.

Antes do início das entrevistas, os sujeitos foram consultados sobre a disponibilidade para participar, a permissão para o registro das falas com gravador, e foi esclarecido que a intenção do trabalho era o levantamento de opiniões, não havendo, portanto, respostas "certas" ou "erradas".

Como a segunda parte da entrevista trazia questões abrangentes, não foi estabelecido um tempo limite para o término das entrevistas, o que permitiu às(aos) participantes o resgate de histórias sobre a área e a reflexão sobre suas relações com a mesma, em longos diálogos. Essa dinâmica de entrevistas suscitou preciosos depoimentos, que facilitaram a compreensão e a contextualização das relações dos sujeitos com a área enfocada.

Para a obtenção das respostas, a entrevistadora teve a liberdade de explicar com palavras simples o significado das perguntas, mas tendo sempre o máximo cuidado para não interferir nas respostas, mesmo quando solicitada pela(o) entrevistada(o). Procurou 
justificar a não interferência afirmando a necessidade de obtenção da opinião particular da(o) entrevistada(o).

As questões da parte II permitiram uma análise das respostas a partir dos seguintes temas:

- concepções de qualidade ambiental (um bom lugar para se viver na cidade);

- relações entre qualidade de vida e ambiente natural;

- percepção ambiental;

- topofilia;

- saberes locais;

- sentimento de pertença;

- responsabilidade pelo local;

- participação;

- sugestões de manejo.

Durante a sistematização das respostas, procurou-se agrupá-las de modo a enquadrá-las em categorias que, segundo Lüdke e André (1986), facilitam a interpretação e a apresentação dos resultados.

A sistematização das respostas foi composta pelas seguintes etapas:

- audição das entrevistas;

- transcrição completa das entrevistas (exceto de alguns trechos de algumas entrevistas que descrevem aspectos particulares da vida das(os) participantes, e que foram considerados fora do universo da pesquisa), com exemplos apresentados na íntegra no anexo 2;

- tabulação dos dados socioeconômicos (Parte I) e apresentação destes em forma de quadros e gráficos.

- agrupamento das respostas para cada uma das questões da Parte II, de modo a facilitar a comparação das respostas e a elaboração de categorias de agrupamento das mesmas (Anexo 2);

- agrupamento das respostas em categorias específicas, buscando-se os diferentes tipos de percepção ambiental das(os) entrevistadas(os), suas relações de topofilia com a área verde, sentimento de pertença e noções de responsabilidade pelo local. Todas as respostas obtidas estão representadas na apresentação dos resultados, em forma de quadros, gráficos ou tabelas. 
- interpretação das relações entre os dados socioeconômicos e as respostas específicas da Parte II (percepção, topofilia, saberes locais, sentimento de pertencimento e responsabilidade pelo local).

- levantamento das sugestões para o manejo da área verde.

- levantamento de respostas especialmente significativas, que além de compor o agrupamento em categorias, mereceram destaque particular pela sua relevância para o trabalho.

A classificação e organização dos dados foram preparatórias para uma fase mais complexa, na qual procurou-se apresentar os dados de forma clara e coerente, empregando a categorização para ampliar a capacidade de análise dos dados qualitativos obtidos e apresentando-os sob a forma de quadros, gráficos e tabelas.

\subsubsection{MAPA MENTAL E QUESTIONÁRIO}

Para investigar se, para as(os) estudantes, a área de vegetação natural é um elemento significativo da paisagem onde vivem, utilizamos nesta pesquisa a técnica de mapa mental, juntamente com um questionário. Para considerar que a área de vegetação natural é significativa para as(os) participantes, utilizamos como critérios a sua menção com base no mapa mental e o grau de detalhamento da área nas respostas ao questionário. Além disso, o estudo da topofilia e valorização da paisagem foram baseados no conjunto das questões, e o levantamento de sugestões de manejo para a área foi abordado na questão 05 (anexo 04), que era sobre o significado da área para cada participante.

A técnica de mapa mental foi inicialmente utilizada por Lynch em 1960 que operacionalizou o estudo da qualidade visual de cidades americanas. O mapa mental pode ser considerado como um tipo de imagem que reflete o nível icônico da cognição e possui algum tipo de estruturação interna entre seus elementos formadores, remontando a uma lógica operacional. Por meio do mapa mental a mente é capaz de reconstruir um lugar (DEL RIO, 1999).

As três escolas cujas(os) estudantes participaram desta pesquisa foram EE Aracy Leite Pereira Lopes (Vila Monte Carlo), EE Orlando Perez (Cidade Aracy) e EE Maria Ramos (Boa Vista), que se localizam na Microbacia do Córrego da Água Quente, 
próximas à área verde e são freqüentadas por estudantes residentes nos próprios bairros onde se localizam ou em bairros vizinhos.

Como a intenção desta pesquisa foi investigar a percepção e topofilia de pessoas jovens ou adultas, visando obter destas pessoas sugestões de manejo para a área de vegetação, foi escolhida uma turma de terceira série do Ensino Médio do período noturno de cada escola. Todos(as) participantes são maiores de 16 anos e residentes na microbacia há mais de cinco anos.

As atividades com as(os) educandas(os) foram divididas em dois encontros (exceto com o público da EE Orlando Perez, com quem tivemos três encontros), sendo que no primeiro dia houve a aplicação das técnicas de mapa mental e questionário, descritas nos itens a seguir.

\subsubsection{ATIVIDADE COM O MAPA MENTAL}

Inicialmente, a pesquisadora se apresentou (às)aos educandas(os) e explicou que estava realizando um trabalho de percepção sobre o bairro e o entorno, mas sem falar sobre a área verde ou sobre questões ambientais em geral. Também deixou claro que os nomes dos(as) participantes não seriam publicados no trabalho final. Em seguida foram entregues o mapa mental (Anexo 3) e a questão 01 “Observando o mapa mental, descreva o que existe no espaço vazio entre os bairros”, e pediu-se que interpretassem sem limite de tempo. Somente quando terminaram esta primeira resposta, iniciamos a aplicação das próximas questões.

\subsubsection{ATIVIDADE COM O QUESTIONÁRIO}

Ornstein (2001) comenta que a utilização de questionários associados a escalas como a ordinal ou de intervalos tem ocorrido a várias décadas para aferir atitudes, opiniões, níveis de satisfação e eficácia de produtos ou serviços. Há cerca de vinte e cinco anos, têm sido aplicados para coleta de opiniões sobre distintos ambientes construídos, visando medir o grau de satisfação em relação a um determinado ambiente.

A interpretação dos dados obtidos com o questionário permitiu a elaboração de diagnósticos sobre a qualidade ambiental visando a melhoria do ambiente avaliado. 
Essa técnica é composta por um número variado de questões, geralmente apresentadas por escrito, caracterizando um questionário auto-explicado. No caso das questões serem formuladas oralmente pelo(a) pesquisador(a), são chamados questionários aplicados com entrevista (GIL, 1999). O autor também apresenta vantagens e desvantagens no uso desta técnica, apresentadas a seguir:

\section{Vantagens}

- permite atingir grande número de pessoas, ainda que de locais diferentes, em curto espaço de tempo, dá liberdade para responderem no momento que julgarem mais adequado e garante o anonimato destas;

- não exige o treinamento de aplicadores (como ocorre na entrevista) e não expõe as(os) respondentes à influência das(os) pesquisadoras(es).

\section{Desvantagens}

- exclui quem não sabe ler e escrever e impede o auxílio do(a) pesquisador(a) para a compreensão das perguntas;

- não são garantidos o preenchimento e a devolução por todos os sujeitos respondentes, principalmente se houver muitas questões abertas.

Nas escolas, além do mapa mental, foi também utilizado um questionário aplicado com entrevista (GIL, op. cit.), composto por cinco questões abertas e relacionadas entre si, descritas no Anexo 4.

Como cada questão subseqüente poderia direcionar a resposta da anterior, cada uma somente foi entregue após o término da anterior.

Estas questões tiveram como objetivo investigar o conhecimento desse público em relação à área e qual o significado desse local para as(os) estudantes (Percepção Ambiental) e como se relacionam com a área (Topofilia/Topofobia). Além disso, foram levantadas sugestões de manejo para a área.

\subsection{VISITA À ÁREA VERDE COM ESTUDANTES E PROFESSOR(A) DA EE ORLANDO PEREZ}

Além do estudo da percepção, foram realizadas com as(os) participantes da EE Orlando Perez atividades de intervenção educativa in loco, como arrastão ecológico e explicação sobre a biodiversidade local e a qualidade ambiental, com enfoque na 
qualidade da água e nas espécies de plantas medicinais, e explicação sobre as leis ambientais relacionadas à área.

Durante essa visita à área verde foram realizadas as seguintes atividades:

-Apresentação das(os) participantes;

-Apresentação do projeto (justificativa e objetivos);

- Conceituação e dinâmica da bacia hidrográfica (relação entre as atividades desenvolvidas em diferentes pontos da microbacia, sua qualidade ambiental como um todo e a qualidade da água do córrego e nascentes).

- Instruções para o acesso à área verde (silêncio, cuidado onde pisariam, importância da observação dos detalhes da natureza);

- Arrastão ecológico;

- Noções sobre a legislação ambiental relacionada à área.

\subsection{INTERVENÇÃO EDUCATIVA NAS ESCOLAS EE ORLANDO PEREZ E EE MARIA RAMOS PARA SOCIALIZAÇÃO DOS DADOS, SENSIBILIZAÇÃO E SUGESTÕES DE MANEJO}

Em uma etapa subseqüente das intervenções educativas procuramos, a partir de atividades de EA, investigar as mudanças de valores em relação à área verde (topofilia e topofobia), a partir da comparação das antigas e das novas sugestões de manejo da área verde.

Para a sensibilização do público-alvo, nesse encontro foi realizada uma apresentação sobre bacia hidrográfica e especificamente sobre a Microbacia do Córrego da Água Quente, incluindo os tópicos:

- bacia hidrográfica: noções sobre a dinâmica da microbacia, sempre com base nos dados obtidos durante a pesquisa e com a utilização de uma maquete (Anexo 5) para facilitar a compreensão da topografia da microbacia;

- água: apresentação dos dados de qualidade da água coletados nesta pesquisa e a importância da microbacia como área de mananciais;

- paisagem: apresentação de fotos e maquete da microbacia, enfatizando a questão do relevo e de suas modificações resultantes da presença de impactos ambientais; 
- biodiversidade: presença de fauna e flora com espécies características dos ecossistemas cerrado, cerradão e mata ciliar, ameaçadas de extinção e com propriedades medicinais;

- interpretação dos resultados do mapa mental e questionários previamente aplicados com o mesmo público para o levantamento da percepção;

- principais impactos ocorridos na área verde, sendo enfatizados: queimadas, desmatamento, erosão, assoreamento do córrego, presença de resíduos sólidos e efluentes domésticos e a caça e comercialização de animais silvestres.

Após a apresentação das características da microbacia, visando a informação e a sensibilização, foi realizada uma plenária em que as(os) participantes expuseram suas opiniões sobre os itens supracitados e, em grupos de cerca de quatro pessoas, redigiram suas novas sugestões para o manejo da área. 
5 RESULTADOS

\section{CARACTERIZAÇÃo E PERCEPÇÃO AMBIENTAIS DA ÁREA VERDE DA MICROBACIA DO CÓRREGO DA ÁGUA QUENTE}

\subsection{CARACTERIZAÇÃO AMBIENTAL DA ÁREA VERDE DA MICROBACIA DO CÓRREGO DA ÁGUA QUENTE}

A MCAQ possui uma área verde de $3.165 .740,57 \mathrm{~m}^{2}$, adjacente aos bairros Jardim das Torres, Jardim Medeiros, Jardim Beatriz, Mirante da Bela Vista, Jardim Santa Teresa, Jardim Social Belvedere, Jardim Pacaembu, Jardim das Rosas, Jardim Gonzaga, Vila Monte Carlo, Cidade Aracy e Loteamento Social Antenor Garcia, e banhada pelo Córrego da Água Quente e suas nascentes.

Dentre estes bairros, quatro foram escolhidos para o levantamento da percepção ambiental da população através de entrevistas (Jardim Gonzaga, Antenor Garcia, Vila Monte Carlo e Jardim Pacaembu) e estão destacados na Figura 10 (página 70). Em relação à percepção ambiental das(os) estudantes, participaram pessoas de quase todos os bairros da bacia.

A seguir, estão duas vistas panorâmicas da área verde da MCAQ (Figura 20). 


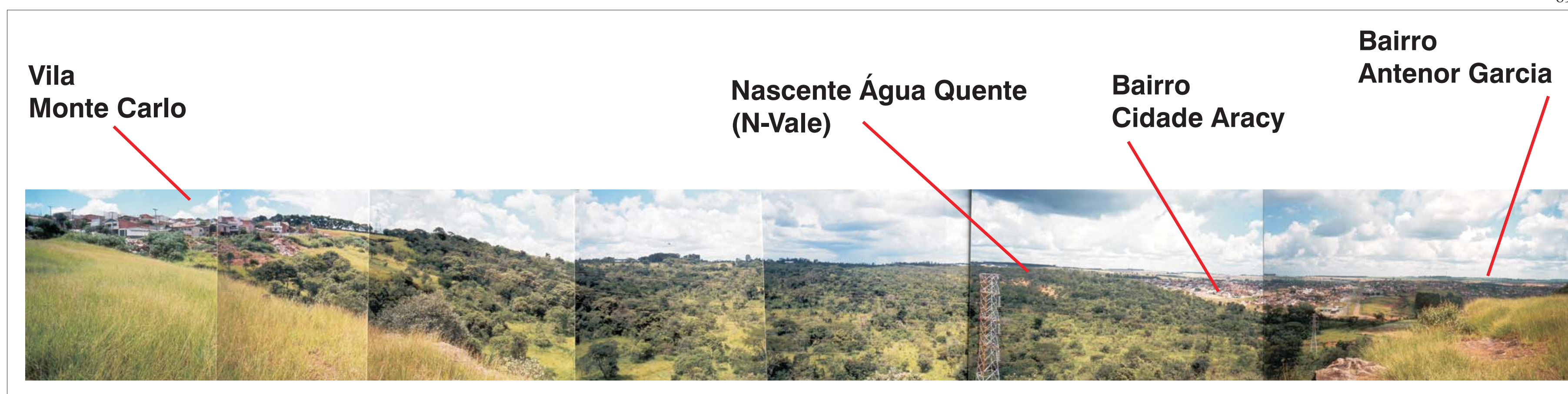

\section{Bairro}

Jardim Gonzaga

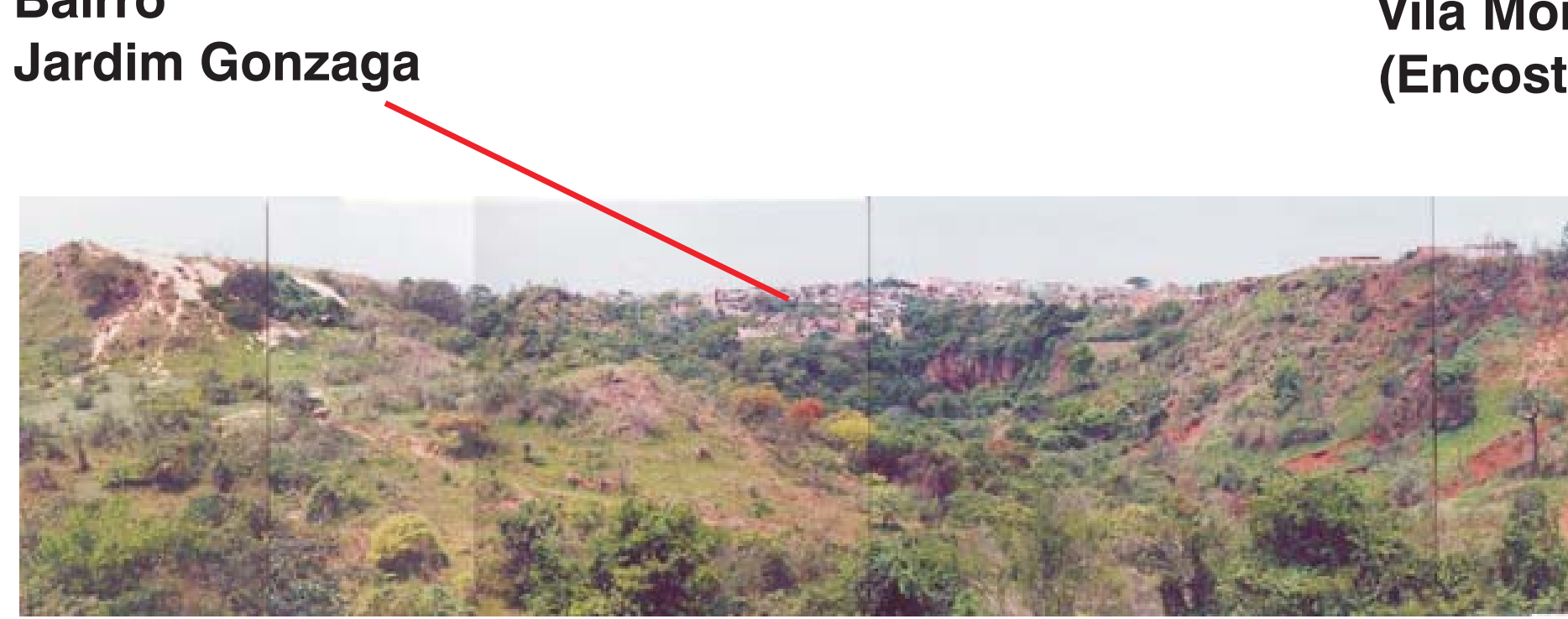

Vila Monte Carlo

(Encosta) 
As rochas da Formação Botucatu, como as localizadas na porção sul do município, banhada pelo Córrego da Água Quente, formam uma importante área de recarga do aqüífero, e de acordo com Aguiar (1988) o pH das águas subterrâneas é em média 6,2 .

Os arenitos Botucatu são responsáveis pelas superfícies de topografia quase plana e vegetação típica de campo e campo cerrado. Esta monotonia é truncada pela presença de escarpas abruptas e de morros testemunhos (GONÇALVES, 1986). Essas variações podem ser observadas na área verde da microbacia, que possui alguns trechos de relevo bastante acidentado, onde a topografia íngreme é sustentada por afloramentos rochosos, resultante de entalhamento do relevo por processos erosivos intensos ao longo das drenagens que aí se instalaram.

\subsubsection{AVIFAUNA DA ÁREA VERDE}

Em relação à fauna da MCAQ, havia somente um levantamento da avifauna do ano de 2002 em que foram encontradas 57 espécies (de acordo com o Anexo 6), e que integra o relatório de Impacto Ambiental do Projeto Habitar Brasil BID (TÓROTONISSI e TONISSI, 2002).

Nesta pesquisa realizamos dois levantamentos de avifauna nos dias 26/02/2005 no período da tarde (a partir das 13:30h), e 22/04/2005, pela manhã (a partir das 7:00h), ambos com 3 horas de duração.

Em relação ao horário dos dois levantamentos, foi possível encontrar 29 espécies na observação realizada no período vespertino e 47 pela manhã. Portanto, acreditamos que o período da manhã seja mais adequado para atividades de EA na área verde com enfoque na observação da avifauna local, havendo necessidade de verificação se essa condição se repete ao longo do ano. Além desses dois levantamentos específicos, mais algumas espécies foram encontradas no decorrer das visitas à área para outras atividades relacionadas ao projeto de pesquisa (coleta de água, identificação de espécies vegetais, atividade com estudantes) e essas espécies estão incluídas no Quadro 2 a seguir totalizando 64 espécies. Esses resultados sobre avifauna também estão mostrados na parte que trata sobre percepção ambiental, em uma comparação dos resultados dos levantamentos com as percepções e saberes da comunidade. As identificações seguiram Höfling e Camargo (2002), Silva (1998), Sick (1997), Motta-Junior e Vasconcellos (1996), Carvalho (1995) e Motta-Junior (1990). 


\begin{tabular}{|c|c|c|c|}
\hline Nome científico & $\begin{array}{c}\text { Nome } \\
\text { comum }\end{array}$ & Ordem & Família \\
\hline $\begin{array}{l}\text { Crypturellus } \\
\text { parvirostris }\end{array}$ & $\begin{array}{l}\text { Inhambu- } \\
\text { chororó }\end{array}$ & TINAMIFORMES & Tinamidae \\
\hline $\begin{array}{l}\text { Phalacrocorax } \\
\text { brasilianus }\end{array}$ & Biguá-uma & PELECANIFORMES & Phalacrocoracidae \\
\hline Egretta tula & $\begin{array}{l}\text { Garça-branca- } \\
\text { pequena }\end{array}$ & CICONIIFORMES & Ardeidae \\
\hline Casmerodius albus & Garça-grande & CICONIIFORMES & Ardeidae \\
\hline Coragyps atratus & Urubu-preto & CICONIIFORMES & Cathartidae \\
\hline $\begin{array}{l}\text { Dendrocygna } \\
\text { viduata }\end{array}$ & Irerê & ANSERIFORMES & Anatidae \\
\hline Polyborus plancus & $\begin{array}{l}\text { Caracará- } \\
\text { comum }\end{array}$ & FALCONIFORMES & Falconidae \\
\hline Milvago chimachima & Carrapateiro & FALCONIFORMES & Falconidae \\
\hline $\begin{array}{l}\text { Penelope } \\
\text { superciliaris }\end{array}$ & Jacupeba & GALLIFORMES & Cracidae \\
\hline Aramides cajanea & $\begin{array}{l}\text { Saracura-três- } \\
\text { potes }\end{array}$ & GRUIFORMES & Rallidae \\
\hline Gallinula chloropus & $\begin{array}{l}\text { Galinha- } \\
\text { d'água }\end{array}$ & GRUIFORMES & Rallidae \\
\hline Cariama cristata & $\begin{array}{l}\text { Seriema-de- } \\
\text { pé-vermelho }\end{array}$ & GRUIFORMES & Cariamidae \\
\hline Vanellus chilensis & Quero-quero & CHARADRIIFORMES & Charadriidae \\
\hline $\begin{array}{ll}\begin{array}{l}\text { Columba } \\
\text { domestica }\end{array} & \text { livia } \\
\end{array}$ & $\begin{array}{l}\text { Pombo } \\
\text { doméstico }\end{array}$ & COLUMBIFORMES & Columbidae \\
\hline Columba picazuro & Asa-branca & COLUMBIFORMES & Columbidae \\
\hline Leptotila rufaxilla & $\begin{array}{l}\text { Juriti- } \\
\text { gemedeira, } \\
\text { gemedeira }\end{array}$ & COLUMBIFORMES & Columbidae \\
\hline Columbina talpacoti & $\begin{array}{l}\text { Rolinha- } \\
\text { caldo-de- } \\
\text { feijão }\end{array}$ & COLUMBIFORMES & Columbidae \\
\hline \multirow[t]{2}{*}{$\begin{array}{l}\text { Scardafella } \\
\text { squammata }\end{array}$} & $\begin{array}{l}\text { Rolinha-fogo- } \\
\text { apagou }\end{array}$ & COLUMBIFORMES & Columbidae \\
\hline & $\begin{array}{l}\text { Rolinha- } \\
\text { pequena- } \\
\text { doméstica }\end{array}$ & COLUMBIFORMES & Columbidae \\
\hline Pionus maximiliani & $\begin{array}{l}\text { Maitaca- } \\
\text { verde }\end{array}$ & PSITTACIFORMES & Psittacidae \\
\hline \multirow[t]{2}{*}{ Amazona aestiva } & $\begin{array}{l}\text { Papagaio- } \\
\text { curau }\end{array}$ & PSITTACIFORMES & Psittacidae \\
\hline & $\begin{array}{l}\text { Periquito-de- } \\
\text { encontro- } \\
\text { vermelho }\end{array}$ & PSITTACIFORMES & Psittacidae \\
\hline Brotogeris chiriri & $\begin{array}{l}\text { Periquito-de- } \\
\text { encontro- } \\
\text { amarelo }\end{array}$ & PSITTACIFORMES & Psittacidae \\
\hline
\end{tabular}




\begin{tabular}{|c|c|c|c|}
\hline \multicolumn{4}{|c|}{ Quadro 2: Avifauna da área verde da MCAQ. (continuação) } \\
\hline Nome científico & $\begin{array}{c}\text { Nome } \\
\text { comum }\end{array}$ & Ordem & Família \\
\hline Crotophaga ani & Anu-preto & CUCULIFORMES & Cuculidae \\
\hline Guira guira & Anu-branco & CUCULIFORMES & Cuculidae \\
\hline Tapera naevia & $\begin{array}{l}\text { Saci-do- } \\
\text { campo }\end{array}$ & CUCULIFORMES & Cuculidae \\
\hline Speotyto cunicularia & $\begin{array}{l}\text { Coruja- } \\
\text { buraqueira }\end{array}$ & STRIGIFORMES & Strigidae \\
\hline $\begin{array}{l}\text { Eupetomena } \\
\text { macroura }\end{array}$ & $\begin{array}{l}\text { Beija-flor- } \\
\text { tesoura }\end{array}$ & TROCHILIFORMES & Trochilidae \\
\hline Colibri serrirostris & $\begin{array}{l}\text { Beija-flor-de- } \\
\text { orelha-violeta }\end{array}$ & TROCHILIFORMES & Trochilidae \\
\hline Phaethornis pretrei & $\begin{array}{l}\text { Rabo-branco- } \\
\text { acanelado }\end{array}$ & TROCHILIFORMES & Trochilidae \\
\hline Ramphastos toco & Tucanuçu & PICIFORMES & Ramphastidae \\
\hline Colaptes campestris & $\begin{array}{l}\text { Pica-pau-do- } \\
\text { campo }\end{array}$ & PICIFORMES & Picidae \\
\hline $\begin{array}{l}\text { Campephilus } \\
\text { melanoleucos }\end{array}$ & $\begin{array}{l}\text { Pica-pau-de- } \\
\text { topete- } \\
\text { vermelho }\end{array}$ & PICIFORMES & Picidae \\
\hline Picamnus cirratus & $\begin{array}{l}\text { Pica-pau- } \\
\text { barrado-anão }\end{array}$ & PICIFORMES & Picidae \\
\hline Celeus flavescens & $\begin{array}{l}\text { Pica-pau- } \\
\text { amarelo }\end{array}$ & PICIFORMES & Picidae \\
\hline $\begin{array}{l}\text { Thamnophilus } \\
\text { doliatus }\end{array}$ & $\begin{array}{l}\text { Choca- } \\
\text { barrada }\end{array}$ & PASSERIFORMES & Formicariidae \\
\hline $\begin{array}{l}\text { Thamnophilus } \\
\text { punctatus }\end{array}$ & $\begin{array}{l}\text { Choca-bate- } \\
\text { rabo }\end{array}$ & PASSERIFORMES & Formicariidae \\
\hline Furnarius rufus & João-de-barro & PASSERIFORMES & Furnariidae \\
\hline $\begin{array}{l}\text { Pitangus } \\
\text { sulphuratus }\end{array}$ & Bem-te-vi & PASSERIFORMES & Tyrannidae \\
\hline $\begin{array}{l}\text { Tyrannus } \\
\text { melancholicus }\end{array}$ & Suiriri & PASSERIFORMES & Tyrannidae \\
\hline $\begin{array}{l}\text { Arundinicola } \\
\text { leucocephala }\end{array}$ & $\begin{array}{l}\text { Maria- } \\
\text { viuvinha }\end{array}$ & PASSERIFORMES & Tyrannidae \\
\hline Antilophia galeata & Soldadinho & PASSERIFORMES & Pipridae \\
\hline $\begin{array}{l}\text { Notiochelidon } \\
\text { cyanoleuca }\end{array}$ & $\begin{array}{l}\text { Andorinha- } \\
\text { pequena-de- } \\
\text { casa }\end{array}$ & PASSERIFORMES & Hirundinidae \\
\hline $\begin{array}{l}\text { Stelgidopteryx } \\
\text { ruficollis }\end{array}$ & $\begin{array}{l}\text { Andorinha- } \\
\text { serradora-do- } \\
\text { sul }\end{array}$ & PASSERIFORMES & Hirundinidae \\
\hline $\begin{array}{l}\text { Cyanocorax } \\
\text { cristatellus }\end{array}$ & $\begin{array}{l}\text { Gralha-do- } \\
\text { cerrado }\end{array}$ & PASSERIFORMES & Corvidae \\
\hline Troglodytes aedon & Corruíra & PASSERIFORMES & Troglodytidae \\
\hline Coereba flaveola & Cambacica & PASSERIFORMES & Troglodytidae \\
\hline Thraupis sayaca & $\begin{array}{l}\text { Sanhaço- } \\
\text { cinzento }\end{array}$ & PASSERIFORMES & Troglodytidae \\
\hline
\end{tabular}




\begin{tabular}{|c|c|c|c|}
\hline \multicolumn{4}{|c|}{ Quadro 2: Avifauna da área verde da MCAQ. (continuação) } \\
\hline Nome científico & $\begin{array}{c}\text { Nome } \\
\text { comum }\end{array}$ & Ordem & Família \\
\hline Tangara cayana & Saíra-amarela & PASSERIFORMES & Troglodytidae \\
\hline Turdus leucomelas & $\begin{array}{l}\text { Sabiá- } \\
\text { barranco }\end{array}$ & PASSERIFORMES & Muscicapidae \\
\hline Turdus rufiventris & $\begin{array}{l}\text { Sabiá- } \\
\text { laranjeira }\end{array}$ & PASSERIFORMES & Muscicapidae \\
\hline Mimus saturninus & $\begin{array}{l}\text { Tejo-do- } \\
\text { campo }\end{array}$ & PASSERIFORMES & Mimidae \\
\hline $\begin{array}{l}\text { Sporophila } \\
\text { leucoptera }\end{array}$ & Patativa & PASSERIFORMES & Fringillidae \\
\hline Sicalis flaveola & $\begin{array}{l}\text { Canário-da- } \\
\text { terra }\end{array}$ & PASSERIFORMES & Fringillidae \\
\hline Euphonia chlorotica & Vi-vi & PASSERIFORMES & Emberizidae \\
\hline Tangara cayana & Saíra-cabocla & PASSERIFORMES & Emberizidae \\
\hline $\begin{array}{l}\text { Sporophila } \\
\text { caerulescens }\end{array}$ & Coleirinha & PASSERIFORMES & Emberizidae \\
\hline Zonotrichia capensis & Tico-tico & PASSERIFORMES & Emberizidae \\
\hline $\begin{array}{l}\text { Coryphospingus } \\
\text { cucullatus }\end{array}$ & $\begin{array}{l}\text { Tico-tico-rei- } \\
\text { vermelho }\end{array}$ & PASSERIFORMES & Emberizidae \\
\hline Volatinia jacarina & Tiziu & PASSERIFORMES & Emberizidae \\
\hline Passerina brissoni & $\begin{array}{l}\text { Azulão- } \\
\text { verdadeiro }\end{array}$ & PASSERIFORMES & Emberizidae \\
\hline $\begin{array}{l}\text { Molothrus } \\
\text { banariensis }\end{array}$ & Chupim & PASSERIFORMES & Emberizidae \\
\hline Gnorimopsar chopi & Pássaro-preto & PASSERIFORMES & Emberizidae \\
\hline Passer domesticus & $\begin{array}{l}\text { Pardal- } \\
\text { doméstico }\end{array}$ & PASSERIFORMES & Ploceidade \\
\hline
\end{tabular}

Quadro 2: Avifauna da área verde da Microbacia do Córrego da Água Quente.

As baixas densidades populacionais das aves relacionam-se diretamente com a degradação da vegetação dos seus habitats, de onde obtêm alimento, abrigo e material para a construção de ninhos (MOTTA-JUNIOR e LOMBARDI, 1990). Destarte, as aves estão entre os taxa considerados como bons bioindicadores da qualidade ambiental (REGALADO e SILVA, 1997), e entre os mais prováveis de desaparecerem em áreas fragmentadas como essa área verde, devido à acelerada modificação da paisagem local.

No atual levantamento foram encontradas 31 espécies diferentes daquelas relacionadas no relatório de 2002, com destaque para Antilophia galeata (soldadinho), que de acordo com Regalado et al (2000) é considerada como espécie em perigo de extinção.

Várias das espécies registradas apresentam hábitos de consumir frutos pelo menos esporadicamente, e muitas delas como Pitangus sulphuratus (bem-te-vi), 
Leptotila rufaxilla (juriti-gemedeira), Brotogeris chiriri (periquito-de-encontroamarelo), Tyrannus melancholicus (suiriri) e Turdus leucomelas (sabiá-barranco), têm sido consideradas como importantes dispersoras de sementes das espécies de plantas nativas e podem estar contribuindo para a regeneração natural da área.

A recuperação da diversidade e riqueza da fauna pode estar relacionada, além da caça predatória e de outras formas de agressão humana, também à capacidade de suporte do meio. Considerando-se as populações de um ecossistema, capacidade de suporte significa a capacidade desse ambiente suportar um número de indivíduos limitado pela quantidade de algum tipo de recurso ambiental - considerado então como o fator limitante (WITTHAKER, 1975). O aumento da capacidade de suporte através do fornecimento de alimentos (introdução de mais espécies frutíferas de rápido crescimento, por exemplo), a construção de abrigos artificiais, o controle de espécies exóticas predadoras ou competidoras, entre outros, pode contribuir para o aumento da população das espécies desejadas.

Pegoraro e Machado (1992) realizaram as primeiras observações referentes à comunidade de aves aquáticas da região do reservatório de Salto Grande (AmericanaSP) e organizaram um registro fotográfico das espécies encontradas. Esse tipo de documento é bastante útil em projetos de EA. Segundo Ishikawa-Ferreira e RibeiroNeto (2004) prefeituras e entidades não-governamentais também têm se valido da diversidade da avifauna para estimular a observação e o interesse de estudantes pela preservação do ambiente na bacia do Rio Atibaia.

Embora neste estudo não tenhamos levado em conta a sazonalidade da amostragem nem realizado um levantamento quantitativo, constatamos que na área verde ainda podem ser encontradas algumas espécies de aves que, por serem consideradas belas ou devido à sua raridade, podem ser utilizadas como espéciesbandeira em projetos de EA, como Coryphospingus cucullatus (tico-tico-rei-vermelho), Campephilus melanoleucos (pica-pau-de-topete-vermelho), Ramphastos toco (tucanuçu), Amazona aestiva (papagaio-curau) e Penelope superciliaris (jacupeba).

\subsubsection{VEGETAÇÃO DA ÁREA VERDE}

No estado de São Paulo, a vegetação de cerrado ocupava, originalmente, cerca de $14 \%$ do território, distribuída em manchas descontínuas ao longo da depressão 
periférica e em todo o planalto ocidental paulista (SÃO PAULO, 1997). Em toda essa região, a vegetação original era constituída por floresta estacional semidecidual e cerrado, sendo que este último compunha as áreas de solo mais ácido, com menor fertilidade e elevado teor de alumínio, e considerada de má qualidade para a agricultura durante muito tempo.

Leitão-Filho (1992) relatou que, segundo dados de Borgonovi e Chiarini (1965) (citados pelo autor), em 1962 os cerrados abrangiam, $33.929 \mathrm{~km}^{2}$ da área do estado. E de acordo Serra-Filho et al. (1975) em 1973, esse valor caiu para $10.388 \mathrm{~km}^{2}$. Já em 1992, Kronka et al. (1998) encontraram uma área total remanescente de apenas 2.379 $\mathrm{km}^{2}$ de cerrado, demonstrando a acelerada destruição desse bioma no Estado. Rodrigues e Leitão-Filho (2000) destacam a rápida devastação desse ecossistema e Durigan et al. (2003), por sua vez, alertam para o fato de que a vegetação de cerrado no Estado de São Paulo em 2003 cobria menos de 7\% da sua área original e que estava restrita apenas na forma de fragmentos isolados. Esses dados mostram a urgente necessidade de preservação de áreas remanescentes de cerrados no Estado de São Paulo, mesmo aquelas de pequenas dimensões, que ocorrem isoladamente em algumas regiões (LEITÃO-FILHO, op. cit.), como é o caso do remanescente existente na MCAQ.

De acordo com Durigan et al. (2002), a vegetação do cerrado no Estado de São Paulo foi bastante estudada nas décadas de 70 e 80, mas com raras exceções os trabalhos no Cerrado restringem-se ao estrato arbóreo.

A maioria dos remanescentes de vegetação de cerrado são áreas do Governo do Estado de São Paulo, particularmente as Estações Ecológicas de Moji-Guaçu, Jataí e Itirapina, sendo que a última bastante próxima do município de São Carlos. Durigan et al. (1999) que estudaram os fragmentos de cerrado da Estação Ecológica de Assis, relataram que nesta estação o cerrado foi integralmente protegido nos últimos 30 anos.

Durigan et al. (op. cit.) utilizaram as definições de vários autores (RIBEIRO e WALTER, 1998; WATANABE 1997; LEITÃO-FILHO, 1982; EITEN 1972; EITEN, 1970 e RIZZINI, 1963) para classificar os tipos vegetacionais mais comuns na região de Assis, estado de São Paulo, divididos como:

- cerrado: formação vegetal com dossel geralmente inferior a $7 \mathrm{~m}$ de altura, com estrato arbustivo fechado ou semi-aberto, geralmente com menos de $3 \mathrm{~m}$ de altura no dossel. O cerrado (sensu strictu) é representado pela existência de árvores e arbustos de médio e pequeno porte esparsamente distribuídos, o que permite a insolação do extrato herbáceo associado. É uma fisionomia de alto índice de diversidade, composta por 
espécies de formação escleromórfica e aparência árida. Essa característica é resultado de adaptações às condições edáficas existentes - toxicidade do solo em razão do teor de alumínio trocável e existência de períodos de déficit hídrico durante o ano.

- cerradão: formação florestal com aspectos xeromórficos, composta por arbóreas de medianas a altas, com um dossel fechado ou semi-aberto, mas não esparso. Do ponto de vista fisionômico é uma floresta, mas floristicamente é mais similar ao cerrado;

- mata ciliar: formação florestal que possui características próprias e ocorre em locais sujeitos a influências do lençol freático ou de inundações periódicas, podendo não apresentar transição evidente para outras físionomias como a mata seca e o cerradão.

Na MCAQ a vegetação original era composta por cerrado, e inclusive onde hoje resta a área verde predominava o Cerrado, caracterizado por espécies herbáceoarbustivas, com árvores perenifólias Além do cerrado, a cobertura vegetal primitiva era também composta por Cerradão, mas já em 1985, este já se encontrava degradado (GONÇALVES, 1986; LORANDI,1985). Também ocorriam trechos de Mata-galeria ao longo dos corpos d'água e, onde havia a exposição de camadas de basalto proporcionando um solo mais fértil, era observada vegetação de Floresta Estacional Semidecídua.

Essa vegetação foi fortemente modificada pela ação antrópica, o que facilitou de maneira drástica os processos erosivos bastante evidenciados na área (AGUIAR, 1988). Já em 1988, este autor pôde constatar que a cobertura vegetal dessa área era pouco adensada e altamente impactada pela interferência humana, o que acentuava a erosão.

Atualmente, a área verde encontra-se esparsamente coberta por flora nativa composta por formações vegetais distintas, compondo um mosaico de acordo com as condições de solo e umidade locais. Sob uma óptica geral, é possível enumerar dois tipos vegetacionais de ocorrência na região: o cerrado e a floresta de transição. $\mathrm{Na}$ área de estudo, o cerrado ocorre nas zonas cujo substrato é a areia quartzosa consorciada com o latossolo amarelo-álico situados, principalmente, no fundo e no topo das encostas (LORANDI, 1985). A floresta de transição é representada pela mescla de espécies da Floresta Estacional Semidecídua com espécies de Cerradão e de Mata Ciliar. Essa composição de espécies é fruto da existência de zonas de tensão ecológica em que a variação nas condições locais de solo e umidade propicia ambientes ecologicamente distintos. Assim, as diferentes espécies vegetais possuem adaptações que as habilitam 
ocupar nichos diferenciados. A altura das essências arbóreas da floresta de transição varia entre $5 \mathrm{~m}$ e $20 \mathrm{~m}$.

A partir da caracterização da flora da bacia realizada para a elaboração do Relatório de Impacto Ambiental do Projeto Habitar Brasil BID (TÓRO-TONISSI e TONISSI, 2002), foram identificadas 24 espécies descritas no Anexo 7.

Atualmente, os fragmentos de vegetação nativa da área verde da bacia, em sua maioria, estão bastante impactados por resíduos sólidos e efluentes domésticos. A área é freqüentemente utilizada pelas(os) moradoras(es) como espaço de lazer, via de acesso entre os bairros adjacentes, pastagem para gado bovino e eqüino, e até mesmo como ponto de captação de água para consumo humano. Nas margens do Córrego da Água Quente, houve grande remoção de mata ciliar e hoje a área caracteriza-se por uma vegetação mais aberta (arbórea, arbustiva e rasteira), extremamente impactada, favorecendo os processos erosivos. Sé (1992) ao estudar a Bacia Hidrográfica do Monjolinho, na qual está inserida a Microbacia do Água Quente, também detectou uma acentuada diminuição e fragmentação dos ecossistemas primitivos por interferência antrópica, notando que a vegetação original vem sendo substituída por atividades agrícolas e pela mancha urbana. No caso da MCAQ, predominou a degradação pelo acelerado e desordenado crescimento da mancha urbana.

Apesar de ser evidente essa diminuição e fragmentação da vegetação da área verde da microbacia, nesse estudo não tivemos o objetivo de quantificar as espécies existentes na área verde, mas de encontrar espécies cujas características denotam que são interessantes para serem utilizadas em projetos educativos, seja pelas suas interações ecológicas no próprio ecossistema, seja pelos possíveis usos pelo ser humano.

A partir dos levantamentos realizados em excursões assistemáticas na área verde, e dos três levantamentos realizados com o Sr. Antônio de Oliveira, residente no Jardim Gonzaga, foram identificadas 66 espécies entre arbóreas, arbustivas, herbáceas e trepadeiras (conforme divisão sugerida por Durigan, 1999), descritas no Quadro 3. 


\begin{tabular}{|c|c|c|}
\hline Nome científico & Nome comum & Família \\
\hline Açoita-cavalo & Luehea paniculata & Tiliaceae \\
\hline $\begin{array}{l}\text { Alecrim-do-campo, } \\
\text { vassourinha }\end{array}$ & Baccharis dracunculifolia & Asteraceae \\
\hline Amarelinho & Maclura tinctoria & Moraceae \\
\hline $\begin{array}{l}\text { Ananás, abacaxi-do- } \\
\text { cerrado }\end{array}$ & Ananas ananassoides & Bromeliaceae \\
\hline Angico-do-cerrado & Adenanthera falcata & Mimosaceae \\
\hline Araruva, araribá & Centrolobium tomentosum & LeguminosaePapilionoideae \\
\hline $\begin{array}{l}\text { Araticum-do-campo, } \\
\text { marolo }\end{array}$ & Annona coriacea & Annonaceae \\
\hline $\begin{array}{l}\text { Araticum-do-campo, } \\
\text { marolo }\end{array}$ & Annona crassiflora & Annonaceae \\
\hline Assa-peixe & Vernonia polyanthes & Asteraceae \\
\hline Barbatimão-falso & Dimorphandra mollis & Mimosaceae \\
\hline $\begin{array}{c}\text { Barbatimão, Barbatimão } \\
\text { verdadeiro }\end{array}$ & $\begin{array}{c}\text { Stryphnodendron } \\
\text { adstringens }\end{array}$ & Mimosaceae \\
\hline Batata-de-purga & Operculina alata & Convolvulaceae \\
\hline Cajuzinho-do-campo & Anacardium humile & Anacardiaceae \\
\hline Cambará & Gochnatia polymorpha & Compositae \\
\hline Cambuí & Myrcia multiflora & Myrtaceae \\
\hline Canela-de-veado & Helietta apiculata & Lauraceae \\
\hline Canelão-amarelo & Ocotea velutina & Lauraceae \\
\hline Canelinha & Nectandra megapotamica & Lauraceae \\
\hline Caraguatá & Bromelia balansae & Bromeliaceae \\
\hline Carobinha-do-campo & Jacaranda peteroides & Bignoniaceae \\
\hline Caruru, amaranto-verde & Amaranthus viridis & Amaranthaceae \\
\hline Cedro-branco & Guarea guidonia & Meliaceae \\
\hline Cedro-vermelho & Cedrella fissilis & Meliaceae \\
\hline Cinzeiro, caixeta & Vochysia tucanorum & Vochysiaceae \\
\hline Cipó-São-João & Pyrostegia venusta & Bignoniaceae \\
\hline Copaíba, pau-de-óleo & Copaifera langsdorffii & Caesalpiniaceae \\
\hline Erva-de-bicho-roxa & Polygonum acuminatum & Polygonaceae \\
\hline Erva-de-rato & Asclepias sp & Asclepiadaceae \\
\hline Farinha-seca & Albizia hasslerii & Mimosoideae \\
\hline $\begin{array}{l}\text { Guabiroba, guabiroba-do- } \\
\text { campo }\end{array}$ & $\begin{array}{c}\text { Campomanesia } \\
\text { adamantium }\end{array}$ & Myrtaceae \\
\hline Gervão & Verbena bonariensis & Verbenaceae \\
\hline Gervão-azul & Stachytarpheta sp. & Verbenaceae \\
\hline Goiabeira & Psidium guajava & Myrtaceae \\
\hline Goiaba-do-campo & Acca sellowiana & Myrtaceae \\
\hline Ipê-amarelo-do-cerrado & Tabebuia aurea & Bignoniaceae \\
\hline Ipê-roxo & Tabebuia avellanedae & Bignoniaceae \\
\hline Jacarandá-paulista & Machaerium villosum & Fabaceae \\
\hline Jatobá & Hymenaea courbaril & Caesalpiniaceae \\
\hline Jequitibá-rosa & Cariniana legalis & Lecythidaceae \\
\hline Juá-bravo & Solanum viarum & Solanaceae \\
\hline
\end{tabular}




\begin{tabular}{|c|c|c|}
\hline \multicolumn{3}{|c|}{$\begin{array}{l}\text { Quadro 3: Espécies vegetais dos fragmentos de cerrado, cerradão e floresta } \\
\text { estacional semidecídua da área verde da MCAQ (continuação). }\end{array}$} \\
\hline Nome científico & Nome comum & Família \\
\hline Jurubeba & Solanum paniculatum & Solanaceae \\
\hline Leiteiro & Sapium glandulatum & Euphorbiaceae \\
\hline Limão-bravo & Siparuna guianensis & Monimiaceae \\
\hline Língua-de-vaca & Elephantopus mollis & Asteraceae \\
\hline Lobeira, fruta-de-lobo & Solanum lycocarpum & Solanaceae \\
\hline Mama-de-cadela & Brosimum gaudichaudii & Moraceae \\
\hline Mamica-de-porca & $\begin{array}{l}\text { Zanthoxylum } \\
\text { hasslerianum }\end{array}$ & Rutaceae \\
\hline Marfim, pau-marfim & $\begin{array}{l}\text { Balfourodendron } \\
\text { riedelianum }\end{array}$ & Rutaceae \\
\hline $\begin{array}{l}\text { Marmelada-de-cachorro, } \\
\text { marmelinho }\end{array}$ & Alibertia sessilis & Rubiaceae \\
\hline Melão-de-São-Caetano & Momordica charantia & Cucurbitaceae \\
\hline Mutambo & Guamuza ulmifolia & Sterculiaceae \\
\hline Olho-de-cabra, tento & Ormosia arborea & LeguminosaePapilionoideae \\
\hline Olho-de-boi & Mucuna altissima & Rutaceae \\
\hline $\begin{array}{l}\text { Pata-de-vaca, unha-de- } \\
\text { vaca }\end{array}$ & Bauhinia forficata & Caesalpiniaceae \\
\hline Pau-de-espeto, espeteiro & Casearia gossypiosperma & Flacourtiaceae \\
\hline Peroba-do-campo & $\begin{array}{c}\text { Aspidosperma } \\
\text { tomentosum }\end{array}$ & Apocynaceae \\
\hline Picão-preto & Bidens pilosa & Asteraceae \\
\hline Pimenta-de-macaco & Xylopia aromatica & Annonaceae \\
\hline Piqui & Caryocar brasiliense & Caryocaraceae \\
\hline Quaresmeira-do-cerrado & Tibouchina stenocarpa & Melastomataceae \\
\hline Quina-cruzeira & Strychnos pseudo-quina & Loganiaceae \\
\hline Sangra-d'água, drago & Croton urucurana & Euphorbiaceae \\
\hline Sapuva & Machaerium brasiliense & Fabaceae \\
\hline Sucupira, sucupira-branca, & Pterodon emarginatus & Fabaceae \\
\hline Urtiga, urtigão & Urtica dioica & Urticaceae \\
\hline
\end{tabular}

Quadro 3: Espécies vegetais dos fragmentos de cerrado, cerradão e floresta estacional semidecídua da área verde da MCAQ.

Várias dessas espécies se destacam pelas suas propriedades medicinais, como Baccharis dracunculifolia e Stryphnodendron adstringens (ambas na figura 23), Bromelia balansae (figura 21), Strychnos pseudo-quina (figura 23), por servirem de alimento para a fauna e/ou para o ser humano, como Campomanesia adamantium, Annona coriacea (figura 22), Solanum lycocarpum e Caryocar brasiliense, ou por serem consideradas ornamentais e indicadas para a arborização urbana, como Xylopia aromatica, Vochysia tucanorum e Cedrella fissilis (as três últimas na figura 24).

Em relação à arborização urbana, defendemos a preferência pelas espécies nativas, por atenderem à demanda alimentícia principalmente da avifauna urbana, e 
acreditamos que projetos de Educação Ambiental junto à comunidade e às escolas podem esclarecer sobre a importância da arborização com espécies nativas, além de possibilitar que a comunidade conheça a diversidade de espécies alimentícias do cerrado, como mais uma estratégia de valorização para a conservação deste ecossistema.

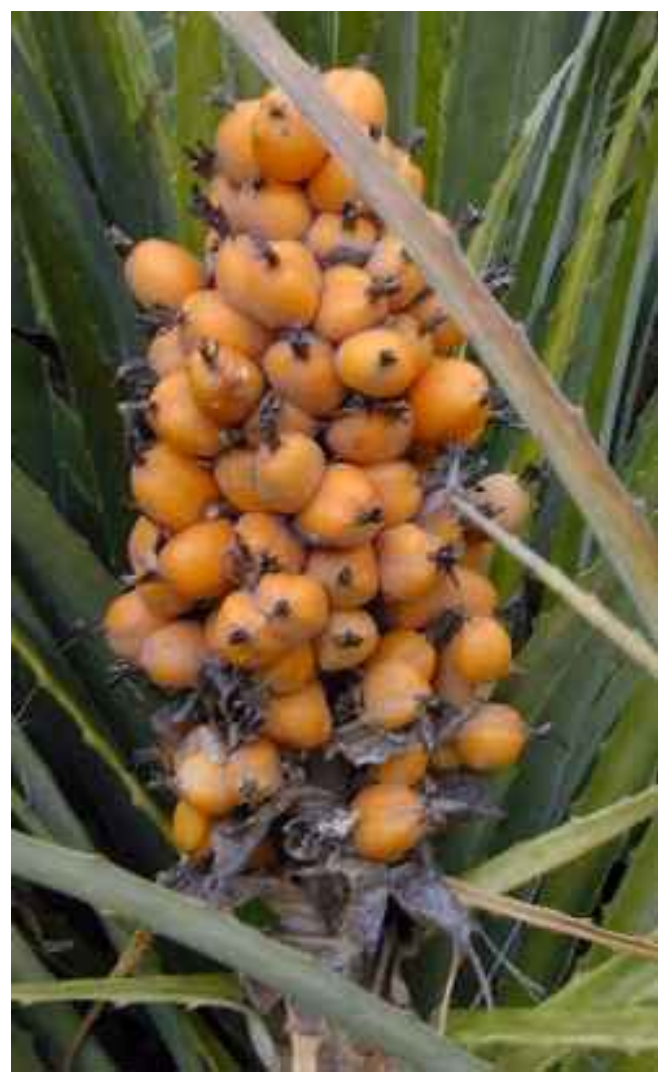

Figura 21: Bromelia balansae (caraguatá, bromeliácea medicinal do cerrado).

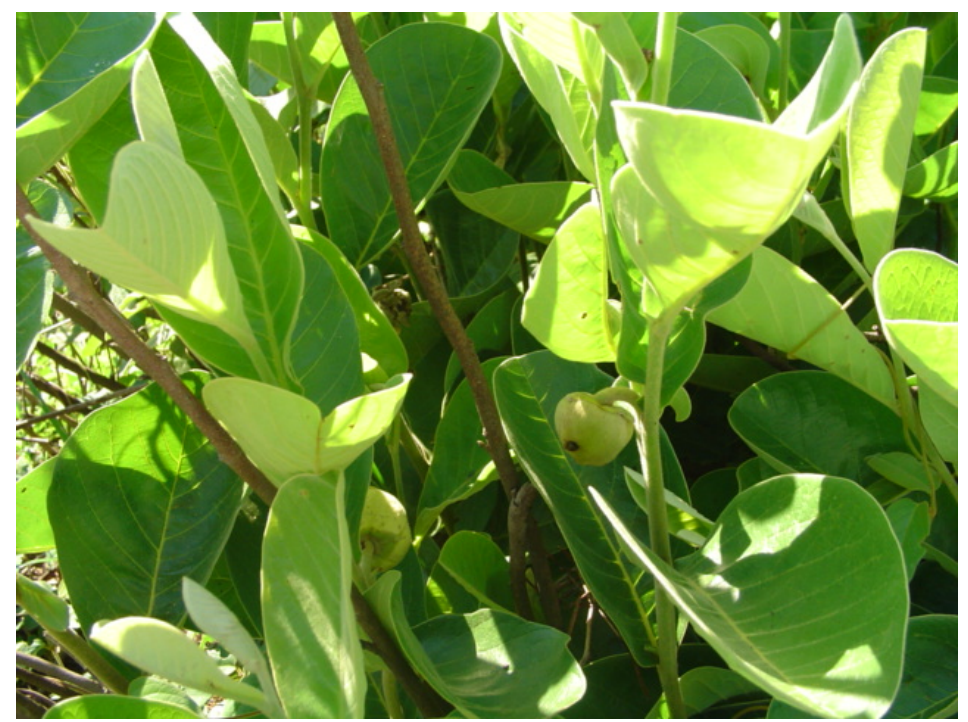

Figura 22: Anonna coriacea (fruto comestível). 

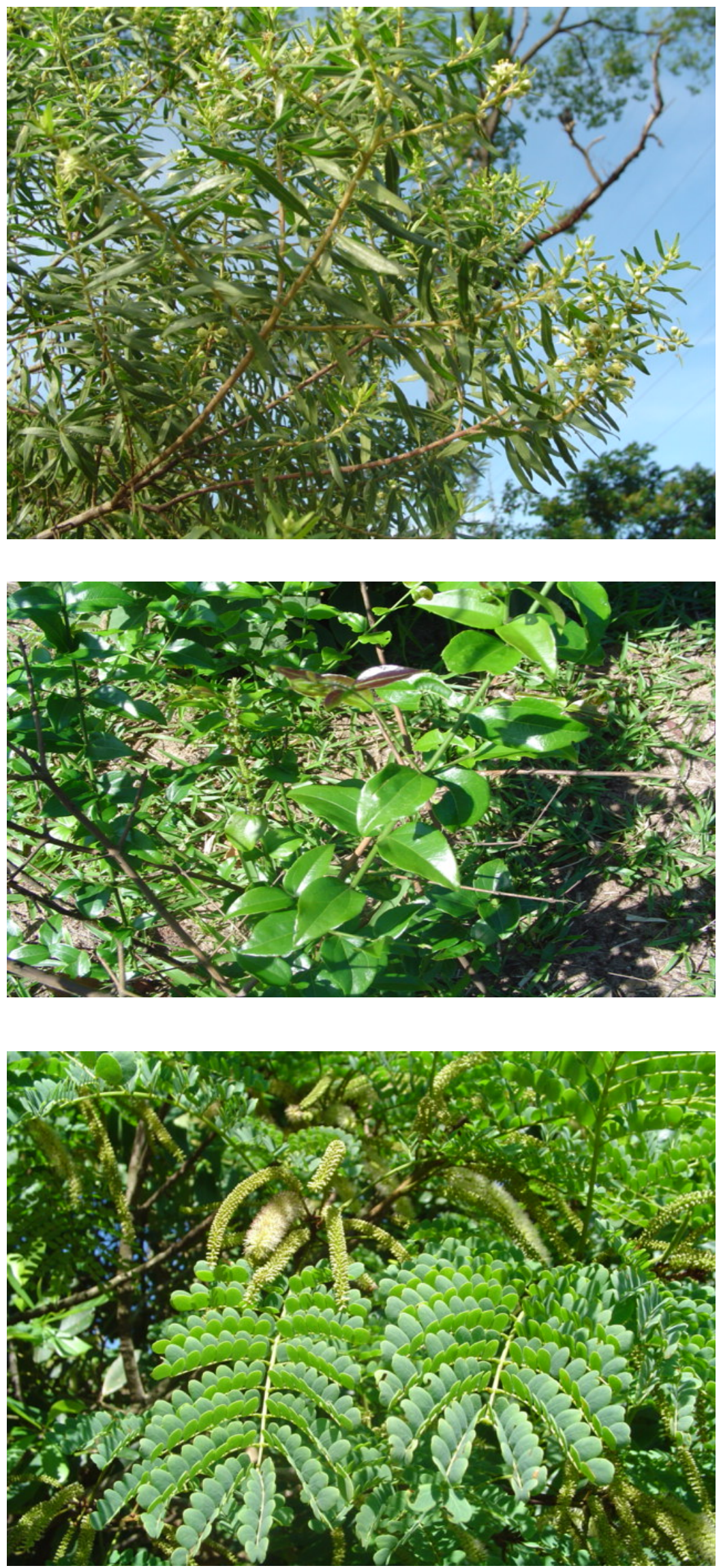

Figura 23: Plantas medicinais da área verde (a partir de cima, Baccharis dracunculifolia, Strychnos pseudo-quina e Stryphnodendron adstringens). 

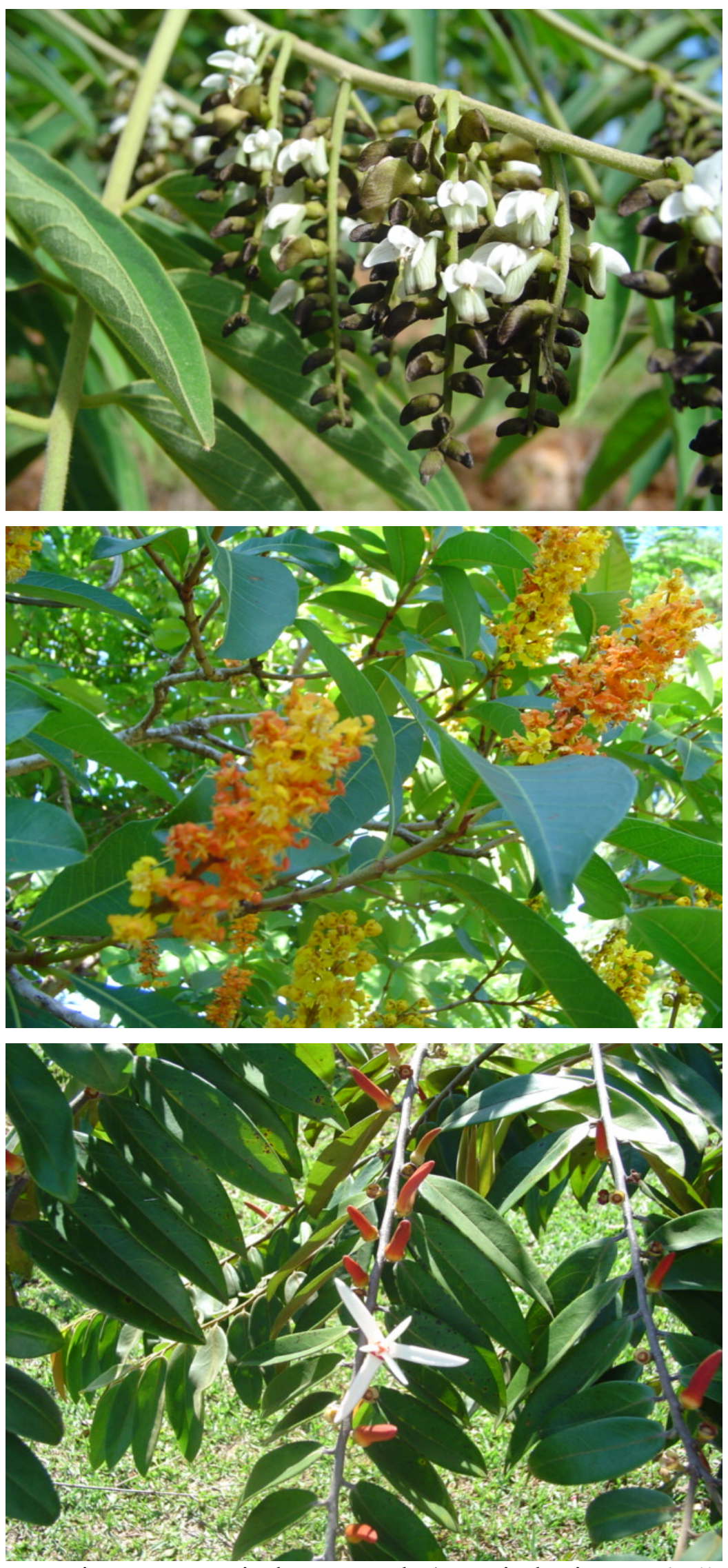

Figura 24: Espécies ornamentais da área verde (a partir de cima Cedrella fissilis, Vochysia tucanorum e Xylopia aromatica). 


\subsubsection{CÓRREGO DA ÁGUA QUENTE}

Os sistemas lóticos são sistemas complexos de drenagem e de transporte com intensa comunicação com os ecossistemas terrestres, de modo que suas características e a qualidade de suas águas são conseqüências das características naturais da bacia hidrográfica a que pertencem, associadas às atividades humanas desenvolvidas nessa bacia (SALAMI, 1996; PEDROSO et al., 1988).

O principal corpo d'água da MCAQ é o Córrego da Água Quente (CAQ), que pertence à Sub-bacia do Rio Jacaré-Guaçu (sub-bacia JG-2) e é tributário do Rio do Monjolinho (DAAE, 1974). Possui aproximadamente $6 \mathrm{~km}$ de extensão, da nascente inicial (próxima ao ponto N-Vale) até a foz no encontro com o Rio do Monjolinho.

De acordo com Bjornberg e Tolentino (1959), São Carlos é drenada por cursos d'água de dois tipos principais, do ponto de vista de suas nascentes: cursos com nascentes no planalto e cursos com nascentes fora do planalto. O Córrego da Água Quente nasce fora do planalto de São Carlos, próximo às escarpas do mesmo. Esse córrego nasce na região sudoeste da cidade, no arenito Botucatu, segue com margens abertas e pequeno declive, e o sentido geral de drenagem é de leste para oeste (SANTOS, 1993).

De acordo com o Departamento de Águas e Energia Elétrica do Estado de São Paulo (DAEE), o Córrego da Água Quente apresenta uma vazão estimada em cerca de $131 \mathrm{~L} / \mathrm{s}$ para a vazão média e cerca de $54 \mathrm{~L} / \mathrm{s}$ para a vazão mímima que se mantém por sete dias consecutivos, e drena solos ácidos (PEPINO et al., 2002; TEIA, 2002).

Bjornberg e Tolentino (op cit.) descreveram que o Córrego da Água Quente está localizado numa região de depósitos aluvionares (recentes), e junto a este observavamse pequenos vales entulhados totalmente com material trazido dos taludes da serra. Nas proximidades desse córrego, o arenito apresenta inclusões retangulares ou poligonais de argila, com 2 a $3 \mathrm{~cm}$ de lado. A análise granulométrica de material indicou a existência de cerca de 3,5\% de argila. $\mathrm{O}$ pH do solo desse perfil era em torno de 4,6.

De acordo com os mapas apresentados por Espíndola (2000), o CAQ possui dezoito regiões de nascentes, mas durante as pesquisas na área, encontramos apenas oito. Algumas das nascentes do Córrego da Água Quente localizam-se em fragmentos de vegetação natural e outras em locais com acentuada interferência antrópica, como no caso da nascente adjacente à avenida Pacaembu, onde ocorreu a retirada de parte da vegetação ciliar e a colocação de uma tubulação. 
Com relação ao uso e ocupação da área, Santos (1993) observou diversos pontos de extração mineral que se destinavam à construção civil. E também fez referência à presença de um único loteamento residencial entre o Córrego da Água Quente e o Córrego da Água Fria, o bairro Cidade Aracy, no ano de 1993. Nessa época, o Córrego da Água Quente já recebia esgoto in natura proveniente do bairro Cidade Aracy e de bairros adjacentes como o Jardim Cruzeiro do Sul. Atualmente, entre esses dois córregos existem os bairros Collor de Melo, Cidade Aracy e Loteamento Social Antenor Garcia, e os efluentes destes bairros ainda são despejados no Córrego da Água Quente.

Segundo o Decreto Estadual 10.755/77 o Córrego da Água Quente é enquadrado como Classe 2 (SÃO PAULO, 1977), e de acordo com a Resolução CONAMA 20, alterada pela Resolução 357, de 17/03/2005, esse enquadramento deve assegurar os seguintes usos: abastecimento para consumo humano (para usos domésticos em geral), após tratamento convencional; proteção das comunidades aquáticas; recreação de contato primário (como natação); irrigação de hortaliças, plantas frutíferas, parques, jardins, campos de esporte e lazer; aqüicultura e pesca. Porém, nenhum desses usos é possível considerando-se o atual estado de impactação do córrego.

Degradado, poluído, descaracterizado, o Córrego da Água Quente historicamente sempre sofreu um profundo descaso pelo poder público e por parte da população, e atualmente alguns dos maiores impactos do córrego ainda são os efluentes domiciliares presentes (conforme mostrado na figura 25) no seu leito, sem nenhum tratamento ou cuidado prévio, e a redução de vegetação natural em suas margens, que contribuem para processos erosivos e o assoreamento do córrego (figura 26).

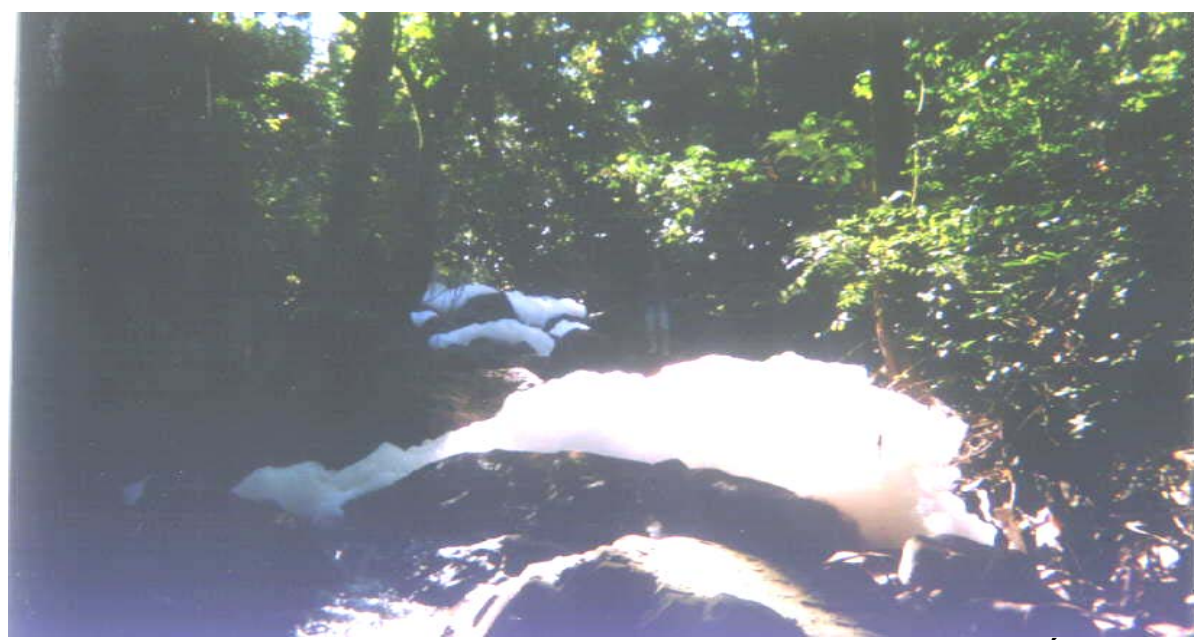

Figura 25: Interior da mata galeria (detalhe do Córrego da Água Quente com grande quantidade de espuma). 

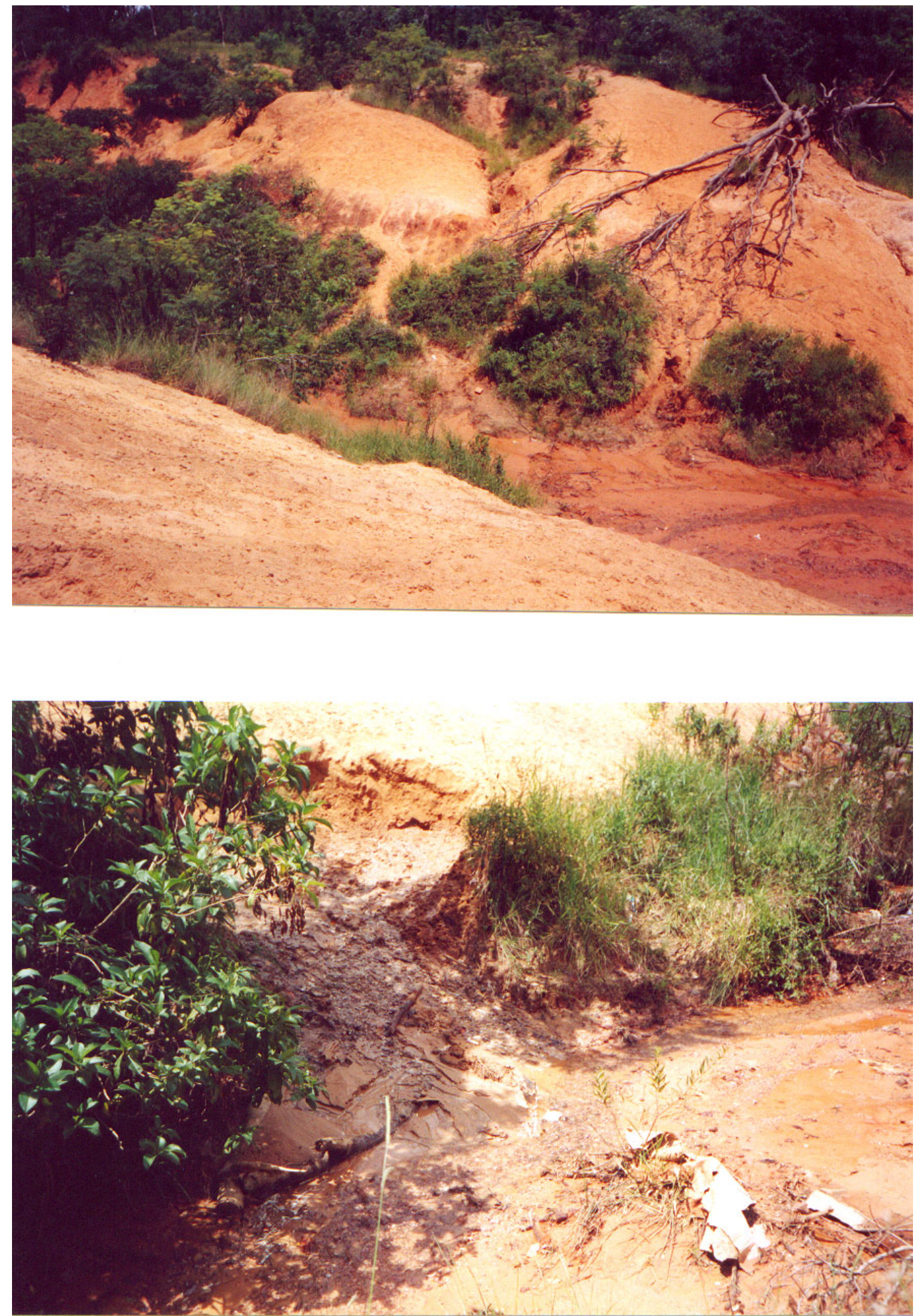

Figura 26: Área de nascentes assoreadas do Córrego da Água Quente (presença de voçorocas e resíduos sólidos).

Em relação aos efluentes domésticos despejados no CAQ, a atual gestão municipal, juntamente com o SAAE, tem planos de inaugurar uma Estação de Tratamento de Esgoto (ETE) ainda nessa gestão, o que sanará uma das principais fontes poluidoras da MCAQ. E, segundo projeto da atual prefeitura, o volumoso despejo de 
entulhos de construção às margens do CAQ no trecho próximo ao bairro Antenor Garcia será encerrado pelo encaminhamento deste material ao Aterro Municipal de Entulhos, já com local determinado.

Alguns estudos sobre as características limnológicas de sistemas lóticos foram realizados em bacias e microbacias da região de São Carlos, como os de Maier (1987) na Bacia do Rio Jacaré-Pepira; Sé (1992) no Rio do Monjolinho; Rios (1993), Rios e Calijuri (1995), Teixeira (1993) e Santos (1996) no Ribeirão do Feijão; Santos (1993) nos Córregos da Água Quente e da Água Fria, e Primavesi et al. (2000) no Ribeirão Canchim.

\subsubsection{VARIÁVEIS CLIMATOLÓGICAS}

As variações mensais de temperatura $\left({ }^{\circ} \mathrm{C}\right)$ e diárias de precipitação $(\mathrm{mm})$ foram fornecidas pela Estação Climatológica do Centro de Recursos Hídricos e Ecologia Aplicada / USP.

\section{Precipitação}

Os dados de precipitação da Microbacia do Córrego da Água Quente indicam a distinção entre um período de menores índices de pluviosidade, entre os meses de abril e agosto de $2002(0,3 \mathrm{~mm}$ a 25,0 $\mathrm{mm})$, caracterizando um período seco - sendo que o mês mais seco foi junho de 2002, não havendo ocorrência de chuva durante todo o mês. Os maiores índices de precipitação ocorreram de dezembro de 2001 a março de 2002 (máxima de 96,6mm), e de outubro a dezembro de 2002 (máxima de 79,0mm), caracterizando um período chuvoso. A precipitação nos dias de coleta pode ser observada no quadro 4.

\section{Temperatura do ar}

As temperaturas registradas no período seco variaram entre $0,8^{\circ} \mathrm{C}$ em julho de 2002 e $32,3^{\circ} \mathrm{C}$ em abril de 2002 . No período chuvoso, em dezembro de 2001 e outubro de 2002 registrou-se a mínima de $10,2^{\circ} \mathrm{C}$, e a temperatura máxima ocorreu em outubro 
de 2002 , com $37,4^{\circ} \mathrm{C}$. O quadro 4 mostra as temperaturas máximas e mínimas nos dias de coleta.

\begin{tabular}{|c|c|c|c|}
\hline \multirow{2}{*}{ DATA } & \multicolumn{2}{|c|}{ TEMPERATURA DO AR ( $\left.{ }^{\mathbf{0}} \mathbf{C}\right)$} & PRECIPITAÇÃO (mm) \\
\cline { 2 - 4 } & MÁXIMA & MÍNIMA & \\
\hline $03 / 12 / 01$ & 30,4 & 11,8 & 0 \\
\hline $14 / 01 / 02$ & 23,4 & 18,4 & 20 \\
\hline $14 / 02 / 02$ & 23,8 & 12,4 & 12,3 \\
\hline $14 / 03 / 02$ & 30,4 & 15,8 & 0 \\
\hline $17 / 04 / 02$ & 31,8 & 13,2 & 0 \\
\hline $29 / 05 / 02$ & 22 & 10,4 & 0 \\
\hline $19 / 06 / 02$ & 28,8 & 10,4 & 0 \\
\hline $10 / 07 / 02$ & 23,6 & 7,2 & 21,7 \\
\hline $07 / 08 / 02$ & 31,4 & 12,4 & 0 \\
\hline $06 / 09 / 02$ & 31,8 & 13,8 & 0 \\
\hline $09 / 10 / 02$ & 35,5 & 17,2 & 0 \\
\hline $08 / 11 / 02$ & 28,5 & 11,7 & 2,3 \\
\hline $11 / 12 / 02$ & 25,4 & 19,8 & \\
\hline
\end{tabular}

Quadro 4: Precipitação e temperatura (máximas e mínimas), nos dias de coleta, na Microbacia do Córrego da Água Quente, São Carlos, SP.

\subsubsection{CARACTERIZAÇÃO LIMNOLÓGICA DO CÓRREGO DA ÁGUA QUENTE}

\subsection{VARIÁVEIS FÍSICAS, QUÍMICAS E BIOLÓGICAS DA ÁGUA}

De acordo com Whitton (1975), a composição química dos sistemas lóticos é o resultado de diversos processos, como a decomposição das rochas, clima, características geológicas e vegetação. Contudo, uma considerável influência na composição das águas dos rios e córregos é provocada pelos usos múltiplos que os seres humanos fazem destes e também das atividades que ocorrem nas suas bacias de drenagem.

\section{Temperatura da água}

Neste trabalho as maiores temperaturas foram observadas em março e abril de 2001 para o ponto $\mathrm{AQ}$-Antenor, com máximas de $27,9^{\circ} \mathrm{C}$ e $25,9^{\circ} \mathrm{C}$, respectivamente, e em dezembro de 2001 (período chuvoso) para o ponto AQ-Aracy, chegando a $25,9{ }^{\circ} \mathrm{C}$. 
De acordo com os dados obtidos para temperatura (Figura 27), pôde-se observar que a variação em cada um dos pontos de coleta (exceto N-Pacaembu) ao longo do ano teve influência sazonal, sendo que os maiores valores obtidos aparecem nos meses de verão (período chuvoso) e os menores valores aparecem no inverno, principalmente em julho (período seco). O ponto N-Pacaembu não seguiu este padrão, apresentando valores entre $21,5^{\circ} \mathrm{C}$ e $23,8^{\circ} \mathrm{C}$ durante todas as coletas, com uma variação de apenas $2,3{ }^{\circ} \mathrm{C}$, enquanto nos demais pontos esta diferença variou entre $4,1{ }^{\circ} \mathrm{C}$ e $10,4{ }^{\circ} \mathrm{C}$. As maiores temperaturas da água no período chuvoso poderiam estar associadas à entrada de material particulado, uma vez que as partículas de sólidos presentes na água representam uma fonte de acumulação de calor, bem como à própria insolação elevada desta época. Os dados completos encontram-se no anexo 8.

As variações de temperatura entre os pontos, possivelmente deveram-se a dois fatores principais. Em primeiro lugar, ao horário das coletas, uma vez que a temperatura foi medida sempre pela manhã, entre 8:00 e 10:00 horas, após período escuro (sem aquecimento solar). Como a temperatura da água tende a manter-se mais constante que a temperatura do ar, as variações encontradas entre os diferentes pontos em um mesmo mês foram pequenas. Ocorreu uma exceção no mês de julho de 2002, nos pontos AQBelvedere e AQ-Gonzaga, em que a temperatura diminuiu bastante, atingindo valores de $14,3{ }^{\circ} \mathrm{C}$ e $14,7^{\circ} \mathrm{C}$, respectivamente, em conseqüência da mudança de temperatura do ar. A temperatura da água varia espacial e temporalmente e está diretamente relacionada com a temperatura do ar adjacente. A variação temporal é diurna e sazonal, ocorrendo geralmente as maiores temperaturas à tarde e as menores no final da noite (HYNES, 1970).

Em segundo lugar, as variações de temperatura entre os pontos estão relacionadas ao grau de insolação do ponto de coleta, pois pudemos observar que pontos como o AQ-Belvedere, situado em local sombreado em todas as horas do dia, ao longo de todo o ano, apresentou os menores valores de temperatura, entre $14,3{ }^{\circ} \mathrm{C}$ e $24,7{ }^{\circ} \mathrm{C}$, enquanto pontos com insolação direta ao longo de todo o ano, apresentaram as maiores temperaturas durante todo o período de coletas, como o AQ-Aracy, cuja temperatura variou entre $18,7^{\circ} \mathrm{C}$ e $25,9^{\circ} \mathrm{C}$ e o AQ-Antenor, com valores entre $19,2^{\circ} \mathrm{C}$ e $27,9^{\circ} \mathrm{C}$. A insolação exerceu importante influência na variação da temperatura da água também devido à pequena profundidade, sempre menor que $1,0 \mathrm{~m}$, em todos os pontos de coleta, o que facilita o aquecimento da água pelos raios solares. Essa pequena profundidade é conseqüência do assoreamento provocado pela ausência de mata ciliar. Segundo Santos 
(1993), o Córrego da Água Quente (CAQ) apresenta pequena profundidade em toda a sua extensão, com menos de 1 metro de profundidade, e na estação seca, forma apenas uma lâmina d'água em quase todo o seu curso, devido ao assoreamento.

Geralmente as temperaturas encontradas são mais baixas nas nascentes, ou em locais sombreados por mata ciliar. De acordo com Matheus e Tundisi (1988), onde não há mata ciliar, é comum encontrar-se temperaturas mais elevadas, devido à radiação solar direta, como é o caso do CAQ, cujas margens foram quase completamente desmatadas. Maier (1983), estudando a Bacia do Rio Jacaré-Pepira observou variações espaciais e temporais de temperatura da água, sendo que os menores valores foram encontrados nos trechos próximos a nascentes e com mata ciliar. Rios (1993) também registrou menores temperaturas em áreas de nascente do Ribeirão do Feijão.

A temperatura da água observada no ponto $\mathrm{N}-$ Vale, com máxima de $23,4{ }^{\circ} \mathrm{C}$ em outubro de 2002 e mínima de $18,9{ }^{\circ} \mathrm{C}$ em julho, que manteve-se menor se comparada, por exemplo, ao AQ-Antenor, que atingiu $27,9^{\circ} \mathrm{C}$ em março de 2002 , e a presença da peixes do gênero Poecilla sp., podem ser explicadas pela presença de mata ciliar (ainda que bastante impactada em alguns trechos) nessa área de nascentes, logo à montante do ponto de coleta. Este é um aspecto relevante para a sensibilização da comunidade local em relação à importância da recuperação e conservação da mata ciliar em toda a microbacia. 


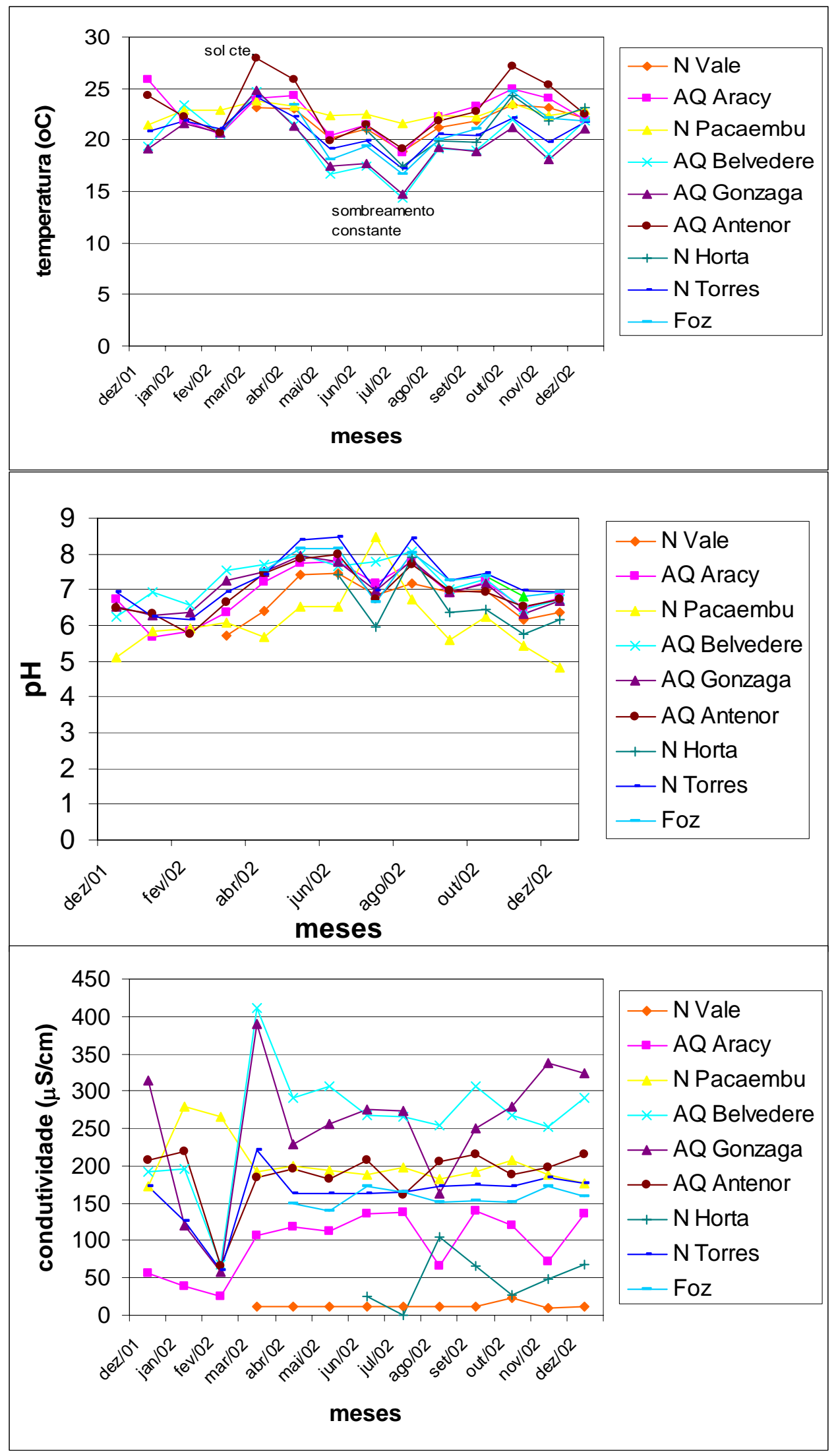

Figura 27: Variações espacial e temporal da temperatura $\left({ }^{\circ} \mathrm{C}\right), \mathrm{pH}$ e condutividade $(\mu \mathrm{s} / \mathrm{cm})$ em nove pontos da Microbacia do Córrego da Água Quente (São Carlos-SP) entre dezembro de 2001 e dezembro de 2002. 
pH

As variações encontradas para os valores de $\mathrm{pH}$ na Microbacia do Córrego da Água Quente encontram-se no anexo 9, e na Figura 27.

Nos meses mais frios, de maio a agosto de 2002 (período seco), foi possível observar, em todos os pontos, os maiores valores de $\mathrm{pH}$, que estiveram entre 6,5 e 8,5. Nos períodos de maior precipitação, ocorreram no ponto N-Pacaembu, os menores valores encontrados durante todo o período de coletas, sendo 5,1 em dezembro de 2001 e 4,8 em dezembro de 2002, no período de meses quentes e chuvosos. Conforme Maier (1983), os rios brasileiros apresentam valores de $\mathrm{pH}$ entre neutro e ácido. Como o Córrego da Água Quente drena solos ácidos (LORANDI, 1985), esse padrão de variação sazonal pode estar relacionado à maior entrada de material particulado por carreamento desse tipo de solo, à decomposição de matéria orgânica proveniente do ambiental natural e da descarga de esgoto doméstico, que geram substâncias húmicas diminuindo o pH. Santos (1993) observou em quatro pontos do AQ que na estação seca o pH variou entre 5,8 e 6,7, e na estação chuvosa, esteve entre 6,5 e 7,1.

Pode-se observar que ao longo do período de coletas houve uma variação de $\mathrm{pH}$ relativamente alta entre as diversas estações e ao longo do tempo na mesma estação. Os valores variaram entre 4,8 e 8,5. Quanto à variação temporal dos pontos, o que mais se destaca é a N-Pacaembu, cujo pH variou entre 8,5 (em julho de 200) e 4,8 (em dezembro de 2002).

Conforme foi observado nas nascentes N-Vale e N-Pacaembu, baixos valores de pH também podem estar associados, segundo Reid e Wood (1976) à presença de mata ciliar ou a regiões pantanosas, onde há maior presença de matéria orgânica em decomposição, que aumenta a liberação de $\mathrm{CO}_{2}$ e a formação de ácidos húmicos, que contribuem para a diminuição do $\mathrm{pH}$.

\section{Condutividade}

No que se refere à condutividade, o ponto que manteve os menores valores, relativamente constantes, durante o período de coletas foi a N-Vale, com variações entre $10 \mu \mathrm{S} / \mathrm{cm}$ e $12 \mu \mathrm{S} / \mathrm{cm}$, exceto em outubro de 2002 quando chegou a $24 \mu \mathrm{S} / \mathrm{cm}$.

Comparando-se a condutividade dos demais pontos de coleta, os menores valores foram encontrados no ponto N-Horta, entre $0,21 \mu \mathrm{S} / \mathrm{cm}$ em julho e $105 \mu \mathrm{S} / \mathrm{cm}$ 
em agosto de 2002. Essa elevação brusca no mês de agosto pode ser devida à precipitação no dia da coleta. Os valores mais elevados foram encontrados nos pontos AQ-Belvedere e AQ-Gonzaga, sendo $412 \mu \mathrm{S} / \mathrm{cm}$ e $390 \mu \mathrm{S} / \mathrm{cm}$, respectivamente.

A alta condutividade dos pontos AQ-Belvedere e AQ-Gonzaga reflete a influência dos impactos existentes nas margens, como a presença e o pisoteamento por cavalos e bois, o assoreamento e a emissão de poluentes (efluentes domésticos e resíduos sólidos) que elevam a concentração de íons, aumentando a condutividade.

Em quatro pontos do Córrego da Água Quente, Santos (1993) observou valores bastante variados para a condutividade, entre $12 \mu \mathrm{S} / \mathrm{cm}$ (nascente) e $129 \mu \mathrm{S} / \mathrm{cm}$ na estação seca, e $13 \mu \mathrm{S} / \mathrm{cm}$ (nascente) e $112 \mu \mathrm{S} / \mathrm{cm}$ na estação chuvosa. Neste trabalho, não foi observado nenhum padrão de variação temporal dos valores de condutividade entre dezembro de 2001 e dezembro de 2002, conforme evidencia a figura 27 , e todos os valores podem ser vistos no Anexo 10.

Os dados de condutividade obtidos nos diversos pontos de coleta demonstram um sistema heterogêneo para cada mês de coleta, em todo o período amostrado. Esta variação pode ser conseqüência da entrada inconstante de matéria orgânica proveniente de esgoto doméstico e da lixiviação do solo.

\section{Oxigênio Dissolvido (OD)}

Todos os valores de oxigênio dissolvido estão representados no Anexo 10, e as variações espaciais e temporais podem ser observadas na figura 28.

Constatou-se nesta pesquisa que os valores de OD mais uniformes e elevados ao longo das coletas ocorreram nas nascentes N-Vale e N-Torres, sendo que na N-Vale variaram entre 9,8 mg/L em junho de 2002 e 7,2 mg/L em outubro de 2002, e na NTorres, mantiveram-se entre 7,2 mg/L em janeiro de 2002 e 8,9 mg/L em junho de 2002. Portanto, o maior valor foi obtido no mês de junho (período seco) para ambas as nascentes.

No outro extremo, as menores concentrações de OD foram observadas nos pontos N-Horta, AQ-Belvedere e AQ-Gonzaga. No ponto N-Horta, onde realizamos coletas de junho a dezembro de 2002, foram encontrados os menores valores de oxigênio (abaixo de 2,4 mg/L de agosto a dezembro, e abaixo de 1,0 mg/L em setembro, novembro e dezembro de 2002). Há que se considerar que, diferentemente dos demais 
pontos, a N-Horta é um "poço" e não apresenta corredeira. No ponto AQ-Belvedere o OD manteve-se abaixo de 3,4 mg/L nos meses de dezembro de 2001 e março, abril, maio, junho, julho, outubro e dezembro de 2002. E atingiu um pico de 9,0 mg/L em setembro de 2002, possivelmente devido ao aumento da corredeira. No AQ-Gonzaga, o OD manteve-se abaixo de 2,1 mg/L nos meses de dezembro de 2001 e março, abril, maio, junho, setembro, outubro, novembro e dezembro de 2002.

Essas baixas concentrações devem-se à presença de grande quantidade de matéria orgânica em decomposição, uma vez que os pontos AQ-Belvedere e AQGonzaga recebem grande concentração de efluentes domésticos e que o ponto N-Horta recebe esterco de animais carreado pelas chuvas. Constatou-se também a presença de nitrito nos pontos de coleta, o qual é um composto nitrogenado muito instável e utiliza o oxigênio dissolvido para atingir a forma mais estável e assimilável pelas plantas, que é o nitrato.

No que se refere ao oxigênio, constatou-se no presente trabalho que os corpos d'água da Microbacia do Córrego da Água Quente (córrego e nascentes) possuem grandes variações que se devem a várias razões: a variação da quantidade de água que ocorre entre os períodos seco e chuvoso, e a variação da quantidade de efluentes domésticos que chegam até os corpos d'água da microbacia, aumentam ou diminuem a velocidade de descida da água, influenciando diretamente na concentração de oxigênio dissolvido.

Santos (1993) observou que as concentrações de OD no Córrego da Água Quente variaram entre $5,5 \mathrm{mg} / \mathrm{L}$ e $8,3 \mathrm{mg} / \mathrm{L}$ no período seco e $5,4 \mathrm{mg} / \mathrm{L}$ e $8,3 \mathrm{mg} / \mathrm{L}$ no período chuvoso. Também observou que a nascente apresentou maior concentração em relação aos outros três pontos por ela estudados. No presente trabalho, não foi possível observar uma influência sazonal na variação das concentrações de OD.

Segundo Branco (1986) e Matheus e Tundisi (1988), a introdução de efluentes domésticos nos rios contribui fortemente para a redução do oxigênio dissolvido, devido à ação das bactérias para a decomposição da matéria orgânica. Todavia, em sistemas lóticos a concentração de OD geralmente é mais alta nos trechos com mais corredeiras dependendo, portanto, das características geomorfológicas do local. Além disso, a concentração de OD também pode sofrer influência da temperatura, uma vez que em dias mais quentes ocorre menor solubilidade desse gás na água e aumenta a atividade biológica, provocando maior consumo de OD. 
Apesar de haver presença de esgoto doméstico em grande concentração em todos os pontos de coleta, com exceção das nascentes, foram verificadas concentrações de oxigênio extremamente baixas apenas nos pontos N-Horta, AQ-Gonzaga e AQBelvedere. Sabendo-se que ocorre corredeira em diferentes graus em todos os pontos, essa pode ser a principal razão para a presença de oxigênio dissolvido nos demais pontos. Este processo de auto-depuração pode estar favorecendo a oxigenação da massa de água contribuindo para a solubilização de oxigênio pelo corpo d'água.

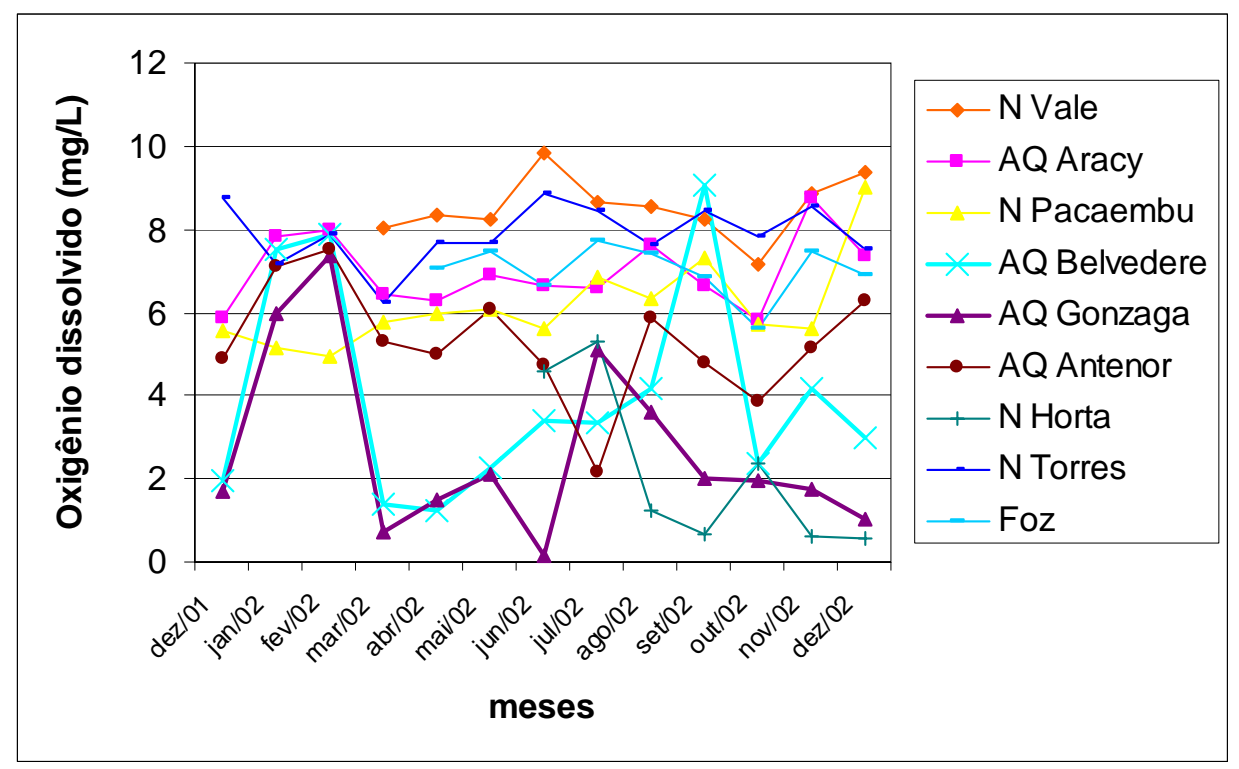

Figura 28: Variações espacial e temporal de oxigênio dissolvido (mg/L) em nove pontos da Microbacia do Córrego da Água Quente (São Carlos-SP) entre dezembro de 2001 e dezembro de 2002.

\section{Nutrientes}

\section{FORMAS NITROGENADAS}

\section{Nitrogênio orgânico total, nitrito, nitrato e amônio}

Conforme explica Hynes (1970), as principais fontes de nitrogênio para o sistema são o nitrato e a amônia provenientes da chuva, a fixação e a desnitrificação biológica, o fogo e a erosão naturais, e a reciclagem de nitrogênio pela vegetação ou contido na camada húmica.

As figura 29 e 30, e os anexos 11 e 12 apresentam as variações espacial (ponto a ponto) e temporal (mês a mês) das formas nitrogenadas na microbacia. 
As maiores concentrações de nitrogênio orgânico total da Microbacia do Córrego da Água Quente foram obtidas no período seco para os pontos localizados no córrego, variando de 12,4 mg/L na Foz em maio de 2002 a 56,2 mg/L no AQ-Gonzaga em junho de 2002. No período chuvoso, as concentrações ao longo do córrego estiveram entre 6,4 mg/L em fevereiro de 2002 e 42,0 mg/L em dezembro de 2002. Os pontos AQ-Gonzaga, AQ-Belvedere e AQ-Antenor destacaram-se por apresentar as maiores concentrações de nitrogênio, sendo que os valores máximos foram $56,2 \mathrm{mg} / \mathrm{L}$ no AQ-Gonzaga (junho de 2002), 46,0 mg/L no AQ-Belvedere (julho de 2002) e 31,0 mg/L no AQ-Antenor (agosto de 2002).

Em relação às nascentes, ao longo dos meses de coleta, observou-se um padrão em relação à presença de nitrogênio que se traduz num baixo gradiente de concentração nas quatro nascentes estudadas. A N-Pacaembu foi o ponto onde ocorreu a menor variação temporal da concentração de nitrogênio, havendo uma variação entre zero $\mathrm{mg} / \mathrm{L}$ (março de 2002) e 1,4 mg/L (junho de 2002). Nas demais nascentes, as concentrações de nitrogênio mantiveram-se sempre abaixo de 3,9 mg/L, com exceção de um pico de 9,8 mg/L na N-Horta em agosto de 2002 e de 11,9 mg/L na N-Torres em março de 2002.

Outra padrão evidenciado nas nascentes N-Vale e N-Pacaembu foi com relação ao nitrito que apresentou concentrações relativamente baixas, que variaram entre 0,7 $\mu \mathrm{g} / \mathrm{L}$ na N-Pacamebu em julho de 2002 e 5,2 $\mu \mathrm{g} / \mathrm{L}$ na $\mathrm{N}-$ Vale em abril de 2002. Conforme visto na figura 29, um pico extremamente elevado de nitrito foi registrado no mês de março de 2002 para o ponto N-Torres $(460,7 \mu \mathrm{g} / \mathrm{L})$, além de alguns outros valores relativamente elevados neste mesmo ponto $(32,2 \mu \mathrm{g} / \mathrm{L}$ e $29,9 \mu \mathrm{g} / \mathrm{L})$ em janeiro e fevereiro de 2002, e na N-Horta $(36,4 \mu \mathrm{g} / \mathrm{L})$ em setembro de 2002.

Em relação aos pontos no córrego, as maiores concentrações de nitrito obtidas foram 127,5 $\mu \mathrm{g} / \mathrm{L}$ no AQ-Antenor (setembro de 2002), 88,6 $\mu \mathrm{g} / \mathrm{L}$ na Foz (novembro de 2002), 40,0 $\mu \mathrm{g} / \mathrm{L}$ no AQ-Belvedere e $28,8 \mu \mathrm{g} / \mathrm{L}$ no AQ-Gonzaga, as duas últimas em fevereiro de 2002.

Nos pontos que apresentaram concentrações mais elevadas de nitrito provavelmente ocorreu uma taxa maior de conversão de amônia em nitrito após a decomposição de matéria orgânica proveniente de esgoto, pois estes pontos recebem alta carga de efluentes domésticos. Concentrações elevadas de nitrito podem indicar condições anaeróbias, devido à presença de efluentes (CHAPMAN, 1992). Portanto, o nitrito aparece aqui como um indicador de poluição hídrica por efluentes domésticos 
nos pontos de maior concentração. A Resolução CONAMA 357/05 estabelece como valor limite nestes casos, $1 \mathrm{mg} / \mathrm{L}$.

Em relação ao nitrito no Córrego da Água Quente, Santos (1993) encontrou valores de $0,85 \mu \mathrm{g} / \mathrm{L}$ na nascente e entre $7,8 \mu \mathrm{g} / \mathrm{L}$ e $34,95 \mu \mathrm{g} / \mathrm{L}$ no córrego, na estação seca, e na estação chuvosa encontrou valores de $1,10 \mu \mathrm{g} / \mathrm{L}$ na nascente, e entre 10,09 $\mu \mathrm{g} / \mathrm{L}$ e $61,08 \mu \mathrm{g} / \mathrm{L}$ no córrego.

Com exceção da N-Horta, nesse estudo pudemos observar concentrações de nitrato bastante elevadas nas três outras nascentes, variando entre $10.427,0 \mu \mathrm{g} / \mathrm{L}$ na $\mathrm{N}$ Pacaembu em setembro de 2002 e $136 \mu \mathrm{g} / \mathrm{L}$ na N-Vale, em junho de 2002. É importante destacar que durante todo o período de coletas, as concentrações de nitrato na $\mathrm{N}$ Pacaembu estiveram acima de $1000 \mu \mathrm{g} / \mathrm{L}$ (exceto em agosto de 2002, em que foi de $943,8 \mu \mathrm{g} / \mathrm{L}$ ), sendo o ponto que apresentou as maiores concentrações de nitrato ao longo de todo o período de coletas.

Os menores valores de nitrato foram obtidos nos pontos a seguir, em que estão destacadas para cada um as concentrações mínimas e máximas: AQ-Gonzaga (17,6 $\mu \mathrm{g} / \mathrm{L}$ em dezembro de 2002 e 183,2 $\mu \mathrm{g} / \mathrm{L}$ em janeiro de 2002), AQ-Belvedere (13,3 $\mu \mathrm{g} / \mathrm{L}$ em junho de 2002 e $347,3 \mu \mathrm{g} / \mathrm{L}$ em janeiro de 2002) e N-Horta $(23,6 \mu \mathrm{g} / \mathrm{L}$ em novembro de 2002 e 58,4 $\mu \mathrm{g} / \mathrm{L}$ em setembro de 2002). O nitrato é a forma nitrogenada mais utilizada pelas plantas e a que mais ocorre em sistemas de água corrente (RIOS, 1993). Os valores de nitrato são elevados para a maioria dos pontos amostrados. A conversão de nitrito em nitrato pode estar ocorrendo, uma vez que para todo o período de coleta observam-se altas concentrações, quando comparadas com o nitrito.

A resolução CONAMA 20, alterada pela resolução 357/05 declara que os níveis aceitáveis para nitrito em corpos de água de classe 2 não deve exceder $10 \mathrm{mg} / \mathrm{L}$ N. Isto ocorreu, pelos dados obtidos, no ponto N-Pacaembu. Os valores obtidos de oxigênio poderiam favorecer essa conversão, mesmo nos pontos onde este está com baixas concentrações, já que não ocorre anoxia. Já no caso do ponto AQ-Gonzaga, em março e junho de 2002, observaram-se valores próximos à anoxia $(0,7 \mathrm{mg} / \mathrm{L}$ e $0,2 \mathrm{mg} / \mathrm{L}$, respectivamente) e as concentrações de nitrito foram maiores que as de nitrato. 


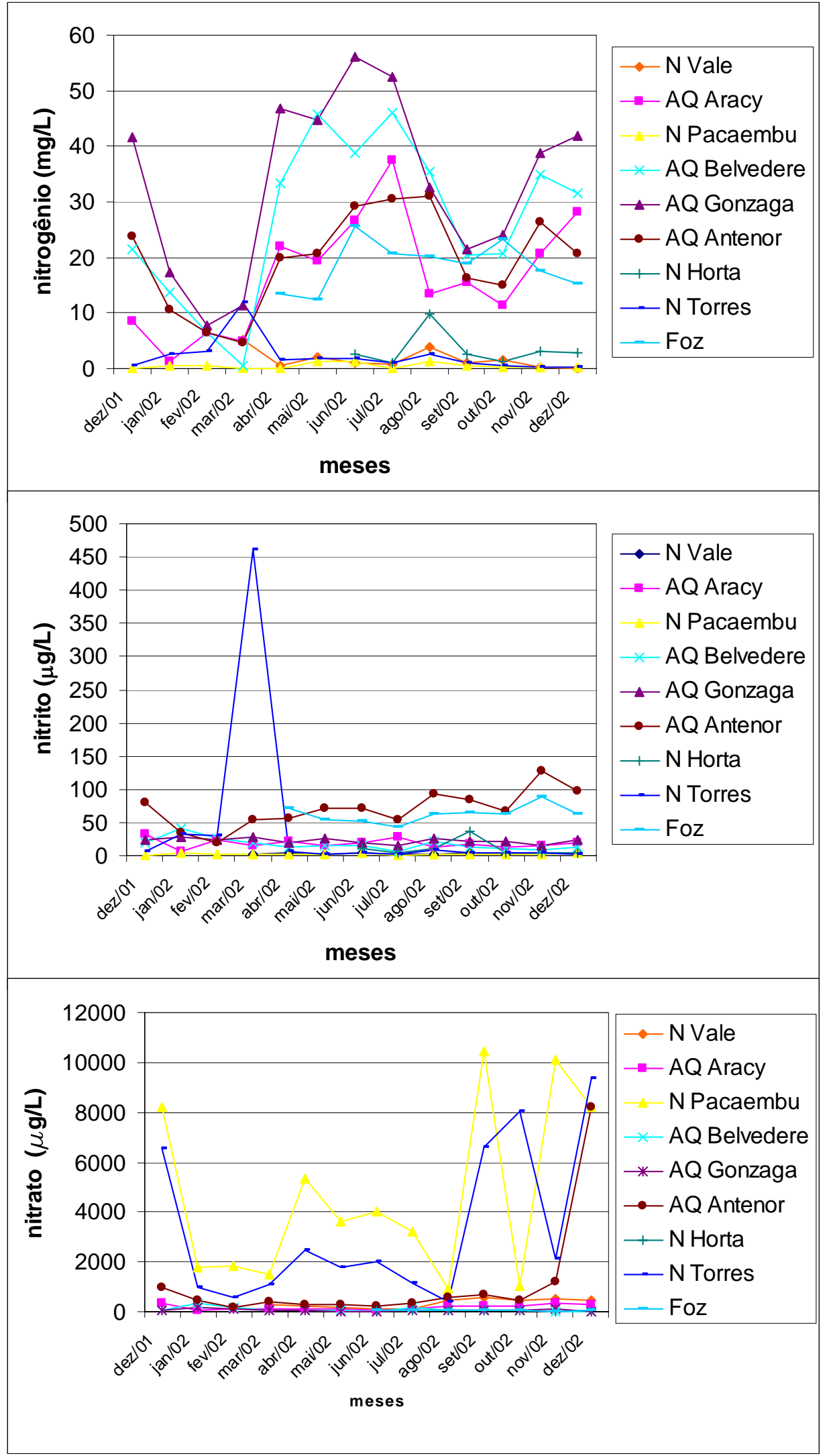

Figura 29: Variações espacial e temporal de nitrogênio orgânico total $(\mathrm{mg} / \mathrm{L})$, nitrito $(\mu \mathrm{g} / \mathrm{L})$ e nitrato $(\mu \mathrm{g} / \mathrm{L})$ em nove pontos da Microbacia do Córrego da Água Quente (São Carlos-SP) entre dezembro de 2001 e dezembro de 2002. 


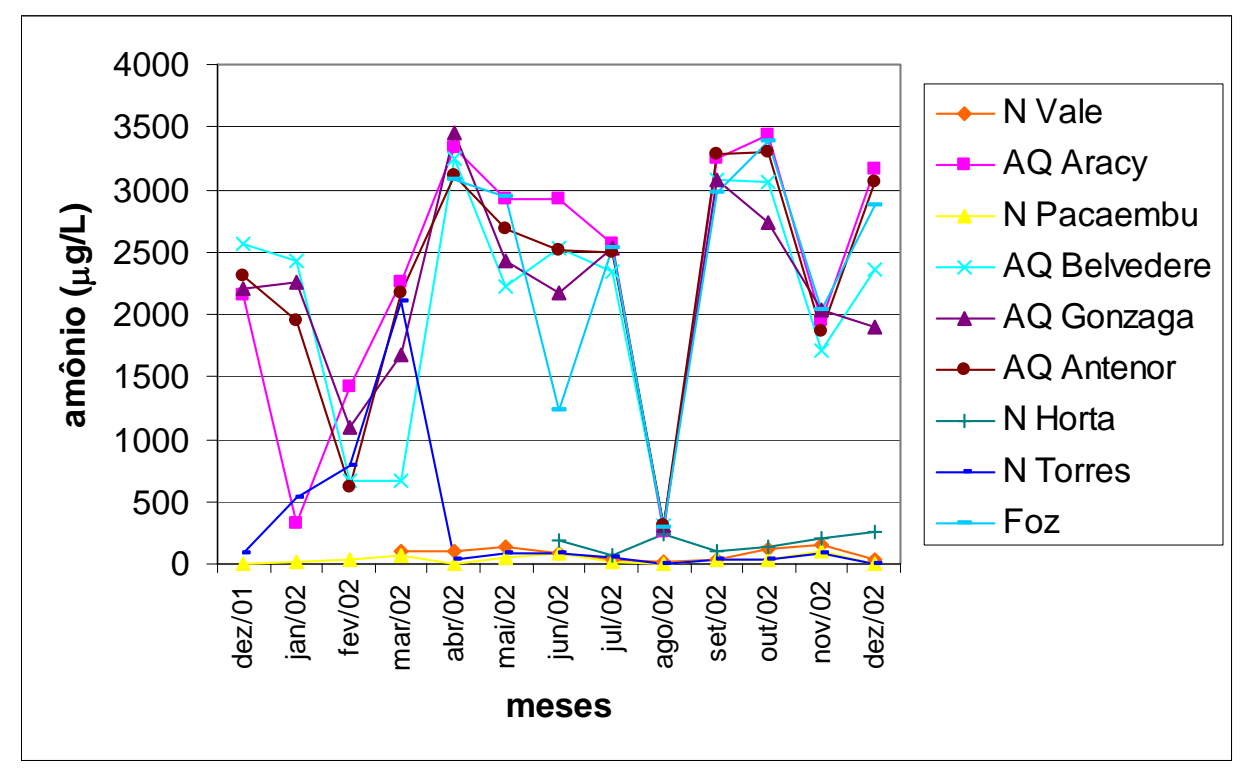

Figura 30: Variações espacial e temporal de e amônio $(\mu \mathrm{g} / \mathrm{L})$ em nove pontos da Microbacia do Córrego da Água Quente (São Carlos-SP) entre dezembro de 2001 e dezembro de 2002.

O íon amônio é originado a partir da amônia durante processos de decomposição, em pH próximo da neutralidade. Ambientes com baixa concentração de oxigênio dissolvido e elevada entrada de matéria orgânica favorecem essa transformação. Nesse estudo os maiores valores de amônio durante todo o período de coletas foram obtidos nos cinco pontos do córrego, com as seguintes concentrações máximas para cada ponto: $3435,7 \mu \mathrm{g} / \mathrm{L}$ no AQ-Aracy, 3251,4 $\mu \mathrm{g} / \mathrm{L}$ no AQ-Belvedere, $3445 \mu \mathrm{g} / \mathrm{L}$ no AQ-Gonzaga e $3385 \mu \mathrm{g} / \mathrm{L}$ na Foz).

Quando a concentração de oxigênio dissolvido é mais elevada favorece o processo de nitrificação, no qual o amônio é convertido em nitrato por organismos autotróficos, bactérias e fungos. Portanto, elevadas concentrações de nitrato podem indicar a presença de grandes quantidades de compostos orgânicos, indicando poluição orgânica (CHAPMAN, 1992; WETZEL, 1993). Esta pode ser a interpretação do que ocorreu na nascente N-Torres, que entre janeiro e março de 2002, recebeu esgoto doméstico devido a defeito em uma tubulação. Nesse ponto, foram obtidos valores relativamente elevados de oxigênio dissolvido, baixas concentrações de amônio, e concentrações elevadas de nitrato nos meses de janeiro, fevereiro e março de 2002 (537,2 $\mu \mathrm{g} / \mathrm{L}, 793,6 \mu \mathrm{g} / \mathrm{L}$ e 2099,1 $\mu \mathrm{g} / \mathrm{L}$, respectivamente).

De acordo com Chapman (1992), em ambientes naturais são encontrados valores de nitrato entre $100 \mu \mathrm{g} / \mathrm{L}$ e $1000 \mu \mathrm{g} / \mathrm{L}$, sendo que concentrações maiores que $100 \mu \mathrm{g} / \mathrm{L}$ 
podem indicar alto grau de poluição por despejos industriais e municipais, aterros, lixões ou fertilizantes. Todavia, o nitrato presente na N-Vale, que aparentemente não recebe efluentes domésticos pode ser proveniente principalmente da decomposição da matéria orgânica proveniente da mata ciliar e das fezes de gado e outros animais presentes no local (conversão de amônia em nitrito e deste em nitrato, graças à quantidade elevada de oxigênio disponível no sistema).

Santos (1993) encontrou valores de nitrato para o Córrego da Água Quente em 1990 que, durante a estação seca, foram 22,7 $\mu \mathrm{g} / \mathrm{L}$ na nascente e entre $122,04 \mu \mathrm{g} / \mathrm{L}$ e $864,97 \mu \mathrm{g} / \mathrm{L}$ no córrego, e na estação chuvosa, foram $31,20 \mu \mathrm{g} / \mathrm{L}$ na nascente e entre $63,96 \mu \mathrm{g} / \mathrm{L}$ e $487,7 \mu \mathrm{g} / \mathrm{L}$ no córrego.

\section{FORMAS FOSFATADAS}

\section{Fósforo total, fosfato inorgânico e fosfato total dissolvido}

Todos os valores obtidos para as formas fosfatadas e sua distribuição espacial e temporal podem ser observados nos Anexos 13 e 14 e na Figura 31). Para todas as formas fosfatadas, observaram-se as maiores concentrações durante todo o período de coletas, nos pontos AQ-Belvedere e AQ-Gonzaga.

O AQ-Belvedere apresentou valores de fósforo total acima de $1000 \mu \mathrm{g} / \mathrm{L}$, durante as coletas, com concentração máxima de 5141,3 $\mu \mathrm{g} / \mathrm{L}$, à exceção do mês de fevereiro de 2002, em que havia 432,1 $\mu \mathrm{g} / \mathrm{L}$. No AQ-Gonzaga, as concentrações de fósforo total também mantiveram-se acima de $1000 \mu \mathrm{g} / \mathrm{L}$, variando entre $1206,0 \mu \mathrm{g} / \mathrm{L}$ em janeiro de 2002 e 4626,0 $\mu \mathrm{g} / \mathrm{L}$ em fevereiro de 2002. De acordo com Chapman (1992) elevadas concentrações de fósforo total podem decorrer da descarga de efluentes municipais, compostos por esgoto e detergentes.

Em relação ao fosfato inorgânico, no AQ-Belvedere variou entre 196,6 $\mu \mathrm{g} / \mathrm{L}$ (fevereiro de 2002) e 2331,1 $\mu \mathrm{g} / \mathrm{L}$ (março de 2002), e no AQ-Gonzaga variou entre 198,5 $\mu \mathrm{g} / \mathrm{L}$ (fevereiro de 2002) e 2516,6 $\mu \mathrm{g} / \mathrm{L}$ (março de 2002. Os valores de fósforo total dissolvido no AQ-Belvedere variaram entre 263,7 $\mu \mathrm{g} / \mathrm{L}$ (fevereiro de 2002) e 2911 $\mu \mathrm{g} / \mathrm{L}$ (setembro de 2002), e no AQ-Gonzaga variaram entre 232,2 $\mu \mathrm{g} / \mathrm{L}$ (fevereiro de 2002) e $2719,8 \mu \mathrm{g} / \mathrm{L}$ (outubro de 2002). Chapman (1992) relata que as concentrações de fosfato total dissolvido em ambientes naturais variam entre $5 \mu \mathrm{g} / \mathrm{L}$ e $20 \mu \mathrm{g} / \mathrm{L}$, sendo que a parte inorgânica apresenta-se em baixas concentrações, uma vez que é consumida pelos organismos produtores. 


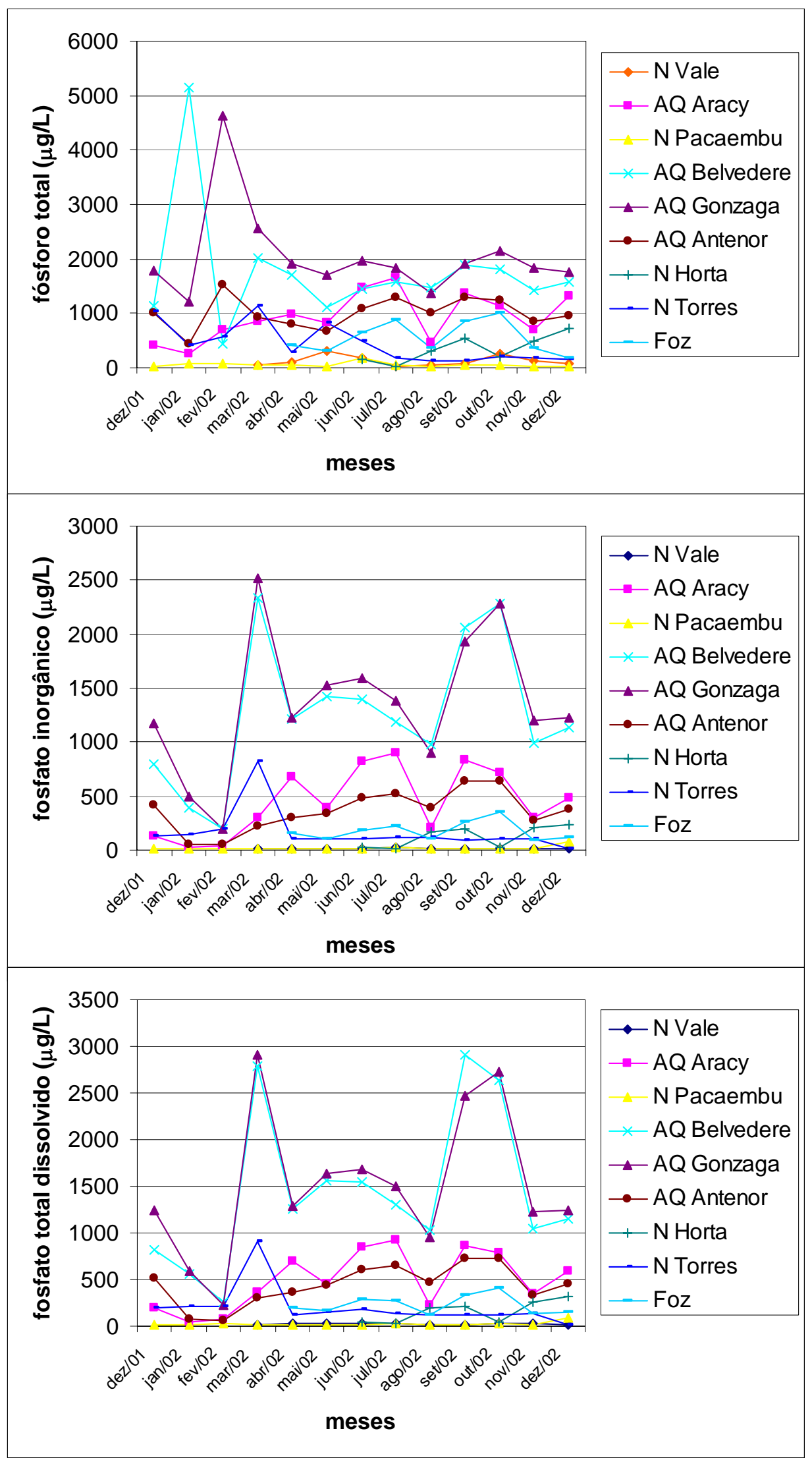

Figura 31: Variações espacial e temporal de fósforo total, fosfato inorgânico e fosfato total dissolvido ( $\mu \mathrm{g} / \mathrm{L})$ em nove pontos da MCAQ entre dezembro de 2001 e dezembro de 2002. 
Por outro lado, as menores concentrações das formas fosfatadas ocorreram nas nascentes N-Vale e N-Pacaembu. A N-Pacaembu apresentou os menores valores de fósforo total, entre 15,2 $\mu \mathrm{g} / \mathrm{L}$ (agosto de 2002) e 169,5 $\mu \mathrm{g} / \mathrm{L}$ (junho de 2002), e os menores valores de fosfato total dissolvido, entre 11,7 $\mu \mathrm{g} / \mathrm{L}$ (novembro de 2002) e 29,9 $\mu \mathrm{g} / \mathrm{L}$ (julho de 2002), com um pico de 96,6 $\mu \mathrm{g} / \mathrm{L}$ em dezembro de 2002. Na N-Vale, o fosfato total dissolvido manteve-se sempre abaixo de $36,0 \mu \mathrm{g} / \mathrm{L}$, com concentração mínima de $15,7 \mu \mathrm{g} / \mathrm{L}$.

Em comparação com os níveis aceitáveis de fósforo total (para córregos classe 2, como é o caso do Córrego da Água Quente, $0,1 \mathrm{mg} / \mathrm{L}$ ) segundo a resolução CONAMA 20, alterada pela resolução $357 / 05$, todos os pontos de coleta apresentaram em alguns ou em todos os momentos, concentrações superiores. Somente nas nascentes ocorreram concentrações abaixo de $100 \mu \mathrm{g} / \mathrm{L}$.

Os valores de fosfato inorgânico obtidos nos pontos com menor concentração, mantiveram-se abaixo de $20 \mu \mathrm{g} / \mathrm{L}$ na $\mathrm{N}-$ Vale, e abaixo de $22,3 \mu \mathrm{g} / \mathrm{L}$ na N-Pacaembu, com exceção do mês de dezembro em que chegou a $84,5 \mu \mathrm{g} / \mathrm{L}$ na N-Pacaembu.

Santos (1993) estudando o Córrego Água Quente, encontrou os seguintes valores para o ano de 1990. Na estação seca, o fósforo total esteve entre 284,58 $\mu \mathrm{g} / \mathrm{L}$ (nascente) e 668,27 $\mu \mathrm{g} / \mathrm{L}$ (foz), e ao longo do córrego esteve entre 556,61 $\mu \mathrm{g} / \mathrm{L}$ e $632,74 \mu \mathrm{g} / \mathrm{L}$. Na estação chuvosa, os valores de fósforo total obtidos foram $205,47 \mu \mathrm{g} / \mathrm{L}$ no córrego e $376,82 \mu \mathrm{g} / \mathrm{L}$ na nascente.

Quanto ao fosfato inorgânico, Santos (1993) obteve na estação seca os valores de 3,38 $\mu \mathrm{g} / \mathrm{L}$ na nascente, e entre $41,34 \mu \mathrm{g} / \mathrm{L}$ e $147,95 \mu \mathrm{g} / \mathrm{L}$ no córrego. E na estação chuvosa, entre 6,69 $\mu \mathrm{g} / \mathrm{L}$ e $86,31 \mu \mathrm{g} / \mathrm{L}$ no córrego, e $29,6 \mu \mathrm{g} / \mathrm{L}$ na nascente. Para o fosfato total dissolvido, obteve, na estação seca $5,52 \mu \mathrm{g} / \mathrm{L}$ na nascente e entre 56,87 $\mu \mathrm{g} / \mathrm{L}$ e 178,45 $\mu \mathrm{g} / \mathrm{L}$ no córrego; na estação chuvosa, obteve $31,88 \mu \mathrm{g} / \mathrm{L}$ na nascente e entre $24,36 \mu \mathrm{g} / \mathrm{L}$ e $103,89 \mu \mathrm{g} / \mathrm{L}$ no córrego.

Foi possível constatar que as nascentes N-Vale e N-Pacaembu apresentaram concentrações constantemente baixas das formas fosfatadas.

Para os demais pontos, nota-se que além das altas cargas de nutrientes, outro fator que afetou fortemente a qualidade do sistema foi a grande quantidade de material em suspensão. Esse material modifica a radiação solar no córrego e prejudica a atividade fotossintética dos produtores, além de reduzir o volume de água do córrego devido ao assoreamento. Disto decorre alguns momentos dos meses de coleta, onde o fosfato inorgânico é suplantado pelas concentrações de fosfato orgânico do sistema. 
Conforme Rios (1993), que estudou o Ribeirão do Feijão, o principal corpo d'água que abastece São Carlos, averiguou que mais do que a topografia e a erodibilidade do solo, o fator principal que influencia no aumento de sedimentos transportados para os cursos d'água pelo escoamento superficial é o uso inadequado do solo.

\section{Turbidez}

Os valores encontrados para a turbidez estão no Anexo 9 e na Figura 32.

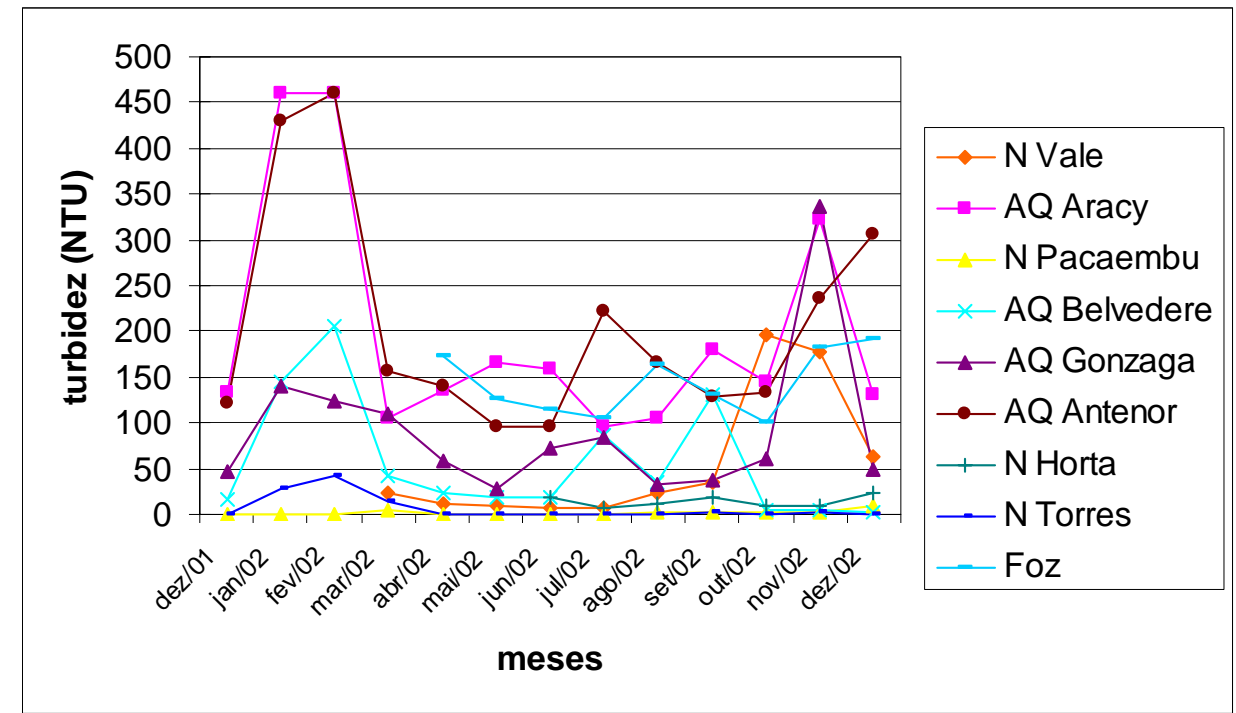

Figura 32: Variações espacial e temporal de turbidez (NTU) em nove pontos da Microbacia do Córrego da Água Quente (São Carlos-SP) entre dezembro de 2001 e dezembro de 2002.

De maneira geral, os valores de turbidez nos pontos AQ-Aracy e AQ-Antenor foram os mais elevados, principalmente nos meses de janeiro e fevereiro de 2002 (estação chuvosa), em que se mantiveram entre 430 NTU e 461 NTU. Também na estação seca, o maior valor de turbidez foi encontrado no AQ-Antenor, sendo 221 NTU em julho de 2002.

Os maiores valores foram observados no período chuvoso, correspondendo aos índices mais elevados de precipitação e de concentração de material em suspensão na água. Os menores valores de turbidez foram observados para as nascentes N-Pacaembu (sempre abaixo de 4 NTU, exceto em dezembro de 2002 que atingiu 9 NTU) e NTorres (sempre abaixo de 2 NTU, exceto nos meses de janeiro a março de 2002, com picos de 29 NTU, 43 NTU e 13 NTU, respectivamente). Esses valores extremos obtidos no N-Torres estão relacionados com o período chuvoso e com o despejo de efluentes 
domésticos nesses meses, devido à quebra da tubulação de esgoto. Os valores de turbidez da nascente N-Vale (entre 6 NTU e 197 NTU), podem ser atribuídos ao pisoteamento por cavalos, uma vez que a nascente era usada para a dessedentação desses animais.

\section{Coliformes totais e fecais}

Embora as análises de coliformes (totais e fecais) não tenham abrangido todo o período de amostragem, os resultados obtidos evidenciam a necessidade de estudos mais detalhados sobre o aspecto sanitário das águas do Córrego da Água Quente e, especialmente, de suas nascentes. Essas águas são utilizadas para dessedentação de animais que usam o local como área de pastagem, e toda a área verde é freqüentada por muitas pessoas, principalmente crianças.

Em ambos os períodos - chuvoso e seco - foi observada uma quantidade extremamente elevada de coliformes em todos os pontos no Córrego da Água Quente, sempre acima de 2.419 NMP, o que indica que a água é inadequada para todos os tipos de usos indicados pela Resolução CONAMA 20 (modificada em 17/03/05, e reeditada sob número 358).

Em relação às nascentes, foram encontrados para a N-Pacaembu os seguintes valores mínimos e máximos: zero NMP em janeiro e agosto de 2002 e 2.350 MPN em fevereiro de 2002. Na N-Vale, foi realizada a análise de coliformes somente no período seco, obtendo-se valores entre 200 NMP em junho e zero NMP em agosto. Na NTorres, os valores mínimos e máximos foram 34 MPN em dezembro de 2001 e acima de 242 MPN em janeiro de 2002.

Os valores acima, obtidos a partir da análise da água das nascentes, indica uma grande variação na presença de coliformes fecais entre os meses coletados, o que demonstra que a ingestão dessas águas pode apresentar riscos à saúde. 


\subsection{Análise estatística dos dados}

Foi realizada uma Análise de Componentes Principais (ACP) para se elucidar a tendência que certas variáveis possuíam em influenciar a qualidade da água. A partir dos dados coletados, foi estabelecida uma matriz de correlação entre as variáveis.

No presente estudo observou-se que os Eigen-valores de F1 correspondem a 47,6\% da variância e para F2 os valores representam 19,8\% da variância. Os dois eixos podem ser utilizados para as inferências da ACP, pois juntos explicam 67,49\% da variabilidade (Figura 33).

Através do gráfico do cruzamento dos eixos F1 e F2 (Figura 34), observa-se que as formas fosfatadas e o nitrogênio orgânico total foram os principais responsáveis pela variabilidade dos dados. Os Eigen-valores para estas variáveis são as maiores dentro do eixo 1. Ou seja, foram as variáveis que mais influenciaram e de modo semelhante na qualidade da água. Suas concentrações foram elevadas nos pontos onde ocorre despejo de efluentes domiciliares, o que pode explicar o resultado obtido pela ACP.

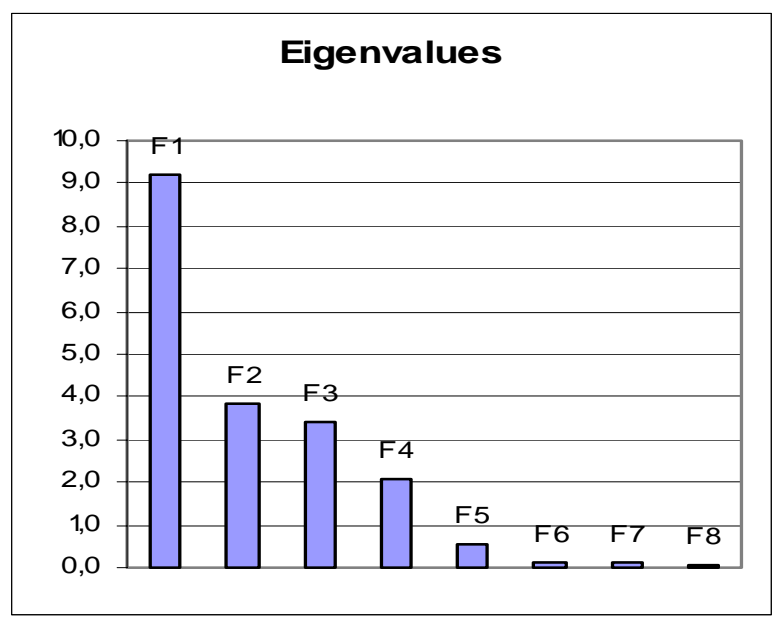

FIGURA 33 - Proporção de Eigen-valores e sua representatividade na variância dos dados. 


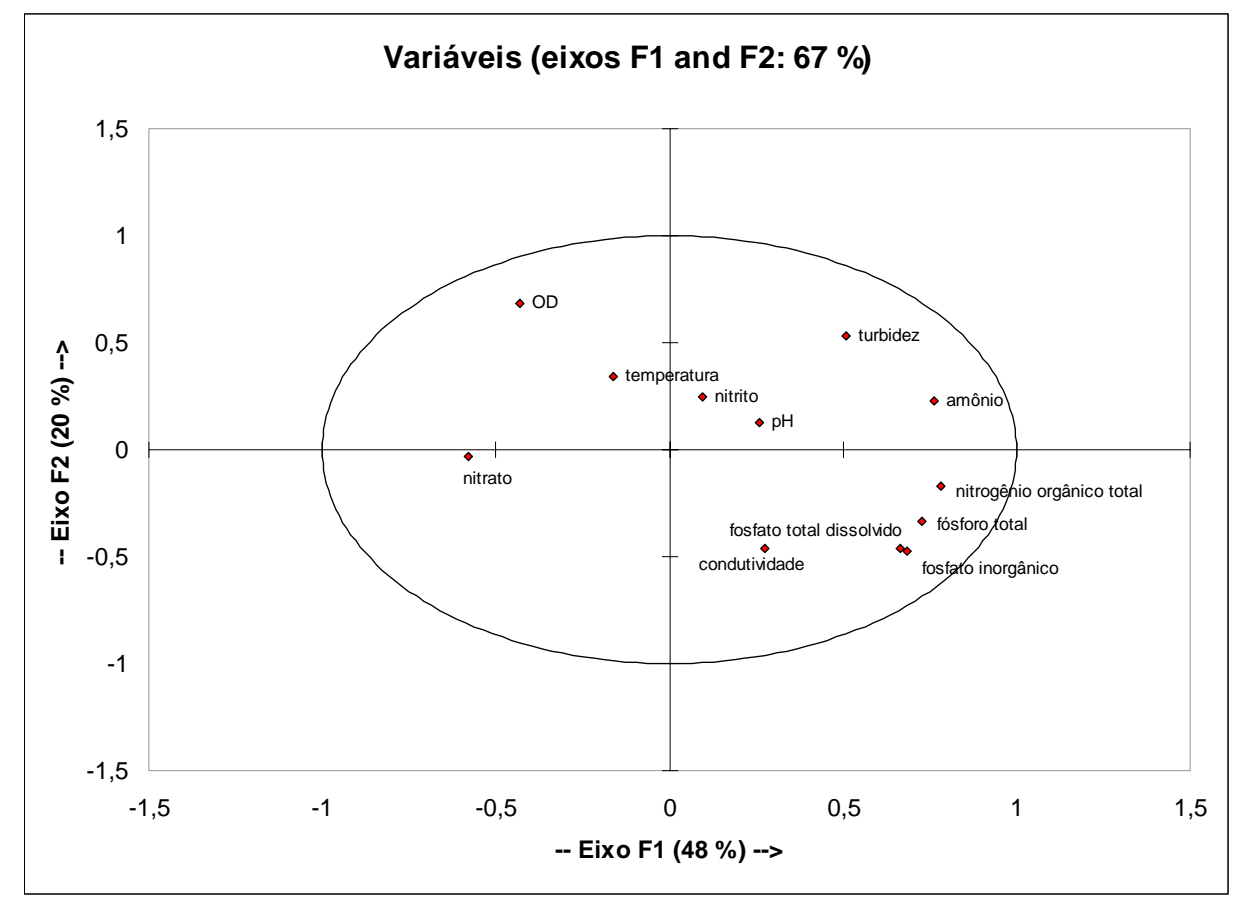

Figura 34: Resultado da ACP, demonstrando o alto grau de interferência do nitrogênio orgânico total e formas fosfatadas (canto direito inferior).

Através de uma análise de fator discriminante, os componentes principais dos eixos F1 e F2 puderam evidenciar 3 grupos distintos de pontos (Figura 35):

Grupo 1: nascentes, com menor impactação de origem antrópica.

1 - N-Vale (nascente do Vale, próxima ao Bairro Cidade Aracy)

3 - N-Pacaembu (nascente próxima à Avenida Pacaembu)

7 - N-Horta (nascente localizada na horta de uma Chácara)

8 - N-Torres (nascente próxima ao Jardim das Torres)

Grupo 2: Pontos localizados no córrego, com processo de auto-depuração e sem mata ciliar, com acentuado assoreamento resultante da erosão das margens.

2 - AQ-Aracy (trecho do Córrego da Água Quente próximo ao bairro Cidade Aracy)

6 - AQ-Antenor (trecho do Córrego da Água Quente próximo ao bairro Loteamento Social Antenor Garcia) 
9 - Foz (trecho final do Córrego da Água Quente próximo ao encontro com o Rio Monjolinho)

Grupo 3: Pontos com forte despejo de resíduos (efluente domiciliar)

4 - AQBelvedere (trecho que recebe as águas da nascente do Pacaembu e águas servidas dos bairros acima)

5 - AQGonzaga (trecho que recebe as águas do AQ Belvedere e as águas servidas do Jardim Gonzaga e Monte Carlo.

A Figura 35 apresenta o agrupamento destes pontos, de acordo com os componentes principais.

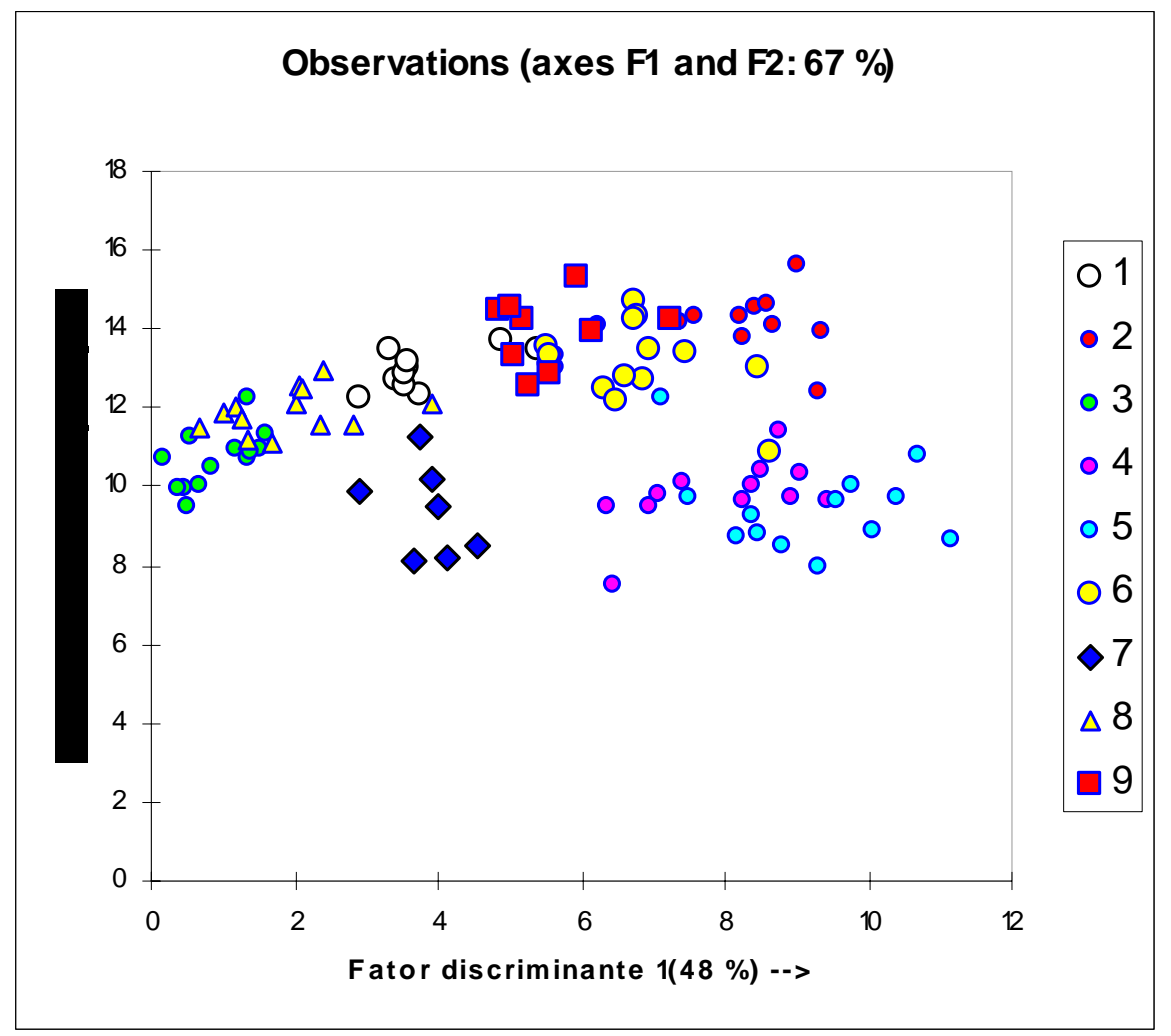

Figura 35: Agrupamentos de pontos, segundo critérios da análise de componentes principais e de fator discriminante.

Pelos resultados apresentados observa-se que, em relação à qualidade da água do Córrego da Água Quente, as variáveis referentes às formas fosfatadas e o nitrogênio 
orgânico total foram os principais responsáveis por determinar a má qualidade da água nos trechos com forte impactação. Há pontos significativamente diferentes quanto à qualidade da água e é possível estabelecer a provável causa desta degradação.

Isto reflete a real situação segundo os levantamentos em campo. Este fato é importante, pois demonstra que a interpretação dos dados limnológicos apresenta coerência com a realidade, juntamente com a observação in loco e a análise de informações perante a literatura, tendo com subsídio a significância estatística que corrobora com tais dados.

\subsubsection{USO E OCUPAÇÃO DA MICROBACIA E AS CONSEQÜÊNCIAS SOBRE A ÁREA VERDE}

Nas cidades, a exclusão social é também ambiental na medida em que os setores empobrecidos da população são, sem dúvida, os mais expostos à carência de qualidade ambiental. Neste contexto, a Educação Ambiental vem alertar para essa realidade e possibilitar a mudança de valores, o reconhecimento do direito à cidadania $\mathrm{e}$ o papel de cada indivíduo na conservação e melhoria de seu habitat.

Em termos de ocupação urbana, vários bairros da microbacia constituem hoje algumas das áreas mais críticas da cidade, por possuirem uma problemática que envolve questões habitacionais, urbanísticas, ecológicas, sociais e políticas graves, desde sua origem. Além disso, embora já consolidados na malha urbana, esses bairros apresentam alguns trechos com inúmeras carências no que diz respeito à infra-estrutura, como coleta de esgoto, pavimentação de vias, acesso de pedestres, drenagem de águas pluviais, necessidade de contenção de encostas, erosão e resíduos sólidos, entre outras. Esses bairros em geral apresentam uma implantação e uma configuração viária peculiares devido à topografia acidentada e possuem trechos implantados junto a uma área verde, sem respeitar os limites de proteção ambiental impostos pela lei.

A ocupação desordenada e ilegal de parte desse remanescente de vegetação natural da bacia a partir da década de 70 trouxe sérios problemas ambientais, pois tratase de uma área inadequada para ocupação devido à declividade e às características do solo que favorecem o processo de erosão e ainda, pela falta de infra-estrutura urbana (asfalto, redes pluvial e de efluentes domiciliares), ocorreram, como já foi comentado, grandes erosões e o assoreamento do Córrego da Água Quente e de suas nascentes. 
Sé (1992), ao estudar a Bacia Hidrográfica do Rio do Monjolinho, delineou os seguintes mecanismos modificadores da qualidade da água presentes no leito e vizinhanças do rio: tipos de substrato, características geomorfológicas (trechos planos, corredeiras), entrada de águas subterrâneas e afluentes, presença ou não de vegetação ciliar, comunidade biológica em trânsito ou fixada nos trechos, regime climático e interferência antrópica (dinâmica de usos múltiplos do rio e da bacia como um todo). Para esse autor, o sistema socioeconômico-político, a influência que esse sistema complexo exerce sobre os cidadãos, a pouca informação sobre os processos ecológicos que definem a dinâmica ambiental por falta de pesquisa científica, e a falta de compreensão sobre a dependência dos seres humanos em relação à bacia hidrográfica, levaram a uma ocupação desordenada da bacia que não respeita seus mecanismos naturais, levando à destruição de ecossistemas nativos.

O desequilíbrio desses ecossistemas (matas de encosta e ciliares, cerradões, cerrados e sistemas aquáticos) traz sérias conseqüências uma vez que estes funcionam como estabilizadores de ecossistemas maiores, sendo responsáveis pela reciclagem mais eficiente de nutrientes, a proteção contra a erosão pluvial e fluvial, a regulação térmica da bacia, a manutenção da biodiversidade do local, entre outras funções ambientais (SÉ, op. cit.).

Neste contexto, a conservação dos componentes naturais (flora, fauna, solo, nascentes e córrego) da área verde da MCAQ foi prejudicada, acarretando em um ambiente insalubre e ecologicamente alterado. A flora foi a primeira a sofrer prejuízos com a ocupação humana, uma vez que os loteamentos dirigidos ao público de baixo poder aquisitivo, via de regra, não se preocupam com a qualidade ambiental, retirando toda a cobertura vegetal original para a implantação dos mesmos, e não destinando áreas livres para lazer da população, previstas por lei.

As zonas adjacentes representadas pelas regiões de cuestas (próximas ao bairro Jardim Gonzaga) e que formam um fundo de vale estão entre os poucos trechos onde ainda existe cobertura vegetal nativa, porém perturbada, isto porque a acentuada declividade e o solo rochoso barraram a expansão da malha urbana possibilitando a permanência de remanescentes da flora original.

Não obstante as salvaguardas naturais, são evidentes o adiantado grau de degradação e o risco de desaparecimento de todo esse remanescente de vegetação nativa e dos corpos d'água, acentuados pelas constantes queimadas, pela insuficiência de 
saneamento básico (efluentes domésticos in natura lançados na encosta) e pela disposição de grandes quantidades de resíduos sólidos no solo (principalmente entulhos de construção) e nos corpos d'água. Esta situação exige a busca de projetos que conciliem o resgate da cidadania dos habitantes do entorno dessa área com a melhoria e conservação da qualidade ambiental.

As relações entre a ocupação irregular de uma região da MCAQ e da ausência de um manejo adequado, foram estudadas por TÓRO-TONISSI et al. (1999), e demonstradas através de uma rede de interação (Figura 36).

\section{REDEDE INIERAÇÃODOS IMPACTOS AMBIENTAIS DAOOUPAÇÃOIRREGULAREM ÁREADERISCO \\ (Ocaso Jardim Gonzaga - São Carlos/SP)}

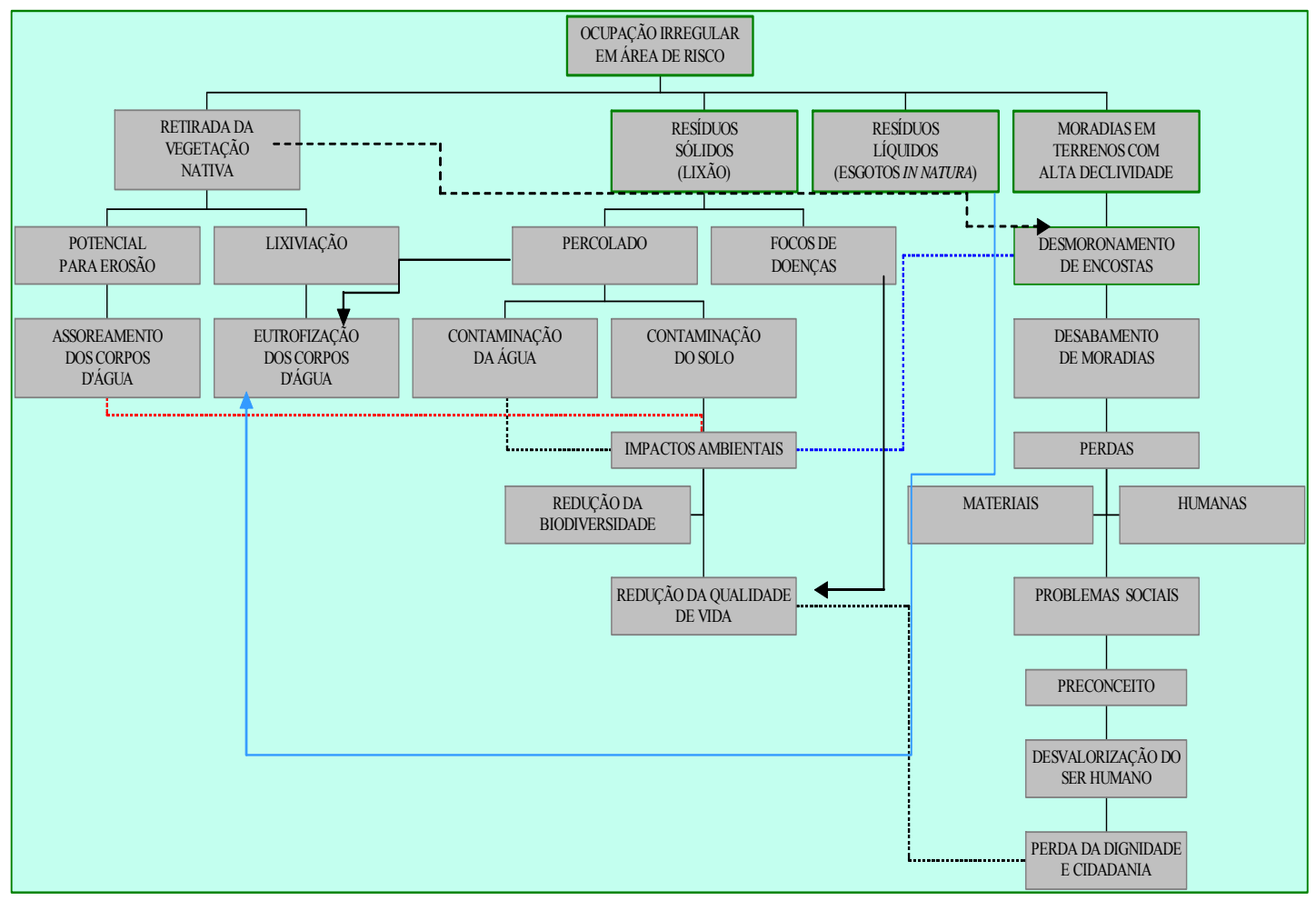

Figura 36: Síntese das inter-relações entre os impactos ambientais da ocupação irregular no bairro Jardim Gonzaga. 


\subsubsection{SÍNTESE DA CARACTERIZAÇÃO AMBIENTAL DA ÁREA VERDE}

A Microbacia do Córrego da Água Quente apresenta várias peculiaridades ambientais. Está inserida em uma área cuja vegetação original caracterizava-se por fisionomias de Cerrado, Cerradão, Mata Ciliar e de Floresta Estacional Semidecídua. Atualmente, essas formações vegetais foram totalmente alteradas, reduzindo-se basicamente a uma área verde próxima ao Córrego da Água Quente. Essa modificação na composição vegetal está intimamente associada com a redução da diversidade e do número de espécies da fauna e de outros grupos de organismos.

As alterações no ecossistema original deveram-se à ocupação urbana mal planejada, que deu origem a processos erosivos de proporções gigantescas, ao desmoronamento de margens devido à retirada de vegetação e à descaracterização do ambiente natural com a presença de lixo e entulho.

Estas características são refletidas sobre o Córrego da Água Quente e suas nascentes, uma vez que estes recebem todo o impacto (positivo ou negativo) advindo da pressão urbana, bem como da existência ou não de cobertura vegetal.

As altas entradas de nutrientes, marcadamente as formas nitrogenadas e fosfatadas presentes no CAQ, aparecem em decorrência dos efluentes domésticos. A rede de esgoto, por enquanto incompleta, despeja altas cargas de poluentes deste tipo para dentro do Córrego da Água Quente.

Além deste fato, a ausência de cobertura vegetal ripária favorece a lixiviação pela chuvas, ventos e pisoteamento de animais, de grande quantidade de material particulado para os corpos d'água, que pode ser verificado pelos valores de condutividade (devido ao carreamento de íons) e turbidez.

A alta entrada de compostos deste tipo acarreta intenso processo de decomposição do material orgânico, desencadeando com isso, diminuição do oxigênio dissolvido e alteração no equilíbrio químico da produção de compostos nitrogenados e da utilização de recursos pela biota, bem como sua sobrevivência.

As nascentes apresentam a melhor situação ambiental, com baixas condutividades e concentrações de nutrientes, além de concentrações elevadas de oxigênio. Nas nascentes (exceto na N-Horta) ocorre ainda a presença de alguma vegetação ripária, que as protege reduzindo os danos ambientais. Ao longo do rio, esta 
proteção foi praticamente perdida, ocasionando, associada à fragilidade do solo e ao pisoteamento por animais, o acelerado estado de assoreamento do córrego.

O uso inadequado desta área verde tem causado uma série de impactos ambientais como a descaracterização da paisagem pelo desmatamento, queimadas, erosão, assoreamento e presença de resíduos ou efluentes, e muitas vezes tem oferecido riscos à saúde das pessoas que com ela convivem. 
5.2 PERCEPÇÃO AMBIENTAL, TOPOFILIA E SABERES LOCAIS DA COMUNIDADE DA MICROBACIA DO CÓRREGO DA ÁGUA QUENTE EM RELAÇÃO À ÁREA VERDE

\subsubsection{PERFIL DAS PESSOAS ENTREVISTADAS}

As questões de 01 a 04 (gênero, faixa etária, procedência e tempo de residência na microbacia) serviram para apresentar a(o) entrevistada(o) do ponto de vista das características socioeconômicas, e também para que, após essa primeira parte do diálogo, a pessoa pudesse se sentir mais descontraída para responder as questões específicas sobre percepção ambiental e conhecimento da área. Todas as entrevistas puderam ser utilizadas na pesquisa, uma vez que todas as pessoas participantes preencheram os pré-requisitos necessários para participação que estabelecemos, sendo maiores de 18 anos e residentes na MCAQ há pelo menos 5 anos.

A questão 01 identificou as(os) entrevistadas(os) por gênero, e está representada na figura 37. Foram entrevistadas(os) 22 mulheres e 18 homens.

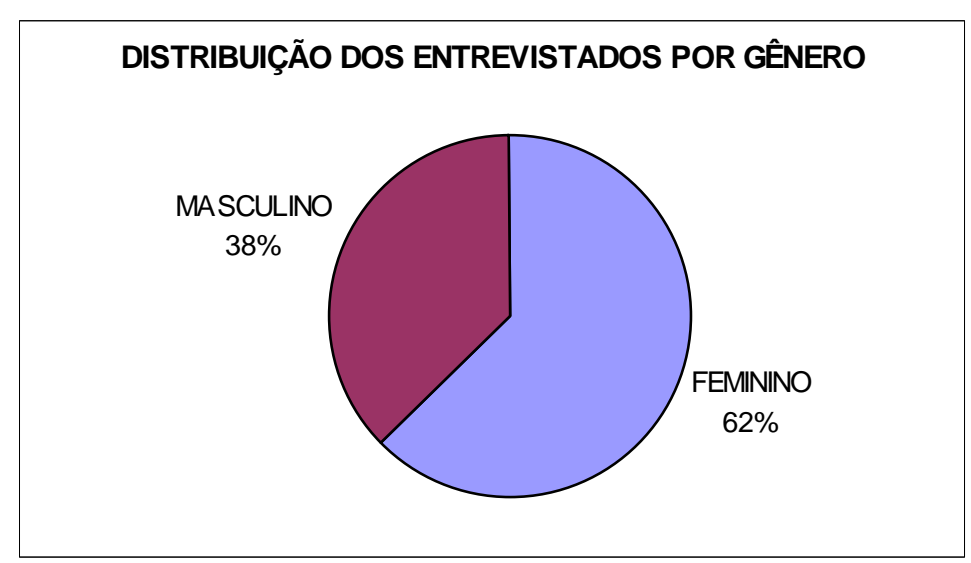

Figura 37: Gênero das pessoas entrevistadas.

A faixa etária das(os) entrevistadas(os) foi abordada na questão 02 (Figura 38), podendo-se observar uma distribuição com uma concentração entre 18 a 20 anos (25\% das pessoas) e entre 51 e 60 anos (17,5\% das pessoas). 


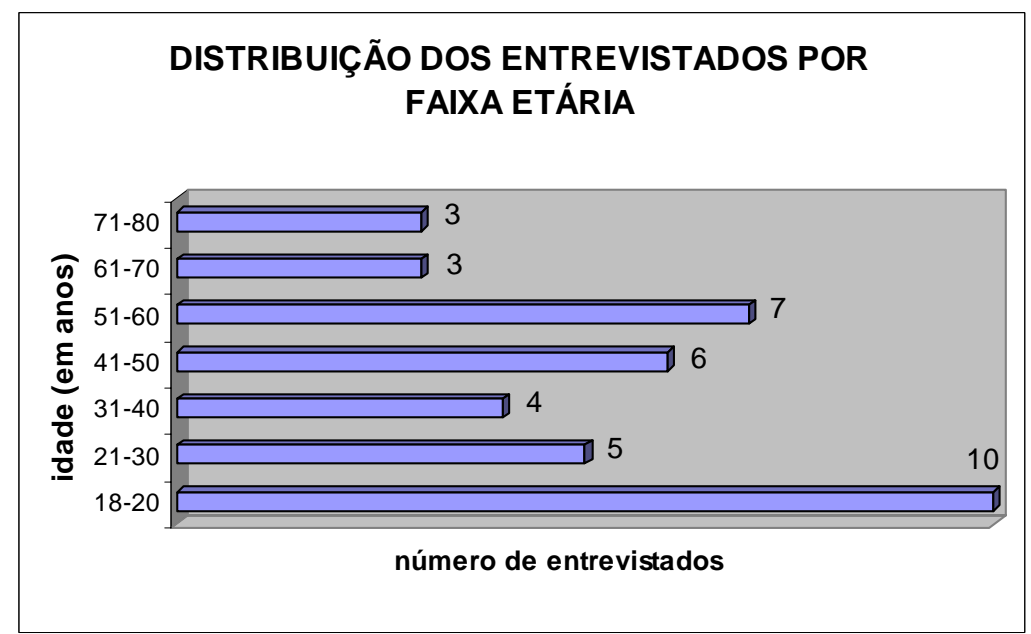

Figura 38: Faixa etária das(os) entrevistadas(os).

A Figura 39 mostra a relação de estados e regiões de procedência das(os) participantes, o que indica que $70 \%$ são migrantes, dos quais $32,5 \%$ vieram de outros estados.
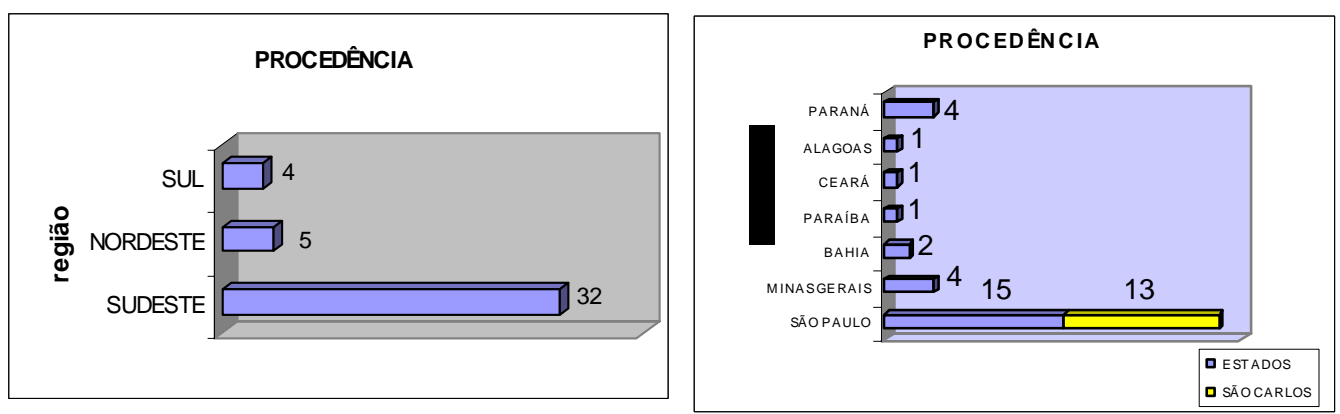

Figura 39: Procedência das pessoas entrevistadas quanto ao estado e à região.

A Figura 40 apresenta uma relação entre o tempo de residência das(os) entrevistadas(os) na microbacia, sendo que o tempo médio é de 16 anos. 


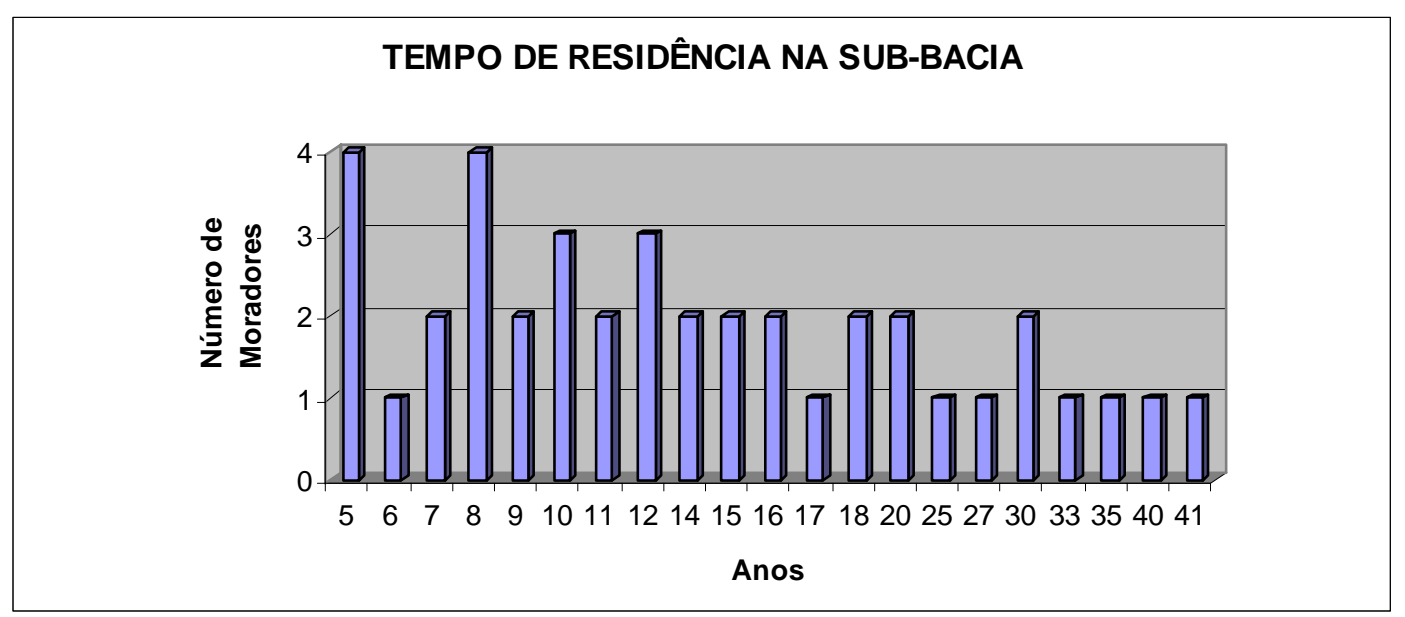

Figura 40: Tempo de residência das pessoas entrevistadas na Microbacia do Córrego da Água Quente.

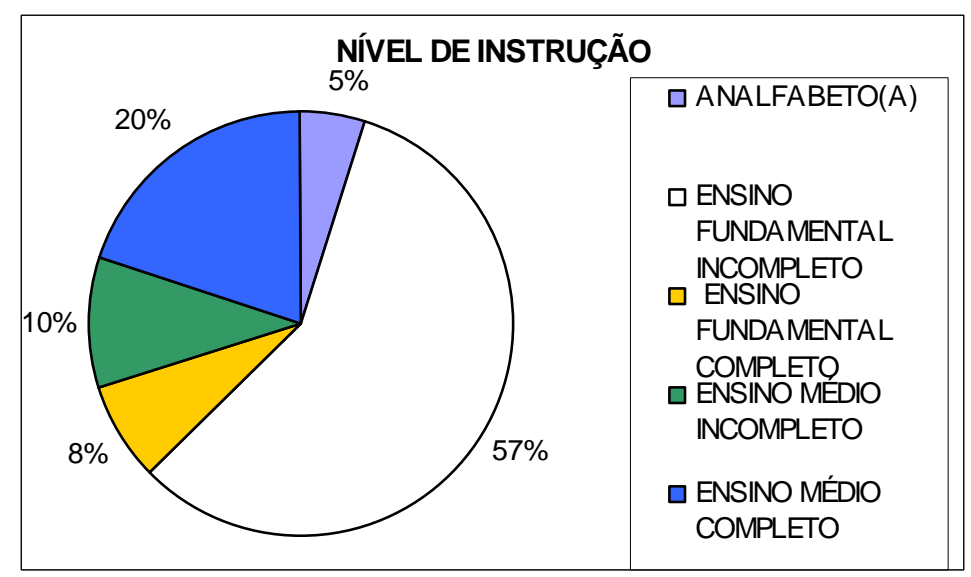

Figura 41: Nível de instrução escolar das pessoas entrevistadas.

A questão 05 referia-se ao nível de instrução escolar das(os) entrevistadas(os) e os resultados estão apresentados na Figura 41. Estes dados mostram uma predominância de entrevistadas(os) com ensino fundamental incompleto (57\%), que são na maioria pessoas adultas e idosas, e $20 \%$ com ensino médio completo, na maioria jovens com menos de 25 anos.

Nas questões de 06 a 12, sobre tamanho da família, situação de trabalho, profissão, atividade econômica principal, renda familiar e tipo de domicílio, pudemos verificar que a maioria das pessoas entrevistadas possui baixo poder aquisitivo, e em relação ao perfil sociocultural a maioria respondeu que vai à igreja, visita parentes, 
assiste TV e ouve rádio, sendo que os programas preferidos são os de entretenimento e telejornais, e os canais mais assistidos são as Rede SBT e Globo. Na Figura 42 está a relação das religiões das(os) respondentes, sendo 59\% católicos, 36\% evangélicos de diferentes denominações e $5 \%$ sem religião, e os que são praticantes disseram que poucas vezes ouviram em suas igrejas assuntos relacionados ao meio ambiente.

Uma pessoa citou a Campanha da Fraternidade promovida pela Conferência Nacional de Bispos do Brasil (CNBB), cujo tema foi "Fraternidade e Água", e outra disse que em sua igreja de vez em quando há palestras sobre diferentes assuntos, inclusive assuntos ambientais.

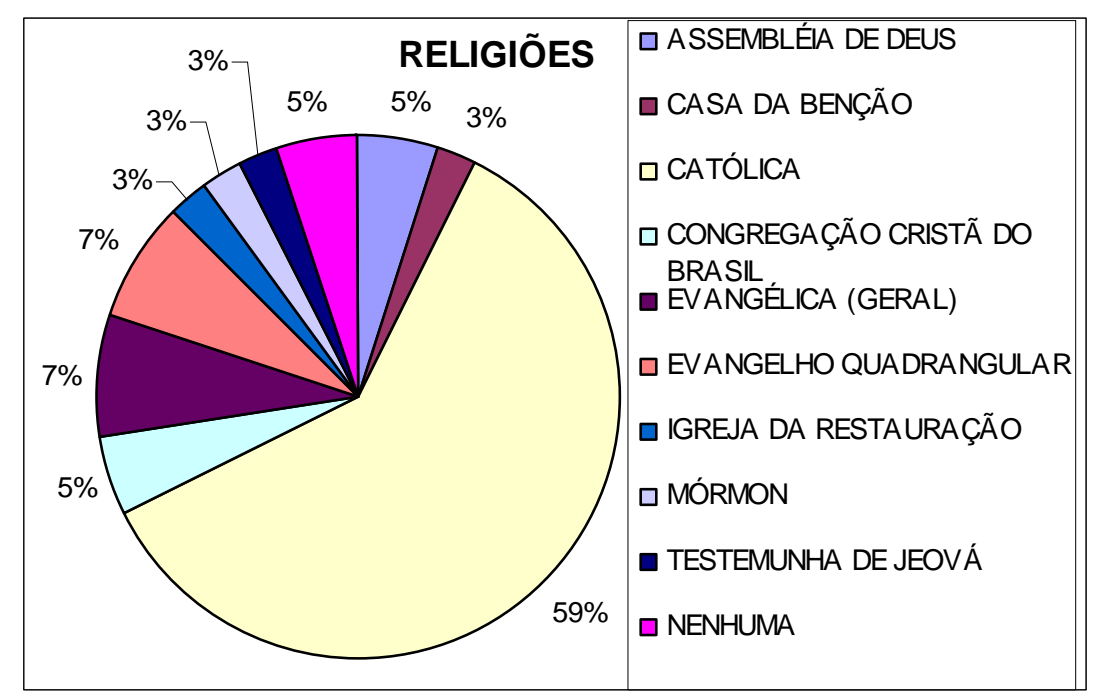

Figura 42: Religiões das pessoas entrevistadas.

De modo geral, as pessoas não têm hábito de leitura de nenhum jornal ou revista, e somente duas pessoas, um homem e uma mulher, afirmaram participar de associação de bairro, podendo-se perceber a falta de informação e de mobilização da grande maioria da comunidade.

\subsubsection{PERCEPÇÃO AMBIENTAL E TOPOFILIA DA COMUNIDADE DA MICROBACIA EM RELAÇÃO À ÁREA VERDE}

O estudo da percepção foi baseado nas questões de 16 a 30 da entrevista, cujos resultados estão apresentados a seguir. 


\section{Questão 16: Em sua opinião, como deve ser um bom lugar para se viver na cidade?}

O objetivo desta pergunta foi analisar quais as características ambientais que a população relaciona com um bom lugar para se viver na cidade, com que freqüência cada uma delas apareceu nas respostas, e quais indicadores são considerados como positivos ou negativos pela comunidade. As respostas foram classificadas em três categorias (componentes naturais, relações interpessoais e componentes construídos, conforme a figura 43), divididas nos quadros de 5 a 7 :

\section{COMPONENTES NATURAIS DO AMBIENTE \\ ÁGUA (RIO, CÓRREGO, MINA, NASCENTE) - indicador positivo}

"Aquela água mesmo (da área verde) é uma coisa que devia tratar, até pra servir o bairro inteiro. Então eu me preocupo mais com aquela água ali, que é uma água que desde criança a gente bebia ela, sem precisar ferver, sem precisar nada. Tem uma mina lá, ela é no barranco, ela solta aquela água e é térmica. É ali mesmo no Gonzaga, mas descendo o Buracão".

VEGETAÇÃO (ÁREA VERDE, MATA, MATO, ÁRVORES, PLANTAS) - indicador positivo

"Tem que ter árvore pra ficar mais bonita, a gente se sente melhor. E a limpeza também. Não adianta ter aí (a mata) e não limpar, eu mesma já mandei limpar aí, que é bonito, mas se limpinho”.

"E o que tem de mata tem que ser preservado. Senão não adianta nada, o que a gente vai fazer com tanta casa se não tem nenhum pouquinho de mata? Tem o mato, mas estão tirando o que tem".

"Perto da vegetação".

"Com bastante verde".

PAISAGEM - indicador positivo

"Tem bastante mata, tem um rio bem bonito, morar perto do verde".

"Eu não entendo muitas coisas sobre mata, lá em Minas a gente andava bastante na mata, apanhava lenha, via os bichinhos, via tatu, via cobra, mas aqui eu nunca fui pra esse mato aí. Quer dizer, tem muitos passarinhos, muitos bichinhos assim, mas eu nunca fui lá não. Eu só vou no lixo ali na beiradinha e volto pra casa de novo".

AR

Indicador positivo

"Um bom ar".

Indicador negativo

"Principalmente acabar com essa poeira, porque essa poeira acaba comigo, que tenho alergia de poeira”.

FAUNA (VERTEBRADOS, INSETOS) - indicador negativo

“E tem essa sujeira, então tem época que tem pernilongo, mosquito”.

"Esses matos aí (terreno baldio em frente à casa), você passa aqui daqui uns 20 dias o tamanho que está isso aí já não é certo, então se um vizinho pega e carpe um pedaço cada um já alivia bastante, porque a situação está difícil, e aqui pra esse lado tem muita cobra, dentro da casa da minha mãe foi 
pego três cobras, a última delas cataram, minha mãe dormindo 6 horas da manhã, meu pai chegou do serviço foi deitar, a cobra embaixo do travesseiro, uma coral. Uma irmã minha levantou, a cobra passou em cima do pé dela, coral também, e a outra dentro do fogão do vizinho".

\section{IMPACTOS AMBIENTAIS - indicador negativo}

"Sem poluição, sem desmatamento".

Quadro 5: Componentes naturais que influenciam na qualidade ambiental.

Neste quadro, pode-se observar que somente 12 pessoas $(30 \%)$ relacionaram o componente natural do ambiente com a qualidade ambiental. Dentre os componentes naturais, a vegetação é o que mais aparece, sempre com conotação positiva e no sentido de que as áreas com vegetação devem ser limpas (sem lixo), recuperadas e conservadas, pois é bom morar em locais próximos a áreas de vegetação natural. A fauna aparece em duas respostas, sempre com sentido negativo, relacionando a presença de animais, com a "sujeira" do ambiente (insetos como mosquito, pernilongo) ou com situações de perigo em que animais 'invadem' espaços do ser humano. Uma pessoa cita a existência da água próximo ao local em que vive, com um fator positivo, ou seja, que a qualidade da água do "Buracão" (nome referente à área verde) deve ser recuperada para que volte a ser boa como no passado, em que as pessoas a consumiam sem nenhum tipo de tratamento. A paisagem aparece em duas respostas, sempre no sentido positivo, sendo que na primeira é composta por água e vegetação, e na segunda remete a uma paisagem do passado, composta por vegetação e fauna, e que deixou saudade. Um respondente refere-se a dois impactos ambientais (poluição e desmatamento) que, segundo ele, prejudicam o que seria considerado "um bom lugar para se viver".

Embora a ênfase deste trabalho seja a percepção ambiental da comunidade local em relação à área de vegetação natural como indicador de qualidade ambiental, a maioria das respostas evidenciou a predominância de outros indicadores $(38 \%$ se referiram às relações interpessoais e $45 \%$ aos componentes construídos). Por esse motivo, foram realizadas algumas interpretações a partir desses outros indicadores, inclusive por entender que o ser humano e todas as modificações que dele derivam, são também componentes ambientais e influenciam sobremaneira na qualidade ambiental de um lugar. 


\section{RELAÇÕES INTERPESSOAIS \\ VIZINHANÇA \\ Indicador positivo \\ "Deve ter paz. É melhor um bairro do que no centro da cidade. No bairro eu tenho mais amizade com os outros do que no centro. Lá é pros bom da boca, mas que nem nós mesmo tem que ficar aqui”.}

"Se dar bem com os vizinhos é muito importante”.

“Ter paz, um lugar pra ser bom a gente tem que conhecer o vizinho da gente também, né?”

"Os moradores, se tem amizade, não tem malquerência, tudo em paz, meus vizinhos são todos bons pra mim, eu gosto de morar aqui”.

“Pra ser bom, o que faz é o povo, viu? O povo é que faz um bairro bom”.

“Com bons vizinhos”.

“Um bom lugar pra se viver na cidade deve ter bons vizinhos, boas amizades”.

“Uma boa união”.

\section{Indicador negativo}

"Na cidade é difícil, do jeito que está hoje as coisas, com essa malandragem que tem, nós não vive sossegado. Você sai de casa, os outros vai e rouba. Aqui tem uma molecadinha triste, nunca pegaram nada meu, mas se você sai, quando volta não tem nada; quebra telha, porta. Dá medo da gente sair, não tem jeito, só se for bem fechado".

"Todas as casas aqui têm grades altas porque tem um grupinho de marginais que entram e roubam mesmo, por causa de drogas. A gente tem amizade com eles, fora isso aí é tranqüilo”.

"Primeiramente um bom lugar seria onde não existiria droga, né? A população devia de trabalhar mais no seu bairro, porque você vê, muita gente mesmo não concorda, esses matos aí (terreno baldio em frente à casa), você passa aqui daqui uns 20 dias o tamanho que está isso aí já não é certo, então se um vizinho pega e carpe um pedaço cada um já alivia bastante”.

“Eu não gosto de viver aqui não, tem muita maldade, eu fico com o meu coração muito triste, gosto de viver em paz, eu não gosto de lugar como esse, não gosto mesmo. Eu estou aqui porque eu sou obrigada, mas gostar daqui jamais”.

"Um lugar com mais paz, mais unido, dar mais valor nas coisas que tem no bairro, em geral tem muita gente que não dá”.

SEGURANÇA

Indicador positivo

“Mais segurança pras pessoas ficarem mais tranqüilas”.

“Ter sossego na cabeça, todo lugar que você vai tem que ter sossego, sem violência”.

"Sem indústrias por perto, segurança, etc.”

“Com esse mundo da droga que está aí, tem que ter mais segurança”.

“Ter segurança”. (4 citações)

\section{Indicador negativo}

"Hoje tem muito perigo, muita violência, e acho que nem dentro da casa da gente não é um bom lugar não, viu?”

“Em São Carlos eu gostei, mas às vezes a gente tem até medo de sair na rua, eu gostaria que acabasse 
mais essas folias desses jovens, muito erro, mais segurança, sabe que a melhor segurança é a que vem do céu, mas também aqui na Terra a gente tem que ter, né?”

"É difícil, nem dentro da igreja nós não estamos seguros. As fazendas aqui já foram todas assaltadas, você não pode deixar a casa aqui pra ir ao médico, porque quando chegar não tem nada mais em casa. Cada dia que passa está tendo mais violência”.

"Um bom policiamento também que falta".

PREOCUPAÇÃO COM A COLETIVIDADE

Indicador positivo

"O que a pessoa pode ter na cidade é com a conservação, tanto da vida da pessoa que está vivendo ali como os demais outros. Ele não pode só pensar na vida dele, tem os demais, os outros. E de melhor para o povo, hoje nós estamos numa época difícil de falar em melhora. Eu acho que cada um deve cuidar da sua parte pra não prejudicar outro”.

\section{Indicador negativo}

"O pessoal que tem uma certa educação, então tem que ser uma gente mais ou menos com uma certa educação. Hoje a coisa está tão, que parece que o errado ficou certo e que o certo ficou errado".

Quadro 6: Relações interpessoais como elementos que influenciam na qualidade ambiental.

Para a categoria relações interpessoais, foram destacados três itens, sendo que o item mais freqüente (mais de $50 \%$ das respostas) é o do relacionamento com os vizinhos. Portanto, esse fator demonstra ser de grande significado para as(os) participantes. Dentre as 14 pessoas que falaram da vizinhança, 9 expressam-se de modo positivo, ou seja, falam da importância da boa vizinhança para se viver em um bom lugar. Todavia, 5 pessoas associaram a vizinhança a elementos relacionados à violência ou falta de segurança (drogas, assaltos, maldade). O item "segurança" foi apontado por 11 pessoas ( 7 com conotação positiva) e não se referiu a um grupo específico de pessoas que seriam as responsáveis por garanti-la ou prejudicá-la. Esse item pode significar que se a segurança foi tão lembrada pelas(os) respondentes, é um aspecto realmente preocupante no local em que residem, e pode estar intimamente associada ao item "vizinhança", ainda que isso não tenha sido explicitado nas respostas.

Os componentes construídos (quadro 7), foram destacados em 32 respostas (80\%), sendo subdivididos em três itens (infra-estrutura, lazer e organização e limpeza). Ao invés de ser incluído no item "infra-estrutura", "lazer" foi classificado como um item separado, devido ao grande número de vezes que apareceu nas respostas (11 vezes). Isso pode indicar uma carência da população em relação ao lazer, principalmente no que se refere ao lazer infantil, com foi especificado em algumas respostas. A falta de oportunidades de lazer pode estar estreitamente relacionada à violência existente no local de estudo, evidenciada no componente "relações 
interpessoais", pois durante as entrevistas pudemos verificar que muitas pessoas deixam de freqüentar a área verde como um espaço de lazer por medo da violência a ela associada. Já era esperado que aparecessem nas respostas vários elementos do ambiente relacionados à infra-estrutura (ou à falta desta), uma vez que as entrevistas foram realizadas em bairros que carecem de vários equipamentos públicos, de asfalto e de saneamento básico. Neste sentido, a atual administração municipal tem tomado várias providências, como a ampliação da rede de esgoto e de asfaltamento nesses bairros, além da construção de posto de saúde, centro comunitário, quadra de esporte e campo de futebol no Jardim Gonzaga para atender a este bairro e à Vila Monte Carlo. Em relação ao item "organização e limpeza", apontado por 10 pessoas, foi enfatizada a questão do lixo e de animais (cavalos) soltos pelo bairro.

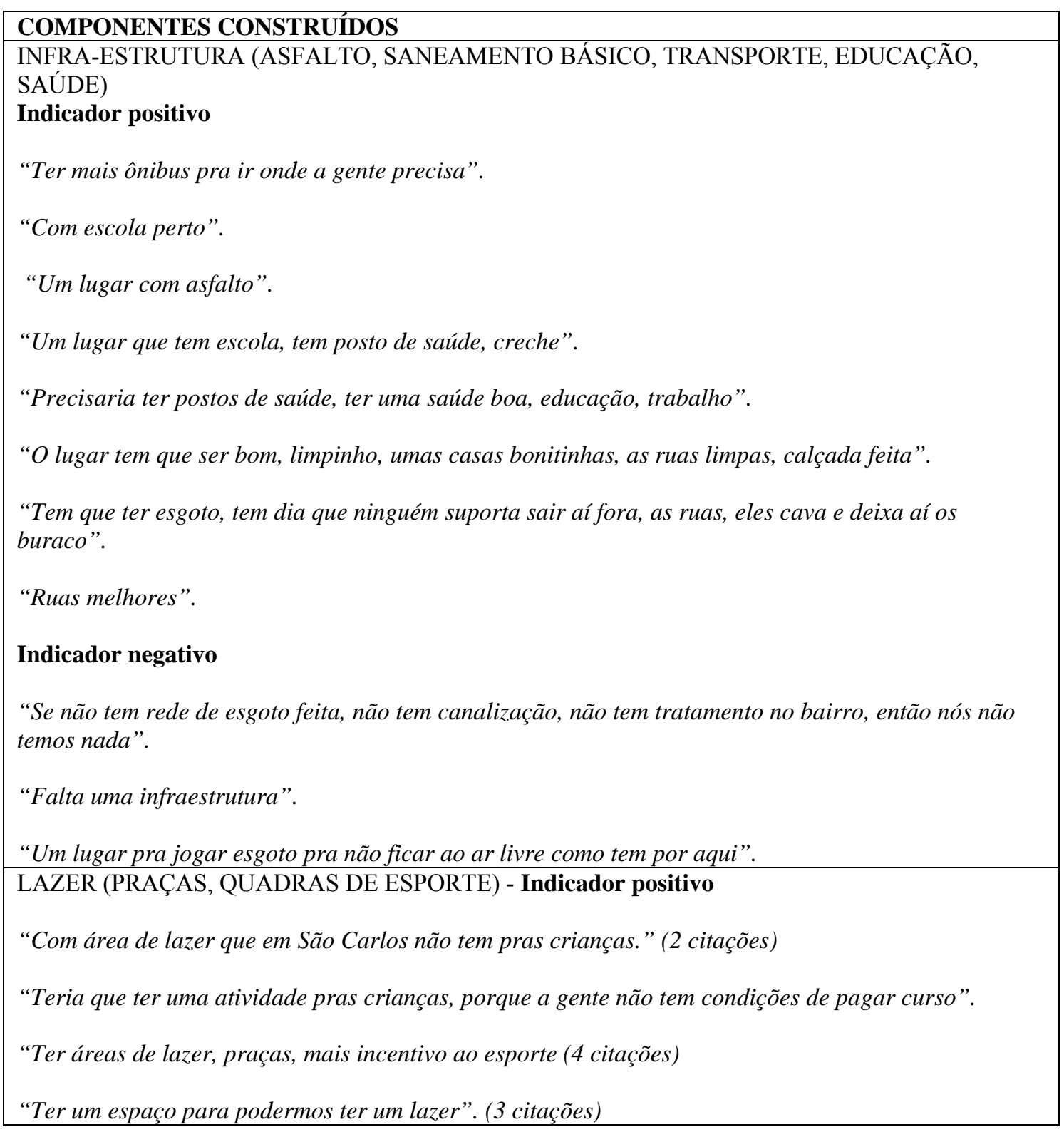


"Uma cidade com parques e áreas de lazer".

ORGANIZAÇÃO E LIMPEZA

Indicador positivo

“Ah, um lugar limpo, sem lixo, arejado”.

“Um bom lugar, naturalmente, limpeza que é uma coisa boa”.

“Um lugar com mais organização, com mais ordem, mais limpo”.

“A cidade limpa e bem organizada”. (3 citações)

indicador negativo

“Menos poluição”.

“Eu acho que cidade não é lugar de cavalo, de lixo, as casas são uma em cima da outra”.

“Todo lugar é bom pra viver, aqui falta organização, deixa o lixo na rua, esgoto, é muito mal organizado".

Quadro 7: Componentes construídos que influenciam na qualidade ambiental.

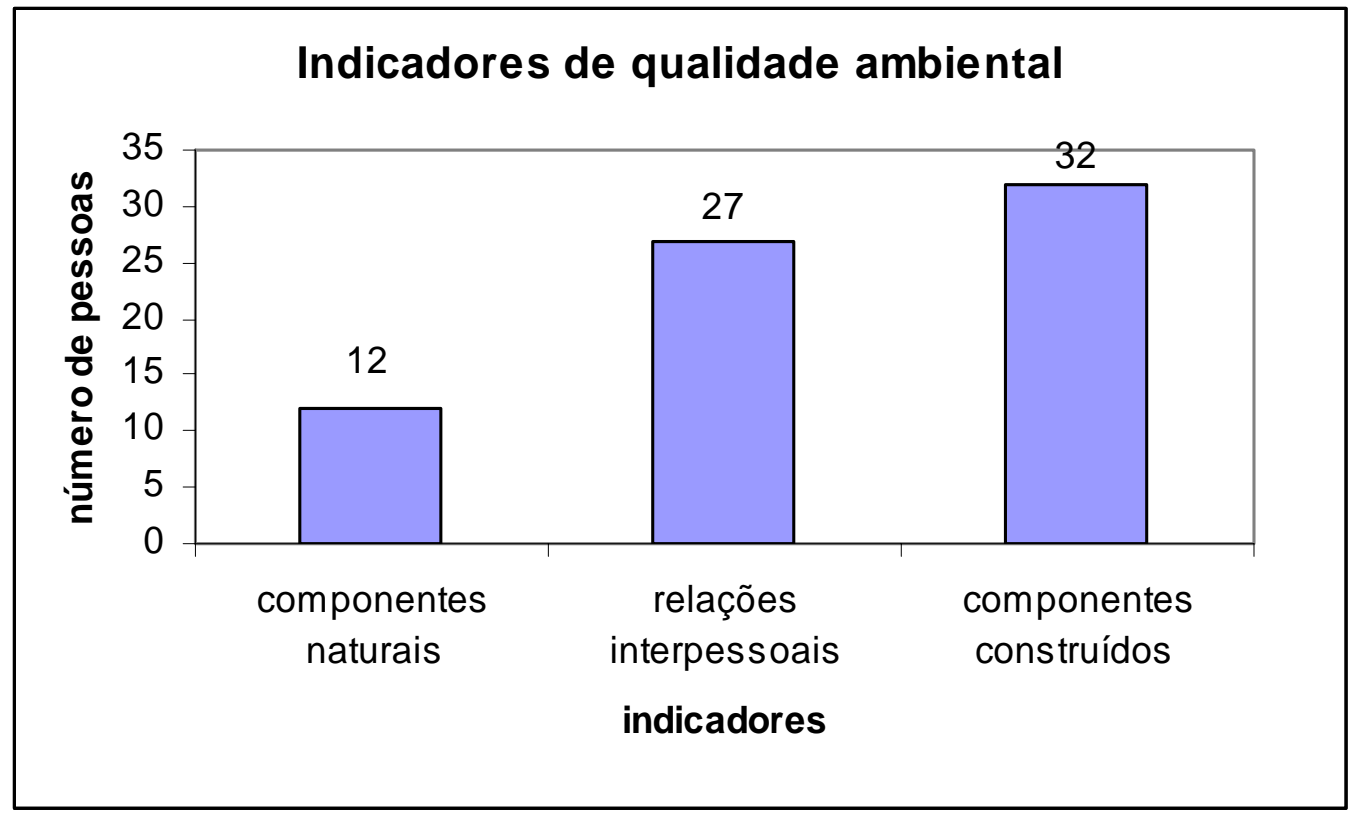

Figura 43: Indicadores de qualidade ambiental segundo a percepção da comunidade de quatro bairros da Microbacia do Córrego da Água Quente.

A partir dos quadros 5, 6 e 7 podemos concluir que todas as respostas para a questão 16 “como deve ser um bom lugar para se viver na cidade?” podem ser caracterizadas como antropocêntricas, uma vez que se basearam somente em um lugar adequado para a vida humana. A figura acima demonstra que, de acordo com a percepção da população entrevistada, um bom lugar para se viver é determinado predominantemente pelos componentes construídos de um ambiente (que aparecem em 
$80 \%$ das respostas) e pelas relações interpessoais estabelecidas neste espaço (que aparecem em 67,5\% das respostas), sendo estes os aspectos mais significativos para a determinação da qualidade ambiental. Os componentes naturais do ambiente, por sua vez, denotam pouca representatividade (30\% das respostas), embora essa população resida em local muito próximo a uma extensa área de vegetação natural, com funções ambientais que, direta ou indiretamente, influenciam a qualidade ambiental da microbacia. Essa percepção possivelmente corrobora com a realidade de grande parte das(os) residentes da microbacia, que não têm atendidas algumas necessidades humanas essenciais, como moradia em local com infra-estrutura urbana básica (saneamento básico, asfalto, coleta adequada de resíduos), atendimento médico de qualidade, transporte, emprego, entre outras.

Em estudos na cidade de São Paulo, Maricato (1996) e Jacobi (2000a) verificaram que a cartografia da exclusão ambiental, é a mesma da exclusão social, jurídica, educacional, profissional e cultural. A classe social que reside em áreas urbanas ambientalmente degradadas tem baixo poder aquisitivo, pouco acesso à educação e cultura, trabalha e habita informalmente, além de estar mais sujeita à violência. Esses locais são mais propícios a desmoronamentos, inundações, são fisicamente frágeis, onde há disposição inadequada de lixo e a fiscalização ambiental é precária, além da falta de infra-estrutura. Esses autores defendem a importância da expansão da infra-estrutura para a diminuição dos problemas ambientais, pois enquanto a infra-estrutura for concentrada, o mercado será especulativo e a exclusão consolidarse-á ainda mais.

Ainda em relação à questão "como deve ser um bom lugar para se viver na cidade?" analisamos o número de respostas nas quais as pessoas se referiram específica e explicitamente à área verde, podendo-se observar no quadro 8 que somente cinco pessoas $(12,5 \%)$ o fizeram, relacionando a existência desta à sua qualidade de vida, sendo que uma pessoa considera que a área oferece perigo devido à presença de animais peçonhentos (serpentes), uma pessoa relaciona a área verde com lugares do passado, demonstrando saudade, mas também demonstra medo dizendo que nunca adentrou na área. Três participantes, além de perceber a existência da área verde, deixam clara sua preferência pela recuperação e conservação (preservação da mata e recuperação da qualidade da água das nascentes através da canalização do esgoto). 
“...aqui pra esse lado tem muita cobra, dentro da casa da minha mãe foi pego três cobras, a última delas cataram, minha mãe dormindo 6 horas da manhã, meu pai chegou do serviço foi deitar, a cobra embaixo do travesseiro, uma coral. Uma irmã minha levantou a cobra passou em cima do pé dela, coral também, e a outra dentro do fogão do vizinho. (...) E nunca ninguém resolveu nada, devia ser muito estudado isso aí.”

“...um lugar pra jogar esgoto pra não ficar ao ar livre como tem por aqui.”

“(...)Aquela água mesmo (da área verde) é uma coisa que devia tratar, até pra servir o bairro inteiro. Então eu me preocupo mais com aquela água ali, que é uma água que desde criança a gente bebia ela, sem precisar ferver, sem precisar nada. Tem uma mina lá, ela é no barranco, ela solta aquela água e é térmica. É ali mesmo no Gonzaga, mas descendo o Buracão.(...)”

“(...)O que tem de mata tem que ser preservado. Senão não adianta nada, o que a gente vai fazer com tanta casa se não tem nenhum pouquinho de mata? Tem o mato, mas estão tirando o que tem. (...)”

“(...) Eu não entendo muitas coisas sobre mata, lá em Minas a gente andava bastante na mata, apanhava lenha, via os bichinhos, via tatu, via cobra, mas aqui eu nunca fui pra esse mato aí (aponta). Quer dizer, tem muitos passarinhos, muitos bichinhos assim, mas eu nunca fui lá não. Eu só vou no lixo ali na beiradinha e volto pra casa de novo".

Quadro 8: Respostas que explicitam a percepção da existência da área verde da Microbacia do Córrego da água quente e sua relação com a qualidade de vida das pessoas entrevistadas.

\section{QUESTÃo 17: Existe alguma relação entre um bom lugar para se viver na cidade e a existência de um local como a área verde próxima ao bairro?}

Antes de iniciar a questão 17, a entrevistadora perguntava qual o nome da área verde adjacente ao bairro da(o) entrevistada(o). Foi possível perceber que as denominações dadas à área verde variam de um bairro para o outro, possivelmente devido às diferentes localizações dos bairros em relação à área estudada. Para as populações do Jardim Gonzaga e do Monte Carlo, cujos bairros estão situados na porção mais elevada da microbacia, a área verde é conhecida como "buracão". E a maioria das(os) participantes do bairro Pacaembu a denominam "barroca", uma vez que também este bairro situa-se em uma região de maior altitude da microbacia em relação à área verde. As pessoas residentes no bairro Antenor Garcia chamam-na de "vale" e "morro", uma vez que esse bairro compõe o trecho de menor altitude da microbacia e a área verde é avistada na parte mais alta. Também apareceram os seguintes nomes: "mata, reserva da prefeitura, nativa e árvores nativas".

\footnotetext{
${ }^{1} \mathrm{O}$ termo área verde foi substituído em todas as questões seguintes por buracão, mata, reserva da prefeitura, vale, nativa, árvores nativas, barroca, morro, etc, de acordo com o nome pelo qual cada participante reconhece a área.
} 
Estudar qual a percepção da comunidade em relação à influência da área verde na qualidade ambiental do lugar onde vive e em sua qualidade de vida foi o objetivo da questão 17. A partir das respostas, foi possível analisar se, de acordo com a percepção da comunidade, a área verde influencia ou não na qualidade de vida (Tabela 1), que tipo de influência exerce (positiva ou negativa) e quais as características da área responsáveis por essa influência.

Tabela 1: Percepção das(os) entrevistadas(os) sobre a relação entre a sua qualidade de vida e a existência da área verde.

\begin{tabular}{|c|c|}
\hline \multicolumn{1}{|c|}{ Tipos de respostas } & Número de respostas \\
\hline SIM & 31 \\
\hline NÃO & 2 \\
\hline NÃO SEI & 2 \\
\hline $\begin{array}{l}\text { Respostas em desacordo com a pergunta (falou } \\
\text { sobre outra coisa) }\end{array}$ & 5 \\
\hline
\end{tabular}

A percepção de que a área verde influencia na qualidade de vida apareceu em $77,5 \%$, ou seja, uma fração significativa de pessoas percebe essa função ambiental desse ecossistema, mas algumas não souberam explicar por quê. A partir das respostas "sim" para a questão 17 que apontaram as características da área verde relacionadas com um bom lugar para se viver, foi possível identificar as características que têm influência positiva ou negativa, compondo as categorias presentes no quadro 9.

\footnotetext{
QUALIDADE DO AR

"Aqui, na parte de oxigênio, até agora eu não tenho do que reclamar sobre mal cheiro, essas coisas, porque não está tendo. Nesses cinco anos eu não tenho nada que reclamar”.

"Eu acho que o ar livre é bom, mesmo a gente não querendo, aqui tem um ar diferente do que o lá do centro".
}

\section{VEGETAÇÃO}

“Sim, tem uma grande área vegetativa , e uma área para prática de lazer”.

“Eu gosto de morar aqui por causa do verde”.

\section{PÁSSAROS}

"Pra mim não resta dúvida, só de eu levantar e olhar os passarinhos que vêm aqui, que cantam de madrugada, ouço seriema cantar, sabiá cantar aí no buracão na parte da tarde”.

"Eu tenho fruta no quintal e os passarinhos vêm comer. Pra mim é outra vida, já é uma grande coisa não morar na selva de pedra, eu considero que não moro numa selva de pedra. Influencia bastante, mas bastante mesmo".

PAISAGEM, QUE PROPORCIONA SAÚDE E BEM ESTAR (HIGIENE MENTAL, TRANQUILIDADE, SILÊNCIO E PAZ), ALÉM DA PREOCUPAÇÃO COM A DEGRADAÇÃO DA ÁREA VERDE 
“Tem. Porque muita gente às vezes fica neurótica morando no centro da cidade, as pessoas até entram em depressão por causa do barulho, do trânsito, então se todos os bairros tivessem uma pequena área verde assim seria melhor. Seria bem melhor, tirando a marginalidade. Agora aqui essa área verde não se pode chamar de área verde, porque aqui é apenas um buraco ali abandonado, tem esgoto que passa ali a céu aberto, não é bem assim natureza não. É que daqui parece bonito, mas vai lá embaixo, lá é feio".

“De minha preferência, eu nunca fui de sítio ou roça, mas eu gosto demais”.

“Aqui a gente pode ficar mais perto da natureza, né? Porque morar nos lugares que não tem uma natureza assim, não compensa. Agora aqui está quieto, mas tem hora que isso aqui fecha de molecada pra jogar bola, e você passa a hora aqui que você nem vê. Se vai morar lá no centro da cidade, o lazer é só pra quem tem mesmo, já é tudo mais paradão, né?”.

“Tem um pouco. Muita gente fala que o buracão é ruim, porque tem poluição, o rio aí é muito poluído e tudo, mas se for analisar bem, se eu sentar naquela pedra ali (com vista para a área verde) fico até bem, você viaja. É que está sol, mas quando é de tardezinha, de noite, você senta naquela pedra ali, noite de lua cheia assim, você viaja, você nem imagina, você não quer nem saber do resto. Isso é uma coisa que a gente nem fala, mas quando você está triste, se você morar numa fazenda assim, o melhor lugar pra você desabafar é embaixo de uma árvore, ficar sentado embaixo de uma árvore, você deita embaixo da árvore e relaxa. Aqui é a mesma coisa, quando não tem nada pra fazer a gente senta ali naquela pedra, fica ali olhando ali pra baixo. A única coisa é o rio que corta aí, sujo, mas o resto...”.

"Acho que a mata não tem nada a ver, o que manda é os moradores reservar ela. Tem que conservar ela pra ter um ar livre e a gente morar sossegado, porque aquela área não vai prejudicar morador nenhum de sobreviver num lugar. Ela vai trazer saúde e vai trazer coisas melhores para as crianças, o que manda é o tratamento, é a gente tratar dela, que ela está suja, então não tem como a gente apoderar daquela água do ambiente”.

\section{BELEZA DA PAISAGEM (COM ÊNFASE NA VEGETAÇÃO)}

"Tirando o esgoto que estão jogando nessa barroca, eu acho que não, porque tem uma vista bonita. Eu gosto, já desci lá pra baixo, meu irmão já pegou cobra, tem bicho lá, é gostoso, sabe? Pode ter uma influência boa se for mais cuidada, mais preservada”.

“Eu acho bonito. Essa área, eu concordo até com o prefeito. Qualquer prefeito que fizer uma área ambiental, eu sou a favor. Eu gosto muito da área, eu adoro. Onde eu nasci, eu nasci no meio de uma serrona. Minha esposa nasceu num lugar que tinha três bicos de serra junto, ela nasceu bem no buraco. E eu nasci num lugar de serra, só que era mais aplainado. Eu acho bonito, acho bonita a grota”.

“Não, a mata é boa, porque a gente não tem outro lugar pra olhar, olha pra ela e vê aquelas flor, tempo de florá fica bonito aí”.

"Se pudesse preservar aquela mata que tem ali beirando o rio, ficava bonito, porque já pensou uma árvore ali, um bairro sem árvore é muito ruim. Aqui no bairro Antenor Garcia a gente trata as árvores e todas as ruas têm. No Cidade Aracy, já não tem. Fica um bairro bonito. Eu acredito que uma área daquela (mata) deveria se cuidar melhor, pra dar uma visão melhor do bairro".

“Não, essa mata aí, ela não aborrece ninguém. Eu achava que devia cuidar dela melhor ainda, pra poder manter bonita como ela é, porque o verde é muito bonito assim pra gente sair, conhecer assim num dia bonito de sol, a gente ver esses pés de árvore verde é muito bonito, sentir o gostinho do mato, então eu gostaria que cuidasse melhor da mata”.

"Pra mim, faz 33 anos que eu estou aqui, já estou acostumada. Sempre é bom, né? Mata faz bem pra gente. O verde é bom, quando está seco fica feio. Quando está verde fica bonito”.

"Acho que tem que estar tudo junto, né? Porque aqui eu já acostumei, faz bastante tempo que eu moro aqui, já acostumei com essa mata... Claro que o povo está acabando, o pessoal taca fogo. Mas logo 
quando eu cheguei aqui, era muito verde, era lindo demais! Agora ainda está bonito, mas muita coisa mudou desde quando eu estou aqui".

\section{ÁREA VERDE AUMENTA A QUALIDADE AMBIENTAL DO ENTORNO}

"Eu acho que é por causa disso que aqui não tem tanta poluição. Se aqui tivesse mais casa, teria mais poluição. Mas isso aí vai ser construído, viu? Depois vai ter mais poluição”.

"Sim, se for cuidado como área verde pra fazer parte do bairro mesmo, fica muito bom e se torna um bom lugar de se morar".

\section{ÁREA VERDE QUE PODE SER TRANSFORMADA EM ÁREA DO BAIRRO OU ÁREA DE} LAZER

"Eu acho que tem, eu não sei se eles vão fazer mesmo, mas parece que essa mesma fábrica (empresa responsável pelas construções do Projeto de Urbanização Integrada dos bairros Jardim Gonzaga e Monte Carlo, financiado pelo BID) vai fazer uma área de lazer aí atrás, mas que jeito eu não sei, com esse buraco todo aí. Já teve uma época, há muito tempo atrás, eles traziam muita terra pra tentar fechar esse buraco, mas daí eles não conseguiram, porque tem água também aí embaixo. Se eles conseguirem mesmo fazer uma área de lazer, seria bom pra criançada que fica direto jogada na rua, porque as mães não olham direito. Daí seria uma área de lazer pra eles não ficar na rua, pra eles brincar. Um lugar que não passa carro, é bom assim”.

“Eu, na minha opinião, acho assim: Se esse buracão fosse tratado, ele ia ficar muito bonito, ia ser um bom lugar. Eu olho daqui, olho lá em baixo, eu falo ai meu Deus, se tampasse, canalizasse, podasse umas árvores, ia ficar um parque muito bonito, eu acho que seria um bom lugar”.

Quadro 9: Características da área verde, responsáveis por uma influência positiva na qualidade de vida.

De acordo com a percepção das(os) participantes, 50\% apontam características positivas. A principal característica da área verde, comentada por sete entrevistadas(os), que faz com que esta influencie positivamente no espaço onde vivem é a beleza da paisagem, principalmente no que diz respeito à vegetação, que remete ao passado, fazendo lembrar outras paisagens naturais belas, ou recordar o próprio local nos tempos em que a área verde era mais exuberante. Durante as entrevistas, diversas pessoas reportam-se aos seus lugares de origem, recordando paisagens e comparando-as com a área verde, o que mostra, de acordo com Tuan (1980), que as experiências do passado influenciam as relações com o lugar do presente. Aquelas pessoas que em tempos passados conviveram mais intimamente com ecossistemas naturais, tendem a apresentar uma relação de topofilia com a área verde e maior consciência da necessidade de recuperação.

A segunda característica positiva que mais aparece nas respostas é a relação da área verde com a saúde e o bem-estar da comunidade, podendo proporcionar maior higiene mental, tranqüilidade, silêncio e paz àquelas(es) que a contemplam ao longe ou a freqüentam. As mesmas pessoas que sentem esse bem-estar também demonstram 
preocupação com a degradação crescente da área, talvez por compreenderem que existe um risco iminente de perderem esse lugar agradável.

Entre as demais características apontadas, destacam-se a qualidade do ar, considerado melhor quando comparado ao ar do centro da cidade; a vegetação, uma vez que morar "perto do verde" é motivo de satisfação; os pássaros, que trazem alegria com suas vocalizações; e a importância da área para a redução da poluição da microbacia. Duas pessoas afirmam que a área verde pode ser interessante para o bairro, mas não como é atualmente, necessitando de algumas modificações para se tornar um parque ou área de lazer.

Entre as características negativas atribuídas à área (Quadro 10), destacam-se a má qualidade do ar, devido à poeira e à fumaça proveniente das queimadas, e ao mau cheiro que exala do esgoto e do lixo depositados no local. O perigo devido à declividade, à falta de manejo e à violência relacionada à área, é lembrado por $10 \%$ das pessoas. De um modo geral, a maioria das(os) participantes afirma que a influência da área verde é positiva, o que aumenta as chances de, através da implementação de projetos de EA com a comunidade da microbacia, estimular ainda mais o sentimento de topofilia já notado em boa parte da população local.

\section{QUALIDADE DO AR (MAU CHEIRO, POEIRA)}

"Não, de ruim tem a sujeira, o cheiro muito ruim que sobe por causa do esgoto. Às vezes as pessoas jogam animal morto, sobe aquele cheiro ruim".

"Eu acho legal porque é sempre gostoso estar em volta de área verde dá um clima diferente, um ar mais livre, mas quando é bem zelado, não tem o que acontece, por exemplo aqui pra gente é horrível, muita poeira, muita fumaça o dia inteiro, fica abafado, ataca a bronquite. Aqui tem a sucata atrás, eles queimam muito cobre, a fumaça do cobre é horrível. Tem muito lixo, muito rato”.

\section{PERIGO DEVIDO À DECLIVIDADE}

"Você sabe que as partes de baixo é sempre mais perigosa, especialmente quando chove. Aqui nunca aconteceu nada, apesar que essa rua aqui corre muita água.”

“É perigo por causa das crianças, se cair lá embaixo, Deus me livre, né?”

\section{PERIGO (VIOLÊNCIA)}

“Mas, com essa sujeira, não tem condições de melhorar, sabe? Do jeito que está entrar não pode, se entrar se perde, bandido, tudo que entra ali a polícia não pega”.

\section{ÁREA INACESSÍVEL}

"Do jeito que está aí eu acho que não porque pode trazer conseqüências ruins. Até pras crianças não é bom, ninguém usa, podia ser mais acessível, mais cuidado e fazer parte da comunidade, mas infelizmente..."

Quadro 10: Características da área verde responsáveis por uma influência negativa. 
Questão 18: O que você pensa sobre a existência da área verde próxima ao seu bairro? Por que?

O grau de satisfação por morar próximo à área verde foi obtido na questão 18 , cujas porcentagens de respostas estão na figura 44, podendo-se observar que a maioria das pessoas (57,5\%) mostra-se satisfeita, enquanto $25 \%$ afirmam ser "ruim ou péssimo", referindo-se principalmente ao atual estado de degradação e/ou abandono da área pelos órgãos responsáveis.

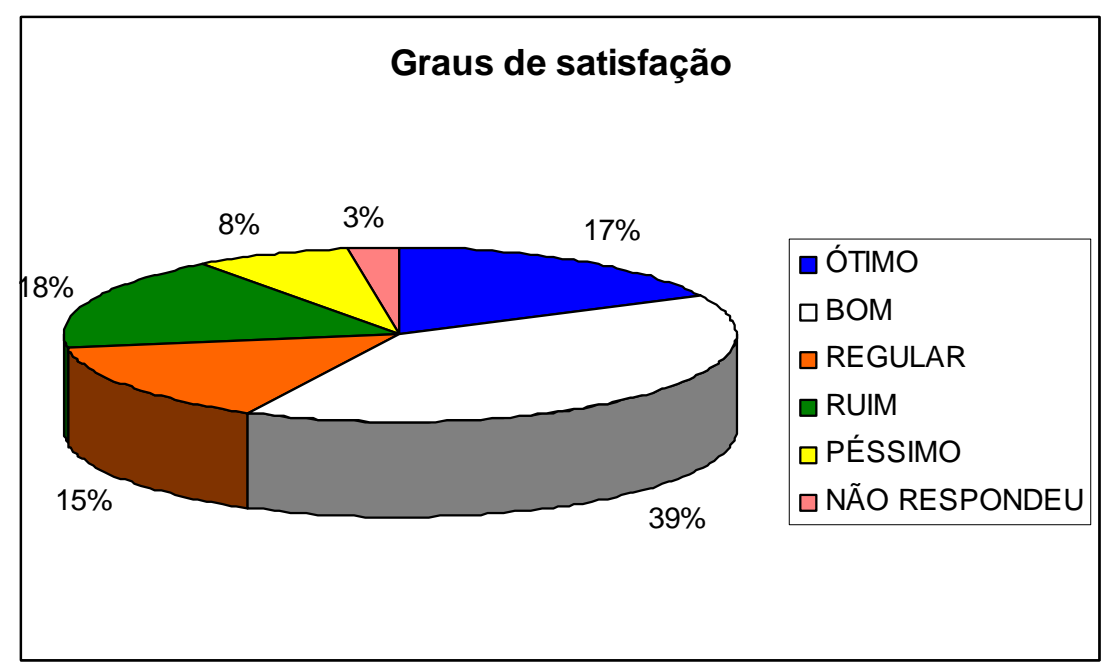

Figura 44: Grau de satisfação por morar próximo à área verde.

Na questão 18, além de perguntar o que a pessoa pensava da existência da área verde próximo ao seu bairro, pedimos que justificasse o por quê de sua resposta, que variou de "ótimo" a "péssimo", com o objetivo de investigar possíveis relações de topofilia ou topofobia com o local. A partir dessas justificativas, pudemos identificar as características naturais da área verde e as características conseqüentes da interferência antrópica que influenciaram ou definiram na/a percepção da comunidade em relação à área verde. Essas características foram agrupadas em positivas e negativas, e subdivididas nas categorias "componentes naturais" e "componentes de origem antrópica", conforme o quadro 11.

De acordo com a percepção das(os) entrevistadas(os) que denota topofilia, as características naturais positivas da área que aparecem são a boa qualidade do ar (15\% das respostas), a vegetação (12.5\%), a natureza de modo geral (10\%), a beleza da paisagem $(7,5 \%)$ e a importância da área para a conservação das fauna, citada por apenas uma pessoa. Quanto ao uso da área verde para fins humanos, uma pessoa 
percebe sua importância como área de lazer e uma pessoa afirma que a área traz benefícios à saúde. Para 10\% das(os) entrevistadas(os), o local remete a lembranças do passado, tempos de infância vividos ali mesmo ou lugares semelhantes que deixaram boas recordações.

Em relação à percepção negativa da área, que denota topofobia, predominaram os componentes não naturais (antropogênicos), como queimadas, presença de esgoto, poluição, falta de fiscalização e de conscientização da população, e os perigos ligados ao narcotráfico. Quanto às características naturais da área consideradas negativas, foram citados o perigo devido à declividade, à escuridão noturna e à presença de animais como cobras, aranhas, baratas e pernilongos. Em relação a essas espécies da fauna, Gonçalves (1989) faz uma reflexão interessante chegando à conclusão que são espécies culturalmente $^{2}$ repugnantes e geradoras de topofobia. Essa aversão cultural e transmitida entre as gerações muitas vezes oculta as causas da proliferação descontrolada de suas populações, que revelam práticas antrópicas inadequadas de disposição de resíduos sólidos e efluentes domiciliares e/ou de degradação de seus ecossistemas naturais, obrigando-as a ocupar a área urbanizada.

A partir desses resultados, pode-se perceber que somente uma pessoa possui uma visão biocêntrica em relação à área verde, quando se refere à importância desse ecossistema para a conservação das espécies animais. Por outro lado, as respostas dos demais apresentam uma posição antropocêntrica, ou seja, caracterizam a área verde somente a partir da influência desta sobre a vida humana.

Várias respostas a estas questões não foram incluídas no quadro 11, uma vez que $10 \%$ das pessoas afirmaram não saber justificar o porquê é positivo ou negativo residir próximo à área verde, e outros 17,5\% deram respostas relacionadas a outros fatores, como o bairro, a vizinhança, não se referindo à área verde.

\footnotetext{
${ }^{2}$ É relevante salientar que esta é uma concepção peculiar de nossa cultura ocidental e urbanizada, que difere da percepção de outros povos e culturas em relação a essas espécies animais. Tuan (1983) afirmou que "cada cultura possui seus próprios símbolos de intimidade, amplamente reconhecidos pelas pessoas".
} 


\begin{tabular}{|c|c|c|c|}
\hline \multicolumn{2}{|c|}{$\begin{array}{c}\text { CARACTERÍSTICAS POSITIVAS DA ÁREA } \\
\text { QUE LEVAM À TOPOFILIA }\end{array}$} & \multicolumn{2}{|c|}{$\begin{array}{l}\text { CARACTERÍSTICAS NEGATIVAS DA } \\
\text { ÁREA QUE LEVAM À TOPOFOBIA }\end{array}$} \\
\hline \multirow[t]{5}{*}{$\begin{array}{l}\text { COMPONENTES } \\
\text { NATURAIS }\end{array}$} & qualidade do ar & $\begin{array}{c}\text { COMPONENTES } \\
\text { NATURAIS }\end{array}$ & $\begin{array}{c}\text { perigo devido à } \\
\text { declividade }\end{array}$ \\
\hline & vegetação & & $\begin{array}{l}\text { perigo devido à } \\
\text { escuridão (noite) }\end{array}$ \\
\hline & beleza da paisagem & & \multirow[b]{3}{*}{$\begin{array}{l}\text { perigo devido à } \\
\text { presença de } \\
\text { animais) }\end{array}$} \\
\hline & $\begin{array}{c}\text { natureza (como um } \\
\text { todo) }\end{array}$ & & \\
\hline & $\begin{array}{c}\text { ecossistema } \\
\text { importante para a } \\
\text { conservação do } \\
\text { equilíbrio ecológico, } \\
\text { da fauna }\end{array}$ & & \\
\hline \multirow[t]{7}{*}{$\begin{array}{l}\text { COMPONENTES NÃO } \\
\text { NATURAIS }\end{array}$} & $\begin{array}{c}\text { lembrança do } \\
\text { passado }\end{array}$ & \multirow[t]{7}{*}{$\begin{array}{l}\text { COMPONENTES NÃO } \\
\text { NATURAIS }\end{array}$} & Queimadas \\
\hline & área para lazer & & $\begin{array}{c}\text { Esgoto a céu } \\
\text { aberto }\end{array}$ \\
\hline & \multirow[t]{5}{*}{ saúde e bem estar } & & Poluição (sujeira) \\
\hline & & & $\begin{array}{c}\text { Falta de } \\
\text { fiscalização }\end{array}$ \\
\hline & & & $\begin{array}{c}\text { Falta de } \\
\text { conscientização }\end{array}$ \\
\hline & & & $\begin{array}{c}\text { Falta de } \\
\text { loteamento (casas) }\end{array}$ \\
\hline & & & $\begin{array}{c}\text { Esconderijo para } \\
\text { drogas }\end{array}$ \\
\hline
\end{tabular}

Quadro 11: Características da área verde que contribuem para a topofilia (ou topofobia).

Questão 19: Existe alguma relação entre a saúde das pessoas do seu bairro e a existência da área verde próxima ao seu bairro? Qual?

Entre as questões sobre a influência da área verde na qualidade de vida da comunidade, foi perguntado sobre a relação entre a área verde e a saúde da população local (Figura 45 e Quadro 12). Para 67\% das(os) entrevistadas(os), existe uma influência da área verde sobre a saúde, sendo que praticamente a metade afirma que esta influência é positiva. Por outro lado, 23\% afirmam que não há relação com a saúde e $10 \%$ não souberam responder.

A partir da percepção das pessoas que acreditam que a influência é positiva, a característica da área verde favorável à saúde humana que mais se destaca é a contribuição para a boa qualidade do ar, citada por 6 pessoas. Também apareceram como vantagens à saúde a existência de plantas medicinais, de água e de sombra, proporcionando bem estar às(aos) freqüentadoras(es) e um lugar agradável para as crianças brincarem.

Dentre os componentes naturais da área que prejudicam a saúde, foi predominantemente citado o risco oferecido pela presença de animais, reconhecidos por 
13 respondentes como peçonhentos ou como vetores de doenças. Nesse sentido, destacou-se o perigo oferecido pelo mosquito da dengue, cujo controle, de acordo com as entrevistas, não é efetuado na área verde, apesar de esta apresentar inúmeros possíveis criadouros desse mosquito. As mesmas pessoas também percebem que várias características prejudiciais são conseqüência da interferência antrópica inadequada na área verde, e apontam como problemas para a saúde o esgoto a céu aberto, a presença de lixo, o mau cheiro proveniente esgoto e do lixo (que atinge os bairros principalmente em dias quentes), as queimadas (principalmente pela emissão da fumaça que provoca problemas respiratórios) e a falta de vegetação. Consideramos como um aspecto positivo essa percepção pela comunidade de que a maioria das características negativas atribuídas à área verde estão relacionadas às formas de utilização pelo ser humano, o que pode constituir o início de uma reflexão sobre usos mais sustentáveis para aquele ambiente e como isso reflete sobre a qualidade de vida da população local.

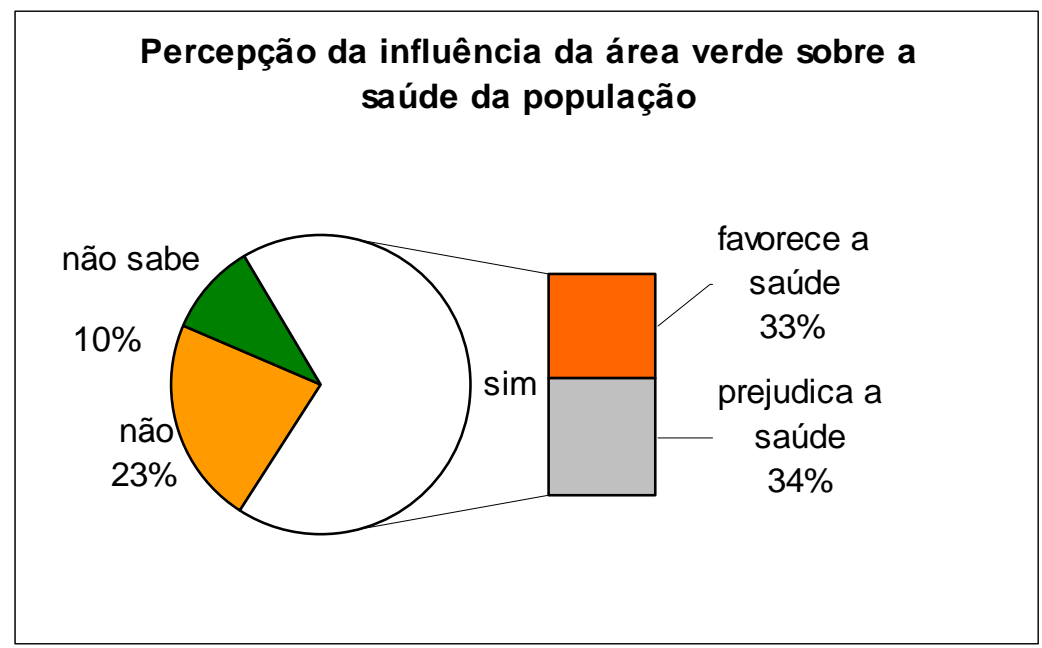

Figura 45: Percepção da influência da área verde sobre a saúde da população.

\begin{tabular}{|c|c|c|c|}
\hline \multicolumn{2}{|c|}{$\begin{array}{l}\text { CARACTERÍSTICAS QUE } \\
\text { FAVORECEM A SAÚDE }\end{array}$} & \multicolumn{2}{|c|}{$\begin{array}{l}\text { CARACTERÍSTICAS QUE } \\
\text { PREJUDICAM A SAÚDE } \\
\end{array}$} \\
\hline \multirow{3}{*}{$\begin{array}{l}\text { COMPONENTES } \\
\text { NATURAIS }\end{array}$} & Qualidade do ar & \multirow{3}{*}{$\begin{array}{l}\text { COMPONENTES } \\
\text { NATURAIS }\end{array}$} & Pernilongo, dengue \\
\hline & $\frac{\text { Plantas medicinais }}{\text { Á }}$ & & $\begin{array}{l}\text { Animais (bichos, } \\
\text { aranha, cobra, } \\
\text { escorpião) }\end{array}$ \\
\hline & Sombra & & Doenças dos animais \\
\hline \multirow{6}{*}{$\begin{array}{l}\text { INFLUÊNCIA DA } \\
\text { ÁREA VERDE } \\
\text { PARA O SER } \\
\text { HUMANO }\end{array}$} & $\begin{array}{l}\text { Saúde mental } \\
\text { (bem estar) }\end{array}$ & \multirow{6}{*}{$\begin{array}{c}\text { COMPONENTES NÃO } \\
\text { NATURAIS } \\
\text { (ANTROPOGÊNICOS, } \\
\text { ANTRÓPICOS) }\end{array}$} & Esgoto a céu aberto \\
\hline & \multirow{5}{*}{ Lugar para brincar } & & \\
\hline & & & Mau cheiro \\
\hline & & & $\begin{array}{l}\text { Queimadas (fogo, } \\
\text { fumaça }\end{array}$ \\
\hline & & & Desmatamento \\
\hline & & & Lixo \\
\hline
\end{tabular}

Quadro 12: Percepção em relação à influência da área verde sobre a saúde da comunidade. 
Questão 20: Você já foi até a área verde? Há quanto tempo faz isso e com que freqüência?

Em relação à questão 20 (Figura 46), a grande maioria (80\%) afirmou que já esteve na área verde. Dessas 32 pessoas que já visitaram, 18 são mulheres e 14 são homens. Porém, dentre os $20 \%$ que nunca visitaram a área ( 8 pessoas), 7 são mulheres, e estas demonstram em suas respostas um sentimento de topofobia em relação ao local, principalmente por medo de cair, associado à declividade e às valas resultantes da erosão.
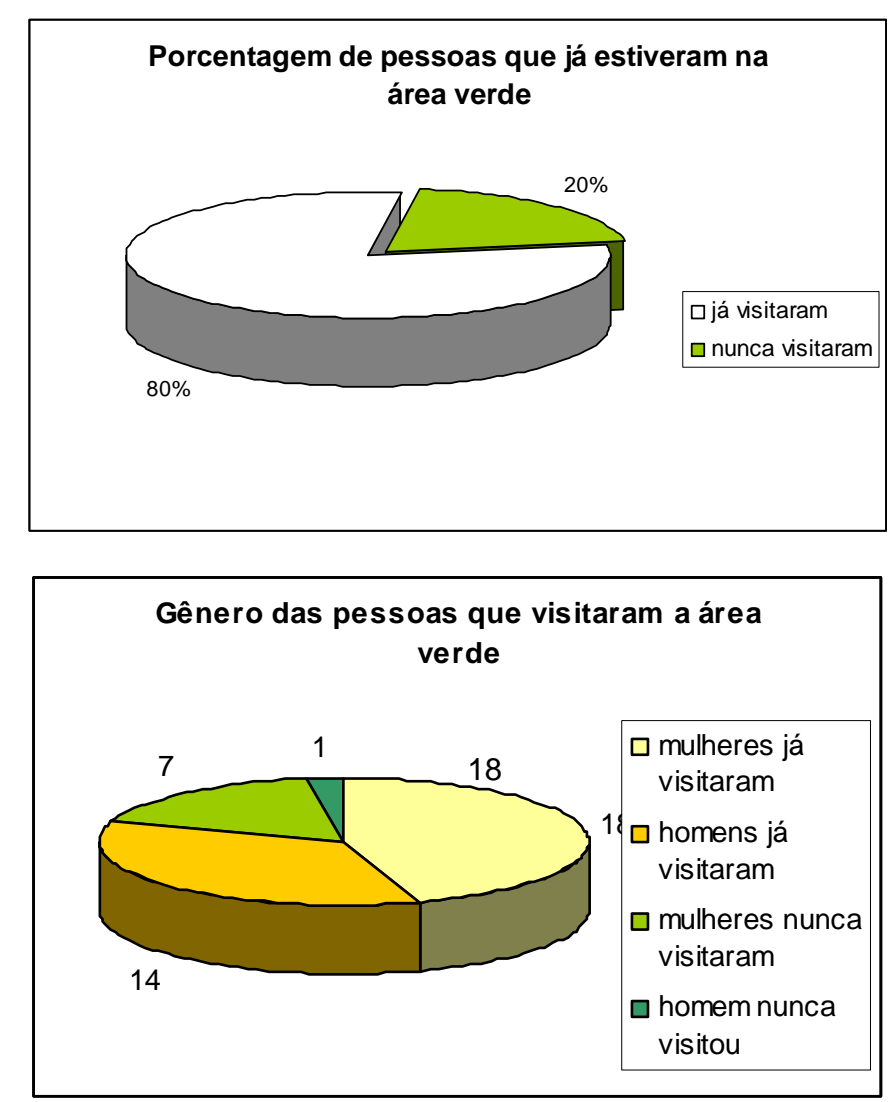

Figura 46: Relação entre gênero e o número de pessoas que já estiveram na área verde. 


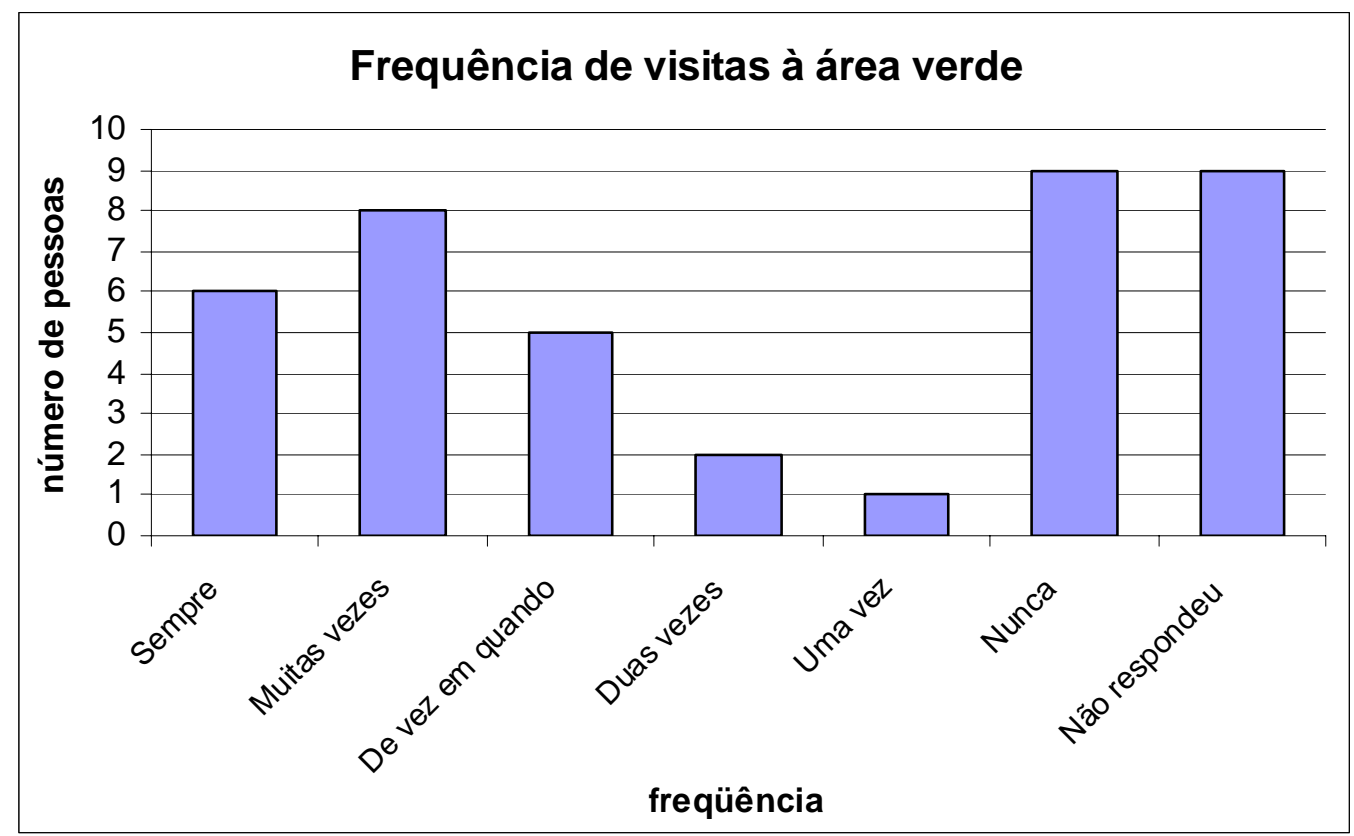

Figura 47: Freqüência de visitas à área verde.

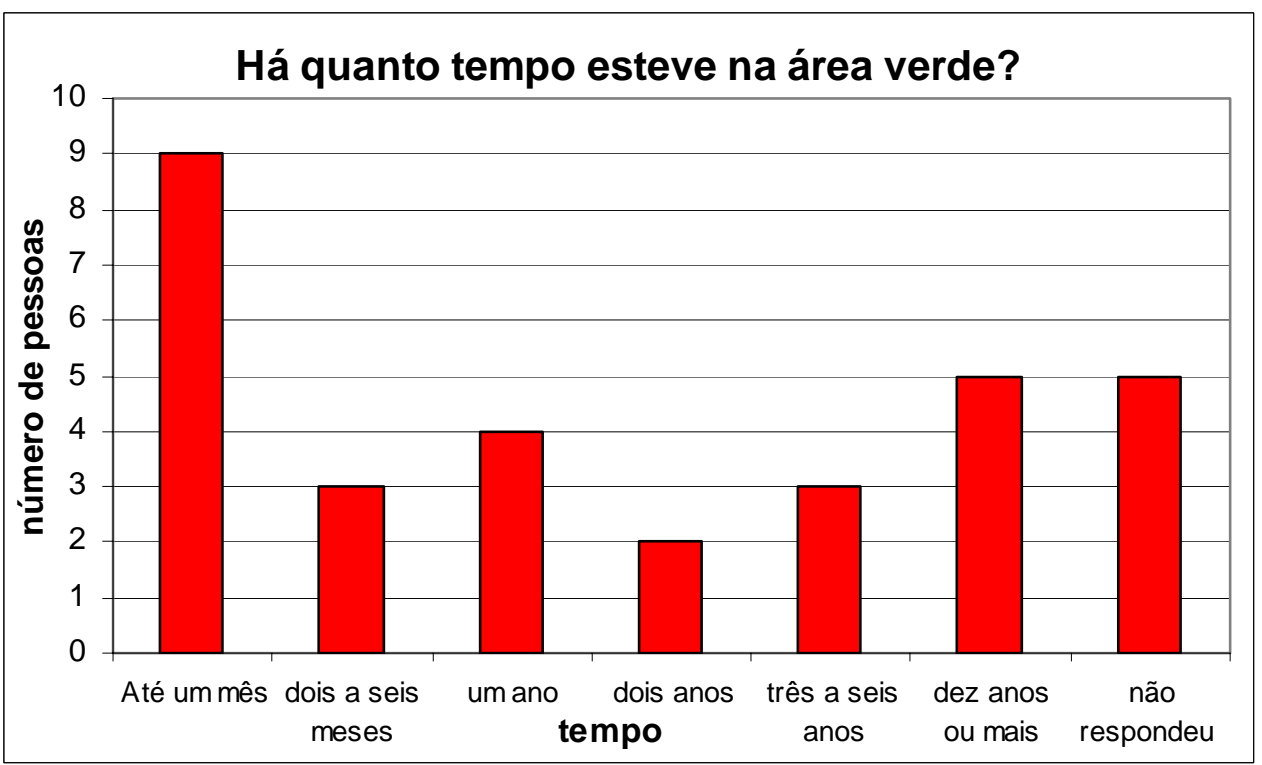

Figura 48: Período após a última visita à área verde.

De acordo com as Figuras 47 e 48, 35\% das(os) entrevistadas(os) visitam ou visitaram a área verde com bastante freqüência, tendo respondido "sempre" ou "muitas vezes" para esta questão, enquanto $22,5 \%$ nunca foram à área, embora residam em local praticamente adjacente à mesma. Ao perguntar há quanto tempo as(os) freqüentadoras(es) estiveram no local, a maioria contou que visitou a área há menos de um ano, o que significa que sua percepção baseia-se, além de possíveis lembranças do passado, também na situação ambiental atual da área verde. 
Também analisamos que tipo de relação cada pessoa estabelece com a área verde e quais os sentimentos em relação a ela (topofilia ou topofobia), a partir das respostas como as exemplificadas no quadro 13.

\author{
TOPOFILIA \\ LEMBRANÇA DO PASSADO \\ "Eu andava direto aí com meu moleque. Já faz bastante tempo, mas a molecada descia todo dia”. \\ "De vez em quando a gente ia brincar na água, eu, minha mulher, naqueles tempos..." \\ "Já desci muitas vezes e de vez em quando ainda desço no buracão. Desço no buracão desde \\ pequenininho, e até os 18 anos descia muito. De vez em quando meu moleque desce lá e quando a gente \\ vai ver, já está lá embaixo. Aí a gente fica na pedra chamando e ele vem subindo. Principalmente na \\ época de pipa a molecada desce aí".
}

\title{
AFETIVIDADE E PREOCUPACAO COM A QUALIDADE AMBIENTAL DA ÁREA VERDE
}

"Ah, já, descemos no rio lá embaixo. Bastante vezes eu fui lá. Só que agora está muito poluído o rio, uma judiação. Já faz tempo que eu desci, depois que desceram a rede de esgoto, eu não desci mais lá. Faz mais de 10 anos que eu não desço bem lá embaixo, no rio lá. É meu marido mais que vai pra lá, ele fala que o rio está tudo poluído".

"Eu estou acostumada, quando eu vou lá eu choro. Porque era limpa e agora está suja. Eu desço sempre, olhando a mata aí".

\section{TOPOFOBIA}

“Nunca desci no buracão. É muito perigoso”.

"Não, não tenho coragem, que é muito cheia de buraco, é muito cheia de coisa e eu tenho medo de às vezes escorregar. (Os filhos já foram?) Não, meus filhos não importam de ir não”.

"Lá pra baixo tem um buracão que não tem nem jeito. Dá medo, é uma valeta mais alta que esse poste aí”.

"Nunca fui na mata, e não deixo as crianças irem lá. O povo joga cachorro morto, fede, prejudica a gente. Uma vez jogaram um cavalo morto aí, quando o cavalo estava perto de explodir eles jogaram fogo no cavalo, aqui ficou um cheiro insuportável, a gente não tinha nem vontade de comer mais".

Quadro 13: Respostas que demonstram sentimento de topofilia e topobia pela área verde.

Dentre as respostas que demonstram topofilia pela área verde, destacam-se a relação desta com recordações agradáveis e a preocupação com a degradação da vegetação e do córrego. A nostalgia em relação ao ambiente da infância e juventude vivida ali mesmo na área verde ou em outros ambientes naturais semelhantes presente nas respostas e atrelada à topofilia também foi observada por Marin (2003) junto às(aos) moradoras(es) de Jardim, MS. 
O sentimento de topofobia ocorre quando a área verde é associada a vários tipos de perigo, devido à declividade das encostas, perigo de escorregar, presença de buracos e de animais mortos, o que provoca mau cheiro.

Também foi possível identificar os principais tipos de usos da área pelas(os) freqüentadoras(es), conforme as respostas descritas no Quadro 14, a qual serve para a travessia de um bairro a outro, para passeio, prática de esportes (corrida), pastagem de animais domésticos e até mesmo para caça. No passado, algumas pessoas usavam esse local para lavar roupas. Esse tipos de relação com a área expressam um caráter utilitarista e, segundo Meinig (1979) citado por Cabral e Buss (2001), esses usuários consideram essa paisagem como um lugar com valor associado à satisfação de necessidades. Por outro lado, tais usos também revelam um sentimento de pertencimento em relação à área verde que podem motivar a participação em projetos de recuperação.

TRAVESSIA ENTRE OS BAIRROS
“Ah, aqui é tudo cheio de trilho aí dentro. Faz mais de ano que eu não vou, mas eu ia bastante no
posto de saúde da Redenção, mas é legal, lá de dentro olhando de lá pra cá você tem uma visão tão
gostosa, lá você avista longe”.
“Já, já passei muitas vezes por aí. Já faz muito tempo que eu não passo, porque quando a gente passa
construindo aqui, o caminho era aí (na mata) pra gente chegar até no topo (no Medeiros), pra gente
pegar o ônibus”.
"Dá acesso ao Antenor, Gonzaga, Botafogo e Cidade Aracy”.
LAZER
"Sim, às vezes vou passear no vale ou fazer corrida”.
PASTAGEM DE ANIMAIS DOMÉSTICOS (GADO)
"Vou sempre, eu ando aquilo tudo ali, tem gente direto ali, as pessoas que criam animais, pra não
deixar solto na rua, deixam ali”.
USO DA ÁGUA (LAVAR ROUPA NO LOCAL, LEVAR ÁGUA PARA CASA)
“Já fui muitas vezes, a gente ia lavar roupa lá embaixo”.
“Já, mas faz tempo que eu não vou, mais ou menos um ano, mas eu já desci, andei tudo por ali,
atravessei da banda de lá, a gente desceu e já busquei água ali embaixo”.
CAÇA
uma pedrada ali, já tem um ali, pega na cabeça de um”.
Ouar

Quadro 14: Tipos de usos da área verde da MCAQ pela comunidade local. 


\section{Questão 21: O que você encontrou na área verde?}

O conhecimento da comunidade local em relação aos elementos abióticos e à biodiversidade presente na área verde é um importante passo para, através da Educação Ambiental, estimular a compreensão da necessidade de cuidado e proteção para com esse ecossistema, visando garantir a conservação da paisagem e da vida de várias espécies, algumas inclusive ameaçadas de extinção. Nesse sentido, procuramos investigar o conhecimento prévio da comunidade principalmente em relação à presença de corpos d'água e às espécies existentes na área estudada, além dos impactos ambientais mais evidentes. Para tanto, foram identificados nas respostas elementos pertencentes às seguintes categorias: BIODIVERSIDADE (Fauna e Vegetação), ÁGUA, PAISAGEM e IMPACTOS AMBIENTAIS. Somente cinco pessoas afirmaram não saber o que existe na área verde, e suas respostas não foram incluídas nas interpretações a seguir.

Ao investigar o conhecimento de algumas pessoas de Jardim (Mato Grosso do Sul) sobre a fauna e flora local, Marin (2003) percebeu que esse conhecimento foi construído a partir do contato direto das pessoas com as espécies animais e vegetais, e destacou a capacidade de observação e o interesse pela avifauna e o conhecimento em relação às espécies vegetais com propriedades medicinais.

\section{FAUNA}

Como o principal objetivo desses levantamentos é criar subsídios para o desenvolvimento de projetos de EA, priorizamos o levantamento da avifauna, por entender que há várias espécies adequadas à aplicação da técnica da espécie-bandeira (DIETZ e NAGAGATA, 1997), bastante interessante na etapa de sensibilização em relação à importância da conservação de áreas naturais.

No quadro 15, comparamos as espécies de aves citadas nas entrevistas e as encontradas na área verde durante os levantamentos. 


\begin{tabular}{|c|c|c|}
\hline Ordem/Família/Espécie & $\begin{array}{l}\text { Nome popular } \\
\text { (levantamento) }\end{array}$ & $\begin{array}{l}\text { Nome popular (percepção } \\
\text { da comunidade) e número } \\
\text { de citações }\end{array}$ \\
\hline \multicolumn{3}{|l|}{ CHARADRIIFORMES } \\
\hline \multicolumn{3}{|l|}{ Charadriidae } \\
\hline Vanellus chilensis & Quero-quero & \\
\hline \multicolumn{3}{|l|}{ CICONIIFORMES } \\
\hline \multicolumn{3}{|l|}{ Ardeidae } \\
\hline Egretta tula & Garça-branca-pequena & \\
\hline Casmerodius albus & Garça-grande & \\
\hline \multicolumn{3}{|l|}{ Cathartidae } \\
\hline Coragyps atratus & Urubu-de-cabeça-preta & \\
\hline \multicolumn{3}{|l|}{ COLUMBIFORMES } \\
\hline \multicolumn{3}{|l|}{ Columbidae } \\
\hline \multirow[t]{3}{*}{ Columba livia domestica } & Pombo doméstico & \multirow{3}{*}{$\begin{array}{l}\text { Pombinha } 2 \\
\text { Pomba-branca } \\
\text { Pomba-grande }\end{array}$} \\
\hline & & \\
\hline & & \\
\hline Columba picazuro & Asa-branca & \\
\hline Leptotila rufaxilla & Juriti-gemedeira, gemedeira & Juriti \\
\hline Columbina talpacoti & Rolinha-caldo-de-feijão & \\
\hline \multirow{3}{*}{ Scardafella squammata } & Rolinha-fogo-apagou & Rolinha-fogo-apagou \\
\hline & Rolinha-pequena-doméstica & \\
\hline & & Rolinha 2 \\
\hline \multicolumn{3}{|l|}{ CUCULIFORMES } \\
\hline \multicolumn{3}{|l|}{ Cuculidae } \\
\hline Crotophaga ani & Anu-preto & \\
\hline Guira guira & Anu-branco & \\
\hline Tapera naevia & Saci-do-campo & \\
\hline \multicolumn{3}{|l|}{ PASSERIFORMES } \\
\hline \multicolumn{3}{|l|}{ Furnariidae } \\
\hline Furnarius rufus & João-de-barro & \\
\hline \multicolumn{3}{|l|}{ Tyrannidae } \\
\hline Pitangus sulphuratus & Bem-te-vi & Bem-te-vi 4 \\
\hline Tyrannus melancholicus & Suiriri, siriri & \\
\hline Arundinicola leucocephala & Viuvinha & \\
\hline \multicolumn{3}{|l|}{ Pipridae } \\
\hline Antilophia galeata & Soldadinho & \\
\hline \multicolumn{3}{|l|}{ Mimidae } \\
\hline Mimus saturninus & Sabiá-do-campo & \multirow{3}{*}{$\begin{array}{l}\text { Sabiá } 4 \\
\text { Tejo }\end{array}$} \\
\hline Muscicapidae & & \\
\hline Turdus leucomelas & Sabiá-branco & \\
\hline \multicolumn{3}{|l|}{ Hirundinidae } \\
\hline Notiochelidon cyanoleuca & Andorinha-pequena-de-casa & \\
\hline Stelgidopteryx ruficollis & Andorinha-serradora-do-sul & \\
\hline \multicolumn{3}{|l|}{ Troglodytidae } \\
\hline \multirow{2}{*}{ Troglodytes aedon } & Corruíra & \\
\hline & Corruíra-do-campo & \\
\hline Coereba flaveola & Cambacica & \\
\hline Thraupis sayaca & Sanhaço-(cinzento) & \\
\hline Tangara cayana & Saíra-amarela & \\
\hline Fringillidae & & \\
\hline Sporophila leucoptera & Patativa & \\
\hline Sporophila caerulescens & Coleirinha & Coleirinha 5 \\
\hline Paroaria coronata & & Cardeal \\
\hline $\begin{array}{l}\text { Spinus magellanicus } \\
\text { (Carduelis magellanicus) }\end{array}$ & & Pintassilgo \\
\hline
\end{tabular}




\begin{tabular}{|c|c|c|}
\hline \multicolumn{3}{|c|}{$\begin{array}{l}\text { Quadro 15: Comparação entre os levantamentos in loco e a percepção da comunidade em relação } \\
\text { à avifauna da Microbacia do Córrego da Água Quente (continuação). }\end{array}$} \\
\hline Ordem/Família/Espécie & Nome popular (levantamento) & $\begin{array}{l}\text { Nome popular (percepção da } \\
\text { comunidade) e número de } \\
\text { citações }\end{array}$ \\
\hline & & Canário 2 \\
\hline & & Canário-do-reino \\
\hline & & Canário-persa \\
\hline Sicalis flaveola & Canário-da-terra & Canário-da-terra \\
\hline \multicolumn{3}{|l|}{ Emberizidae } \\
\hline Euphonia chlorotica & Vi-vi & \\
\hline Tangara cayana & Saíra-cabocla & \\
\hline Paroaria coronata & & Cardeal \\
\hline Sporophila caerulescens & & Papa-capim \\
\hline Zonotrichia capensis & Tico-tico-(do café) & Tico-tico \\
\hline Coryphospingus cucullatus & Tico-tico-rei-vermelho & Tico-tico-rei \\
\hline Volatinia jacarina & Tiziu & Tiziu (amarelinho) \\
\hline $\begin{array}{l}\text { Passerina brissoni } \\
\text { (=Cyanocompsa cyanea) }\end{array}$ & Azulão-verdadeiro & Azulão 2 \\
\hline \multicolumn{3}{|l|}{ Icteridae } \\
\hline Molothrus banariensis & Chupim & \\
\hline Gnorimopsar chopi & Pássaro-preto & Pássaro-preto 2 \\
\hline \multicolumn{3}{|l|}{ Formicariidae } \\
\hline Thamnophilus doliatus & Choca-barrada & \\
\hline Thamnophilus punctatus & Choca-bate-rabo & \\
\hline \multicolumn{3}{|l|}{ Corvidae } \\
\hline Cyanocorax cristatellus & Gralha-do-cerrado & Gralha 3 \\
\hline \multicolumn{3}{|l|}{ Ploceidade } \\
\hline Passer domesticus & Pardal-doméstico & Pardal 6 \\
\hline \multicolumn{3}{|l|}{ PICIFORMES } \\
\hline \multicolumn{3}{|l|}{ Picidae } \\
\hline Colaptes campestris & Pica-pau-do-campo & \\
\hline Campephilus melanoleucos & Pica-pau-de-topete-vermelho & \\
\hline Picamnus cirratus & Pica-pau-barrado-anão & \\
\hline Celeus flavescens & Pica-pau-amarelo & \\
\hline \multicolumn{3}{|l|}{ Ramphastidae } \\
\hline Ramphastos toco & Tucanuçu & \\
\hline \multicolumn{3}{|l|}{ PSITTACIFORMES } \\
\hline \multicolumn{3}{|l|}{ Psittacidae } \\
\hline Pionus maximiliani & Maitaca-verde & Maritaca 4 \\
\hline \multirow[t]{2}{*}{ Amazona aestiva } & Papagaio-curau & Papagaio \\
\hline & Periquito-de-encontro-vermelho & \multirow[t]{2}{*}{ Periquito 3} \\
\hline Brotogeris chiriri & Periquito-de-encontro-amarelo & \\
\hline \multicolumn{3}{|l|}{ TROCHILIFORMES } \\
\hline \multicolumn{3}{|l|}{ Trochilidae } \\
\hline Eupetomena macroura & Beija-flor-tesoura & \multirow[t]{3}{*}{ Beija-flor 2} \\
\hline Colibri serrirostris & Beija-flor-de-orelha-violeta & \\
\hline Phaethornis pretrei & Rabo-branco-acanelado & \\
\hline \multicolumn{3}{|l|}{ STRIGIFORMES } \\
\hline \multicolumn{3}{|l|}{ Strigidae } \\
\hline Speotyto cunicularia & Coruja-buraqueira & \\
\hline \multicolumn{3}{|l|}{ GRUIFORMES } \\
\hline \multicolumn{3}{|l|}{ Rallidae } \\
\hline \multirow[t]{2}{*}{ Aramides cajanea } & Saracura-três-potes & Três-potes \\
\hline & & Saracura \\
\hline Gallinula chloropus & Galinha-d'água & Galinha-d'água \\
\hline Cariamidae & & \\
\hline Cariama cristata & Seriema-de-pé-vermelho & Seriema 2 \\
\hline
\end{tabular}




\begin{tabular}{|c|c|c|}
\hline $\begin{array}{l}\text { Quadro 15: Comparação } \\
\text { à avifauna da Microbacia }\end{array}$ & $\begin{array}{l}\text { os levantamentos in loco e a perc } \\
\text { frrego da Água Quente (continua }\end{array}$ & $\begin{array}{l}\text { pção da comunidade em relação } \\
\text { ção). }\end{array}$ \\
\hline Ordem/Família/Espécie & Nome popular (levantamento) & $\begin{array}{l}\text { Nome popular (percepção da } \\
\text { comunidade) e número de } \\
\text { citações }\end{array}$ \\
\hline GALLIFORMES & & \\
\hline Cracidae & & \\
\hline Penelope superciliaris & Jacupeba & \\
\hline FALCONIFORMES & & \\
\hline Falconidae & & \\
\hline Polyborus plancus & Caracará-comum & Gaviãozinho-chama-chuva \\
\hline Milvago chimachima & Carrapateiro & \\
\hline ANSERIFORMES & & \\
\hline Anatidae & & \\
\hline Dendrocygna viduata & Irerê & \\
\hline TINAMIFORMES & & \\
\hline Tinamidae & & \\
\hline Crypturellus parvirostris & Inhambu-chororó & Inhambu \\
\hline ANSERIFORMES & & \\
\hline Anatidae & & \\
\hline Dendrocygna viduata & Irerê & \\
\hline PELECANIFORMES & & \\
\hline Phalacrocoracidae & & \\
\hline Phalacrocorax brasilianus & Biguá-una & \\
\hline Obs: A classificação das esp & abaixo não foi encontrada na litera & ura. \\
\hline & Paturi & Paturi \\
\hline & & Passarinho 3 \\
\hline
\end{tabular}

Quadro 15: Comparação entre os levantamentos in loco e a percepção da comunidade em relação à avifauna da Microbacia do Córrego da Água Quente.

Em relação à avifauna, apareceram nas respostas 35 diferentes nomes, sendo que alguns deles foram agrupados porque possivelmente representam a mesma espécie, resultando 31 espécies. No levantamento preliminar realizado ao longo do Córrego da Água Quente foi possível identificar 64 espécies de aves.

No quadro 16 encontram-se as demais espécies animais que apareceram nas entrevistas, e sua classificação e nomes populares de acordo com a literatura.

\begin{tabular}{|l|l|l|}
\hline \multicolumn{1}{|c|}{ Ordem/Família/Espécie } & $\begin{array}{l}\text { Nome popular (levantamento } \\
\text { bibliográfico) }\end{array}$ & $\begin{array}{l}\text { Nome popular (percepção da } \\
\text { comunidade) e número de } \\
\text { citações }\end{array}$ \\
\hline ARTRÓPODES & Insetos 2 \\
\hline CLASSE HEXAPODA (INSETOS) & \\
\hline Ordem Diptera & \multicolumn{2}{|l|}{} \\
\hline Musca domestica & Mosca doméstica & Mosquito 2 \\
\hline & Mosca varejeira & Mosquito verde de esgoto \\
\hline Aedes aegypti & Mosquito-da-dengue & Mosquito-da-dengue \\
\hline & & Pernilongo 6 \\
\hline \multicolumn{2}{|l|}{} & Borrachudo \\
\hline Ordem Blataria & Borrachudo & Barata \\
\hline Ordem Homoptera & Barata & Cigarra \\
\hline ORDEM ARACNIDA & Cigarra & $\begin{array}{l}\text { Aranha 2 } \\
\text { Escorpião }\end{array}$ \\
\hline
\end{tabular}




\begin{tabular}{|c|c|c|}
\hline $\begin{array}{l}\text { MOLLUSCA - } \\
\text { GASTROPODA }\end{array}$ & Caramujo & Caramujo \\
\hline PEIXES & & Peixinhos (Só na N-Vale) \\
\hline Astyanax sp & Lambari & Lambari \\
\hline \multicolumn{3}{|l|}{ ANFÍBIOS } \\
\hline ORDEM ANURA & Rã & Rã \\
\hline \multicolumn{3}{|l|}{ RÉPTEIS } \\
\hline & & $\begin{array}{l}\text { Salamandra (considerou como } \\
\text { cobra) }\end{array}$ \\
\hline \multicolumn{2}{|l|}{ ORDEM SQUAMATA } & Cobra 3 \\
\hline \multicolumn{3}{|l|}{ Boidae } \\
\hline Constrictor constrictor & Jibóia & Jibóia 3 \\
\hline \multicolumn{3}{|l|}{ Colubridae } \\
\hline $\begin{array}{l}\text { Phyllodryas aestivus } \\
\text { Phyllodryas olfersi }\end{array}$ & Cobra-verde & Cobra-verde 2 \\
\hline Spillotes pullatus & Caninana & Caninana \\
\hline $\begin{array}{l}\text { Erythrolampus aesculapi } \\
\text { Oxyrhopus trigeminus }\end{array}$ & Coral-não-venenosa & \multirow{3}{*}{$\begin{array}{l}\text { Coral } 7 \text { (confirmado por morador } \\
\text { que encontrou em casa, não dá } \\
\text { pra saber se é a falsa) }\end{array}$} \\
\hline \multicolumn{2}{|l|}{ Elapidae } & \\
\hline Micrurus coralinus & Coral-venesosa & \\
\hline \multicolumn{3}{|l|}{ Crotalidae } \\
\hline Crotalus durissus & Cascavel & Cascavel 3 \\
\hline \multicolumn{3}{|l|}{ Viperidae } \\
\hline Bothrops jararacussu & Jararacuçu & Jararacão (Jaracuçú) 2 \\
\hline Bothrops jararaca & Jararaca & Jararaca 3 \\
\hline Bothrops alternatus & Urutu-cruzeiro & Urutu 2 \\
\hline \multicolumn{3}{|l|}{ Teiidae } \\
\hline Tupinambis teguixin & Lagarto-teiú & *Teiú 3 , Lagarto 4 \\
\hline \multicolumn{3}{|l|}{ ORDEM DOS SAURÍDEOS } \\
\hline \multicolumn{3}{|l|}{ Amphisbaenidae } \\
\hline Amphisbaena Alba & Cobra-de-duas-cabeças & Cobra-sem-cabeça \\
\hline \multicolumn{3}{|l|}{ MAMÍFEROS } \\
\hline \multicolumn{3}{|l|}{ Ordem XENARTHRA } \\
\hline \multicolumn{3}{|l|}{ Dasypodidae } \\
\hline & Tatu & Tatu 4 \\
\hline \multicolumn{3}{|l|}{ Mirmecofagidae } \\
\hline Tamanduá tetradactyla & Tamanduá, Tamanduá-mirim & Tamanduá (tamanduá-mirim) 2 \\
\hline \multicolumn{3}{|l|}{ ORDEM CARNIVORA } \\
\hline \multicolumn{3}{|l|}{ Canidae } \\
\hline Canis familiaris & Cachorro doméstico & Cachorro 3 \\
\hline \multirow[t]{2}{*}{ Cerdocyon thous } & Cachorro-do-mato & Cachorro-do-mato \\
\hline & & Raposa 6 \\
\hline \multicolumn{3}{|l|}{ Mustelidae } \\
\hline Grison vitatus & Furão & Furão \\
\hline \multicolumn{3}{|l|}{ ORDEM RODENTIA } \\
\hline Hydrochaeridae & & \\
\hline Hydrochoerus hydrocoeris & Capivara & *Capivara 2 (vi pegada) \\
\hline Muridae & & \\
\hline Rattus rattus & Rato-de-casa & Rato (ratazana) 7 \\
\hline & & Ratão guaiquira \\
\hline Caviidae & & \\
\hline Cavea aperea & Preá & Preazinho \\
\hline Erethizontidae & & \\
\hline Coenduou sp. & Ouriço-cacheiro & Ouriço (porco-espinho) \\
\hline Agoutidae & & \\
\hline Agouti paca & Paca & Paca \\
\hline ORDEM LAGOMORPHA & & \\
\hline Leporidae & & \\
\hline
\end{tabular}




\begin{tabular}{|c|c|c|}
\hline \multicolumn{3}{|c|}{$\begin{array}{l}\text { Quadro 16: Percepção da comunidade em relação à fauna (exceto avifauna) da Microbacia do } \\
\text { Córrego da Água Ouente (continuacão). }\end{array}$} \\
\hline Ordem/Família/Espécie & Ordem/Família/Espécie & Ordem/Família/Espécie \\
\hline Sylvilagus brasiliensis & Lebre-brasileira, tapeti & Coelho (coelho-do-mato) 5 \\
\hline \multicolumn{3}{|l|}{ ORDEM MARSUPIALIA } \\
\hline \multicolumn{3}{|l|}{ Didelphidae } \\
\hline Didelphis marsupialis & Gambá & Gambá \\
\hline Equus caballus & Cavalo & Cavalo 4 \\
\hline Bos taurus & Vaca/boi & Vaca 3 \\
\hline
\end{tabular}

Quadro 16: Percepção da comunidade em relação à fauna (exceto avifauna) da Microbacia do Córrego da Água Quente.

Foram citadas 38 possíveis espécies de animais (com exceção da avifauna). É importante ressaltar que tanto para a avifauna quanto para os demais grupos de animais, devido ao grau de generalização utilizado pelas(os) respondentes, não foi possível comparar todos os nomes de animais citados com a classificação da literatura. O mesmo ocorreu para alguns nomes atribuídos às espécies vegetais.

Podemos perceber que é notável o grande número de vezes em que são citados animais como insetos (moscas, mosquitos e pernilongos), aranhas, escorpiões, e serpentes, sempre associados a sensações desagradáveis como medo, risco de transmissão doenças e desconforto. Portanto, a fauna pode ser considerada um dos fatores responsáveis pelas relações de topofobia com a área verde.

Algumas espécies encontradas na área verde durante o desenvolvimento dessa pesquisa que podem servir como espécies-bandeira em projetos de EA não foram citadas pela comunidade, como Ramphastos toco (tucanuçú), Mazama americana (veado-mateiro) e Penelope superciliaris (jacupeba). Isto porque provavelmente são espécies raras nesse ecossistema.

Dentre todos os animais citados, praticamente a metade são aves, provavelmente porque a maioria das aves é de fácil visualização ou audição se comparadas a outros grupos de animais, e também porque várias delas freqüentam os bairros adjacentes em busca de alimentos.

Pela sua beleza e facilidade de apreensão e comércio, as aves são as principais vítimas do comércio ilegal de animais na microbacia, conforme observamos inúmeras vezes durante o desenvolvimento do projeto, e de acordo com nossa observação, Sporophila caerulescens (coleirinha) é a espécie mais comumente comercializada na microbacia. Nesse contexto, fica expressa a urgência de projetos de EA no local voltados à sensibilização para a importância da conservação das espécies para a 
manutenção do equilíbrio ecológico, e o papel das aves como biocontroladoras das populações de insetos, polinizadoras e dispersoras de sementes. Esses projetos podem envolver temas como a biopirataria e a lei de crimes ambientais, mas vale lembrar que esse será um grande desafio para as(os) educadoras(es), uma vez que existe o risco desses projetos gerarem conflitos, pois há várias pessoas na microbacia que exercem esse tipo de comércio.

\section{VEGETAÇÃO}

As espécies vegetais citadas abrangeram arbóreas, arbustivas e herbáceas nativas do cerrado e da floresta de transição e algumas exóticas, e compõem o quadro 17, juntamente com sua classificação baseada em Lorenzi, (1998a), Lorenzi (1998b), Lorenzi e Matos (2002), Lorenzi (2003), Durigan et al. (2004) e Ribeiro et al. (2001).

\begin{tabular}{|c|c|c|}
\hline \multicolumn{2}{|c|}{ LEVANTAMENTO “IN LOCO” } & \multirow{2}{*}{\begin{tabular}{l}
\multicolumn{1}{c}{ CONHECIMENTO DA } \\
COMUNIDADE \\
$\begin{array}{l}\text { Nome popular (percepção da } \\
\text { comunidade) e número de } \\
\text { citações }\end{array}$
\end{tabular}} \\
\hline Ordem/Família/Espécie & Nome popular (levantamento) & \\
\hline Bignoniaceae & Ipê (há várias espécies) & *Ipê \\
\hline $\begin{array}{l}\text { Bignoniaceae } \\
\text { Tabebuia aurea }\end{array}$ & Ipê-amarelo do-cerrado & *Ipê-amarelo 3 \\
\hline $\begin{array}{l}\text { Bignoniaceae } \\
\text { Tabebuia avellanedae }\end{array}$ & Ipê-rosa, ipê-roxo & $\begin{array}{l}\text { *Ipê-rosa } \\
\text { *Ipê-roxo } 3\end{array}$ \\
\hline Compositae & & Candeeiro \\
\hline $\begin{array}{l}\text { Anacardiaceae } \\
\text { Myracrodruon urundeuva; } \\
\text { Schinus terebinthifolia } \\
\text { (mesmas propriedades } \\
\text { medicinais) }\end{array}$ & Aroeira-do-campo & $*$ Aroeira do campo \\
\hline Bromeliaceae & Orquídea (nome genérico) & Orquídea 5 \\
\hline $\begin{array}{l}\text { Umbelliferae } \\
\text { Apiaceae } \\
\text { Foeniculum vulgare }\end{array}$ & Erva-doce, funcho & Erva-doce \\
\hline $\begin{array}{l}\text { Caesalpiniaceae } \\
\text { Hymenaea courbaril }\end{array}$ & Jatobá & Jatobá 2 \\
\hline Rosaceae & Amoreira & Amoreira 2 \\
\hline Annonaceae & & Jaca \\
\hline \multirow[t]{2}{*}{$\begin{array}{l}\text { Myrtaceae } \\
\text { Syzygium sp }\end{array}$} & Jambo & Jambo \\
\hline & & Barba-de-bode \\
\hline $\begin{array}{l}\text { Fabaceae } \\
\text { Myroxylon peruiferum }\end{array}$ & Cabreúva, bálsamo & Cabreúva, \\
\hline
\end{tabular}




\begin{tabular}{|c|c|c|}
\hline & & Arranha-gato 2 \\
\hline $\begin{array}{l}\text { Asteraceae } \\
\text { Baccharis dracunculifolia }\end{array}$ & Alecrim-do-campo, vassourinha & Alecrim \\
\hline $\begin{array}{l}\text { Euphorbiaceae } \\
\text { Phyllanthus niruri }\end{array}$ & Quebra-pedra & Quebra-pedra 2 \\
\hline $\begin{array}{l}\text { Boraginaceae } \\
\text { Heliotropium indicum }\end{array}$ & Crista-de-galo & Crista-de-galo \\
\hline $\begin{array}{l}\text { Compositae } \\
\text { Bidens pilosa }\end{array}$ & Picão & Picão \\
\hline $\begin{array}{l}\text { Euphorbiaceae } \\
\text { Ricinus communis }\end{array}$ & Mamona & Mamona \\
\hline $\begin{array}{l}\text { Lauraceae } \\
\text { Persea americana }\end{array}$ & abacateiro & Abacate 2 \\
\hline $\begin{array}{l}\text { Leguminosae-Papilionoideae } \\
\text { Fabaceae } \\
\text { Pterodon emarginatus }\end{array}$ & Sucupira, faveiro & Faveiro 2 \\
\hline Mimosaceae & Angico (várias espécies) & Angico 2 \\
\hline $\begin{array}{l}\text { Annonaceae } \\
\text { Annona coriacea }\end{array}$ & Araticum & Pinha \\
\hline $\begin{array}{l}\text { Passifloraceae } \\
\text { Passiflora } s p .\end{array}$ & Maracujá, maracujá-silvestre & Maracujá-do-mato \\
\hline Polypodiaceae & Samambaia (nome genérico) & $\begin{array}{l}\text { Samambaia } 3 \\
\text { samambaia do mato } \\
\text { samambaia do reino }\end{array}$ \\
\hline Bromeliaceae & $\begin{array}{l}\text { Bromélia } \\
\text { (nome genérico) }\end{array}$ & $\begin{array}{l}\text { Bromélia } 2 \\
\text { Aquela flor parasita que dá no } \\
\text { tronco da árvore tem de monte }\end{array}$ \\
\hline $\begin{array}{l}\text { Lamiaceae } \\
\text { Hyptis suaveolens } \\
\text { Ocimum gratissimum }\end{array}$ & $\begin{array}{l}\text { Alfavacão (duas espécies com o } \\
\text { mesmo nome popular) }\end{array}$ & Alfavacão \\
\hline $\begin{array}{l}\text { Amaranthaceae } \\
\text { Alternanthera brasiliana }\end{array}$ & Terramicina, carrapichinho & Terramicina \\
\hline $\begin{array}{l}\text { Vitaceae } \\
\text { Cissus verticillata }\end{array}$ & Insulina, insulina-vegetal & Insulina \\
\hline $\begin{array}{l}\text { Myrtaceae } \\
\text { Psidium guajava }\end{array}$ & Goiabeira & Goiabeira 2 \\
\hline $\begin{array}{l}\text { Rutaceae } \\
\text { Citrus limon }\end{array}$ & Limoeiro & $\begin{array}{l}\text { Limoeiro } \\
\text { Limão-do-campo (caipira) }\end{array}$ \\
\hline $\begin{array}{l}\text { Leguminosae-Mimosoideae } \\
\text { Stryphnodendron adstringens }\end{array}$ & Barbatimão-verdadeiro & Barbatimão \\
\hline $\begin{array}{l}\text { Myrtaceae } \\
\text { Calyptranthes concinna }\end{array}$ & Guamirim & Guarimirim \\
\hline Didymopanix vinnosum & Mandioqueiro-anão & Mandiocão d'água \\
\hline $\begin{array}{l}\text { Bignoniaceae } \\
\text { Jacaranda } s p \\
\end{array}$ & Carobinha-do-campo & Carovinha \\
\hline \multirow[t]{2}{*}{$\begin{array}{l}\text { Liliaceae } \\
\text { Aloe sp }\end{array}$} & Babosa & Barbosa \\
\hline & Ameixa amarela, nêspera & Ameixa \\
\hline $\begin{array}{l}\text { Myrtaceae } \\
\text { Myrciaria cauliflora }\end{array}$ & Jabuticabeira, jaboticaba & Jaboticaba \\
\hline Musa paradisíaca & Bananeira & Bananeira \\
\hline Bromeliaceae & Gravatá, caraguatá & Gravatá \\
\hline Classificação não encontrada & & Capeva \\
\hline
\end{tabular}

Quadro 17: Comparação entre o levantamento e a percepção da comunidade em relação à vegetação da Microbacia do Córrego da Água Quente. 
Das 41 espécies vegetais conhecidas/percebidas pela comunidade, 24 foram observadas no levantamento in loco, e sete não são nativas daquele ecossistema, como jabuticabeira, bananeira e ameixeira, sendo plantadas nos quintais adjacentes à área verde. Algumas espécies características do cerrado citadas foram Stryphnodendron adstringens (barbatimão), Tabebuia aurea (ipê-amarelo-do-cerrado), Bromelia antiacantha (caraguatá) e Annona coriacea (araticum), e entre as espécies da floresta de transição as espécies Anadenanthera falcata (angico) e Didymopanix vinnosum (mandioqueiro-anão). As espécies conhecidas pela comunidade, assim como as encontradas nos levantamentos identificaram um ecossistema formado por uma composição de espécies característica de zonas de tensão ecológica, em que a variação nas condições locais de solo e umidade propicia ambientes ecologicamente distintos.

Apesar da maior facilidade de contato com as espécies vegetais e da grande diversidade resultante do mosaico de formações vegetais presentes, percebemos um maior conhecimento da comunidade em relação à fauna. Segundo Marin (2003), essa discrepância entre o conhecimento da flora e da fauna pode ser discutida com base no instinto biofílico. Segundo esse princípio, o ser humano que é uma espécie animal, tende a se aproximar e a perceber mais naturalmente os seus semelhantes (MARIN, 2003).

Na definição de Wilson (1993), a Biofilia é a afiliação emocional e inata do ser humano para com outros organismos vivos. $\mathrm{O}$ autor afirma que a diversidade biológica contribuiu para o desenvolvimento da inteligência humana, e que a destruição dessa diversidade mina a nossa inteligência, e que esse instinto biofílico acaba substituído por um instinto de degradação, fruto do rompimento com os demais elementos da natureza. Realmente foi observado tanto junto à comunidade quanto às(aos) estudantes que quanto maior o distanciamento em relação à área verde, mais freqüente a topofobia e a percepção dessa paisagem como um problema a ser superado [segundo a classificação de Meinig (1979) citado por Cabral e Buss (2001) sobre a valorização da paisagem].

Questão 22: Há alguma planta com propriedades medicinais ? Qual e para que serve? 
Além do conhecimento da comunidade sobre a existência de plantas medicinais na área verde, também buscamos conhecer os saberes locais sobre as propriedades medicinais e as receitas de medicamentos preparados com essas plantas, descritas no quadro 18.

\begin{tabular}{|c|c|c|c|}
\hline \multicolumn{2}{|c|}{ INFORMAÇÕES DA LITERATURA } & \multicolumn{2}{|c|}{ CONHECIMENTO POPULAR } \\
\hline $\begin{array}{c}\text { NOME CIENTÍFICO E } \\
\text { NOME POPULAR }\end{array}$ & USOS & NOME POPULAR & USOS \\
\hline $\begin{array}{l}\text { Bignoniaceae } \\
\text { Tabebuia avellanedae } \\
\text { Ipê-roxo, ipê-rosa }\end{array}$ & $\begin{array}{l}\text { Madeira para vigas e } \\
\text { assoalhos. Chá da } \\
\text { casca do caule como } \\
\text { antifúngico, } \\
\text { diurético, antibiótico, } \\
\text { esquistossomose, } \\
\text { câncer, lupus }\end{array}$ & *Ipê-roxo 3 & $\begin{array}{l}\text { O ipê roxo é de } \\
\text { fazer remédio pra } \\
\text { câncer. }\end{array}$ \\
\hline $\begin{array}{l}\text { Anacardiaceae } \\
\text { Myracrodruon urundeuva; } \\
\text { Schinus terebinthifolia (duas } \\
\text { espécies com o mesmo } \\
\text { nome popular e com as } \\
\text { mesmas propriedades } \\
\text { medicinais) } \\
\text { Aroeira-do-campo }\end{array}$ & $\begin{array}{l}\text { Banho da cascacomo } \\
\text { antiinflamatório e } \\
\text { cicatrizante, para os } \\
\text { sistemas urinário e } \\
\text { respiratório e } \\
\text { hemorragia uterina, } \\
\text { contra fungos e } \\
\text { bactérias, para } \\
\text { inflamações na } \\
\text { garganta e gengiva, } \\
\text { hemorróidas. }\end{array}$ & Aroeira-do-campo, & $\begin{array}{l}\text { É uma madeira que } \\
\text { solta uma resina pra } \\
\text { lavar ferida }\end{array}$ \\
\hline $\begin{array}{l}\text { Leguminosae- } \\
\text { Papilionoideae } \\
\text { Fabaceae } \\
\text { Myroxylon peruiferum } \\
\text { Cabreúva, bálsamo }\end{array}$ & $\begin{array}{l}\text { Folhas, frutos e } \\
\text { resina para asma, } \\
\text { bronquite, catarro, } \\
\text { tuberculose, } \\
\text { reumatismo, } \\
\text { torcicolo, sarnas, } \\
\text { impingens, bichos- } \\
\text { de-pé, ulcerações } \\
\text { superficiais, frieiras, } \\
\text { laringite e disenteria. }\end{array}$ & Cabreúva, & $\begin{array}{l}\text { o banho com a casca } \\
\text { dela é boa pra fazer } \\
\text { remédio pra } \\
\text { grosseira que sai no } \\
\text { corpo }\end{array}$ \\
\hline $\begin{array}{l}\text { (Classificação não } \\
\text { encontrada) }\end{array}$ & & Arranha-gato 2 & $\begin{array}{l}\text { é uma planta boa } \\
\text { pra dente } \\
\text { infeccionado (ferve } \\
\text { a raiz do arranha- } \\
\text { gato e faz } \\
\text { bochecho). }\end{array}$ \\
\hline $\begin{array}{l}\text { Compositae } \\
\text { Bidens pilosa }\end{array}$ & $\begin{array}{l}\text { Infusão para angina, } \\
\text { diabetes, disenteria, } \\
\text { aftosa, hepatite, } \\
\text { laringite, verminose, } \\
\text { icterícia, infecções } \\
\text { bacterianas }\end{array}$ & Picão & $\begin{array}{l}\text { que ajuda a } \\
\text { combater a hepatite }\end{array}$ \\
\hline $\begin{array}{l}\text { Leguminosae-Mimosoideae } \\
\text { Stryphnodendron } \\
\text { adstringens }\end{array}$ & $\begin{array}{l}\text { Empregado na } \\
\text { indústria de } \\
\text { curturme. Decocto } \\
\text { da casca para } \\
\text { diarréia, hemorróida, } \\
\text { leucorréia, } \\
\text { hemorragias, }\end{array}$ & Barbatimão & $\begin{array}{l}\text { Tem serventia para } \\
\text { cicatrizar casco de } \\
\text { animal, para lavar } \\
\text { pereba, pra sarar } \\
\text { coceira. A gente } \\
\text { amassa e bota em } \\
\text { cima da ferida, se é }\end{array}$ \\
\hline
\end{tabular}




\begin{tabular}{|c|c|c|c|}
\hline & $\begin{array}{l}\text { conjuntivite, limpeza } \\
\text { de ferimentos, } \\
\text { cicatrizante, } \\
\text { inflamações de } \\
\text { gargante, corrimento } \\
\text { vaginal }\end{array}$ & & $\begin{array}{l}\text { pra banho tem que } \\
\text { ferver pra curar } \\
\text { coceira do corpo, } \\
\text { usa a casca da } \\
\text { árvore. }\end{array}$ \\
\hline $\begin{array}{l}\text { Bignoniaceae } \\
\text { Jacaranda sp } \\
\text { carobinha-do-campo }\end{array}$ & & carovinha & $\begin{array}{l}\text { que é bom pra } \\
\text { bexiga }\end{array}$ \\
\hline $\begin{array}{l}\text { Liliaceae } \\
\text { Aloe } s p \\
\text { babosa }\end{array}$ & $\begin{array}{l}\text { Sumo e mucilagem } \\
\text { cicatrizante para } \\
\text { queimaduras e } \\
\text { feridas da pele e } \\
\text { revitalizante dos } \\
\text { cabelos }\end{array}$ & barbosa & pra lavar o cabelo \\
\hline $\begin{array}{l}\text { Bromeliaceae } \\
\text { Bromelia antiacantha } \\
\text { Gravatá, caraguatá }\end{array}$ & $\begin{array}{l}\text { Xarope da polpa do } \\
\text { fruto para tosse, } \\
\text { asma, bronquite, } \\
\text { ancilostomíase. }\end{array}$ & Gravatá & tosse \\
\hline $\begin{array}{ll}\text { (classificação } & \text { não } \\
\text { encontrada) } & \end{array}$ & & Capeva & $\begin{array}{l}\text { É pra problema de } \\
\text { estômago, Põe a raiz } \\
\text { na água, deixa curtir } \\
\text { e toma a água que é } \\
\text { bom pro estômago. } \\
\text { Dá pra fazer } \\
\text { lavagem também } \\
\text { em ferida, a folha } \\
\text { tem um cheiro } \\
\text { gostoso. }\end{array}$ \\
\hline
\end{tabular}

Quadro 18: Comparação entre as propriedades medicinais e outros usos de algumas espécies vegetais descritas pela comunidade e as informações encontradas na literatura (LORENZI e MATOS, 2002; BONTEMPO, 1994 e BRÜNING, 2003).

Além das informações sobre vegetação obtidas nas 40 entrevistas, tivemos a participação de um morador da microbacia no levantamento das espécies vegetais, com quem realizamos três visitas à área verde. O Sr. Antônio de Oliveira, que é morador do Jardim Gonzaga e grande conhecedor de espécies vegetais e de suas propriedades medicinais participou na identificação de várias espécies (descritas no anexo 15, com os nomes por ele dados e comparados com informações encontradas em Lorenzi, 1998a; Lorenzi, 1998b; Lorenzi, 2002; Lorenzi, 2003; Durigan et al. 2004 e Ribeiro et al., 2001) e descreveu seus usos mais comuns pelo ser humano.

Nesse levantamento preliminar foram identificadas 70 espécies vegetais, sendo 34 indicadas como plantas medicinais pelo Sr. Antônio ou pelos autores acima citados.

Apesar de ter sido realizado um levantamento preliminar dos componentes da área verde, a partir das entrevistas e da observação direta, pudemos constatar que a área verde possui considerável biodiversidade animal e vegetal, havendo na verdade um 
número de espécies muito maior do que o que aparece nas entrevistas, levando a crer que a maioria da população conhece relativamente pouco da riqueza ecológica da área verde, o que poderia contribuir muito para a conscientização sobre a importância da conservação da mesma. Para tanto, são necessários mais estudos de levantamento da biodiversidade local e a implementação de projetos de Educação Ambiental junto a essa população. Vislumbrando esses estudos, vale lembrar que existem algumas pessoas na microbacia que conhecemos após a realização das entrevistas, e portadoras de grande conhecimento sobre a biodiversidade da área verde. Tanto para os levantamentos florísticos quanto para os projetos de Educação Ambiental é de fundamental importância a participação de pessoas como o Sr. Antônio que, além de líder no bairro Jardim Gonzaga e portador de inúmeras informações sobre a área verde, também possui com a área uma relação extremamente topofílica, baseada em suas origens no Mato Grosso e em toda a sua história de vida.

Consideramos que esse saber, muitas vezes registrado apenas nas memórias, merece ser resgatado por fazer parte da cultura e dos modos de vida local, e porque caracteriza inclusive uma forma alternativa (mais barata e mais saudável) de garantir a saúde da população.

Projetos de EA que enfoquem o resgate dos saberes locais sobre as plantas medicinais da área verde como tema-gerador, poderão trabalhar a importância do resgate e da resistência das culturas locais frente ao processo de massificação imposto pela globalização através da mídia, e a importância da conservação da área verde também pela riqueza da diversidade de espécies vegetais como banco de princípios ativos naturais.

\section{PAISAGEM}

De acordo com o quadro 19, além dos componentes naturais que aparecem nas demais respostas, a paisagem também é composta por morros, rochas e até uma gruta, citada por várias(os) moradoras(es) da microbacia em conversas informais. Durante a pesquisa, não foi possível conhecer esse local, mas várias pessoas afirmam que, apesar de impactado, é um lugar bonito que merece recuperação. 
“O rio, as pedras, a mata, só isso”.

“Lá embaixo já é uma matinha fechada. Eu vou lá dar uma olhada, vou curtir o tempo, então tem um morro lá embaixo, a gente sobe em cima dumas pedras lá, fica olhando lá pra baixo, lá do morro dá pra ver bastante, avista longe. (...)

Tem uma grutinha lá embaixo, a gruta é lá do outro lado, tem que ir por lá, entra por baixo, aí você vê a rocha com as pedras onde a água passa. Mas agora, joga as coisa tudo lá dentro, sujou tudo, né? Mas a gruta, se conservasse ela bem limpinha, ficava bonitinha, mas a rede de esgoto passa dentro, fica difícil".

“Antes era, não é mato grande, antes era grama, tem 2 morros aqui embaixo, um diferenciado do outro, um era de pedra, outro era de mato".

Quadro 19: Componentes da paisagem da MCAQ segundo a percepção das pessoas entrevistadas.

De acordo com Guimarães (2001), as concepções iniciais sobre "paisagem" relacionavam-se no passado mais a aspectos e valores estéticos, sofrendo várias modificações através dos tempos, mas perdurando uma conotação associada à percepção visual que se preocupa com a beleza da composição, do cenário. Nestas concepções não se encontram reflexões ou preocupações de caráter ecológico, referentes aos conceitos de "qualidade ambiental" e de "qualidade de vida". Já neste estudo de percepção da paisagem, encontramos várias falas, tanto da comunidade quanto dentre as(os) estudantes, que se reportam à beleza da paisagem em contraste com a degradação do ecossistema, e algumas podem ser observadas nos exemplos a seguir.

“Mata faz bem pra gente. O verde é bom, quando está seco fica feio. Quando está verde fica bonito”.

"Faz bastante tempo que eu moro aqui, já acostumei com essa mata... Claro que o povo está acabando, o pessoal taca fogo. Mas logo quando eu cheguei aqui, era muito verde, era lindo demais! Agora ainda está bonito, mas muita coisa mudou desde quando eu estou aqui”.

"Eu achava que devia cuidar dessa mata melhor ainda, pra poder manter bonita como ela é, porque o verde é muito bonito assim pra gente sair, conhecer assim num dia bonito de sol, a gente ver esses pés de árvore verde é muito bonito, sentir o gostinho do mato, então eu gostaria que se cuidasse melhor da mata".

Isto posto, em virtude da percepção das pessoas que participaram desta pesquisa e da nossa observação, acreditamos que apesar do adiantado estágio de impactação em que a área verde se encontra, ainda existem trechos em que a paisagem é bela e rica do ponto de vista da variedade de cores e formas, devido aos diferentes tipos de solo da 
área verde responsáveis pela existência de diversas formações vegetais, e do relevo que varia de planícies a cuestas.

Devido à acentuada degradação ambiental diagnosticada principalmente em áreas naturais de ecossistemas urbanos, vários trabalhos têm sido desenvolvidos em busca de medidas para recuperar e/ou conservar essas áreas. Contudo, muitos destes trabalhos têm caráter pontual e não alcançam seus objetivos por basearem-se apenas nos métodos tradicionais de pesquisa e intervenção e não considerarem as relações da população com o ambiente, sob um enfoque topofílico.

Foi possível observar nas falas das pessoas mais antigas no local, um maior conhecimento da história de ocupação da microbacia, uma comparação entre a qualidade ambiental da área verde no passado e atualmente, principalmente em relação aos corpos d'água, e algum conhecimento sobre os atuais proprietários de trechos da área verde, que representam a maior extensão da área.

Machado (1988) acredita que um estudo da interação entre o ser humano e a paisagem deve considerar a sua percepção e a atribuição de valores e tomada de posições, e envolver tanto os componentes naturais e construídos da paisagem, como as manifestações topofílicas das pessoas que "passam ali toda sua vida". Concordamos com o autor e acreditamos que estudos de percepção ambiental como este podem contribuir para a elaboração de projetos e propostas de manejo de paisagens ameaçadas.

\section{IMPACTOS AMBIENTAIS}

Assim como pudemos avaliar através das análises limnológicas, também no estudo da percepção detectamos a emissão de efluentes domiciliares na área verde como um dos mais graves impactos ambientais, sendo o mais citado pelas(os) entrevistadas(os), num total de 25 pessoas, e sempre associado à poluição e mau cheiro (citado por 15 pessoas). Como a canalização de esgoto é de responsabilidade do governo municipal, talvez essa questão justifique o argumento de que a principal responsável pela atual qualidade ambiental da área verde é a prefeitura. O segundo impacto ambiental mais marcante, comentado por 19 pessoas, é a presença dos mais diversos tipos de resíduos sólidos, desde vidro, tábua, pedaço de sofá, cadeira velha, roupas velhas, latas, até animais mortos, como cachorro e cavalo. As queimadas também causam um impacto bastante evidente, citado por $25 \%$ das(os) respondentes, e 
que se agrava no período seco, em cujos meses é possível observar queimadas em trechos da área verde quase que diariamente. Essa prática de atear fogo à vegetação faz parte da cultura de grande parte da população e constitui um tema importante e urgente para os projetos de EA a serem desenvolvidos na microbacia.

Quanto aos impactos mais relacionados ao componente humano do ambiente, várias pessoas, de maneira mais ou menos explícita, declararam que a área verde vem sendo utilizada como um local para refúgio e esconderijo de delinqüentes. Porém, durante as entrevistas, apenas duas pessoas referiram-se especificamente ao problema das drogas e uma respondente contou que foi encontrada uma pessoa morta na área.

$\mathrm{Na}$ Figura 49 observam-se os impactos ambientais citados pelas(os) participantes e o número de citações.

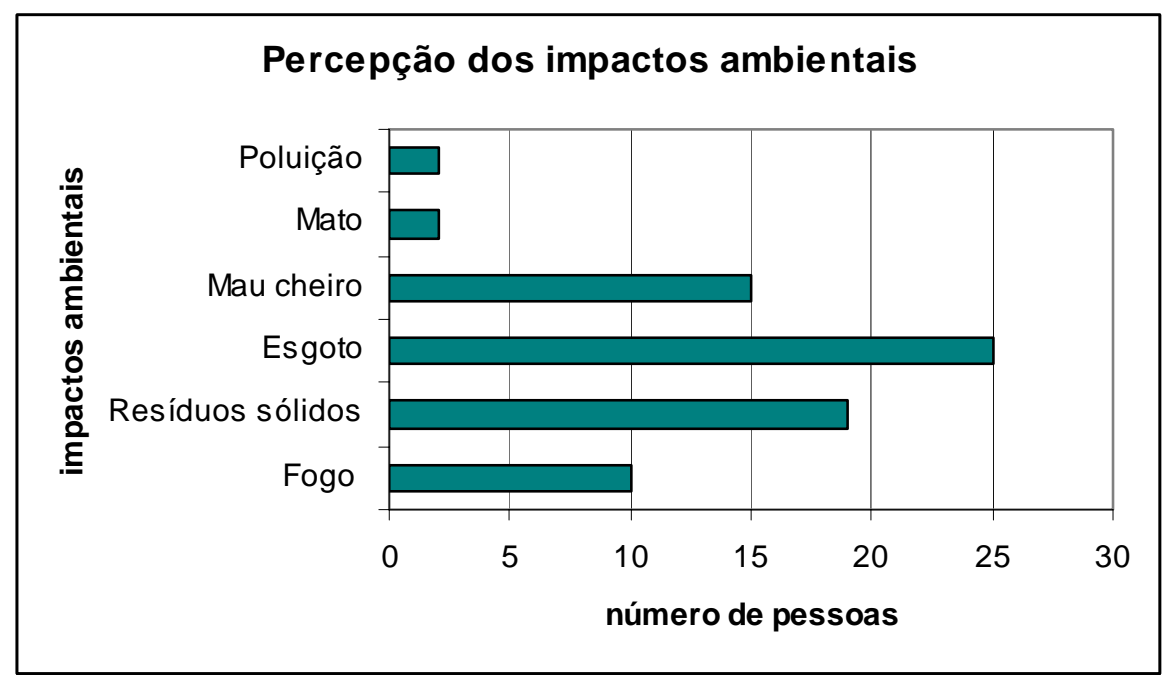

Figura 49: Principais impactos ambientais da área verde, segundo a percepção da comunidade.

\section{CORPOS D’ÁGUA}

De acordo com Lima (2003), há bem poucos estudos sobre o gerenciamento de recursos hídricos ou sobre o desenvolvimento urbano com enfoque em bacias hidrográficas, que consideram a percepção ambiental da população como fonte de informações. Além disso, raramente a população tem acesso aos dados técnicos produzidos a partir dessas pesquisas, ficando alheia à situação ambiental da bacia hidrográfica da qual fazem parte. 
Kunieda (2003) estudou a percepção ambiental da comunidade que reside e/ou trabalha na fazenda Canchim-Embrapa (São Carlos, SP), em relação à microbacia onde do Ribeirão Canchim, com ênfase nesse corpo d'água e em espécies-bandeira componentes da avifauna da mata mesófila que circunda as nascentes do mesmo. A autora pôde observar que os diferentes papéis sociais exercidos pelos indivíduos participantes (moradoras da colônia, funcionários residentes, funcionários não residentes e pesquisadores) orientam sua capacidade perceptiva do entorno. Também descobriu que as três espécies-bandeira escolhidas não são conhecidas pela comunidade e poucas pessoas estabeleceram a ligação entre a água que consomem, a nascente na mata de entrada e o Ribeirão Canchim.

De acordo com a Figura 50, que indica a percepção da comunidade em relação à água é possível notar que a maioria das pessoas entrevistadas percebe a existência de algum corpo d'água na área verde da microbacia, predominando a percepção da existência de nascentes (ou minas), citadas em 49\% das respostas. Em relação à presença de córrego(s), 27\% sabem da existência de um córrego e 4\% citam dois córregos, mas desconhecem seus nomes. Somente $8 \%$ citam de fato o Córrego da Água Quente, e outros 12\% referem-se ao Córrego da Água Fria ou Rio do Monjolinho, que não pertencem à microbacia estudada. Além destas respostas, 17,5\% desconhecem a existência de qualquer corpo d'água na área verde e 7,5\% acreditam que o que viram são "córregos" formados exclusivamente por esgoto.

A partir desses resultados, pode-se notar o pouco conhecimento existente em relação ao Córrego da Água Quente que, além de dar nome à microbacia, vem sofrendo sérias modificações em decorrência do uso inadequado desta. Também fica claro que parte da população desconhece a localização do Córrego da Água Fria e o confunde com o Córrego da Água Quente, até porque situam-se relativamente próximos. O fato de existirem pessoas que percebem somente a presença de esgoto quando se pergunta sobre a existência de água, indica a intensidade do impacto que sofreram e sofrem os corpos d'água da área verde, a ponto de serem desconfigurados e confundidos com "córregos de esgoto". Para essas pessoas, um dos principais elementos naturais que justificam a importância da recuperação e conservação da área já não existe ou nem sequer existiu.

Lima (2003) ao estudar a percepção ambiental da população da área urbana de São Carlos também verificou o pouco conhecimento da população em relação à Bacia Hidrográfica do Monjolinho e suas microbacias, posto que $62 \%$ não conseguiram 
identificar nenhum corpo d'água a partir do mapa mental apresentado e 57\% desconheciam de onde vem a água de abastecimento de São Carlos. Ao apresentar um mapa mental com o traçado dos corpos d'água de São Carlos, somente uma dentre as 40 pessoas entrevistadas conseguiu identificar o Córrego da Água Quente.

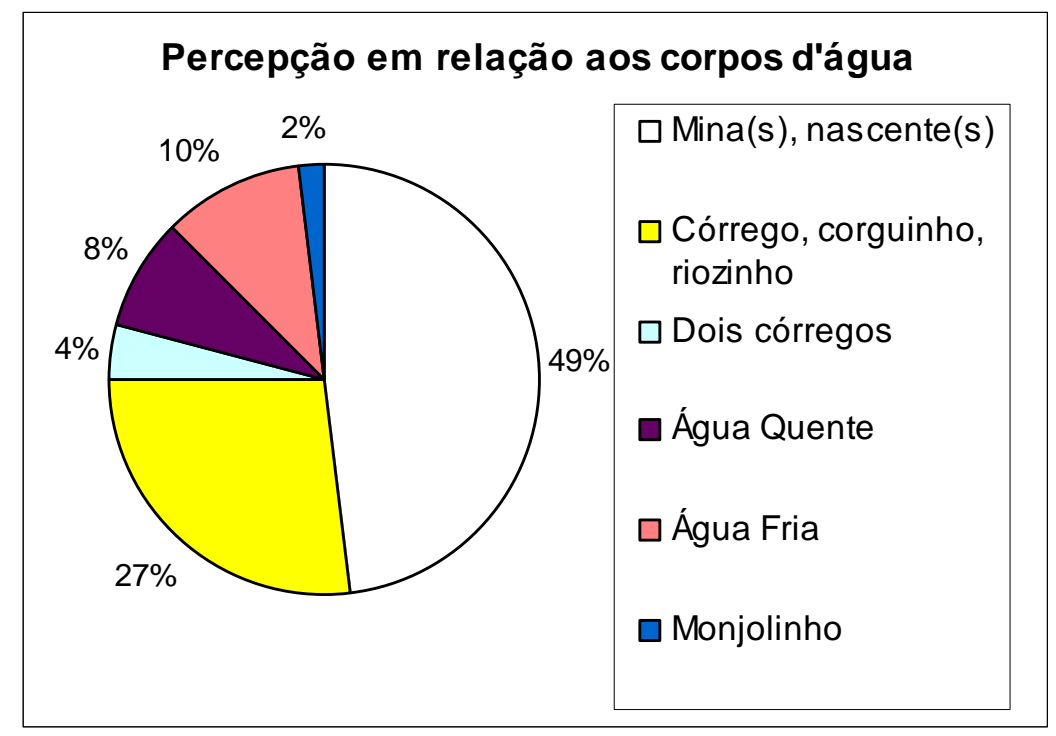

Figura 50: Percepção da comunidade em relação à existência de corpos d'água da área verde da MCAQ.

As três questões seguintes também dizem respeito à percepção da água e são seqüenciais, tendo sido analisadas em conjunto.

Questão 23: Já teve algum contato com a água existente na área de vegetação ? Que tipo de contato?

\section{Questão 24: Como estava a água?}

\section{Questão 25: Você ou alguém de sua família teve alguma alteração no organismo} após ter contato com a água? Qual?

Sabendo-se que o público que freqüenta a área verde faz usos diversificados dos corpos d'água, procuramos analisar quais os tipos mais comuns de contato com essa água, qual a percepção das(os) participantes em relação à água, e quais as possíveis reações no organismo conseqüentes desse contato. Pudemos perceber, conforme a figura 51, que uma porcentagem considerável de pessoas (47,5\%) já teve algum contato físico com a água, praticamente só com as águas das nascentes, sendo que $10 \%$ já entraram na 
água e 35\% já a ingeriram. Nenhuma delas relatou sensações desagradáveis ou reações prejudiciais à saúde após o contato com a água, que tenha sido detectada em algum nível. Pelo contrário, todas afirmaram que a água das nascentes estava limpa, fria, cristalina e inodora, e muitos observaram a presença de pequenos peixes. Várias(os) moradoras(es) da microbacia inclusive buscaram água das nascentes para utilizar em suas residências. Porém, a grande maioria conviveu com a água no passado, e sabe que atualmente esse contato é inadequado devido à contaminação.

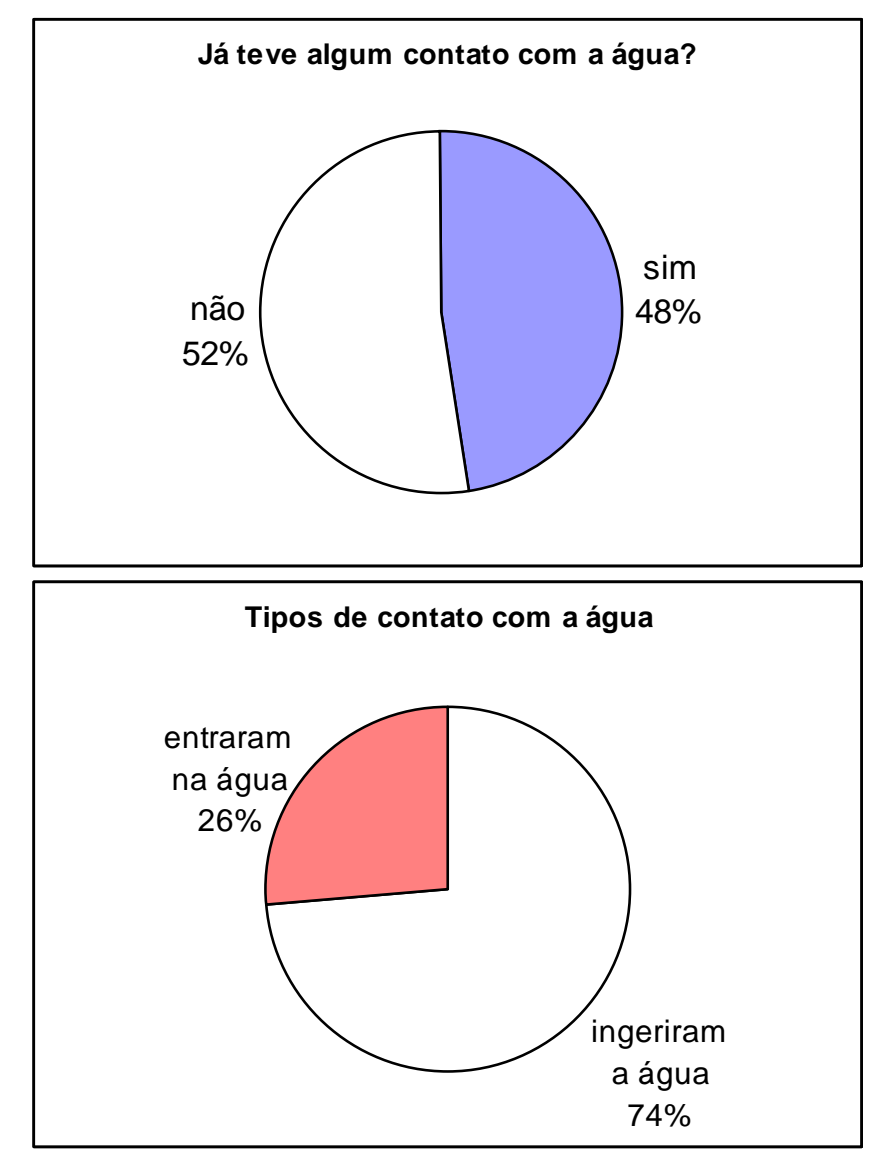

Figura 51: Contato da população com os corpos d'água da área verde da microbacia.

No quadro 20, estão alguns depoimentos sobre as relações estabelecidas com a água, e as comparações entre a qualidade da água no passado e no presente. 
"A gente tomava, porque a água era limpinha, transparente, agora está suja, então já não dá mais pra tomar. A gente pisava na água e nunca sentiu nada”.

"Naquele tempo era gostoso, natureza, a água era limpa, tinha um Corguinho ali, e a gente podia beber água, a água era limpinha, hoje não. Hoje não, hoje já estragaram tudo, a cidade joga a rede de esgoto dentro, não tem mais aquele lazer de você falar assim, vou passar aqui, né? ichi, nadava, bebia água, tinha um riozinho lá que cobria você, lá era fundo e a gente brincava ali. Ah, isso já faz uns 20 anos mais ou menos. Não bebo mais, agora não tem mais nada, agora só tem uma mininha, mas ela é limpa. Se conservasse ela, se tratasse, se a prefeitura fizesse um tanque e tratasse dela bem ali, todo mundo vinha pegar água aí, tinha certeza, a água é limpa”.

"Já bebi, mas não bebo mais. A gente ia lavar roupa lá embaixo. Naquele tempo não era, mas agora é poluído. Aquela água que tem lá embaixo, era bonita, era um cristal, de domingo nós íamos lavar roupa lá embaixo. Minha filha mais nova tinha 5 meses. A mina era lá no começo do muro (encosta do Gonzaga), lá em cima. Tem essa aqui que tem um pouquinho de água (Pacaembú). Mas agora é poluído, todo o esgoto que vem da cidade é jogado aí. O nosso esgoto mesmo aqui, joga lá embaixo, e daquelas vilas tudo, cai aqui. Nunca ninguém da família teve nenhuma doença por ter contato com a água. Agora já é diferente. É muito diferente lá”.

"Tinha a passagem da chuva que se você passar naquele morro que eu falei, passando direto, ou naquela vila lá em cima (Monte Carlo), descendo ela reto, conforme ta descendo ali, lá embaixo tem uma mina, limpinha, limpinha, branca, branca, branca. Aí tem água que desce de esgoto, mas tudo em lugar separado. A água dá pra beber, é uma água gelada. Porque a gente veio do Paraná, a gente já morava em mato, então a gente já conhece tudo, e ali você vê a água subindo. Água tomei já faz uns 3 anos (2001), já nadei, a água é cristalina, é gelada, mas é um gelo, acho que é porque é na sombra, inseto tem bastante, pernilongo, mas hoje em todo lugar tem".

"De vez em quando a gente ia brincar na água, eu, minha mulher, naqueles tempos... (do buracão). A água era limpinha, bonita, hoje é tudo uma porcaria. Mas naqueles tempos era bonito, tinha aqueles morros, descendo lá embaixo é bonito, é gostoso. Antigamente a água podia beber, mas hoje não pode mais".

"Tem várias minas, a mais forte é da cabeceira do Gonzaga. As outras ficam nos barrancos das pedras. Ela sai limpinha, mas já está contaminada. Tem gente que está tirando água, fervendo em casa pra beber. Ferve e côa, ela sai branquinha. Dá pra por bambu pra fazer uma canaletinha pra puxar a água. Córrego é o principal do meio ali do ambiente que corre e penetra. É o que vai sair lá no Matadouro, emenda lá com o Feijão, não, com o Gregório, vai descendo, fazendo a volta e emenda lá com o Gregório.

Tomei a água já faz uns 17 anos. Era limpinha, geladinha, não precisava nem por na geladeira, cristalina, podia por pra criança tomar sem precisar ferver, era limpa mesmo. Eu tenho de testemunha a família do João Ratti, porque eles usavam, e também quando eles fizeram o supermercado deles, não tinha água ali e eles iam buscar de carroça.

Água Quente é o córrego que desce ali embaixo, que faz parte da Água Fria. É esse daqui (da mata) que emenda aí. Esse daqui vai pra lá, entra na Água Quente, que desce na Água Fria. E ele faz parte e emenda pra cair no Gregório".

"A gente já nadou, que ele forma parte do areieiro lá embaixo. Já nadou, já abriu valeta pra turma da fábrica de toalha, canalizei tudo a água lá. A água do córrego era excelente. Não tinha cheiro, só que era uma água meio azul, meio escura, mas só que quando pegava no copo era branquinha. Nunca senti nada. Eu faço parte da natureza da água. Eu cheguei na água, ponho um pouquinho, o gosto dela eu conheço se ela é doente. Eu faço na própria boca. Se eu pegar um pouquinho, já no sentido do gosto eu sei se a água está boa, se ela é saudável, salobra, então a gente já sabe o gosto que a água tem. Se a água não tiver gosto de barro, excelente água. Se ela puxar gosto de barro, ela está contaminada. Se ela tem gosto já está pegando contaminação. Então ela tem que ser uma água pura, leve, e não ser pesada, porque você bebeu água e sentiu que ela é pesada, pode fazer exame. Ela já está prejudicando o estômago, porque ela é uma água contaminada”.

"O que eu vi foi uma água bonita, a gente podia beber porque era limpinha. Nadamos, eu mais meus meninos, uma colega minha, descemos a rampa, nós estava livre. A água era gostosa, era geladinha, em 


\begin{abstract}
dia de calor".
“Tem mina aí que não seca nunca. Quando eu vim morar aqui, as torneiras de água não venciam, então eu ia com dois baldes buscar lá embaixo. Trazia água pra nós beber e pra nós tomar banho. Já bebi água daí, faz uns dez anos, a temperatura é boa, fria”.

“Tem uma mina lá embaixo que a gente ia buscar água quando faltava água aqui, a gente saía atolado com barro até no joelho, mas a gente ia, trazia água limpinha pra cá, de garrafão, eu conheço só uma mina que fica no topo mesmo. Mas tem um pessoal que diz que pra baixo tem mais uma. O córrego é só o da água suja, do esgoto. Eu já tomei água da mina, quando faltava água a gente buscava de garrafão e trazia 2, 3 pra cá. Já faz uns dois anos que eu peguei água dali. Aí depois nunca mais a gente desceu. Quando tomei a água não, nunca tive problema nenhum. A água é muito limpinha, fresquinha, clarinha, não tem nem comparação com a de torneira, era fria, tinha peixinho. Já ouvi falar no Córrego da Água Quente, só que não conheço”.
\end{abstract}

\title{
Quadro 20: Percepção sobre a qualidade da água no passado e no presente.
}

Embora a maioria das pessoas tenha apresentado uma percepção negativa em relação à atual qualidade dos corpos d'água, ainda assim demonstram topofilia em relação à água e interesse pela sua recuperação. A familiaridade que temos com o lugar, conforme Machado (1988), geralmente nos engendra aceitação e até afeição, que no caso é percebida nas falas, juntamente com o desejo de que as águas sejam cuidadas para recuperarem a qualidade que possuíam no passado.

Ao contrário do que observamos na MCAQ, para Lima (2003) as pessoas entrevistadas na cidade de São Carlos não demonstraram ter estabelecido relações afetivas para com os corpos d'água presentes em seu entorno, e algumas inclusive atestaram que a ocultação dos corpos d'água através de canalização subterrânea poderia aumentar o valor estético da paisagem urbana.

Jacobi (2000a), ao estudar a percepção da população da capital paulista em relação aos córregos e rios urbanos, observou que rios e córregos poluídos aparecem mais nas respostas obtidas junto aos estratos mais carentes da população, residentes em regiões muito afetadas pela degradação ambiental (incluindo-se aqui principalmente os aspectos sociais do ambiente). Em relação aos efeitos que a existência de rios e córregos contaminados ocasionam, os mais destacados são o aumento de insetos e ratos, mau cheiro e doenças infecto-contagiosas. Corroborando com a pesquisa de Jacobi e com essa pesquisa, sabemos que às populações de baixa renda das cidades brasileiras em geral restam somente as zonas periféricas, com corpos d'água freqüentemente impactados. A ocupação do seu entorno agrava ainda mais a qualidade da água e as(os) moradoras(es) próximas(os) são as principais vítimas deste tipo de poluição hídrica. Neste trabalho, entre os impactos ambientais percebidos, os mais lembrados foram os 
relacionados com a poluição hídrica e a degradação dos corpos d'água, como o esgoto a céu aberto no córrego, o mau cheiro que atinge os bairros, e a presença de resíduos sólidos e de animais indesejáveis como ratos, baratas e pernilongos.

\section{Questão 26: Em sua opinião, quem são as pessoas responsáveis pela atual situação do seu bairro e dessa área verde?}

A partir das questões 26 e 27 procuramos estudar a percepção da comunidade em relação à sua responsabilidade pela qualidade ambiental da área verde, dividindo a reflexão em duas partes: a) responsáveis pela situação ambiental atual (tabela 2); e b) responsáveis pela participação nas decisões para o manejo da área (tabela 3).

Tabela 2: Responsáveis pela atual situação dos bairros e da área verde.

\begin{tabular}{|c|c|c|c|}
\hline \multicolumn{2}{|c|}{ BAIRRO } & \multicolumn{2}{c|}{ ÁREA VERDE } \\
\hline Responsáveis & Número de respostas & Responsáveis & Número de respostas \\
\hline Políticos & 1 & $\begin{array}{c}\text { O medo de descer } \\
\text { (local de bandidos) }\end{array}$ & 1 \\
\hline Prefeitura & 12 & Prefeitura & 3 \\
\hline Prefeitura e vereadores & 3 & Prefeitura e vereadores & 2 \\
\hline Vereadores & 1 & $\begin{array}{c}\text { Secretaria do Meio } \\
\text { Ambiente }\end{array}$ & 1 \\
\hline Associação de bairro & 3 & Associação de bairro & 5 \\
\hline $\begin{array}{c}\text { Imobiliária, prefeitura e } \\
\text { antigos donos }\end{array}$ & 1 & $\begin{array}{c}\text { Imobiliária, prefeitura e } \\
\text { antigos donos }\end{array}$ & 6 \\
\hline Moradores locais & 6 & Moradores locais & \\
\hline $\begin{array}{c}\text { Prefeitura e moradores } \\
\text { locais }\end{array}$ & 6 & $\begin{array}{c}\text { Prefeitura e moradores } \\
\text { locais }\end{array}$ & 7 \\
\hline Não sei & 4 & Não sei & 2 \\
\hline Não especificou & 1 & Donos do terreno & \\
\hline
\end{tabular}

Para 45\% das(os) participantes a responsabilidade pelo atual estado do bairro em que residem compete a pessoas externas ao próprio bairro, como políticos em geral, a prefeitura (predominantemente), os vereadores, e as imobiliárias ou os donos dos terrenos. Somente 15\% das pessoas atribuem a responsabilidade à Associação de Bairro, porém apenas três entrevistados ( 2 homens e 1 mulher) participam ou já participaram de uma Associação. Outros 15\% acreditam que a situação deve-se às(aos) próprias(os) moradoras(es) do bairro e ainda outros $15 \%$ indicam como responsáveis tanto a prefeitura como as(os) moradoras(es). Esses resultados atestam que 30\% compreendem sua co-responsabilidade na manutenção do bairro, mas não estão organizados em 
associações, de modo que não se mobilizam para realizar intervenções nos bairros, nem para reivindicar melhorias junto aos órgãos competentes.

Em relação à área verde, os resultados praticamente se repetem, sendo que a Secretaria do "Meio Ambiente"3 é incluída por um respondente entre os responsáveis pela área, e várias(os) participantes (17,5\%) não sabem quem são os responsáveis pela atual situação da área. Portanto, pudemos constatar que grande parte das(os) respondentes desconsideram a co-responsabilidade da população em relação à degradação da área verde, acentuada pelos resíduos sólidos depositados e pelas queimadas provocadas principalmente no período da seca.

Em uma pesquisa realizada nas bacias de dois córregos da cidade de Uberlândia (MG), Silveira e Colesanti (2001) estudaram a percepção ambiental da população em relação àquelas paisagens, concluindo que mais de $60 \%$ dos moradores são favoráveis à recuperação e atribuem a maior responsabilidade por aquelas bacias à Prefeitura Municipal, ao Departamento Municipal de Água e Esgoto e ao IBAMA. Somente 31\% dos moradores atribuíram a si próprios significativa parcela essa responsabilidade.

Na cidade de São Carlos, Lima (2003) constatou que a população não está disposta a participar de ações ambientais em prol da melhoria dos corpos d'água, e justifica a não-participação pela desinformação sobre os eventos e falta de tempo disponível.

\section{Questão 27: Em sua opinião, quem são os responsáveis por decidir o que está bom e o que deve ser mudado na área verde?}

Tabela 3: Responsáveis por decidir sobre as intervenções na área verde.

\begin{tabular}{|c|c|}
\hline Prefeitura & 15 \\
\hline Prefeitura e Universidade Federal & 1 \\
\hline Vereadores & 1 \\
\hline Polícia Florestal & 1 \\
\hline Donos & 1 \\
\hline Prefeitura, vereadores e associações de bairro & 1 \\
\hline Prefeitura e associações de bairro & 1 \\
\hline Prefeitura e moradores locais & 2 \\
\hline População em geral & 5 \\
\hline Moradores locais & 8 \\
\hline Não sei & 4 \\
\hline
\end{tabular}

\footnotetext{
${ }^{3}$ No município de São Carlos a secretaria responsável pela maior parte dos assuntos ambientais é a Secretaria Municipal de Desenvolvimento Sustentável, Ciência e Tecnologia, mas as pessoas entrevistadas não a conhecem por esse nome).
} 
Em consonância com os resultados da questão anterior, $52,5 \%$ das pessoas entrevistadas, afirmaram que as decisões sobre o manejo da área verde são de responsabilidade de órgãos ou indivíduos externos a microbacia, incluindo em primeiro lugar a prefeitura (30\% das respostas), a Universidade Federal de São Carlos, os vereadores, os donos da área e a "Polícia Florestal" (atual Polícia Ambiental). Embora a área verde influencie sensivelmente a qualidade de vida da população da microbacia e a maior parte das(os) participantes demonstre topofilia por esse lugar, poucas pessoas reconhecem o seu direito e dever de participar nas decisões sobre a área da microbacia em que vivem e com a qual convivem e que, direta ou indiretamente, influencia suas vidas. Cinco pessoas (12,5\%) indicam como responsável a população em geral, e apenas $25 \%$ entendem que as(os) moradoras(es) da microbacia devem participar das decisões de manejo. Essa percepção da comunidade confirma a histórica ausência de democracia de nosso país, em que são raros os casos em que houve espaço para a população participar das decisões sobre seu próprio bairro ou locais de uso público. Todavia, dentre os $25 \%$ conscientes da importância desse ato de cidadania, somente uma pessoa atualmente participa de uma Associação de Bairro.

Jacobi (2000b) analisou a percepção da população de três bairros da cidade de São Paulo sobre as possíveis soluções para alguns problemas ambientais daquela cidade relacionados com poluição da água, esgoto, lixo, poluição do ar e presença de insetos e roedores. Nesta pesquisa, o autor observou uma pequena repercussão na percepção da importância da mobilização popular, organização, reivindicação e denúncia relativas a esses problemas ambientais, constatando que o poder público foi indicado como o principal agente para a solução do problema.

\section{Questão 28: Você tem alguma sugestão para mudança ? O que você gostaria que fosse feito na área verde?}

Para que as decisões da gestão tornem-se mais democráticas, a população deve ser consultada, obtendo opiniões e sugestões a fim de subsidiar, com mais informações, novas reflexões para a tomada de decisões (LIMA, 2003). Em relação a essa democracia a que o autor se refere, acreditamos que o que torna as ações ambientais efetivas, 
sustentáveis e permanentes é o engajamento das comunidades locais em todo o processo, deste o planejamento até a implantação e a continuidade das ações.

Nesse sentido, procuramos dar início a esse exercício de ouvir os anseios da comunidade em relação à área verde, cujas sugestões para a elaboração de um plano de manejo estão descritas na Tabela 4.

Tabela 4: Sugestões por gênero para o manejo da área verde da MCAQ.

\begin{tabular}{|l|c|c|c|}
\hline \multirow{2}{*}{ SUGESTÕES DE MANEJO } & \multicolumn{3}{c|}{$\begin{array}{c}\text { NÚMERO DE VEZES QUE EM QUE } \\
\text { APARECEU CADA SUGESTÃO }\end{array}$} \\
\cline { 2 - 4 } & MULHERES & HOMENS & TOTAL \\
\hline Recuperação/conservação/preservação & 8 & 7 & 15 \\
\hline Educação/conscientização da população & 0 & 2 & 2 \\
\hline Canalização da água e do esgoto & 7 & 5 & 12 \\
\hline Tratamento da água para consumo humano & 2 & 1 & 3 \\
\hline Reflorestamento & 2 & 1 & 3 \\
\hline Limpeza do solo & 4 & 4 & 8 \\
\hline Controle das queimadas & 2 & 0 & 2 \\
\hline Fiscalização & 0 & 1 & 1 \\
\hline Estudo da área & 0 & 1 & 1 \\
\hline $\begin{array}{l}\text { Área de lazer (parque ecológico, praça, jardim, } \\
\text { campinho, ciclovia) }\end{array}$ & 1 & 5 & 6 \\
\hline Cercamento (cerca, muro de arrimo) & 6 & 7 & 13 \\
\hline Passarela entre os bairros (ponte) & 3 & 0 & 3 \\
\hline Ruas de asfalto & 6 & 4 & 10 \\
\hline Aterramento total da área verde & 4 & 3 & 7 \\
\hline Loteamento & 4 & 1 & 5 \\
\hline Não sabem & 1 & 1 & 2 \\
\hline $\begin{array}{l}\text { Respostas divergentes em relação à pergunta (não } \\
\text { responderam sobre a área verde) }\end{array}$ & 2 & 0 & 2 \\
\hline
\end{tabular}

As sugestões destacadas demonstram que 15 pessoas $(37,5 \%)$, praticamente o mesmo número de mulheres e homens, estão conscientes da necessidade de recuperação e conservação da área verde. Quando são detalhadas as propostas para recuperação da área verde, predominam o cercamento (32,5\%, sendo 6 mulheres e 7 homens), com cerca ou com muro de arrimo, para aumentar a proteção da área e a segurança daquelas(es) que residem próximos dali; e a canalização da água e do esgoto existentes na área, aparecendo em $30 \%$ das respostas ( 7 mulheres e 5 homens) - podendo-se perceber durante as entrevistas, que muitas pessoas não sabem que, além de esgoto, também existem nascentes na área verde, e outras têm dificuldade para distinguir a água das nascentes dos efluentes domiciliares. Ainda sobre a recuperação da área verde, $20 \%$ das pessoas sugerem a limpeza do solo (retirada de lixo e entulho) e $5 \%$ o controle de queimadas. É importante destacar o pequeno número de participantes que 
apresentam preocupação com a educação ambiental da população em relação à conservação da área verde ( $5 \%$ das respostas) e também a necessidade de estudo e fiscalização da área apontadas por apenas 2,5\% das(os) entrevistadas(os). Jacobi (2000a) também notou junto a pessoas de diferentes estratos sociais residentes em três bairros de São Paulo, essa percepção da necessidade de intervenções educativas para a solução de problemas ambientais na cidade.

Seguindo a realidade da maioria das cidades brasileiras, também no município de São Carlos as áreas de lazer (praças, centros esportivos, clubes, etc) estão concentradas na região central e em bairros mais elitizados, enquanto a população dos bairros periféricos carece desses espaços. Nesse sentido, 15\% das(os) entrevistadas(os) (sendo 5 homens e 1 mulher) percebem o potencial da área verde da microbacia, que possui várias características - como presença de água, declividade adequada a alguns tipos de esportes radicais, presença de aves, vegetação exuberante em alguns trechos, entre outras - que a tornam apropriada para o lazer, desde que receba o manejo adequado para esse tipo de uso. Entre as propostas para lazer destacam-se a formação de um parque ecológico, praças, ciclovia, campo de futebol e jardim com flores, e estas sugestões partiram, em sua grande maioria, dos homens, possivelmente porque eles convivem muito mais com a área do que as mulheres. Isso pôde ser notado, pois em todas as vezes que estivemos na área verde para o desenvolvimento desse projeto (coletas de água, levantamento das espécies vegetais, levantamento da fauna, visita com estudantes, etc), sempre encontramos pelo menos um homem, e nunca encontramos nenhuma mulher.

A necessidade de uma intervenção educativa junto à população com o objetivo de esclarecer sobre a importância ecológica da área verde e sua influência na qualidade ambiental dos bairros evidencia-se ao constatarmos que 30\% das(os) entrevistadas(os), em sua maioria mulheres, acreditam que a área verde deveria ser totalmente aterrada e substituída por loteamento. Este anseio pela urbanização, possivelmente atrelado às más condições socioeconômicas em que vive grande parte da população da microbacia, foi evidenciado em várias respostas, predominando a proposta de construção de vias de acesso entre os bairros da microbacia, em que $25 \%$ das pessoas entrevistadas (6 mulheres e 4 homens) sugeriram a construção de ruas no interior da área verde e 7,5\% acreditam que uma passarela ligando os bairros resolveria o problema de acesso, destacado principalmente por quem reside no bairro Antenor Garcia, provavelmente por ser o bairro mais periférico da malha urbana. Sem dúvida a situação de carência justifica 
esse tipo de percepção, porém a comunidade também seria vitimada por intervenções que alterassem ainda mais a paisagem natural, como as sugeridas em relação à urbanização da área.

Além disso, tais intervenções estariam em desacordo com a legislação federal, estadual e municipal as quais definem taxas de ocupação, coeficientes de aproveitamento, restrições a atividades de preservação e recuperação da vegetação para áreas de preservação permanente, como é o caso da área verde, devido à presença de nascentes e à declividade de alguns trechos (BRASIL, 1965; BRASIL 1981; BRASIL, 1989; BRASIL, 1998, SÃO PAULO, 1995 e PREFEITURA MUNICIPAL DE SÃO CARLOS, 1996).

$\mathrm{O}$ fato de estas sugestões partirem em sua maioria das mulheres confirma o menor ou nenhum contato de algumas mulheres com a área verde e ainda o sentimento de topofobia percebido em respostas anteriores, principalmente relacionado ao perigo que a área apresenta para as suas crianças e à ligação da área com a violência existente nos bairros adjacentes, servindo de esconderijo para ladrões e para indivíduos ligados ao narcotráfico (usuários e traficantes).

\section{Questão 29: Gostaria de participar de um encontro sobre propostas para recuperação e manutenção da área verde?}

Não obstante $52,5 \%$ das(os) participantes terem afirmado que as decisões sobre o manejo da área verde são de responsabilidade de indivíduos ou instituições (principalmente o poder público municipal) das quais não participam, todas(os) mostraram-se interessadas(os) em participar de encontros sobre a recuperação da qualidade ambiental do bairro e da área verde. Para tanto, faz-se necessária a organização de encontros educativos com a comunidade, para a troca de experiências e conhecimentos, a sensibilização, a mobilização de lideranças e a formação de equipes, visando à construção de uma proposta participativa para o manejo sustentável da área verde. 


\subsubsection{SÍNTESE DA PERCEPÇÃO E SABERES LOCAIS DA COMUNIDADE EM RELAÇÃO À ÁREA VERDE}

Após o levantamento do perfil das pessoas entrevistadas, foi possível concluir que $70 \%$ são migrantes, dos quais $32,5 \%$ vêm de outros estados trazendo, portanto, culturas e experiências diversas e lembranças de lugares distantes do passado, com paisagens naturais e belas, o que provavelmente exerceu influência quanto à topofilia em relação à área verde, que de alguma forma reporta a lugares significativos do passado.

Quanto à faixa etária e tempo de residência na microbacia, os 32,5\% de participantes com mais de 51 anos de idade apresentaram, de modo geral, os mais detalhados comentários sobre a área estudada, até porque na maioria dos casos são as(os) residentes mais antigos do entorno da área verde e que a conheceram e freqüentaram quando (ou desde quando) ainda não estava tão impactada. Essa parcela das(os) respondentes é também a que apresentou menor grau de escolaridade, podendose observar neste caso que o nível de escolaridade não foi responsável por um maior conhecimento sobre esse ecossistema, o que indica que o saber local muitas vezes é construído na própria família ou comunidade, e no contato mais íntimo com o lugar. Esses resultados também apontam que nas escolas este tema (microbacia local, sua dinâmica ambiental e as relações de seus componentes naturais com a comunidade local) talvez não esteja sendo abordado, ou esteja sendo trabalhado de forma insuficiente.

Também em relação às religiões, não foi percebida uma contribuição significativa no que diz respeito à pauta das questões ambientais. Sabendo-se que este é um meio em que se espera que se cultive um clima de confiança (entre os fiéis e para com as lideranças), esperança, união e solidariedade para o enfrentamento de situações negativas, acreditamos que ações de Educação Ambiental junto às lideranças religiosas possam suscitar a inclusão das questões ambientais e a maior motivação da comunidade para a participação na conservação da área verde, uma vez que as orientações das lideranças geralmente são bem vindas e conduzem à reflexão para a mudança de atitudes.

A maioria das pessoas entrevistadas apresentou baixo poder aquisitivo, o que corrobora com a realidade de muitas cidades brasileiras, em que a parte da população mais pauperizada é marginalizada, vendo-se obrigada a ocupar as periferias das cidades, 
geralmente lugares inadequados do ponto de vista da infra-estrutura urbana e ambientalmente frágeis. Interpretamos que a precariedade quanto à moradia e acesso aos serviços urbanos básicos influencia diretamente na percepção dessas pessoas em relação, por exemplo, à percepção quanto à qualidade ambiental de um lugar adequado para se viver, em que predominou a importância dos componentes construídos (todos essenciais como moradia, escola, ruas com asfalto, posto de saúde, e que muitos não possuem). Certamente, a situação de carência também contribuiu para as sugestões em relação ao manejo da área verde, em que algumas pessoas sugeriram a construção de casas populares e de vias de acesso entre os bairros.

Quanto à influência da área verde na qualidade ambiental da microbacia, abordada em outras palavras - "como um bom lugar para se viver" — nas questões 19 e 20, antes de mencionarmos a área verde, somente cinco pessoas comentaram sobre ela, mas ao nos referirmos diretamente àquele local, 77,5\% apontaram que a influência existe, e a maioria aponta como positiva, principalmente devido à beleza da paisagem com ênfase na vegetação. A segunda característica positiva considerada mais importante é o bem-estar físico e mental que a área verde proporciona às pessoas, devido à qualidade do ar e à tranqüilidade do lugar. Já na questão 22 que se referia à influência da existência da área verde na saúde da população do bairro, uma porcentagem ainda maior em relação às duas questões anteriores acredita que a área influencia positivamente, e novamente a melhoria da qualidade do ar é considerada uma contribuição importante. Aqui é também lembrada a existência de plantas medicinais na área verde, cujos conhecimentos pudemos averiguar na questão 22 sobre as espécies vegetais, e novamente aparece a ênfase ao benefício da área para a saúde física e mental (bem-estar e oportunidades de lazer para as crianças).

Por outro lado, pôde ser observado em vários momentos da entrevista, que dentre os elementos considerados negativos segundo a percepção da comunidade, os mais citados e responsáveis inclusive pela topofobia, são os componentes da fauna, principalmente serpentes, roedores e vários invertebrados como o mosquito da dengue, pernilongos, baratas, entre outros. Porém, a maioria das(os) entrevistadas(os) parece compreender que a presença desses animais em suas casas é conseqüência da destruição de seus habitats naturais e/ou da disposição inadequada de resíduos sólidos e efluentes domiciliares na área verde.

Ao comparar as percepções expressadas no decorrer de cada entrevista, percebemos que à medida que respondiam as questões de 19 a 22, iam aprofundando a 
reflexão quanto à importância da área verde para a qualidade ambiental e a sua influência na qualidade de vida. Destarte, constatamos que iniciou-se um processo de sensibilização a partir da participação na própria entrevista, o que avaliamos como positivo.

Apesar da falta de manejo da área verde e da acentuada ocorrência de impactos ambientais, consideramos que essa área foi e ainda é bastante freqüentada pela comunidade local, uma vez que $80 \%$ afirmaram já ter estado na área, e as percepções sobre o local são baseadas em contatos estabelecidos no passado, mas também baseadas na situação ambiental atual da área, pois a maioria esteve lá há menos de um ano. Esse contato com a área em diferentes épocas possibilita às(aos) freqüentadoras(res) acompanhar as modificações do ecossistema decorrentes da interferência antrópica e, através de intervenções educativas, compreender melhor a importância de um manejo sustentável para o local, que desacelere e possa conter o processo de degradação. Nesse sentido, a análise comparativa entre a situação ambiental da área em diferentes épocas pautada nas histórias orais das(os) moradoras(es) mais antigas(os) representam uma importante estratégia para projetos de EA e de planejamento urbano na microbacia.

Interpretamos que esse contato direto de parte da comunidade com a área verde contribuiu para despertar a topofilia baseada na sensibilização para a importância ecológica desse ecossistema e no sentimento de pertencimento através de relações (ainda que muitas vezes utilitaristas) com o lugar (brincar na infância, caçar, lavar roupas, usar como pastagem de animais, entre outros). Para algumas pessoas, o contato com a área criou um sentimento de topofobia, principalmente baseado, como já foi dito, na periculosidade relacionada à presença de animais peçonhentos ou vetores de doenças, à violência e ao relevo acidentado.

A partir das questões 24 e 25 acerca da percepção dos elementos que compõem a área verde, a comunidade destacou a biodiversidade, com 69 espécies animais, das quais praticamente a metade são aves, e algumas com grande potencial como espéciesbandeira.

Consideramos que a percepção da comunidade em relação às espécies da fauna pode ser uma boa referência para o levantamento de espécies da área, pois todas as espécies citadas são características das formações vegetais que compõem a área verde (cerrado e floresta de transição), sendo que muitas foram encontradas durante os levantamentos. Foram mencionadas também 39 espécies vegetais, das quais 10 são conhecidas pelas(os) respondentes como plantas medicinais. Ao comparar com as 
informações da literatura, porém, constatamos que no local há um número muito maior de espécies com propriedades medicinais comprovadas cientificamente, inclusive entre as 39 espécies conhecidas pela comunidade.

Para a maioria das espécies da fauna e para boa parte das espécies vegetais, consideramos pequeno o número de exemplares de cada espécie observados nos levantamentos. Evidentemente essa redução no número de organismos é conseqüência dos impactos ocorridos na área, principalmente a poluição do solo e das águas por resíduos sólidos e efluentes domiciliares, que são os impactos mais percebidos pela comunidade. Outros impactos que comprometem a biodiversidade do local e que também apareceram na percepção são os desmatamentos, as queimadas, as erosões, o assoreamento dos corpos d'água e a caça predatória, todos bastante freqüentes na área verde.

A percepção da paisagem, assim como os nomes atribuídos à área verde pela comunidade basearam-se principalmente em aspectos do relevo, como morro, buracão, barroca, entre outros.

Em relação aos corpos d'água, 49\% da comunidade percebem que é uma área de nascentes e $27 \%$ citam um córrego, mas apenas $8 \%$ referem-se explicitamente ao Córrego da Água Quente. Essa desinformação em relação a esse córrego (homônimo da microbacia) retrata o pouco conhecimento da comunidade em relação às águas da microbacia onde vive. A má qualidade dos corpos d'água verificada nas análises limnológicas é enfatizada pela maioria das(os) participantes, que contrastam o atual estado de poluição das águas com a boa qualidade que no passado possibilitava múltiplos usos (como natação e ingestão). Além disso, destacam as causas da poluição hídrica e sugerem meios para reduzi-la - principalmente através da canalização do esgoto - como uma das principais ações em prol da melhoria da qualidade ambiental da área verde.

De modo geral, pudemos notar que dentre os elementos percebidos, os mais associados à topofilia foram a boa qualidade do ar e a beleza da paisagem com ênfase na vegetação, e a topofobia baseia-se principalmente nos impactos ambientais e na fauna (com ênfase em insetos, roedores e serpentes).

Avaliamos, a partir do estudo da percepção e dos levantamentos in loco que todos esses elementos existentes e percebidos (relevo, biodiversidade que inclui espécies com propriedades medicinais, corpos d'água e a paisagem como um todo), contrastados com os impactos ambientais, retratam o potencial ecológico e paisagístico 
deste ecossistema e constituem importantes temas a serem trabalhados em projetos educativos na comunidade e nas escolas.

De acordo com $45 \%$ das(os) respondentes, a responsabilidade pela atual situação ambiental dos bairros da microbacia e da área verde é de terceiros, representados principalmente pelo poder público municipal. E um número ainda maior $(52,5 \%)$ entende que as decisões sobre o manejo da área verde também são de responsabilidade de agentes externos. Esses números atestam que a população já incorporou a sua exclusão nos processos decisórios, corroborando com a histórica ausência de participação daquelas(es) que são as(os) mais atingidas(os) pelas intervenções decorrentes do processo.

No caso da MCAQ, procuramos entender os motivos que justificam a falta de participação popular no manejo da área verde, e destacamos alguns que consideramos principais:

- são relativamente recentes os projetos ambientais de cunho participativo que vêm sendo desenvolvidos na microbacia;

- apesar da divulgação em boletins específicos distribuídos nos bairros (entre outros veículos de comunicação) e dos convites pessoais, a maioria das(os) entrevistadas(os) afirmaram que não participam destes projetos porque não têm acesso às informações. Isso pode significar que, como a maioria da comunidade não participa de Associação de Bairro, as lideranças comunitárias não conseguem dialogar com a maioria das(os) moradoras(es);

- a população não é mobilizada e não está habituada a se organizar para reivindicações junto ao poder público;

- parte da comunidade sabe que um grande trecho da área verde é de propriedade particular e se sente incapaz de atuar, atribuindo a responsabilidade pelo manejo aos proprietários;

- a comunidade está ciente de que na área verde ocorrem ações ligadas ao tráfico de drogas e outros tipos de práticas ilícitas e que por isso o local é vigiado, sentindo-se incapaz de mudar essa realidade.

Nesse sentido, esse trabalho pode fornecer subsídios para outros projetos que visem a mobilização da comunidade local e para a criação de instrumentos de organização dessa comunidade, de modo que se fortaleça e possa ser informada e ouvida em seus anseios e propostas, através da organização de encontros educativos, visitas monitoradas à área verde, levantamento dos projetos desenvolvidos na 
microbacia, fóruns de debate, entre outras possibilidades que possam vir a ser vislumbradas. 


\subsection{PERCEPÇÃO AMBIENTAL DE ESTUDANTES DO ENSINO MÉDIO DE TRÊS ESCOLAS ESTADUAIS INSERIDAS NA MICROBACIA DO CÓRREGO DA ÁGUA QUENTE EM RELAÇÃO À ÁREA VERDE DA MICROBACIA}

A análise da percepção ambiental com ênfase nas relações de topofilia e topofobia de estudantes em relação à área verde da MCAQ baseou-se nos resultados da aplicação de um mapa mental e um questionário no total de 06 questões. Nesse levantamento, foi anunciada oralmente uma questão de cada vez, a começar pelo mapa mental, e seguindo a ordem das cinco questões restantes. Somente quando as(os) participantes terminavam uma questão, lhes era anunciada a próxima. Desse modo, durante a aplicação do mapa mental (questão 01) até a questão 03, não mencionamos que estávamos nos referindo à área verde da microbacia, de modo a não induzir as respostas às primeiras perguntas. A partir da questão 04, todas(os) sabiam a respeito de que local estávamos perguntando. Para a interpretação dos dados de topofilia e topofobia e valorização da paisagem, consideramos o conjunto de questões, ao invés de considerar cada resposta a uma questão específica, e destacamos algumas das respostas que melhor exemplificam a percepção desse público.

Após a interpretação dos resultados de cada escola, foi realizada uma análise comparativa entre as percepções das três turmas de estudantes, aqui apresentada. É importante ressaltar que algumas(uns) participantes da EE Aracy Pereira Lopes já haviam tratado deste tema e visitado essa área verde com a professora de Geografia. Por outro lado, as(os) estudantes das outras duas escolas não haviam participado de nenhuma visita monitorada à área verde, sendo que somente algumas pessoas já haviam ido até o local por conta própria. Porém, a mesma professora também leciona na EE Orlando Perez e já havia conversado com as(os) estudantes sobre a área verde em sala de aula. Quanto à turma da EE Maria Ramos, esta contou que nenhum(a) professor(a) a havia levado ao local.

Após o levantamento da percepção das(os) estudantes, foram desenvolvidas atividades de intervenção educativa nas escolas EE Orlando Perez e EE Maria Ramos, sendo possível avaliar os resultados destas. 


\subsubsection{PERFIL DAS(OS) PARTICIPANTES}

Todas(os) as(os) participantes eram estudantes da terceira série do Ensino Médio do período noturno, sendo 18 estudantes da EE Aracy Pereira Lopes, 24 da EE Orlando Perez e 24 da EE Maria Ramos, cujas distribuições por gênero, faixa etária e bairro onde residem encontram-se na Figura 52 e no Quadro 21:

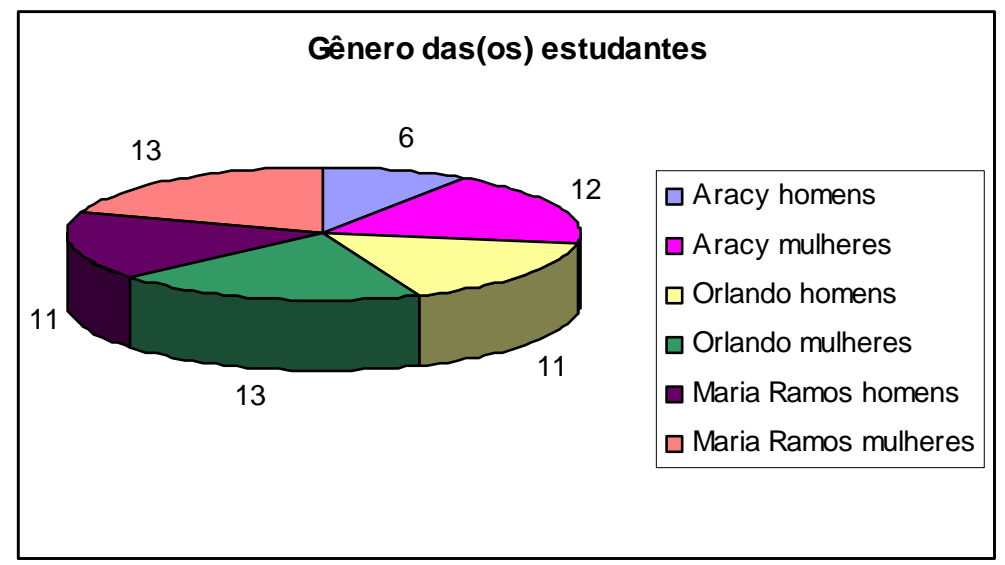

Figura 52: Distribuição das(os) estudantes por escola e por gênero.

\begin{tabular}{|c|c|l|}
\hline Escolas & Intervalo de Faixa Etária & \multicolumn{1}{|c|}{ Bairros onde residem } \\
\hline EE Aracy PereiraLopes & 17 e 22 anos & $\begin{array}{l}\text { Cidade Aracy I e II, Monte } \\
\text { Carlo, Antenor Garcia e Jd. } \\
\text { Cruzeiro do Sul }\end{array}$ \\
\hline EE Orlando Perez & 16 e 20 anos & Cidade Aracy I e II \\
\hline EE Maria Ramos & 16 e 34 anos & $\begin{array}{l}\text { Cidade Aracy I e II, Jd. Cruzeiro } \\
\text { do Sul, Vila Prado, Vila Santa } \\
\text { Isabel, Jd. Belvedere, Boa Vista, } \\
\text { Bela Vista, Botafogo, Jd. } \\
\text { Pacaembu, Jd. Itamarati e Jd. } \\
\text { Beatriz }\end{array}$ \\
\hline
\end{tabular}

Quadro 21: Distribuição das(os) estudantes por faixa etária e bairros onde residem

A seguir, apresentamos uma análise comparativa entre a percepção ambiental das três turmas de estudantes em relação à área verde da microbacia, a partir de cada questão. 


\subsubsection{PERCEPÇÃO AMBIENTAL E TOPOFILIA DAS(OS) ESTUDANTES EM RELAÇÃO À ÁREA VERDE}

\section{Questão 01: Observando o mapa mental, descreva o que existe no espaço vazio entre os bairros.}

Para a análise dos resultados dos mapas mentais (cujo modelo encontra-se no Anexo 3), os componentes citados foram agrupados em tabelas (Anexo 16) nas seguintes categorias: relevo ou topografia, solo e rochas, água, vegetação, fauna, componentes construídos, resíduos sólidos, erosões e outros.

De modo geral, as(os) estudantes da EE Aracy Pereira Lopes e da EE Orlando Perez conhecem com detalhes a área verde, citando vários de seus elementos mais significativos. Todavia, é possível supor, por causa do detalhamento das respostas das estudantes da EE Maria Ramos, que das 13 pessoas que afirmaram já ter visitado a área verde na questão 03 (sobre visitação à área), somente três estudantes já freqüentaram ou freqüentam a área verde, a ponto de a conhecerem mais detalhadamente.

Em relação aos componentes da área verde com base no mapa mental, a vegetação foi o mais percebido pelo público das três escolas, sendo citada por $89 \%$ das(os) respondentes da EE Aracy Pereira Lopes (como matagal, mata, mato, área verde, árvores, árvores frutíferas, frutos, flores e plantas medicinais), por 83\% das(os) respondentes da EE Orlando Perez (como vegetação, matas, mato, verde e pastos) e por todas as pessoas da EE Maria Ramos (como descampado com grama ou pastagem, vegetação, árvores, mata nativa, e principalmente como mato). Porém, em um encontro posterior explicaram que na verdade para elas(es) mato é sinônimo de mata, ou formação vegetal nativa, como cerrado e mata ciliar.

Elementos que compõem o relevo da área verde e que a população utiliza para dar nome ao local também foram lembrados por $100 \%$ das(os) respondentes da EE Maria Ramos com base no mapa mental, variando entre buraco, buracão, cratera, barroca, barrancos, baixada, vale, morro e serra, sendo que os nomes predominantes foram buracão e barroca, exatamente os 2 dois mais comuns entre a comunidade dos bairros próximos à EE Maria Ramos (Jardim Pacaembu e Jardim Gonzaga). Na EE Aracy Pereira Lopes as palavras vale e morro destacaram-se entre os elementos do relevo, nomes mais comumente dados à área verde pelas(os) moradoras(es) dos bairros Cidade Aracy e Antenor Garcia, uma vez que a maioria das(os) participantes da EE Aracy Pereira Lopes reside nesses dois bairros. Na EE Orlando Perez, o termo 
relacionado ao relevo mais representativo foi morro, o que pode ser explicado pela relação topográfica entre a área verde os bairros Cidade Aracy I e II (onde essas(es) estudantes residem e estudam), uma vez que esses bairros situam-se na parte mais baixa da microbacia.

O segundo componente mais citado nas escolas EE Aracy Pereira Lopes e EE Orlando Perez foram os corpos d'água, com 30 citações na EE Aracy Pereira Lopes e destaque para nascentes e minas e para córrego da Água Quente, ambos citados por 7 pessoas.

Lima (2003) desenvolveu um estudo da percepção ambiental da população da área urbana de São Carlos, residentes portanto na bacia hidrográfica do rio do Monjolinho. $\mathrm{O}$ autor constatou que somente $32,5 \%$ das pessoas entrevistadas apresentavam algum conhecimento sobre bacia hidrográfica, e somente $10 \%$ imaginavam a qual bacia pertence São Carlos. Isso mostra que esse não é um conceito apreendido pelas pessoas em geral. Também em relação aos corpos d'água, o autor constatou pequena percepção, sendo que em um universo de 40 pessoas, somente uma citou o córrego da Água Quente.

Em nossa pesquisa, o número de vezes em que aparece o córrego da Água Quente e outros detalhes específicos sobre os corpos d'água nas respostas pode ser porque algumas(uns) dessas(es) participantes estiveram na área verde com a professora de Geografia, conheceram algumas nascentes e receberam explicações a respeito, tendo sido falado inclusive a respeito do aqüífero Guarani (segundo informação da professora), que aparece em uma das respostas. Na EE Orlando Perez, os corpos d'água tiveram 19 citações, e destaque para córrego, citado por $42 \%$ das pessoas, das quais a metade especificou o córrego da Água Quente, possivelmente porque este assunto fora trabalhado em sala de aula. Na EE Maria Ramos, os corpos d'água foram citados 17 vezes, com destaque para rio de esgoto ou esgoto, citados por 6 pessoas e córrego, por 7 pessoas, sendo que apenas 2 referiram-se especificamente ao córrego da Água Quente. Consideramos que foi bastante baixa a percepção em relação ao córrego da Água Quente, uma vez que, além de dar nome à microbacia, estava demarcado e denominado no mapa mental, o que revela a ruptura da convivência entre parte das pessoas mais jovens da microbacia e o corpo d'água que dá nome à mesma. Boa parte da juventude da microbacia atravessa a área verde, mas pensa que a água lá existente é proveniente apenas de esgoto doméstico. 
Um contraste de percepção interessante entre o público das três escolas foi em relação à fauna. As(os) estudantes das EE Maria Ramos e EE Orlando Perez citaram uma pequena diversidade de espécies animais, e apenas animais como cobras, aranhas, ratos e baratas, todos considerados pela maioria da população como prejudiciais à saúde por serem perigosos, peçonhentos ou vetores de doenças, sendo inclusive um dos elementos responsáveis pela topofobia de muitas pessoas em relação à área verde. No entanto, as(os) estudantes da EE Aracy Pereira Lopes, única turma que já tivera uma aula de campo na área verde, fizeram 27 referências à fauna, citando 12 diferentes espécies, entre insetos (abelhas e pernilongos), aracnídeos (aranhas e carrapatos), escorpião, peixes, sapos, lagartos, cobras (falsa coral, cobra-cega), pássaros e mamíferos (gambás, tatus, coelhos e morcegos). Esse contraste revela a importância da realização de atividades fora da sala de aula para aumentar o conhecimento, por exemplo, sobre a biodiversidade de ecossistemas naturais, o que pode ser um passo importante para a sensibilização quanto à importância da conservação das espécies e do ambiente como um todo.

A temática da fauna e da flora na educação escolar foi estudada por Pegoraro em escolas da região de Campinas, cujos resultados confirmam que o cotidiano urbano e o processo de escolarização propiciam mais o contato e o aprendizado a partir de ambientes antropizados, de paisagens artificializadas e do excesso de espécies exóticas, contribuindo para manter em relativo anonimato a rica e diversificada fauna e flora nativas. $\mathrm{O}$ autor apontou também que há limitadas fontes destinadas a intermediar a obtenção de informação e a fomentar a aproximação com os ambientes naturais (PEGORARO, 1998). Esses resultados vêm ressaltar o papel da EA escolar de caráter mais regional, de divulgar e valorizar a proteção às espécies nativas, através da conservação de seus habitats naturais.

O mesmo autor também desenvolveu algumas reflexões sobre o potencial de uma área natural denominada Minipantanal (Americana, SP) como cenário para a EA, e destaca a relevância da EA desenvolvida em ambientes naturais e voltada à percepção e valorização da biodiversidade (PEGORARO, 2004).

Os impactos ambientais relacionados à área demarcada no mapa mental foram a poluição hídrica (nascentes e rios contaminados por esgoto), os resíduos sólidos (lixo, lixo tóxico e entulho) e a erosão. Para as(os) estudantes da EE Orlando Perez e EE Maria Ramos, destacou-se principalmente a poluição hídrica - contaminação do córrego e nascentes, e o esgoto presente em grande parte da área verde - citada por 
$29 \%$ e $42 \%$ respectivamente, e $46 \%$ das(os) estudantes da EE Aracy Pereira Lopes referiram-se predominantemente aos resíduos sólidos, com ênfase para a presença de animais mortos, vistos durante a aula de campo.

Entre todas as respostas, destacamos no quadro 22 aquelas que melhor definem o que existe na área do mapa mental a ser interpretada.

\section{EE Aracy Pereira Lopes}

"Ao redor do Monte Carlo, no lado norte da escola existe o que nós moradores chamamos de buracão ou goiabinha, tem um córrego de água sanitária que passa pelo meio do lugar, pés de goiaba, árvores que conforme a professora disse são árvores com características do cerrado, rochas que dá até pra escalar, existem bastante cobras e até cavernas de morcego. Do lado sul da escola temos também uma grande área verde, com morros e também córregos de água sanitária, inclusive as pessoas que moram no antigo orfanato, algumas casas no fundo já se passam os esgotos, existem apenas animais típicos de lugares assim, como cobra e sapos. Existe também uma areia próxima ao cemitério, onde tem um morro que liga o Monte Carlo à Cidade Aracy, as pessoas caçam tatus e tiram mel de abelhas que existem alojadas em uma pedra, e como não poderia faltar, também passa um córrego de água sanitária. Essa parte é ligada ao que chamamos de vale, por ter muita areia, existem minas e nós até vimos um peixinho, muitas árvores, e lixos espalhados e algumas áreas queimadas, vimos tam'b em uma lebre, e a água limpa da mina se encontrar com a do córrego sanitário, imagine que encontramos lá, até uma vaca morta. Lá existe um vale onde as pessoas bloquearam a água e fizeram um laguinho. Creio que é poluído, é muito grande o lugar e é ao redor da Aracy I. Já na Aracy II, passa o Córrego Água Quente e pelo maio da vegetação também existem minas e até uma área que chamamos de areieiro, onde também existem lagos. Já no Antenor Garcia no começo existe um rio que chamamos de água fria, e tem uma espécie de cachoeira, hoje tem muita areia dentro. Na parte de baixo do Antenor, tem uma área onde se joga entulhos e não tem árvores, já mais no fundo existem as árvores $e$ os córregos e no fundo matos $e$ plantações”.

\section{EE Maria Ramos}

"Entre os bairros Jardim Pacaembu, Jardim Gonzaga, Monte Carlo e Belvedere, existe uma área de mato com uma parte de areia, chamada barroca, tem pássaros e pequenos animais. Entre os bairros da Vila Monte Carlo e Cidade Aracy, existe um pequeno morro de mato e que possui uma pequena trilha que liga o Monte Carlo e a Cidade Aracy. Entre o Mirante da Bela Vista, além dos matos que faz também parte do bairro Pacaembu, existe uma pedreira e alguns lagos”.

Quadro 22: Descrições mais completas sobre a área verde.

\section{Questão 02: O que você observa no trajeto entre sua casa e a escola?}

Essa questão visou investigar se a área verde, situada em local bastante próximo das três escolas e perfeitamente notável, qualquer que seja o trajeto das(os) estudantes até a escola, é um elemento perceptível na observação diária deste público.

A maioria dos alunos da EE Aracy Pereira Lopes vem da parte mais baixa da microbacia, ou seja, dos Bairros Cidade Aracy e Antenor Garcia. Assim, percorrem um trajeto bastante longo até a escola, tendo que subir a serra que separa o bairro Monte 
Carlo (onde se localiza a escola) dos bairros onde residem.A partir dos resultados da observação dos participantes no trajeto para a escola, pode-se perceber que, talvez porque $44 \%$ já visitaram a área verde pelo menos uma vez, e porque a maioria mora distante da escola, vários componentes naturais da área foram percebidos (26 citações), como as árvores ou vegetação do morro, o córrego da Água Quente, o solo arenoso e o relevo que indica a percepção da paisagem como um todo (morro, serra). Esse público também percebe os impactos ambientais como erosões, queimadas na vegetação, presença de esgoto e lixo, e a paisagem degradada. Apesar de serem, dentre as três escolas, a turma que percebe a área verde e seus componentes com maior detalhamento, os elementos observados com maior freqüência ainda são os componentes construídos e mais próximos das pessoas, como equipamentos públicos e estabelecimentos comerciais. Em relação à turma da EE Orlando Perez, pode-se perceber que, ainda que a maioria já tenha visitado a área verde pelo menos uma vez, somente uma pessoa cita o morro como elemento da paisagem (que certamente pode ser avistado por todas(os) pela sua amplitude e proximidade tanto do bairro quanto da escola, e que representa a área verde da microbacia). Todas as demais respostas referem-se apenas aos componentes construídos ou a componentes naturais que compõem a infra-estrutura do bairro, como árvores urbanas, flores e plantações. Embora a área verde seja o componente mais extenso da paisagem da microbacia e parte da turma de estudantes da EE Maria Ramos já tenha ido até a área, como explicam nas respostas à questão sobre o mapa mental, o elemento que mais aparece em sua percepção são as casas, citadas por 71\%. Além das casas, foi citado um grande número de estabelecimentos comerciais e equipamentos públicos como escola, creche e caixa d'água do SAAE. A área verde (vegetação, árvores) foi citada por $46 \%$ das pessoas (menos da metade das(os) participantes), o que mostra que a área verde é significativa para elas, mas que no cotidiano voltam mais o olhar para os componentes construídos e mais próximos. Interpretamos que o fato dessas três turmas estudarem no período noturno, horário em que a área verde se destaca menos, pode ter influenciado na percepção, uma vez que realmente a escuridão dificulta o contato visual com esse local.

\section{Questão 03: Existe alguma vegetação em seu bairro? Você já visitou?}

Essa questão visou analisar, além do conhecimento e percepção em relação à área verde, também o sentimento de pertencimento das(os) estudantes, por entendermos 
que o fato de considerarem a área verde como parte de "seu bairro", está relacionado com a noção de co-responsabilidade na sua recuperação e proteção. Abaixo, apresentamos as tabelas 5, 6 e 7 com a distribuição das(os) estudantes dos diferentes bairros e escolas, sua percepção em relação à existência de área verde próxima ao bairro e a quantidade de pessoas que já visitaram esse local.

Tabela 5: Percepção das(os) estudantes da EE Aracy Pereira Lopes sobre a existência e o sentimento de pertencimento em relação à área verde da microbacia adjacente aos bairros em que residem.

\begin{tabular}{|l|}
\hline $\begin{array}{l}\text { EXISTE ALGUMA VEGETAÇÃO EM SEU BAIRRO? } \\
\text { Bairros onde residem: Monte Carlo, Cidade Aracy I e II, Antenor Garcia, Jardim } \\
\text { Cruzeiro do Sul }\end{array}$ \\
\hline \multicolumn{1}{|c|}{$\begin{array}{c}\text { Percepção das(os) estudantes de cada } \\
\text { bairro }\end{array}$} \\
\hline $\begin{array}{l}\text { Sim (Monte Carlo, Cidade Aracy I e II, } \\
\text { Antenor Garcia, Jardim Cruzeiro do Sul, }\end{array}$ \\
\hline SE EXISTE, VOCÊ JÁ VISITOU? \\
\hline $\begin{array}{l}\text { Sim (Cidade Aracy I e II, Jardim Cruzeiro } \\
\text { do Sul, Monte Carlo, Antenor Garcia, }\end{array}$ \\
\hline $\begin{array}{l}\text { Não (Monte Carlo, Cidade Aracy II, } \\
\text { Antenor Garcia, }\end{array}$ \\
\hline $\begin{array}{l}\text { Não responderam (Antenor Garcia, Cidade } \\
\text { Aracy II, }\end{array}$ \\
\hline
\end{tabular}

Tabela 6: Percepção das(os) estudantes da EE Orlando Perez sobre a existência e o sentimento de pertencimento em relação à área verde da microbacia adjacente aos bairros em que residem.

EXISTE ALGUMA VEGETAÇÃO EM SEU BAIRRO?

Bairros onde residem: Cidade Aracy I e II

\begin{tabular}{|l|c|}
\hline \multicolumn{1}{|c|}{$\begin{array}{c}\text { Percepção das(os) estudantes de cada } \\
\text { bairro }\end{array}$} & Número de citações \\
\hline Sim (Cidade Aracy I e II) & 21 \\
\hline Não sei (Cidade Aracy I e II) & 3 \\
\hline SE EXISTE, VOCÊ JÁ VISITOU? & 12 \\
\hline Sim (Cidade Aracy I e II) & 7 \\
\hline Não (Cidade Aracy I e II) & 2 \\
\hline Não responderam (Cidade Aracy I) &
\end{tabular}

Tabela 7: Percepção das(os) estudantes da EE Maria Ramos sobre a existência e o sentimento de pertencimento em relação à área verde da microbacia adjacente aos bairros em que residem.

\begin{tabular}{|l|l|}
\hline EXISTE ALGUMA VEGETAÇÃO EM SEU BAIRRO? \\
\hline Percepção das(os) estudantes e bairros onde residem & $\begin{array}{l}\text { Número de } \\
\text { citações }\end{array}$ \\
\hline $\begin{array}{l}\text { Sim (Pacaembu, Boa Vista, Jd. Beatriz, Jd. Cruzeiro do Sul, Cidade } \\
\text { Aracy, Jd. Itamaraty, Jd. Belvedere, Vila Isabel, Botafogo, Jd. Beatriz) }\end{array}$ & 19 \\
\hline $\begin{array}{l}\text { Não (Jd. Cruzeiro do Sul, Pacaembu, Bela Vista, Boa Vista, Vila } \\
\text { Prado) }\end{array}$ & 5 \\
\hline SE EXISTE, VOCÊ JÁ VISITOU? & 13 \\
\hline Sim & 3 \\
\hline Não & 2 \\
\hline Não responderam & \multicolumn{2}{|l|}{} \\
\hline
\end{tabular}


Somente na EE Aracy Pereira Lopes, $100 \%$ da turma afirmou existir área verde em seu bairro e apenas 33\% referiram-se explicitamente à área estudada, cujas respostas estão no anexo 17. Porém, apesar da professora de Geografia já ter realizado uma aula de campo na área verde, somente 44\% afirmaram já ter visitado a área, $28 \%$ nunca foram e $28 \%$ não responderam. Considerando-se que a área verde é adjacente aos bairros onde todas(os) residem, e que 100\% sabem da existência da área verde, é relativamente alta a porcentagem de pessoas que nunca a visitou (55\%). Esta ruptura do contato com a natureza pode estar relacionada com o estilo de vida urbana atual, em que os espaços naturais estão se tornando cada vez mais escassos por conta da degradação, e que a rotina da vida humana está cada vez mais concentrada no ambiente construído, até porque há um intenso movimento da grande mídia que serve à elite detentora dos meios de produção, de distanciar o ser humano da vida simples em contato com o natural, para engrená-lo na ideologia do consumo como forma de alcançar a felicidade. Concordamos com MMA/IDEC (2002), que é muito difícil não ser afetado por essa publicidade massiva do consumo, que se incorporou a todos os aspectos de nossa vida e nos emite mensagens o tempo todo, de forma direta ou velada, e acrescentamos que a juventude é uma das principais destinatárias dessa publicidade.

Nesse sentido, as intervenções educativas que se pretendem transformadoras dessa realidade, se deparam com um grande desafio, o de resgatar o valor do ser em detrimento do tão supervalorizado ter, e o resgate dos benefícios da vida em contato mais íntimo com a natureza.

A grande maioria $(87,5 \%)$ da turma da EE Orlando Perez afirmou existir área verde em seu bairro e 50\% já a visitaram, mas somente 37,5\% referiram-se especificamente à área verde estudada, cujas respostas estão no anexo 17. É interessante observar que ninguém afirmou não existir área verde adjacente ao bairro, mas 3 pessoas responderam "não sei", o que demonstra profunda ruptura com os elementos naturais da paisagem onde vivem, uma vez que a área verde é bastante extensa, fazendo limite com toda a face norte do bairro Cidade Aracy e é totalmente evidente.

Uma grande porcentagem (79\%) de estudantes da EE Maria Ramos afirmou existir área verde em seu bairro e 54\% disseram que já visitaram esse local, mas somente $33 \%$ referiram-se à área verde estudada, cujas respostas estão anexo 17. É interessante observar que entre estudantes do mesmo bairro houve percepções diferentes, o que mostra que a percepção da paisagem baseia-se também em fatores 
individuais (utilização dos cinco sentidos, experiências do passado, entre outros, conforme Tuan, 1983).

Nas respostas à questão 03, as(os) respondentes utilizaram diferentes nomes para a área verde mencionada, que compõem a tabela 8.

Tabela 8: Nomes atribuídos à área verde próxima à escola e número de citações em cada escola.

\begin{tabular}{|l|c|c|c|}
\hline $\begin{array}{c}\text { Nomes atribuídos à } \\
\text { verde }\end{array}$ & $\begin{array}{c}\text { EE Aracy Pereira } \\
\text { Lopes }\end{array}$ & EE Orlando Perez & EE Maria Ramos \\
\hline Vale & 4 & 6 & - \\
\hline Buracão & 2 & - & 1 \\
\hline Vegetação & - & 3 & 5 \\
\hline Mata & - & 4 & - \\
\hline Morro & - & 1 & - \\
\hline Matagal & - & - & 1 \\
\hline Barroca & - & - & 1 \\
\hline Cafezal Água & - & - & - \\
\hline $\begin{array}{l}\text { Córrego da Auente } \\
\text { Quenta }\end{array}$ & - & 2 & - \\
\hline Água Fria & 2 & 1 & 2 \\
\hline Bicão, Parque do Bicão & - & - & \\
\hline
\end{tabular}

O nome mais utilizado pelas(os) participantes da EE Aracy Pereira Lopes e EE Orlando Perez para se referir à área verde da microbacia é vale, provavelmente pela topografia do trecho da área verde mais próxima aos bairros onde moram (predominantemente Cidade Aracy e Antenor Garcia), onde há grande extensão de profundas ravinas e voçorocas. A turma da EE Maria Ramos talvez seja a que menos conhece a área verde (lembrando que das 24 pessoas, somente 19 afirmaram que existe área verde próxima ao bairro e só 08 deixaram claro que estavam se referindo à área verde deste estudo). Portanto, o nome mais utilizado por essa última turma foi vegetação que, para quem observa essa paisagem ao longe, é o elemento mais facilmente notável.

\section{Questão 04: O que você já viu ou imagina que exista na área verde próxima ao bairro em que está inserida sua escola?}

Essa questão visou analisar a percepção das(os) estudantes a partir de uma reflexão mais aprofundada e direcionada à área verde da microbacia, pois antes de fazer a pergunta, deixamos claro a que local estávamos nos referindo. A partir das respostas à questão 04, dividimos os elementos citados nas seguintes categorias: componentes 
naturais (vegetação, fauna, água, solo e rochas, e relevo), componentes construídos, impactos ambientais e pessoas.

Dentre os componentes naturais, tanto na EE Aracy Pereira Lopes quanto na EE Orlando Perez, a fauna foi o elemento mais lembrado, com 33 citações e indicação de 16 espécies de animais (entre insetos, aracnídeos, peixes, sapo, cobras, aves e 7 espécies de mamíferos) na primeira escola, e 13 citações e 7 espécies de animais (lagarto, aves e mamíferos) na segunda escola. Nessas duas escolas, a vegetação foi o segundo item mais lembrado entre os componentes naturais com 14 citações na EE Aracy Pereira Lopes e 12 citações na EE Orlando Perez.

Na EE Maria Ramos, por sua vez, a vegetação foi o componente mais percebido (citado principalmente como árvores frutíferas), confirmando a suposição apresentada na análise da questão 03 sobre os nomes atribuídos à área (vegetação é o nome mais freqüentemente atribuído à área verde pelas(os) estudantes da EE Maria Ramos).

Comparando os resultados das três escolas, consideramos que os corpos d'água apareceram poucas vezes nas respostas (em 39\% na EE Aracy Pereira Lopes, em 33\% na EE Orlando Perez e em 17\% na EE Maria Ramos), e o Córrego da Água Quente quase não faz parte da percepção destas(es) jovens, sendo citado por apenas 3 pessoas. Esses resultados demonstram que falta informação a este público, pois a microbacia é amplamente recortada por regiões de nascentes, que formam o Córrego da Água Quente, homônimo da mesma, e mesmo assim muitas(os) moradoras(es) não sabem de sua existência. Essa ausência de percepção em relação ao elemento água está relacionada ao grau de impactação das nascentes e do próprio córrego, que muitos confundem com "um rio puramente de esgoto", o que pode contribuir ainda mais para a ausência de preocupação com a continuidade da degradação destes corpos d'água (retirada da mata ciliar, assoreamento e despejo de efluentes domésticos e industriais).

Com exceção dos corpos d'água, consideramos que houve um grau de detalhamento significativo nas descrições dos componentes naturais da área verde pelas(os) estudantes das EE Aracy Pereira Lopes e EE Orlando Perez, o que demonstra a importância do estudo do ambiente utilizando a bacia hidrográfica como unidade de estudo, sendo que o mesmo não foi observado para os estudantes da EE Maria Ramos.

Quanto aos componentes construídos, na EE Aracy Pereira Lopes foram citados o cemitério, as trilhas de pessoas, as cercas e as torres de energia, todos inseridos na área verde. Na EE Orlando Perez foram citados as fazendas e chácaras, os terrenos baldios dos bairros e a pista de motocross, sendo que somente esta última está inserida 
na área verde. E na EE Maria Ramos, foram citados o Bicão e o Bairro Jardim Gonzaga, ambos que não compõem essa área verde.

Todos os elementos e o número de vezes que apareceram nas respostas estão apresentados no anexo 18.

\section{Questão 05: Quem são (as)os responsáveis pela atual situação da área verde existente próximo à sua escola, e quem deve decidir o que deveria ser feito naquele local?}

A primeira parte dessa questão teve como objetivo analisar a noção de coresponsabilidade das(os) estudantes em relação à atual qualidade ambiental da área verde. A segunda parte visou analisar a noção da importância da participação da comunidade local para opinar sobre as decisões que dizem respeito à qualidade ambiental da área verde da microbacia onde vivem e que, direta ou indiretamente, influenciam a qualidade de suas vidas. A seguir, apresentamos as tabelas 9 e 10 referentes aos resultados para as três escolas.

5) Primeira parte: Quem são as(os) responsáveis pela atual situação ambiental da área verde?

Tabela 9: Pessoas ou instituições responsáveis pela atual qualidade ambiental da área verde da microbacia do córrego da Água Quente, segundo a percepção das(os) estudantes.

\begin{tabular}{|l|c|c|c|}
\hline \multirow{2}{*}{ Responsáveis pela área verde } & \multicolumn{3}{|c|}{ Número de citações em cada escola } \\
\cline { 2 - 4 } & $\begin{array}{c}\text { EE Aracy } \\
\text { Pereira } \\
\text { Lopes }\end{array}$ & $\begin{array}{c}\text { EE Orlando } \\
\text { Perez }\end{array}$ & $\begin{array}{c}\text { EE Maria } \\
\text { Ramos }\end{array}$ \\
\hline $\begin{array}{l}\text { (Poder público) Prefeito, prefeitura, } \\
\text { governantes da cidade }\end{array}$ & 5 & 8 & 9 \\
\hline Prefeitura e moradoras(es) locais & 3 & 2 & 1 \\
\hline Moradoras(es) & 6 & 5 & 8 \\
\hline Secretaria do Meio Ambiente & 1 & & 1 \\
\hline Donos dos terrenos & - & 2 & 1 \\
\hline Não responderam & 3 & & 4 \\
\hline Ninguém & - & 1 & \\
\hline Responderam "não sei” & - & 6 & \\
\hline
\end{tabular}

De acordo com a tabela anterior, a turma da EE Aracy Pereira Lopes considera a comunidade da microbacia como a principal responsável pela atual qualidade ambiental da área verde, conforme indicado por $33 \%$ das(os) respondentes, reconhecendo-se, portanto, como responsáveis, enquanto $17 \%$ dividem a co-responsabilidade com o poder 
público municipal. Na EE Orlando Perez e na EE Maria Ramos, o poder público foi o responsável indicado com maior freqüência $(33 \%$ e $37 \%$ das respostas, respectivamente). Uma porcentagem significativa de estudantes da EE Orlando Perez não sabe ou não respondeu (25\%) quem é o responsável, enquanto $21 \%$ dessa escola entendem que essa responsabilidade é da comunidade local e apenas 2 pessoas acreditam que são responsáveis a prefeitura e a comunidade. Na EE Maria Ramos, 33\% conferiram essa responsabilidade exclusivamente à comunidade, apenas uma pessoa dividiu essa gestão entre o poder público municipal e a comunidade local, uma pessoa disse que ninguém é responsável e 4 pessoas ignoravam os responsáveis. Portanto, de acordo com a tabela 9 , pode-se perceber que nessa última escola, 9 estudantes sentem-se co-responsáveis pela área verde, enquanto outros 15 delegam essa responsabilidade a terceiros.

Na cidade de São Paulo, Jacobi (2000b) também estudou a percepção ambiental das pessoas de três bairros de diferentes padrões socioeconômicos, e observou que $88 \%$ delas escolheram a ação governamental como o nível mais adequado de ação para enfrentar os problemas ambientais da cidade. No entanto, somente as(os) moradoras(es) da periferia destacam a importância da mudança de atitude da população, principalmente em relação à disposição de lixo nos córregos. O autor considera que essa ênfase da população da periferia está diretamente associada ao impacto que este fato provoca nas suas vidas, notadamente na época das enchentes.

5) Segunda parte: Quem deve decidir o que deve ser feito na área verde?

Tabela 10: Pessoas ou instituições responsáveis pelas decisões sobre o manejo da área verde da microbacia do Córrego da Água Quente, segundo a percepção das(os) estudantes.

\begin{tabular}{|c|c|c|c|}
\hline \multirow{2}{*}{$\begin{array}{c}\text { Responsáveis pelas decisões sobre } \\
\text { manejo }\end{array}$} & \multicolumn{3}{|c|}{ Número de citações em cada escola } \\
\hline & $\begin{array}{c}\text { EE Aracy Pereira } \\
\text { Lopes } \\
\end{array}$ & $\begin{array}{c}\text { EE Orlando } \\
\text { Perez }\end{array}$ & $\begin{array}{c}\text { EE Maria } \\
\text { Ramos }\end{array}$ \\
\hline $\begin{array}{l}\text { Nós, o povo, moradores, a } \\
\text { comunidade }\end{array}$ & 7 & 13 & 6 \\
\hline Prefeitura e moradores & 3 & 2 & 5 \\
\hline $\begin{array}{l}\text { Poder público (Prefeito, prefeitura, } \\
\text { SMA, governantes da cidade) }\end{array}$ & 3 & 1 & 7 \\
\hline Juventude & 1 & - & - \\
\hline Ambientalistas & 1 & - & - \\
\hline Donos do terreno & - & 2 & - \\
\hline Representante do bairro & - & 1 & - \\
\hline Especialistas & - & - & 1 \\
\hline Moradores e especialistas & - & - & 2 \\
\hline Responderam “não sei” & - & 1 & - \\
\hline Não responderam & 3 & 3 & 3 \\
\hline
\end{tabular}


Ao opinar acerca de quem deve decidir sobre o manejo da área verde, na EE Aracy Pereira Lopes 39\% afirmaram ser exclusivamente a comunidade local e 17\% acreditam em uma parceria com o poder público. No total, 56\% demonstraram que desejam participar das decisões sobre o manejo da área verde. As pessoas restantes delegaram a responsabilidade pelo local à juventude, ao poder público ou a ambientalistas, enquanto 3 pessoas não souberam responder.

Na EE Orlando Perez, por sua vez, 54\% afirmaram ser a comunidade local que deve decidir, se incluindo, portanto, nessa categoria. Somente duas pessoas afirmaram que essa responsabilidade deve ser dividida entre a prefeitura e a comunidade local, e as demais atribuíram a responsabilidade aos possíveis donos dos terrenos, poder público municipal e representante de bairro, eximindo-se de participar de qualquer decisão a esse respeito.

No que se refere aos responsáveis por decidir o que deve ser feito na área verde, 13 estudantes da EE Maria Ramos incluíram a comunidade local, afirmando que esta deve decidir sozinha (25\%) ou participar das decisões que envolvam a área verde, juntamente com a prefeitura $(21 \%)$ ou com especialistas, como entidades ou algum profissional de meio ambiente (8\%). Finalmente, 33\% delegam essa responsabilidade a terceiros (poder público ou especialista) e 3 pessoas não souberam responder.

Concluímos, de acordo com a percepção desse público, que das(os) 66 participantes, $38 \%$ entendem que a comunidade é total ou parcialmente responsável pela atual situação ambiental da área verde, ou seja, tem participado do processo de degradação desse local, enquanto $42 \%$ atribuem essa responsabilidade exclusivamente a terceiros e $20 \%$ não souberam (ou não quiseram) responder.

Em contraste com os resultados da primeira parte da questão 05 , ao responder acerca das decisões sobre o manejo da área, 57\% incluíram a comunidade entre os responsáveis por essas decisões. Essa afirmação denota um sentimento de pertencimento e um desejo de se engajar nas decisões concernentes à área verde.

Embora entre essas(es) estudantes tenha sido explicitado o interesse em participar dos processos decisórios em relação às questões ambientais locais, sabe-se que na realidade essa participação popular não ocorre. Em relação à gestão dos corpos d'água, por exemplo, Lima (2003) verificou que 92,5\% das pessoas entrevistadas na cidade de São Carlos, nunca ouviram falar em Comitês de Bacia Hidrográfica (CBH) (apesar de São Carlos fazer parte de dois), 100\% não se sentem representados junto aos $\mathrm{CBH}$, e $67 \%$ demonstraram desinteresse em participar. Também percebeu que 
participam bem pouco de eventos relacionados às questões ambientais $(85 \%)$, mas que 90\% consideram esse tipo de atividade importante.

Na realidade, até onde sabemos, somente a partir da gestão passada (2000-2003), o governo municipal começou a voltar o olhar para a microbacia do córrego da Água Quente, para a realização de melhorias concretas nos bairros e de uma parte da área verde, adjacente aos bairros Jardim Gonzaga e Monte Carlo (Projeto Habitar BrasilBID). Até então, não houvera nenhuma mobilização nem do governo municipal para, juntamente com a comunidade da microbacia, pensar um manejo sustentável para a área verde estudada. Além disso, também é possível supor que a falta de lideranças comunitárias e a falta de democracia nas relações entre o poder público municipal e a comunidade (que somente a partir do mandato passado tornaram-se mais próximos), sustentaram uma cultura de não-participação. O desejo de participar nas decisões sobre a sua microbacia foi expresso por mais da metade das(os) respondentes da MCAQ, mas a histórica ausência desse exercício de cidadania pode ter feito com que somente 15\% compreendam a importância do diálogo entre população e poder público municipal.

\subsubsection{TOPOFILIA E TOPOFOBIA DAS(OS) ESTUDANTES EM RELAÇÃO À ÁREA VERDE DA MICROBACIA}

Questão 6: Conte o que a área verde próxima ao seu bairro e/ou à sua escola significa para você e o que você gostaria que fosse feito naquele local.

$\mathrm{Na}$ primeira parte dessa questão, procuramos entender que tipo de relações (topofilia ou topofobia) cada estudante estabeleceu com a área verde, e as frases dos quadros 23,24 e 25 são a síntese das respostas de cada pessoa.

Questão 6: Primeira parte: O que a área significa ? 


\begin{tabular}{|l|}
\hline SÍNTESES QUE INDICAM TOPOFILIA \\
\hline Local de ar puro, paisagem agradável e descanso \\
\hline Um lugar inspirador e fundamental em nossas vidas \\
\hline Significa minha vida, porque podemos respirar um ar mais puro \\
\hline Um local muito significativo porque adoro verde e água \\
\hline Local que não deve ser modificado \\
\hline Bem-estar visual, respiratório \\
\hline Bom lugar para se morar perto \\
\hline Importante para o controle do meio ambiente, vegetação preservada \\
\hline Área para ser olhada, admirada. \\
\hline Área de recarga do Aqüífero Guarani \\
\hline Área importante para os animais e a população \\
\hline Lugar inspirador para desenhar \\
\hline Uma reserva maravilhosa, mas mal cuidada. \\
\hline \\
\hline SíNTESES QUE INDICAM TOPOFOBIA \\
\hline Área com lixo, água suja e mal cheiro \\
\hline Lugar em que a vegetação está sendo destruída \\
\hline Lugar com rio muito poluído, cheio de arranha-gato e cobras. \\
\hline Quadro 23: Interpretação do significado da área verde para as(os) estudantes da EE A
\end{tabular}

Quadro 23: Interpretação do significado da área verde para as(os) estudantes da EE Aracy

Pereira Lopes, quanto às relações de topofilia/topofobia.

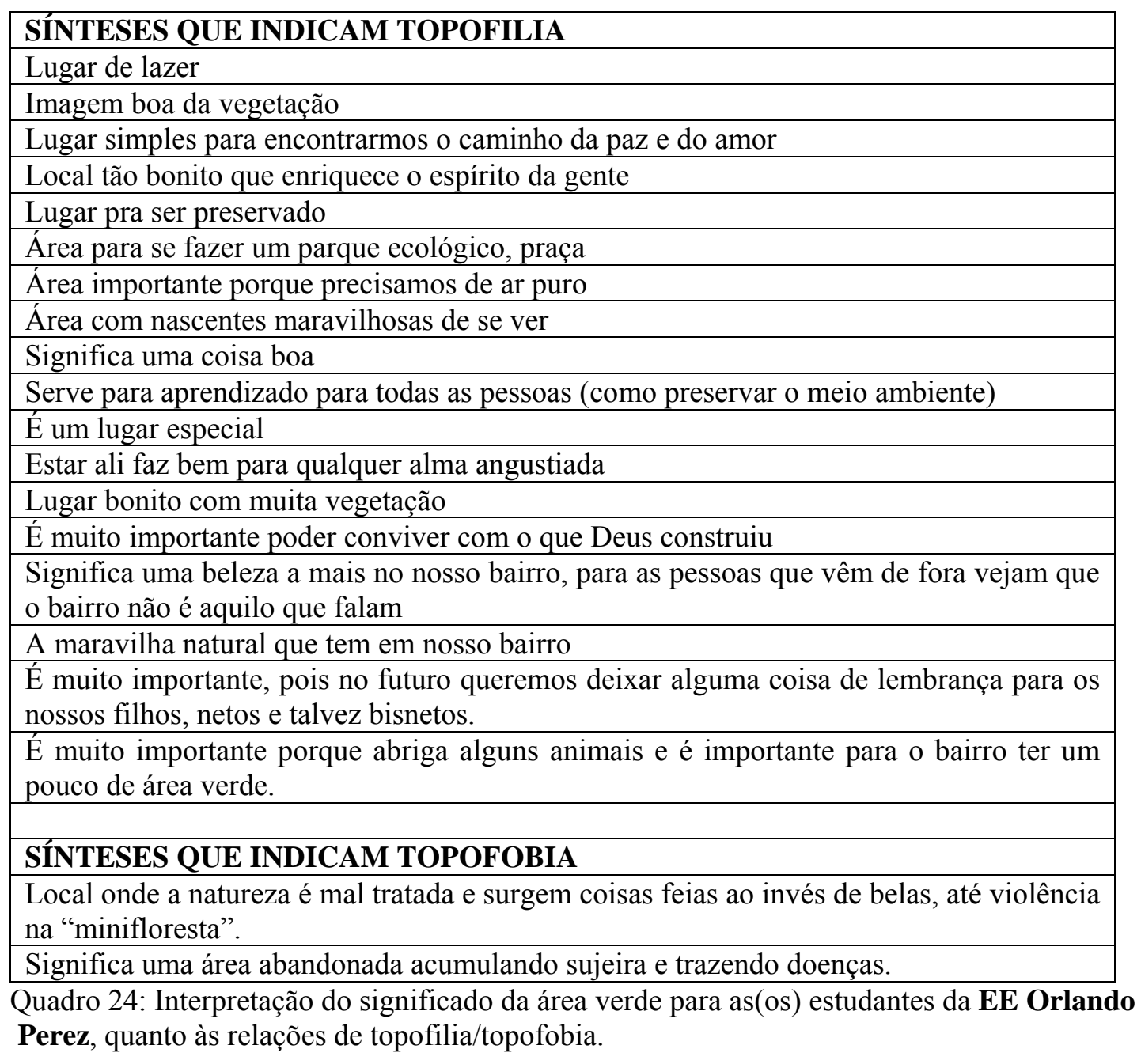




\begin{tabular}{|l|}
\hline O QUE A ÁREA SIGNIFICA ? \\
\hline SÍNTESES QUE INDICAM TOPOFILIA \\
\hline Saúde para a comunidade \\
\hline Local belo e importante para a vida, para melhorar o ar \\
\hline Grande patrimônio \\
\hline Área importante por causa da vegetação - 2 \\
\hline Lugar de divertimento \\
\hline Lugar diferente e belo \\
\hline O grande buraco verde \\
\hline Local belo, que dá prazer e recorda a infância \\
\hline Mata nativa \\
\hline \\
\hline SÍNTESES QUE INDICAM TOPOFOBIA \\
\hline Área de risco \\
\hline Lugar escuro, que causa medo \\
\hline Lugar perigoso \\
\hline Área pouco aproveitada \\
\hline Área mal cuidada -2 \\
\hline \\
\hline Não respondeu -1 \\
\hline
\end{tabular}

Quadro 25: Interpretação do significado da área verde para as(os) estudantes da EE Maria Ramos, quanto às relações de topofilia/topofobia.

De acordo com os quadros supracitados, que contêm o significado da área verde para cada pessoa, interpretamos que a maioria das(os) participantes (62\%) das três escolas, possui topofilia para com esse ecossistema. Essas relações topofilicas justificam-se por diferentes percepções, as quais dividimos em 3 categorias: 1) consciência ambiental (incluindo a preocupação com o bem-estar da comunidade, que também compõe o ambiente local), em que algumas pessoas enfatizam a importância ecológica da área como recarga do aqüífero Guarani, importante pelas nascentes, ou por proporcionar a melhoria da qualidade do ar da microbacia e a conservação das espécies animais e vegetais (inclusive plantas medicinais), demonstrando que compreendem algumas das funções ambientais desse ecossistema e se preocupam com a sua degradação; 2) valorização estética e contemplação, que pertence às pessoas que consideram essa paisagem bela e inspiradora, tanto que contribui para o relaxamento, a busca de sentimentos positivos e a valorização estética dos bairros adjacentes; 3) sentimento de pertencimento em relação ao lugar (no passado elou presente), por aquelas(es) que utilizam (ou utilizaram na infância) o local como área de lazer, para brincadeiras, colheita de frutos, contato com as águas, demonstrando grande sentimento 
de pertencimento, pois referem-se à área verde como um local íntimo, divertido, como se fosse o "seu quintal".

Segundo Salcedo (2001) a idade é uma variável que influencia a percepção, havendo diferenças significantes entre os adultos e os jovens. Em pesquisa realizada junto às(aos) moradoras(es) de Jardim (MS), Marin (2003) identificou a água como um dos principais elementos do ambiente que inspiram topofilia, à qual chama de hidrofilia. Em nosso estudo, observamos que a maioria das(dos) moradoras(es) mais antigas(os) da microbacia expressaram hidrofilia em relação ao córrego da Água Quente e suas nascentes, destacando a água como um elemento importante para a constituição da paisagem e para sua valorização estética.

Porém, entre as(os) mais jovens, muito embora estivessem voltando a reflexão para uma área de mananciais, a água não constituiu um elemento significativo na determinação da topofilia. $O$ fato da juventude da microbacia não ter conhecido os corpos d'água antes de se tornarem impactados, provavelmente influenciou para a existência desse contraste na percepção. Para este público o elemento mais representativo quanto à topofilia é a beleza da paisagem com ênfase na vegetação.

Um número bem mais reduzido de participantes (15\%) apresentou topofobia, indicando a área verde como um espaço de degradação da vegetação, poluição das águas e do solo, transmissão de doenças, com animais peçonhentos, e freqüentado por indivíduos ligados a algum tipo de violência. Realmente esse ecossistema possui todas essas características que, para essas pessoas, se sobrepuseram ao que tem de belo, agradável e ecologicamente relevante. Acreditamos que através de projetos de EA que sejam capazes de mostrar todas as maravilhas existentes na área verde, esse sentimento negativo possa ser substituído por um desejo de contribuir para a recuperação ambiental do local, revertendo essa situação inspiradora de topofobia. Comparando os resultados das três escolas, percebemos que a topofobia em relação à área verde apareceu com maior freqüência na EE Maria Ramos, talvez porque muitos não haviam visitado a área verde nem tratado desse assunto na escola.

Analisando as respostas a todas as perguntas, destacamos abaixo (quadro 26) alguns depoimentos que demonstram relações topofílicas e topofóbicas com a área verde. 


\section{TOPOFILIA}

\section{EE Aracy Pereira Lopes}

"É muito importante ter uma área de vegetação próxima à sua casa, para que possamos olhar, admirar, estar nessa área e acho que essa área deveria ser preservada e cuidada por todos”.

"A área de vegetação significa muito pra mim porque nós moradores dessa região do Monte Carlo, Cidade Aracy e Antenor Garcia que estamos mais próximo de que podemos nos recarrega o nosso aqüífero Guarani”.

"A área de vegetação é muito importante para a natureza, como os animais que vivem na mata e para a própria população que vive ao redor da areia da vegetação”.

"Uma reserva maravilhosa, mas não cuidada, um sentimento bonito. Mal ajudado pelos moradores. Algo que todos deveriam preservar. Devemos fazer uma conscientização, pois o que no futuro sobrará disso do presente? Deveria fazer uma área de preservação ambiental, com animais que tem seu habitat lá, um córrego com bastante água cristalina. Plantar mais árvores para que no futuro possam ser algo importante".

“Tem uma mata, que por vista é muito bonita, dá para respirar um pouco de ar puro, sentir o cheirinho de mato de terra”.

\section{EE Orlando Perez}

"Aqui no bairro em que moro é uma das coisas que mais tem vegetação, existem muitas matas em volta do bairro, uma vez saí com minha mãe e algumas pessoas para ver, e vi muitas flores e árvores bonitas na mata que fica bem próxima à minha casa”.

“O "vale” é um local cheio de natureza. (“daria até para ser parque ecológico”) se fosse cuidado. Eu já visitei várias vezes”.

"Existe uma mata, sempre dou uma volta por dentro dela, e é muito bonito, há uns anos atrás nós vamos caçar, e era super divertido”.

"A área significa um lugar de lazer onde devemos ter a honra de estar nela para nos distrairmos ou se divertindo, mas como aqui não é nada disso só fica na imaginação, para que possamos ter uma imagem boa da vegetação é preciso que ela seja limpa, bem cuidada, tendo novidades a cada momento, preservada por nós, sendo como uma floresta ou um simples lugar que talvez não seja tão simples, mas que seja um lugar pra nós encontrarmos o caminho da paz e do amor”.

“Às vezes eu pensava que (a área verde) não servia para nada, mas agora eu caí na real, e pensei se não servisse para nada ela não estaria ali. Quando a gente olha pelo lado de fora, e só vê árvores estranhas e verdes a gente pensa pra quê isso? Mas a partir do dia em que conheci o interior daquele local e vi o quanto era bonito passei a pensar, pode não servir para fazer a gente ficar rico materialmente, mas só de olhar enriquece o espírito da gente em ver tanta beleza reunida em um só lugar. Eu acho que nada deve ser feito pelo homem naquele lugar, a única coisa que o homem deve fazer é preservá-lo".

"Significa muita coisa, aliás eu adoro um verde, para mim é um lugar especial. Estar ali faz bem para qualquer alma angustiada, adoro morar nessa cidade, aprendi a conviver com as pessoas e respeitar a cidade do meu coração. A minha amada Cidade Aracy está dentro de mim há 10 anos, não consigo viver sem esse lugar. Fui viajar uma vez para São Paulo a saudade foi tanta que agüentei ficar apenas 13 dias. Foi a maior felicidade rever meu lindo Bairro novamente. Vou ser sincera apesar de ter várias pessoas que não prestam, fumam maconha, crack, cheiram cocaína, mas com essas pessoas não tenho problema, pois não faço descriminação de pessoa, o importante é me respeitar. E com 10 anos de Aracy, aprendi a gostar de todos igual a minha área é o Córrego da Água Quente e gostaria que preservasse esse lugar, não deixasse cortar nenhuma árvore, e que esse esgoto que passa a céu aberto, fosse água limpa, potável. E nascesse como nasce da nascente. E quero ver a minha cidade cada vez mais bela. É como sempre sonhei". 
"Como a minha rua é finita, após o terreno dela existe uma vegetação imensa. Eu já fui lá milhares de vezes, lá é muito bom tem grutas, árvores frutíferas e minas”.

"Pra começar é um lugar muito bonito, mas o perigo é muito porque há lixo por toda parte e gostaria muito que ali se transformasse em uma área natural para passeios, esportes e diversão porque quanto mais melhorar, melhor é a nossa vida irá ser quanto mais tivermos verdes próximos a nós mais bem nos faz".

"A área perto da minha casa é a barroca, e acho que é uma área pouco aproveitada, pois poderia existir uma maior preservação, sendo assim uma área que poderia ser de reserva ambiental. O que está faltando é a falta de iniciativa por parte dos moradores e da própria prefeitura. Poderia ser uma área onde pudesse haver lazer, segurança, um parque ambiental onde pudéssemos ter orgulho por morar perto desta área de vegetação".

"O grande buraco verde: este grande buraco verde é chamado de barroca. Ele significa não só para mim, mas para muitas pessoas que podemos ter o que muita população não tem, o oxigênio puro da natureza. Gostaria que este local se transformasse num grande parque natural, com muita vegetação, plantas, flores e animais e rios limpos. Onde as pessoas poderiam passear e até passar um fim de semana com sua família. Eu acho que se o homem tem a capacidade de destruir a natureza, ele também tem a capacidade de dar vida a ela. Basta querer".

"A área de vegetação próxima ao meu bairro significa muita para mim. Ao contrário do que dizem lá não é um local tão sujo como parece, pois contém lugares prazerosos de se freqüentar. Em certos pontos em que eu tive a audácia de ir é tão lindo que chega até emocionar. Parte da minha infância eu passei lá pois como minha família era humilde a minha única diversão e dos meus amigos era percorrer a barroca para desfrutar de tudo maravilhoso que ela pode oferecer. O meu maior sonho seria que lá fosse preservado e utilizado como fonte de lazer, proporcionando bem estar à população".

\section{TOPOFOBIA OU INDIFERENÇA}

\section{EE Aracy Pereira Lopes}

"O rio que fica ali perto é muito poluído, a mata é cheia de arranha-gato e cheia de cobras".

"Bastante mato, rio fedorento".

"É um lugar de muita vegetação e está sendo destruída. Não me sinto bem porque a vegetação está se acabando em São Carlos e no Brasil inteiro".

\section{EE Orlando Perez}

"Perto de casa tem uma vegetação e lá é uma mata totalmente fechada e eu nunca visitei e não pretendo ir visitar".

\section{EE Maria Ramos}

"Essa área pode ser aproveitada é muito bem. Poderiam fazer tratamento na água, pois atualmente é conhecido como um córrego de água suja. O buracão tem área de grande risco onde tem casas que podem desmoronar, por causa do desnível do chão. Se essa área fosse cuidada, nós teríamos uma imagem muito melhor desse local".

"Não digo bem vegetação mas tem um matagal perto da pedreira lá do bairro. E eu não visitei e nem pretendo".

"Existe, mas com o tempo realmente está virando bairro, é muito bonito, um lugar gostaria de ficar, mas é perigoso porque há lixo e traficantes andando próximo de nós”.

“É um buraco muito grande, cheio de barrancos, onde passa um rio de água suja”.

"Não posso dizer ao certo o que contém, mas acho pelo que pouco observo que tem muitos barrancos com lixo, ou às vezes águas poluídas, enfim são áreas espaçosas que deveriam ser utilizadas em 
benefício da cidade. Mas resumindo pelo pouco que vi, acho que só tem lixo, terra e água suja”.

“Neste local existe um buraco enorme com muito mato, bichos, aranhas, cobras e outros”.

"Bom, nesses espaços vazios onde todos nós estamos vendo, eu acho que tem muitas coisas, nas ruas tem muitos buracos, muitos lixos tóxicos, em alguns lugares matos, entulhos, muitos canos estourados e esgotos".

"No final do Mirante da boa vista começa um grande barranco cheio de mato, lixo. Quase no começo do Antenor Garcia tem um rio de esgoto, mais um pouco de mato e depois começa o Antenor Garcia. Do Mirante da boa vista até o Jardim Gonzaga tem bairros, não sei se tudo é a favela, mas sei que tem uma parte que é a favela que não tinha nem tratamento de esgoto".

"Acredito que na sua maioria haja muito mato e um grande acúmulo de lixo, sendo uma grande baixada".

Quadro 26: Algumas respostas que indicam sentimento de topofilia/topofobia pela área verde.

Questão 6: Segunda parte - Sugestões preliminares para a elaboração da proposta de manejo.

As sugestões para manejo da área verde contidas na tabela 11 foram consideradas preliminares, uma vez que ainda não havíamos realizado com as(os) estudantes, o encontro educativo sobre a área verde, sendo que este posteriormente aconteceu somente com as turmas da EE Orlando Perez e da EE Maria Ramos.

Tabela 11: Sugestões preliminares das(os) estudantes das 3 escolas para o manejo sustentável da área verde da microbacia do córrego da Água Quente.

\begin{tabular}{|l|c|c|c|}
\hline \multicolumn{1}{|c|}{ Sugestões } & $\begin{array}{c}\text { EE Aracy } \\
\text { Pereira Lopes }\end{array}$ & $\begin{array}{c}\text { EE Orlando } \\
\text { Perez }\end{array}$ & $\begin{array}{c}\text { EE Maria } \\
\text { Ramos }\end{array}$ \\
\hline Preservação & 5 & 9 & 4 \\
\hline $\begin{array}{l}\text { Recuperação e preservação da vegetação, não } \\
\text { desmatar, Plantio de árvores e plantas, Evitar } \\
\text { queimadas }\end{array}$ & 3 & 6 & - \\
\hline $\begin{array}{l}\text { Impedir o uso para pastagem de animais } \\
\text { domésticos }\end{array}$ & 1 & - & - \\
\hline Não jogar lixo, entulho & & & 4 \\
\hline $\begin{array}{l}\text { Limpeza do rio, das águas, tratamento da água, } \\
\text { rio bem cuidado, despoluição do córrego, não } \\
\text { poluir mais o Água Quente }\end{array}$ & 2 & 2 & - \\
\hline Canalização, tratamento do esgoto & & & - \\
\hline Conservação dos animais & 2 & 1 & - \\
\hline Não poder levar comida & 1 & - & 1 \\
\hline $\begin{array}{l}\text { Conscientização da população através de } \\
\text { palestras e visitas às casas }\end{array}$ & 1 & - & - \\
\hline Mais respeito e cuidado para com a área & 3 & 1 & - \\
\hline Guarda-florestal & 3 & - & - \\
\hline Área de lazer & 1 & - & - \\
\hline Praça & 2 & 1 & - \\
\hline Colocar bancos & 1 & - & \\
\hline $\begin{array}{l}\text { Decreto proibindo novos loteamentos ou } \\
\text { ocupações }\end{array}$ & 1 & & - \\
\hline
\end{tabular}




\begin{tabular}{|l|c|c|c|}
\hline Deixar como está & 1 & - & 1 \\
\hline $\begin{array}{l}\text { Limpeza geral, despoluição, recuperação do } \\
\text { ambiente }\end{array}$ & - & 2 & 3 \\
\hline $\begin{array}{l}\text { Parque ecológico, bosque, reserva ecológica, } \\
\text { parque ambiental, reserva natural }\end{array}$ & - & 4 & 2 \\
\hline Local turístico & - & 1 & - \\
\hline Trilha na mata & - & 1 & - \\
\hline Evitar poluição de nascentes & - & 2 & - \\
\hline Divulgação sobre a mata & - & 1 & - \\
\hline Retirada do lixo & - & - & 2 \\
\hline Prevenção de poluição & - & - & 1 \\
\hline Área de visitação & - & - & 1 \\
\hline Área de educação e lazer & - & - & 1 \\
\hline Área para esportes & - & - & 1 \\
\hline Plantação de flores & - & - & 1 \\
\hline Construção de casas populares & - & - & 1 \\
\hline Construção de ruas ligando os bairros & - & - & 1 \\
\hline Não respondeu & - & - & \\
\hline
\end{tabular}

A topofilia predominante nesse público em relação à área verde justifica as sugestões para manejo da área, a maioria delas voltada para a sua recuperação e conservação. Entre as propostas, destacam-se a preocupação com a preservação da área, com 5 citações na EE Aracy Pereira Lopes, 9 na EE Orlando Perez e 4 na EE Maria Ramos, com idéias como não jogar lixo ou entulho, limpeza do córrego da Água Quente, das nascentes, recuperação da vegetação, plantio de árvores, fim do desmatamento e das queimadas, conservação dos animais, fiscalização e criação de um parque ambiental, entre outras.

Mais do que atestar a degradação, as(os) participantes enfatizaram ao longo das respostas sua preferência pela recuperação, com ênfase para as nascentes e o córrego. Em seu estudo sobre a percepção da população de Uberlândia/MG em relação a dois córregos da cidade, Silveira e Colesanti (2001) igualmente concluíram que apesar da maioria das pessoas ter uma percepção negativa dos córregos quanto ao caráter estético, devido aos impactos ocorridos nos mesmos, estas consideram a sua existência e recuperação importantes. Ou seja, além do seu papel ecológico como fator limitante da vida, a água é um elemento de considerável importância e agradabilidade na composição das paisagens, ainda que se pense somente no caráter estético.

As palavras respeito e cuidado merecem destaque, pois apesar de aparecerem somente em 11 respostas, denotam uma relação fortemente topofílica com a área verde, o que nos leva a perceber a importância dessa área para alguns membros dessa comunidade como o "seu lugar". A detecção dessas pessoas e a sua motivação através de intervenções educativas, pode representar uma boa oportunidade para suscitar o 
surgimento de novas lideranças comunitárias entre a juventude, voltadas à conservação ambiental. Também é importante destacar as idéias de divulgação sobre a área verde e de conscientização da população sobre a importância desse ecossistema através de palestras e visitas às casas da microbacia, e o desejo de que receba infra-estrutura para ser utilizada como espaço ecoturístico.

De acordo com as respostas acima, a área verde atende à população de diferentes bairros, que possui variados sentimentos em relação à área. Não foi possível observar padrões de topofilia ou topofobia das pessoas de diferentes bairros em relação à área verde. Esses sentimentos parecem ser resultado do grau de convivência e conhecimento da área, sendo observada maior topofilia nas pessoas que começaram a conviver com a área verde ainda na infância. Em relação às propostas de manejo, quase todas nos pareceram coerentes e de possível inclusão em um plano de manejo sustentável, exceto a proposta de "deixar a área como está", que ignora a presença de acentuados impactos ambientais, e aquelas que apontaram a utilização para construção de moradias ou ruas, o que degradaria ainda mais o local, destruindo o que resta da biodiversidade e de nascentes.

Valorização da área verde, segundo as 10 categorias de Meinig para a valorização da paisagem

Outra análise em relação à percepção da paisagem da área verde como um todo, realizada a partir da análise de todas as respostas, foi em relação às 10 categorias propostas por Meinig (1979), citado por Cabral e Buss (2001), sendo possível encontrar em várias respostas, aspectos que as enquadrariam em mais de uma categoria. Todavia, procuramos em cada resposta os pontos que nos pareceram mais salientados, de modo que cada resposta se enquadrasse mais fortemente em uma categoria apenas. Abaixo relacionamos as categorias de Meinig e algumas falas que se enquadram em cada categoria:

\section{CATEGORIAS E FALAS INCLUÍDAS EM CADA CATEGORIA:}

Observação: Existem algumas categorias que não coincidiram com nenhuma resposta (categorias 1,5 e 6 ).

\section{1 - Paisagem como natureza (elementos físicos);}




\section{2 - Paisagem como habitat (território para morada humana);}

\section{EE Maria Ramos}

"É um espaço enorme que, na minha opinião, devia ser utilizado para outros fins, como construir uma área residencial”.

"Aquilo só confirma o descaso da prefeitura em relação aos moradores vizinhos daquele local. Aquela é uma área grande, mas muito mal cuidada, é um local muito utilizado por ligar bairros a outros. Deveria ser feito um projeto para a construção de novas ruas, ser feita uma limpeza em alguns pontos”.

\section{3 - Paisagem como sistema (visão de conjunto);}

\section{EE Aracy Pereira Lopes}

"Importante para o controle do meio ambiente no meio de tanta poluição; é bom ter lugares assim com vegetação preservada”.

"Uma reserva maravilhosa, mas não cuidada. Deveria fazer uma área de preservação ambiental, com animais que tem seu habitat lá, um córrego com bastante água cristalina. Plantar mais árvores para que no futuro possam ser algo importante".

"A área de vegetação é muito importante para a natureza, como os animais que vivem na mata e para a própria população que vive ao redor da areia da vegetação”.

"A área de vegetação significa muito pra mim porque nós moradores dessa região do Monte Carlo, Cidade Aracy e Antenor Garcia que estamos mais próximo de que podemos nos recarrega o nosso aqǘfero Guarani. Eu gostaria que fosse um tratamento de esgoto para nós não poluirmos as nossas riquezas".

\section{EE Orlando Perez}

"A vegetação próxima ao meu bairro significa uma coisa boa para mim, eu queria que ela fosse cuidada, que as pessoas não jogassem lixo nela, que não poluíssem mais o Córrego da Água Quente”.

"A minha área é o Córrego da Água Quente e gostaria que preservasse esse lugar, não deixasse cortar nenhuma árvore, e que esse esgoto que passa a céu aberto, fosse água limpa, potável. E nascesse como nasce da nascente. E quero ver a minha cidade cada vez mais bela. É como sempre sonhei”.

"Eu gostaria que as pessoas não ficassem maltratando a natureza, gostaria que a população tivesse um pouco de interesse, juízo, não pôr fogo como sempre fazem, não jogar lixo, não poluir os rios, se cada um fizesse sua parte todos seriam beneficiados, porque a natureza é para todos nós, quanto mais nós queimamos, nós estragamos a natureza, mais problemas para a nossa saúde nós vamos ter. E os animais que precisam das árvores, dos rios, para sobreviver, se cada um parar para pensar nisso, seria muito melhor nossa natureza".

"Eu acho que a vegetação perto do nosso bairro é muito importante porque abriga alguns animais e é importante para o bairro ter um pouco de área verde".

\section{EE Maria Ramos}

"Tudo o que existe na natureza é coisa boa e saudável, por isso acho que quanto mais verde existir, melhor. Sou a favor de todos os projetos que incentivem a recuperação da mãe natureza”.

"É importante ter uma vegetação próxima ao local onde se reside ou estuda, deveria se cuidar deste local para se prevenir a poluição do ambiente, para que esta área tenha um futuro, para esta área tenha continuidade e viva".

"A área perto da minha casa é a barroca, e acho que é uma área pouco aproveitada, pois poderia existir uma maior preservação, sendo assim uma área que poderia ser de reserva ambiental”. 
"O grande buraco verde: este grande buraco verde é chamado de barroca. Ele significa não só para mim mas para muitas pessoas que podemos ter o que muita população não tem, o oxigênio puro da natureza. Gostaria que este local se transformasse num grande parque natural, com muita vegetação, plantas, flores e animais e rios limpos. Eu acho que se o homem tem a capacidade de destruir a natureza, ele também tem a capacidade de dar vida a ela. Basta querer”.

"Nós temos em nossas mãos uma das nossas coisas que outros países querem, nossa fauna e nossa flora. Vamos nos conscientizar, é preservando que se mantém”.

“A área verde é muito importante para o ar e a vida. Eu não conheço a área do barranco, mas sei que é um local com árvores e mato, mas só de vista, sei também que é jogado muito lixo e entulho lá, o que prejudica e acaba com o meio ambiente”.

\section{4 - Paisagem como problema (a ser superado);}

\section{EE Aracy Pereira Lopes}

"Gostaria que as pessoas se conscientizassem e não jogassem lixo na área de vegetação. Gostaria também que houvesse algo a fazer no rio, como água suja que joga no rio, não só pelo fato ser suja, tem um mau cheiro danado”.

"Eu gostaria que as pessoas colaborassem e não jogassem lixo na vegetação, porque isso pode causar a poluição e vários tipos de doenças transmissíveis por animais”.

“O rio que fica ali perto é muito poluído, a mata é cheia de arranha-gato e cheia de cobras”.

“Gostaria que fosse sempre bem cuidado. Porque é um lugar de muita vegetação e está sendo destruída. Não me sinto bem porque a vegetação está se acabando”.

\section{EE Orlando Perez}

"No local de vegetação no bairro não é muito bom, não que eu seja pessimista, mas é que infelizmente temos que enxergar o óbvio. A natureza é mal tratada e são poucas as pessoas que se interessam em cultivá-la. Devido a despreocupação de muitas pessoas, vai surgindo coisas feias na natureza que ao invés de ser algo belo, acaba se tornando um estorvo. Onde acaba surgindo até violência na "minifloresta".

"No momento não significa nada para mim porque quase todos estão abandonados e acumulando sujeira e trazendo doença para os moradores".

\section{EE Maria Ramos}

"A imagem dessa área me traz medo, porque se tornou um lugar escuro, que é muito usado por traficantes para fugir da polícia”.

"Infelizmente o local próximo à minha casa que existe vegetação está apresentando riscos à população, o local está servindo para despejo de lixo e entulho, e a medida que o mato cresce, a população sem ter o que fazer bota fogo na vegetação, sem falar no perigo de morte porque não há uma cerca para separar a rua do buraco".

"A vegetação muitas vezes serve para foragidos ficarem acampados. Com isso a população teme visitála, e a vegetação que sofre as conseqüências”.

“Existem áreas de vegetação próximo à minha casa e próximo à minha escola, ela não tem uma importância para mim. Pois é um local de difícil acesso, um lugar perigoso”.

"A área de vegetação do meu bairro não é bem cuidada, pois ainda não existe quem o faça. Muitas pessoas jogam lixo e entulho neste local que era para ser devidamente preservado. Ao longo dos anos esta área está diminuindo, pois o avanço da população sobre estas terras é muito grande. Inclusive vemos casas construídas em lugares impróprios como nos barrancos. Muitas pessoas reclamam dos bichos que aparecem de repente em suas residências, e até já foi visto animais perigosos entrando nas casas como cobras, aranhas, gambás, etc. Sofremos por não seguir uma política de conscientização 
ambiental, se alguém fizesse palestras, visitas às casas, muitas coisas iriam mudar. A informação seria grande estímulo à preservação desta área!!”.

\section{5 - Paisagem como artefato (produto da ação humana);}

\section{6 - Paisagem como riqueza (valor monetário);}

\section{7 - Paisagem como ideologia (representa os símbolos de uma sociedade);}

\section{EE Orlando Perez}

"Eu acho que significa muito, porque ainda poderemos dizer da maravilha natural, que tem em nosso bairro, e acho que tem que ser mais cuidado, mais preservado, para que nunca venha a mudar”.

\section{EE Maria Ramos}

"Conheço pouco o lugar, mas pelo que sei é uma mata nativa e que deve ser preservada. Pelo que eu percebi, essa área já foi maior um dia e que foi sendo desmatada pela expansão da população que foi construindo casas cada vez em locais mais perigosos. Chegaram a esse ponto pela desigualdade social que leva a população cada vez mais à periferia das cidades”.

\section{8 - Paisagem como história (registro de experiências do passado);}

\section{EE Orlando Perez}

"É muito importante, pois no futuro queremos deixar alguma coisa de lembrança para os nossos filhos, netos e talvez bisnetos".

\section{EE Maria Ramos}

"A área de vegetação próxima ao meu bairro significa muita para mim. Ao contrário do que dizem lá não é um local tão sujo como parece, pois contém lugares prazerosos de se freqüentar. Em certos pontos em que eu tive a audácia de ir é tão lindo que chega até emocionar. Parte da minha infância eu passei lá, pois como minha família era humilde a minha única diversão e dos meus amigos era percorrer a barroca para desfrutar de tudo maravilhoso que ela pode oferecer. O meu maior sonho seria que lá fosse preservado e utilizado como fonte de lazer, proporcionando bem estar à população".

\section{9 - Paisagem como lugar (possui valor associado à satisfação de necessidades);}

\section{EE Aracy Pereira Lopes}

"Uma forma e inspiração eu gosto de sentar em cima da laje e olhar o verde, eu gostaria que abrisse, colocar uns bancos, guardas-florestais para a gente sentir mais perto do verde e podermos ver crianças brincando, pássaros cantando, um pouco de mata é fundamental em nossas vidas”.

"Ela significa minha vida, através dela posso respirar um ar mais puro, é responsável pela grande parte de oxigênio do ar, principalmente no meu bairro. Nosso bairro tem um clima excelente, e quando queremos uma sombra e um lugar para passar algumas horas de lazer".

"Ter área de vegetação no local onde moramos é muito importante, pois o ar fica até menos poluído, e também é bom porque podemos visitar, e muitas vezes distrair a cabeça, é outro mundo e me sinto muito bem e gosto de lugares assim, onde tem verde, animais, pois você sai um pouco do seu dia-a dia, onde existe só pessoas, veículos, movimentação no trabalho o dia todo".

"Morar lá é muito bom, pois o ar é mais puro, sem muita poluição. Gostaria que as pessoas tratassem dela com mais respeito, que é um benefício a favor delas”.

"Significa bem estar visual, respiratório". 
"Significa muito para mim, porque eu adoro verde, e água também. Eu gostaria que fosse tratada a água, e o verde cuidado para que todas as pessoas pudessem passear, usar o local como área de divertimento".

\section{EE Orlando Perez}

"A área significa um lugar de lazer onde devemos ter a honra de estar nela para nos distrairmos ou se divertindo, mas como aqui não é nada disso só fica na imaginação, para que possamos ter uma imagem boa da vegetação é preciso que ela seja limpa, bem cuidada, tendo novidades a cada momento, preservada por nós, sendo como uma floresta ou um simples lugar que talvez não seja tão simples, mas que seja um lugar pra nós encontrarmos o caminho da paz e do amor”.

“Ali poderia ser um local turístico, para a família passear”.

“Essa área de vegetação é importante para nós porque nós precisamos de ar puro para viver, e sem essas árvores nós não teríamos ar puro. Sem contar as nascentes que são maravilhosas de se ver. Eu gostaria que houvesse trilha na mata para nós visitarmos e fizessem uma pracinha para que possamos ter uma área de lazer e um ar puro”.

"Nós, moradores do Aracy, queríamos que tivesse uma praça no bairro e no vale seria um lugar apropriado pois tem árvores, um córrego tem bastante vegetação essa obra até ajudaria na preservação do ambiente em que o vale seria bem cuidado e preservado e teríamos uma área de lazer”.

“Nós sobrevivemos dela para limpar e purificar o ar que todos nós respiramos. E gostaria que fosse mais cuidado, e mais preservado pelas pessoas. Pois tem pessoas que apesar de saber a sua importância não faz nada pra preservar o lugar. Por isso que todos nós devemos colocar a mão na consciência, e fazer o máximo possível pra preservar nossa própria vida”.

"Eu gostaria que a prefeitura fizesse algum plano para preservar essas áreas e quem sabe transformar em uma área de lazer para curtir com os amigos e familiares”.

\section{EE Maria Ramos}

"A área deveria ser aproveitada para educação ou lazer, a saúde da comunidade que mora próximo ao local".

“Gostaria muito que ali se transformasse em uma área natural para passeios, esportes e diversão porque quanto mais melhorar, melhor é a nossa vida irá ser quanto mais tivermos verdes próximos a nós mais bem nos faz”.

“Eu gostaria que lá fosse um local mais cuidado, com menos perigo de alguém se machucar, que fosse um local de preservação da natureza, que você pudesse passear entre as árvores, que pudesse respirar ar puro sem perigo algum, com muita tranqüilidade e paz”.

"Acho que ali poderia ser muito bem diferente, menos perigoso, mais bem cuidado com algumas plantações tipo flores, um rio bem cuidado, alguns animais. Acho que se tivesse essa mudança seria bem melhor e com certeza seria muito bem aproveitado pelos moradores. Tipo no Parque ecológico é um lugar gostoso de ir com a família, passear com o filho ou namorado, mas quando você chega lá logo na entrada tem é bonito, quando você entra você respira aquele ar gostoso por causa do contato com a natureza, você se sente muito bem, se sente mais leve e até esquece um pouco dos problemas”.

“A barroca significa para os moradores do bairro Jardim Pacaembu e para mim muito, pois ali é um lugar de divertimento, pois tem um morro de areia que dá para se divertir, e a vegetação possui animais que para quem gosta de observar ali tem".

\section{0 - Paisagem como estética (aspectos artísticos e panorâmicos).}

\section{EE Aracy Pereira Lopes}

"Faz seis anos que moro lá, e com isso sinto uma vontade de preservar tudo isso que faz parte da vida da gente. Às vezes quando quero ter uma inspiração para desenhar olho para baixo de casa e começo a desenhar as árvores mais bonitas”. 
"É muito importante ter uma área de vegetação próxima à sua casa, para que possamos olhar, admirar, estar nessa área e acho que essa área deveria ser preservada e cuidada por todos”.

\section{EE Orlando Perez}

"A partir do dia em que conheci o interior daquele local e vi o quanto era bonito passei a pensar, pode não servir para fazer a gente ficar rico materialmente, mas só de olhar enriquece o espírito da gente em ver tanta beleza reunida em um só lugar”.

"Na minha visão é muito bom ter um lugar assim perto da minha casa, pois em São Paulo, pra onde eu olhava eu via muros de concreto, poluição, pixações, esgotos, favelas, aqui não, aqui eu vejo árvores, lugares bonitos e muita vegetação, pra mim que sou acostumada a ver muros, é muito importante poder conviver com o que Deus construiu e não os homens".

"Ela significa uma beleza a mais no nosso bairro, pois quem vem de fora possa ver um lugar gostoso. E passear e ver que o nosso bairro não é aquilo que as pessoas falam (descriminam-no) e tem uma beleza que todos devem cuidar".

"Eu acho essas áreas muito bonitas porque é bom ter uma vegetação perto da escola e de casa".

\section{EE Maria Ramos}

"Um vale e um matagal ao redor todo florestado. De longe, chega a embelezar a paisagem".

A partir das respostas acima, constatamos que as categorias representadas foram:

- Paisagem como habitat, ou seja, há pessoas que valorizam a área como um local para construção de moradias, desconsiderando todas as funções ambientais desse ecossistema, além da presença de nascentes e da declividade que a tornam inadequada para habitação humana.

- Paisagem como sistema, sendo que estas pessoas compreendem a importância da área verde como ecossistema, e a necessidade de sua recuperação e conservação, para a conservação não apenas da espécie humana, mas de todos os elementos dessa paisagem.

- Paisagem como problema, em que se reconhece esse local como um problema a ser superado, citando algumas das causas desse descontentamento, com ênfase para a poluição das águas, a presença de animais peçonhentos ou vetores de doenças, e por ser freqüentada por pessoas consideradas perigosas.

- Paisagem como ideologia, em que a ocupação e degradação provocadas nessa área são vistas como um símbolo da desigualdade social, obrigando as pessoas mais pauperizadas a ocupar áreas de periferia ecologicamente frágeis. Além disso, essa área contribui para a valorização dos bairros adjacentes, sendo um motivo de honra e orgulho para seus habitantes, que muitas vezes são descriminados devido ao bairro onde residem. 
- Paisagem como história, pois algumas(uns) respondentes possuem uma visão temporal no que diz respeito à área verde, relacionando-a com experiências do passado, principalmente da infância, e preocupando-se com sua recuperação para que as gerações futuras possam conhecê-la e dela desfrutar.

- Paisagem como lugar para a satisfação de necessidades do ser humano, como ter um ar de melhor qualidade, ter uma área para lazer, esporte e educação, que contribua para o bem-estar físico e espiritual das pessoas.

- Paisagem como estética, em que se referem à beleza que essa paisagem proporciona aos bairros circunvizinhos, valorizando-os do ponto de vista estético, merecendo ser admirada e servindo de inspiração para desenhar.

\subsubsection{VISITA À ÁREA VERDE DA MICROBACIA DO CÓRREGO DA ÁGUA QUENTE COM ESTUDANTES E PROFESSORES DA EE ORLANDO PEREZ}

Além do estudo da percepção, foi realizada com as(os) estudantes da EE Orlando Perez e dois professores, uma atividade de intervenção educativa na própria área verde. Essas(es) convidaram também estudantes de outras turmas, familiares e amigos(as) para participar dessa atividade.

Antes de iniciar a visita, as(os) participantes formaram duplas, conversaram e apresentaram a(o) companheira(o) da dupla dizendo porque essa pessoa estava participando da atividade. Muitas(os) comentaram sobre a curiosidade em conhecer a área mais de perto, e outros disseram que queriam matar a saudade dos tempos em que brincavam no local.

Após as apresentações, falamos o objetivo da visita à área, orientamos sobre as instruções para tal atividade e distribuímos recipientes e luvas para a realização de um arrastão ecológico.

Durante essa visita, foi possível mostrar vários elementos interessantes que compõem o ecossistema, descritos abaixo, e tecer alguns comentários sobre cada um deles:

- Ecossistema: as(os) participantes foram orientados sobre as principais características dos ecossistemas cerrado e mata ciliar, como o tipo de solo e as estruturas das espécies vegetais, e puderam contrastar esses dois ecossistemas in loco;

- Biodiversidade: foram encontradas várias espécies de seres vivos, e aproveitamos para falar sobre seus papéis ecológicos naquele ecossistema. Observamos 
fungos decompositores e liquens indicadores de poluição atmosférica. Entre os vegetais, encontramos vários com propriedades medicinais, usados como alimento ou para a confecção de trabalhos manuais, como caraguatá, barbatimão, sucupira, cipó-de-SãoJoão, araticum, mutambo, copaíba, ipê-roxo, olho-de-cabra, sangria-d'água, entre outros (cujos nomes científicos estão descritos no quadro 3, página 98), além de belas flores e alguns frutos. Como representantes da fauna local, foram observados girinos, diversas espécies de aves, fezes de capivara, pegadas de veado catingueiro e inúmeros insetos como borboletas e formigas, e comentamos sobre as interações ecológicas entre os animais e destes com as plantas (esclavagismo, parasitismo, predatismo, competição, polinização e dispersão de sementes).

- Água: as(os) estudantes diferenciaram visualmente e pelo odor a água das nascentes e a água provinda de esgotos domésticos, e aprenderam a coletar alguns dados para a análise da qualidade da água;

- Sensações: todas(os) foram convidados a comparar as sensações (visual, auditiva, olfativa, temperatura, umidade) em relação à área verde e em relação ao ambiente construído, onde iniciamos a atividade (local cimentado, sem vegetação e com insolação direta), e perceberam que o ecossistema natural apresentava muitas vantagens em relação ao ambiente construído, como a beleza da paisagem pelo relevo, pela vegetação diversificada e pelas cores, o clima mais agradável e os sons das aves. Em relação ao odor, disseram que na área verde o cheiro de esgoto estava mais perceptível.

- Impactos ambientais: os mais acentuados e observados foram o assoreamento, as erosões, uma vaca morta causando mal cheiro, e a lagoa e o córrego da Água Quente bastante poluídos por esgoto e resíduos sólidos (na lagoa, principalmente isopor, provalmente usado como bóia pelas(os) freqüentadoras(es);

Contamos nessas atividades com a presença de um biólogo do Centro de Divulgação Científica e Cultural da USP (CDCC), que contribuiu nas explicações sobre os ecossistemas da área, e de um Policial Ambiental, que orientou a turma sobre a legislação ambiental relacionada à área verde.

As(os) participantes ficaram bastante motivadas(os) com a visita à área verde e, para a sensibilização de toda a comunidade escolar, decidiram expor os resultados dessa atividade, inclusive os materiais recicláveis coletados no arrastão ecológico, em uma mostra de conhecimento realizada na escola, para divulgação das atividades e da importância ambiental da área. Também se mostraram interessadas(os) em contribuir com novas propostas para o manejo sustentável da área verde. 
Em 2004, essa parte da pesquisa desenvolvida com a turma da EE Orlando Perez foi apresentada com a co-autoria da professora de Geografia da escola, Roberta Bolzan Simões, no V Fórum Nacional de Educação Ambiental em Goiânia (TÓRO-TONISSI et al., 2004).

Após todas essas atividades, avaliamos que a Educação Ambiental, cujo processo incluiu desde o contato com as(os) educandas(dos) para o estudo da percepção até as atividades educativas in loco, contribuiu para a compreensão da relação entre a existência da área verde e a qualidade ambiental da microbacia, e mostrou que todas(os) têm um papel importante na sua conservação.

\subsubsection{INTERVENCÃO EDUCATIVA NAS ESCOLAS EE ORLANDO PEREZ E EE MARIA RAMOS}

Após o levantamento da percepção ambiental e a visita à área verde com a turma da EE Orlando Perez, realizamos nessas duas escolas mais um encontro de intervenção educativa, conforme descrito nos procedimentos metodológicos, e com o objetivo de obter novas propostas para o manejo da área verde. A seguir foram comparadas as sugestões preliminares de cada escola com as novas sugestões, conforme os quadros 27 e 28 .

\begin{tabular}{|l|l|}
\hline SUGESTÕES PRELIMINARES & \multicolumn{1}{|c|}{ SUGESTÕES ATUAIS } \\
\hline Limpeza geral & a área não deve ser loteada \\
\hline Cuidado e Respeito & o primeiro passo é a desapropriação da área \\
\hline Preservação & tirar o esgoto para que o rio possa voltar a ter vida \\
\hline Parque ecológico, bosque & fazer um mapeamento das árvores \\
\hline Praça & a área deve ser arborizada \\
\hline Local turístico & $\begin{array}{l}\text { fazer o reflorestamento da mata ciliar através de } \\
\text { mutirão para evitar o assoreamento do rio }\end{array}$ \\
\hline Trilha na mata & a área enfeita a entrada do bairro \\
\hline Área de lazer & $\begin{array}{l}\text { conscientizar as crianças divulgando nas escolas, e os } \\
\text { moradores através de panfletos }\end{array}$ \\
\hline Não jogar lixo & as pessoas que conhecem plantas podem ajudar \\
\hline Não desmatar & $\begin{array}{l}\text { cada um colaborar para ajudar a manter, porque a mata } \\
\text { é de todos }\end{array}$ \\
\hline Não poluir mais o Água Quente & fazer um parque ecológico é interessante \\
\hline & montar uma trilha, um zoológico \\
\hline Evitar queimadas & fazer uma pista de saúde \\
\hline Evitar poluição de nascentes & fazer uma pista de motocross \\
\hline Não ter esgoto a céu aberto & $\begin{array}{l}\text { incentivar as pessoas falando bem do lugar e do bem } \\
\text { que esse lugar faz para as pessoas }\end{array}$ \\
\hline Plantio de árvores e plantas & $\begin{array}{l}\text { ter a colaboração de todos (representantes de bairro e } \\
\text { representantes da prefeitura) } \\
\text { daqui a alguns anos vamos precisar dessa água aí }\end{array}$ \\
\hline Divulgação sobre a mata &
\end{tabular}




\begin{tabular}{|l|l|}
\hline Conscientização & $\begin{array}{l}\text { conscientizar as pessoas através de reportagens sobre a } \\
\text { área, para não colocar fogo }\end{array}$ \\
\hline Reserva ecológica & cercar o rio \\
\hline---- & intensificar a educação ambiental dos moradores \\
\hline & acabar com a poluição do rio, tirar o gado \\
\hline & $\begin{array}{l}\text { criar centro de recuperação e de produção de espécies } \\
\text { animais e vegetais nativas }\end{array}$ \\
\hline criar campo de futebol, campo de corrida \\
\hline $\begin{array}{l}\text { puxar bica d'água para uso da população como forma } \\
\text { de lazer }\end{array}$ \\
\hline $\begin{array}{l}\text { instalar lanchonete, sorveteria, quadras de vôlei e } \\
\text { promover a geração de emprego }\end{array}$ \\
\hline $\begin{array}{l}\text { construir pista de ciclismo, quadras de esporte e praças } \\
\text { montar tirolesa, tobogã, toboágua (com ingresso) }\end{array}$ \\
\hline $\begin{array}{l}\text { após tomar todas as providências, divulgar o local } \\
\text { como um lugar turístico para que outras cidades } \\
\text { venham nos visitar }\end{array}$ \\
\hline $\begin{array}{l}\text { construir parquinho para crianças com balanço nas } \\
\text { árvores e gangorras com madeiras não utilizadas. }\end{array}$ \\
\hline
\end{tabular}

Quadro 27: Sugestões das(os) estudantes da EE Orlando Perez para o manejo sutentável da área verde da microbacia do córrego da Água Quente.

\begin{tabular}{|c|c|}
\hline SUGESTÕES PRELIMINARES & SUGESTÕES ATUAIS \\
\hline $\begin{array}{l}\text { Tratamento da água, rio bem cuidado, } \\
\text { despoluição do córrego }\end{array}$ & $\begin{array}{l}\text { conscientizar a comunidade sobre a importância do } \\
\text { Córrego da Água Quente e de sua vegetação através de } \\
\text { palestras educativas, cartazes, panfletos explicativos, para } \\
\text { que não seja mais poluído }\end{array}$ \\
\hline Retirada do lixo & recolher todo lixo e entulho que poluem o lugar \\
\hline $\begin{array}{l}\text { Despoluição, recuperação do ambiente, } \\
\text { limpeza }\end{array}$ & $\begin{array}{l}\text { manter essa área como área de preservação natural aberta } \\
\text { para pesquisas }\end{array}$ \\
\hline Prevenção de poluição & combater a poluição do Córrego em toda área abrangida \\
\hline Área de visitação & $\begin{array}{l}\text { reunir voluntários para manutenção e conservação do } \\
\text { futuro "parque" }\end{array}$ \\
\hline Área de educação e lazer & $\begin{array}{l}\text { realizar mutirões conscientizando a não poluir e fazer } \\
\text { uma proposta ao prefeito incentivando o plantio de } \\
\text { árvores na cidade e matas nativas }\end{array}$ \\
\hline Área de lazer & $\begin{array}{l}\text { fundar uma ONG dos moradores da região para discutir } \\
\text { sobre as áreas naturais do bairro }\end{array}$ \\
\hline Área para esportes & $\begin{array}{l}\text { criação de um parque aberto à população, com uma } \\
\text { iluminação para as pessoas poderem fazer visitas } \\
\text { noturnas como na "Pista de Saúde", sendo que a } \\
\text { iluminação deve ser estratégica para não interferir na } \\
\text { fauna local }\end{array}$ \\
\hline Plantação de flores & $\begin{array}{l}\text { para a manutenção da ordem e da segurança do local, } \\
\text { empregar pessoas que vigiem em período integral essa } \\
\text { área }\end{array}$ \\
\hline Preservação da área & $\begin{array}{l}\text { implantação de programas para serem feitos no parque } \\
\text { como atividades físicas (alongamentos, ginástica), } \\
\text { passeios monitorados, etc }\end{array}$ \\
\hline Parque ambiental, reserva natural & $\begin{array}{l}\text { distribuição de panfletos com papel reciclado para a } \\
\text { conscientização da população }\end{array}$ \\
\hline $\begin{array}{l}\text { Conscientização ambiental com palestras e } \\
\text { visitas às casas }\end{array}$ & fazer trilhas para facilitar o acesso das pessoas \\
\hline Deixar como está & proibir a captura de animais nativos \\
\hline Construção de casas populares & proibir as empresas de jogarem agrotóxicos e poluentes \\
\hline Construção de ruas ligando os bairros & $\begin{array}{llllll}\text { incentivar as empresas a investir capital para a } \\
\text { preservação do lugar }\end{array}$ \\
\hline Não respondeu & investimento de uma verba da prefeitura para que \\
\hline
\end{tabular}




\begin{tabular}{|l|l|}
\hline & preservação da área seja efetivada \\
\hline & plantar variedades de árvores para a melhoria do ar \\
\hline & $\begin{array}{l}\text { a prefeitura implantar um sistema de tratamento de } \\
\text { esgoto, eliminando o despejo de impurezas e dando } \\
\text { oportunidade para a natureza se recompor }\end{array}$ \\
\hline & $\begin{array}{l}\text { a população se conscientizar em preservar os rios, não } \\
\text { jogando latas, lixos orgânicos, etc. }\end{array}$ \\
\hline $\begin{array}{l}\text { a prefeitura promover a preservação do ambiente através } \\
\text { de divulgação em escolas, indústrias, etc, coleta seletiva, } \\
\text { outdoors em pontos de grande movimentação, mídia } \\
\text { (rádio, TV...); controle de entulhos, com distribuição de } \\
\text { caçambas }\end{array}$ \\
\hline $\begin{array}{l}\text { criação de uma ONG, formada por especialistas e equipes } \\
\text { voluntárias, que possam colher dados de lugares mais } \\
\text { prejudicados }\end{array}$ \\
\hline $\begin{array}{l}\text { precisa haver uma área de preservação com boas } \\
\text { condições de saneamento básico }\end{array}$ \\
\hline
\end{tabular}

Quadro 28: Sugestões das(os) estudantes da EE Maria Ramos para o manejo sutentável da área verde da microbacia do Córrego da Água Quente.

Ao compararmos as sugestões preliminares com as novas sugestões, pudemos perceber que após o segundo encontro educativo em sala de aula, as duas turmas apresentaram sugestões mais detalhadas, mais concretas e mais numerosas para compor uma proposta de manejo sustentável para a área verde. Surgiram nessa segunda coletânea, novas e interessantes idéias como a criação de uma ONG e a formação de mutirões que integrem a própria comunidade para assuntos e ações sobre as áreas naturais do bairro. Esse desejo de se reunir e agir pode ser um primeiro passo para a mobilização da comunidade em favor da conservação da área verde. Por várias vezes as(os) participantes manifestaram a importância da conscientização da população através da intensificação da EA para todas(os), nas escolas e na comunidade, com o objetivo de reduzir a degradação do local. Também foi enfatizada a participação do governo municipal, das empresas e da mídia nas ações de recuperação e conservação da área. Em relação à infra-estrutura para a utilização da área como espaço esportivo e ecoturístico, surgiram várias idéias como a implementação de esportes radicais, trilhas ecológicas, pista de ciclismo e alguns equipamentos de apoio (quadras, lanchonete, etc).

De modo geral, todas(os) os participantes demonstraram bastante interesse em contribuir para a elaboração da proposta de manejo sustentável e pediram que suas sugestões fossem consideradas quando da confecção de tal documento, para que o poder público pudesse conhecer os anseios da população da sub-bacia, uma vez que serão os maiores beneficiados com a recuperação da área verde. 
Registramos aqui o depoimento de uma estudante da EE Orlando Perez que retrata o significado da área verde, e que denota a topofilia existente em relação a esse ecossistema:

“O vale

Os meus mais sinceros sentimentos existe apenas um lugar, porque o vale é um lugar de paz, comunhão, paz de espírito, porque a nossa vida, e de tantas e quantas vidas é feita de uma árvore, eu adoro o vale, eu moro aqui há 10 anos e ele é muito importante para mim.

Gosto muito dele, ele deveria ficar perto da minha casa, iria plantar uma árvore ali todo dia, $e$ iria ensinar a minha filha a crescer vendo como é bela a natureza. Pois a vida é linda e a solidão é trágica. A solidão é linda assim sem ninguém perturbando os animais, não matando os pássaros, etc. A tristeza já é trágica porque numa madrugada alguém com malícia pode jogar fogo numa área que praticamente é o seu coração, porque a Amazônia é o coração do Brasil e o vale é o meu coração. Amo ele. Sofre qualquer pessoa porque ele traz inspiração, bem estar. Adoro quando alguém vai lá e tira lixo dele, ficará melhor ainda se plantarmos mais árvores, menos esgotos, e transformar nosso Córrego da Água Quente em um verdadeiro Parque Ecológico, com animais e pessoas todas juntas no mesmo habitat natural".

\subsubsection{SÍNTESE DA PERCEPÇÃO AMBIENTAL E SABERES DAS(OS) ESTUDANTES EM RELAÇÃO À ÁREA VERDE DA MICROBACIA}

As três turmas escolhidas para participar desta pesquisa eram formadas por estudantes entre 16 e 34 anos, todas(os) residentes na microbacia, compondo um universo de 66 participantes.

A comparação dos resultados obtidos junto às(aos) estudantes com os do estudo de percepção da comunidade mostrou várias semelhanças. Igualmente à comunidade, a análise dos mapas mentais indicou que os elementos mais percebidos pelas(os) estudantes também são a vegetação e os corpos d'água, e igualmente o córrego da Água Quente foi citado poucas vezes, mesmo estando indicado no mapa mental e tendo sido abordado em sala de aula nas EE Aracy Pereira Lopes e EE Orlando Perez. Todavia, ao perguntar sobre os seus conhecimentos em relação aos componentes da área verde após esclarecer a que local nos referíamos, as turmas da EE Aracy Pereira Lopes e da EE Orlando Perez citaram predominantemente a fauna, e somente a da EE Maria Ramos continuou a destacar a vegetação.

Em relação ao conhecimento da fauna, foi possível observar que aquelas(es) que já haviam visitado a área em uma aula de campo (estudantes da EE Aracy Pereira Lopes), apresentaram um número bem mais elevado de espécies, confirmando o potencial educativo das práticas pedagógicas desenvolvidas em ecossistemas naturais. 
Assim como na comunidade, também entre os estudantes os aspectos do relevo são utilizados para dar nome à área verde, e estes nomes variam em função da topografia dos bairros onde residem (alguns na região mais alta da microbacia e outros em altitude semelhante à da área verde), ou seja, os nomes variam entre vale (que foi o mais citado), buracão, barroca e morro, de acordo com o ponto a partir de onde a área é avistada.

A percepção das(os) estudantes sobre os impactos ambientais também coincidiu com a da comunidade, em que receberam maior destaque a poluição hídrica, tanto das nascentes quanto do córrego, e a presença de variados tipos de resíduos sólidos.

Ao perguntar sobre os elementos da paisagem observados no trajeto entre as residências e as escolas, constatamos que os componentes antrópicos são os mais percebidos pelas três turmas, e que a área verde não possui grande destaque na observação cotidiana dessas pessoas. Entretanto, a grande maioria afirmou existir área verde em seu bairro e praticamente a metade já a visitou pelo menos uma vez, o que interpretamos como positivo em dois aspectos: o fato de considerarem a área verde como pertencente ao bairro, que pode denotar um sentimento de pertencimento e facilitar a motivação para o zelo pelo local, e o contato mais íntimo com a mesma, que pode suscitar a topofilia a partir da convivência e da apreciação estética dos detalhes.

No que se refere à atual qualidade ambiental da área verde, 42\% responsabilizam o poder público municipal, desconsiderando a parcela de responsabilidade da população. Todavia, 57\% manifestam a importância da participação da comunidade local nas decisões relacionadas ao manejo da área, por entender que como moradores circunvizinhos são os principais interessados na melhoria da qualidade ambiental desse ecossistema, mas somente $25 \%$ destacam a importância do diálogo e da parceria entre a população e o governo municipal.

A topofilia, analisada a partir do conjunto de respostas e com base no significado da área verde, predominaram entre as(os) estudantes. $\mathrm{O}$ elemento que mais contribuiu para a topofilia das(os) estudantes, assim como no caso das pessoas entrevistadas da comunidade, foi a beleza da paisagem com ênfase na vegetação. A topofobia, por sua vez, foi baseada em uma visão pessimista em relação à área verde, com ênfase na poluição dos corpos d'água e do solo e na presença de animais indesejáveis, ambos relacionados à veiculação de doenças, e causadores de sensações de mal-estar (ou “desconsolo psíquico", de acordo com o conceito de Cunha (2000), citada por Marin, 2003). 
Pudemos observar também bastante interesse por parte das(os) estudantes em apresentar sugestões para o manejo da área verde e constatamos que a topofilia justifica as sugestões de manejo, nas quais predominaram as relacionadas à recuperação e conservação. As propostas de manejo foram detalhadas em idéias para a redução e prevenção de impactos, visando a melhoria da qualidade da água e do solo e a conservação da biodiversidade. Também merecem destaque as propostas de uso da área verde como espaço ecoturístico e de lazer, e a necessidade de físcalização e de atividades de educação ambiental junto à população.

Ficou evidente que dentre as três turmas, a que melhor conhecia a área verde e seus componentes antes de nossa intervenção era a da EE Aracy Pereira Lopes, que visitara a área com a professora, seguida pela turma da EE Orlando Perez que já havia estudado sobre bacias hidrográficas e ouvido falar especificamente sobre a Microbacia do Água Quente em sala de aula.

Avaliamos que tanto os encontros educativos nas escolas, como a visita à área verde com a turma da EE Orlando Perez contribuíram para a nossa compreensão sobre a percepção ambiental e o significado da área verde para este público, e suscitaram às(aos) estudantes a reflexão sobre a importância daquele local, sobre suas atitudes com relação a ele e às questões ambientais em geral, e sobre seu direito e dever, como cidadãs e cidadãos, de participar nas decisões que dizem respeito a interesses coletivos.

Essa motivação foi observada tanto durante as atividades em sala de aula, através das perguntas, comentários e elaboração de sugestões, como no empenho para participar de atividades como o arrastão ecológico, a coleta para análise da qualidade de água, a identificação de espécies vegetais e a exposição dos resultados da visita na EE Orlando Perez.

Ao comparar as sugestões preliminares de manejo com aquelas apresentadas após os encontros educativos, notamos nas posteriores um maior grau de detalhamento e a predominância de propostas mais concretas - tanto para a recupeção e conservação dos componentes naturais quanto para a utilização pela comunidade - de modo a viabilizar o manejo sustentável da área verde da microbacia.

A partir desses resultados, concluímos que a área representa uma "grande sala de aula natural" para a EA escolar, com grande potencial para complementar os processos de ensino-aprendizagem de todas as disciplinas do currículo, podendo inclusive servir como tema-gerador para a implementação de projetos temáticos multidisciplinares. A 
seguir apresentamos uma sugestão para a utilização desta (ou de outra) área verde como tema-gerador (figura 53).

\section{A EDUCAÇÃO AMBIENTAL COMO PRÁXIS}

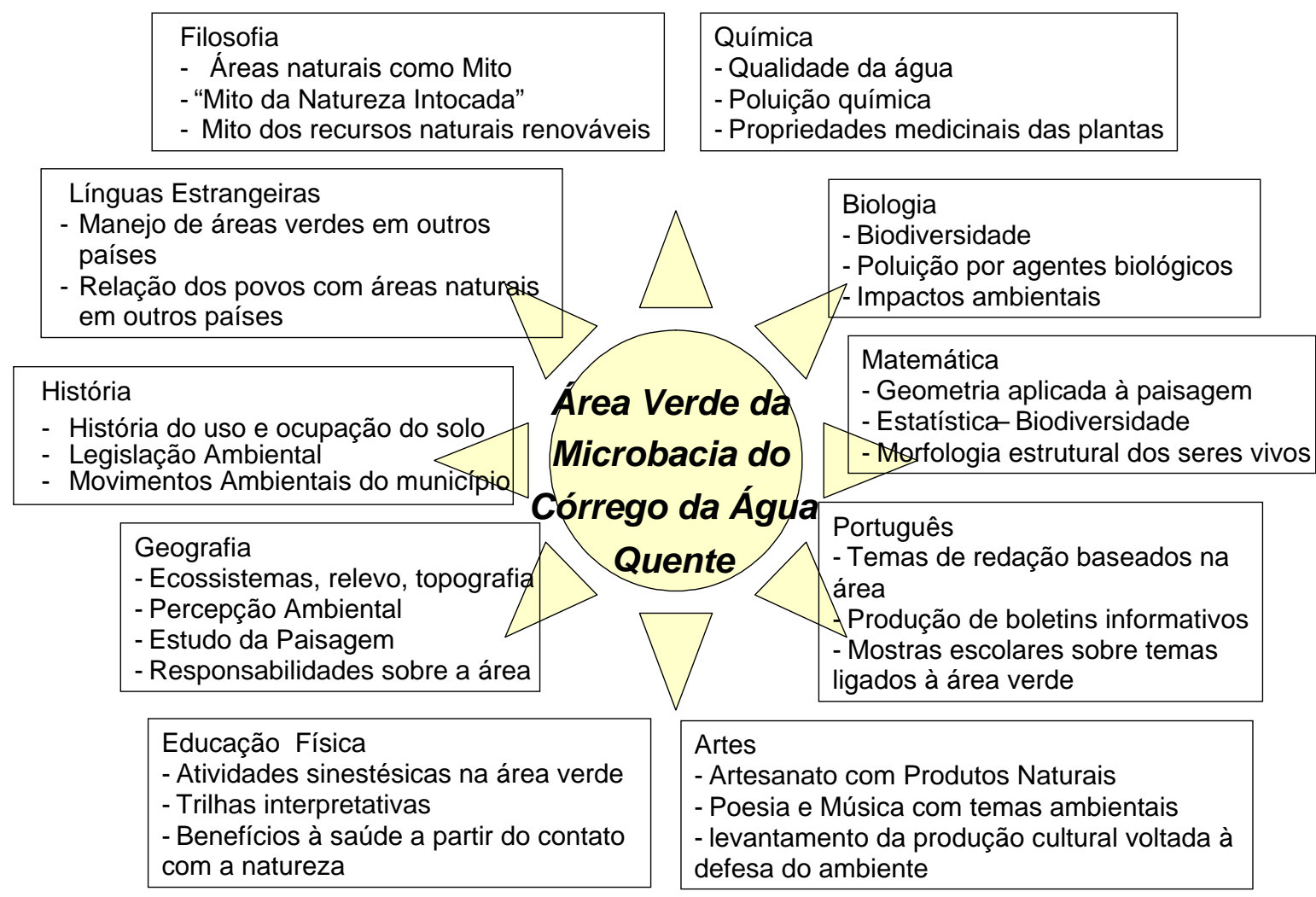

Figura 53: A área verde da Microbacia do Córrego da Água Quente como tema-gerador para projetos escolares multidisciplinares. 


\section{SÍNTESE DAS RELAÇÕES ENTRE A PERCEPÇÃO $\mathrm{E}$ A CARACTERIZAÇÃO AMBIENTAIS E SUA CONTRIBUIÇÃO PARA A EDUCAÇÃO AMBIENTAL}

A análise dos resultados baseou-se na idéia de que a percepção e a caracterização ambientais possuem fortes inter-relações e que ambas são igualmente importantes e complementares como subsídios para intervenções educativas junto à comunidade local, que visem a consolidação de um manejo participativo e sustentável da área verde. Corroborando com essa afirmação, o organograma a seguir (Figura 54) sintetiza as diferentes etapas desenvolvidas e resultados obtidos durante esta pesquisa e as interações entre os elos que a compuseram. Em síntese, o estudo da percepção ambiental da comunidade local em relação à área verde permitiu uma análise das relações de topofilia/topofobia e possilibitou a comparação entre os saberes locais daquela comunidade em relação à área com a caracterização ambiental da mesma. Além disso, observamos que tanto a topofilia (predominante entre as pessoas participantes) quanto os saberes locais, baseiam-se principalmente no sentimento de pertencimento em relação à área verde e/ou na consciência do valor ambiental (ecológico, estético e social) desse local. E que esses aspectos constituem importante ponto de partida para que, através de intervenções educativas, a comunidade se envolva em atividades de recuperação e conservação da área verde e seu entorno. 


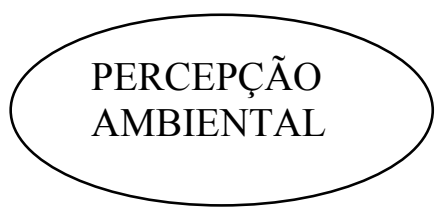

Baseou-se na
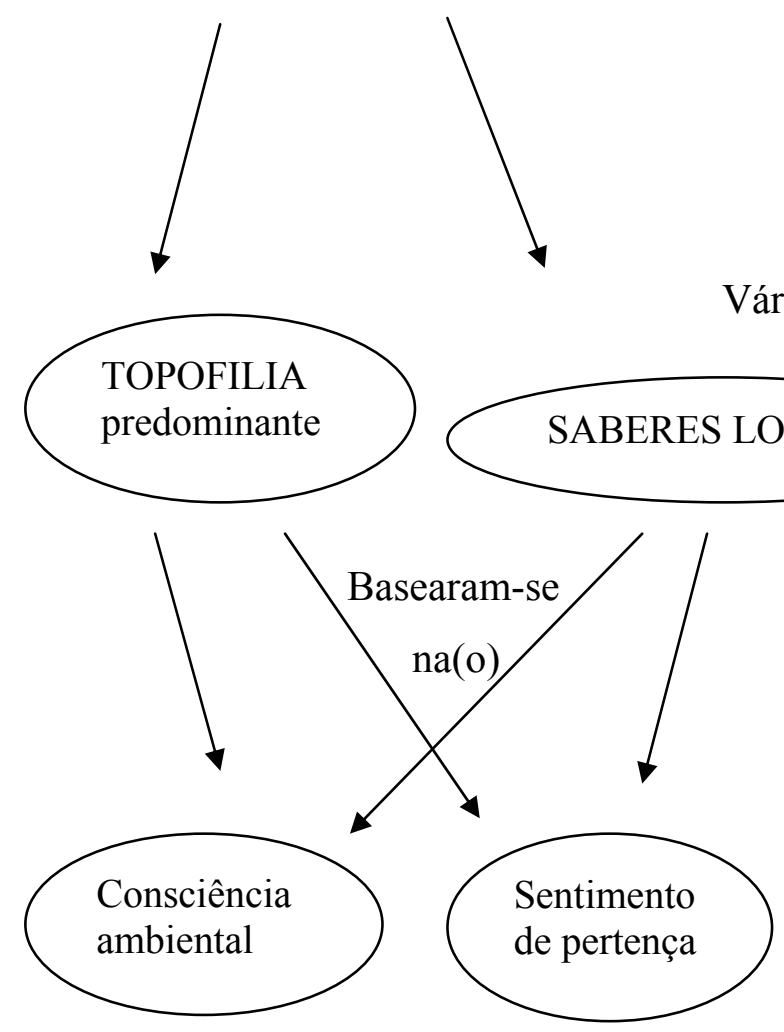

que, a partir de intervenções educativas, podem contribuir

para despertar a noção de
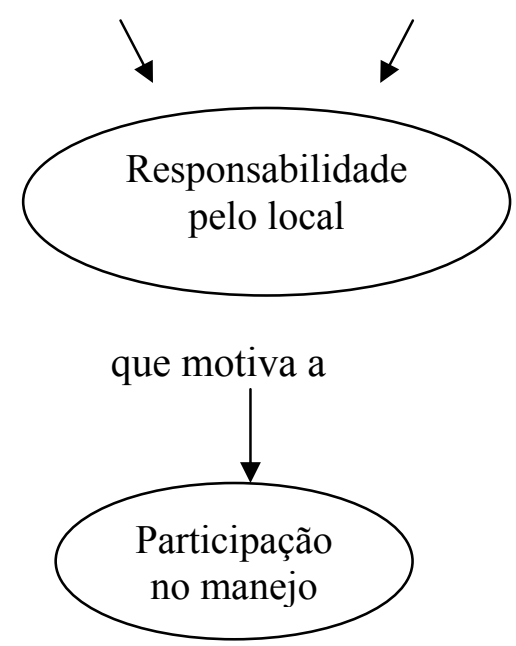

Figura 54: Organograma da seqüência e das inter-relações das análises desenvolvidas. 


\section{A PRÁXis: A MOTIVAÇÃo PARA A PARTICIPACAO POLÍticA A PARTIR DE PROJETOS PARTICIPATIVOS DE EDUCAÇÃO AMBIENTAL}

A partir da análise dos resultados dessa pesquisa à luz de alguns referenciais teóricos que justificam a escolha de uma EA que seja politizante, dialógica, participativa, contextualizada e emancipatória, sintetizamos aqui o que acreditamos ser o papel desse modelo de EA que defendemos, na práxis dos processos educativos.

Projetos de EA escolar e comunitária que utilizem a área verde como tema podem ser uma oportunidade para despertar na comunidade a consciência política, motivando-a à reflexão crítica sobre direitos e deveres (de ter acesso à área, de ter acesso ao conhecimento científico produzido sobre ela, de participar nas decisões e no manejo da área), e levando-a a entender que é capaz, quando organizada e mobilizada em torno de objetivos comuns, de ser sujeito da própria história local e influenciar na história do país.

As intervenções educativas podem contribuir para aproximar a população organizada do poder público para dialogar, sugerir e trocar experiências (uma vez que as(os) moradoras(es) são detentoras(es) do saber local) e fiscalizar, denunciar e reivindicar melhorias para a microbacia que garantam a qualidade de todas as formas de vida.

Se realmente participativos, esses projetos podem auxiliar na compreensão de que a comunidade tem o direito de participar nas decisões e intervenções sobre/na/para a área verde (seguindo a proposição de Lucas, 1980/81), uma vez que sua qualidade de vida é influenciada pela qualidade ambiental desse ecossistema. E para exercerem uma participação efetiva, é fundamental que conheçam a situação ambiental atual e a dinâmica ecológica do local.

Para tanto, projetos de EA podem proporcionar à comunidade informações sobre as funções ambientais (ecológicas e sociais) da área verde (biodiversidade, clima, qualidade do ar, paisagem, recarga do aqüífero, plantas medicinais), e sua qualidade ambiental atual (partindo da contextualização histórica do estado de degradação e suas causas e conseqüências, destacando os principais impactos, indicando os responsáveis e os caminhos para recuperação e conservação).

Sabemos que o livro didático ainda é o material mais freqüentemente utilizado em nossas escolas, e que geralmente se refere a paisagens e ecossistemas distantes da 
realidade local. Para suprir essa deficiência, informações sobre a área verde e a microbacia podem ser geradas coletivamente através de levantamentos participativos sobre as características ambientais da área, e os dados podem ser disponibilizados para as escolas e entidades através de materiais didáticos próprios como jogos, materiais audiovisuais, registros fotográficos, atlas da microbacia, maquetes, atlas da biodiversidade da microbacia, banco de sementes nativas para a formação de um viveiro de mudas a serem usadas para a recomposição vegetal da área, etc, de modo que a comunidade escolar e a população local possam conhecer melhor os componentes naturais da paisagem local (elementos bióticos e abióticos, a dinâmica ecológica do cerrado e da floresta de transição, a dinâmica da bacia hidrográfica, etc) e suas funções ambientais.

Para que os projetos de EA voltados à conservação da área verde tenham caráter permanente, entendemos que devem ser emancipatórios, ou seja, prever o incentivo à mobilização da comunidade para a formação de ONGs (organizações nãogovernamentais) ambientalistas, através da identificação de lideranças comunitárias e do envolvimento das diferentes faixas etárias de moradoras(es), de modo a reunir diferentes saberes, idéias e sonhos para o manejo da área e a incentivar a comunidade a assumir, juntamente com o poder público, a gestão participativa da microbacia.

As intervenções educativas são espaços adequados para a elaboração coletiva de propostas de manejo sustentável para as áreas naturais do município - e em especial para a área verde da MCAQ - a serem encaminhadas para os gestores e incluídas em um plano diretor municipal, que no caso do município de São Carlos, está sendo elaborado.

Por fim, é fundamental que estas propostas considerem os impactos ambientais a curto, médio e longo prazo, incluindo aqueles que podem ser ocasionados pelas próprias atividades de EA a serem desenvolvidas nessas áreas (que por serem intervenções antrópicas, obviamente também provocarão impactos que devem ser minimizados). Para isso, a comunidade-educanda-e-educadora e as(os) educadoras(es) externas(os) devem estar conscientes da frágil capacidade de suporte dessa área verde. 


\section{CONSIDERAÇÕES FINAIS}

O levantamento da avifauna permitiu observar que ainda é relativamente grande a variedade de espécies, mas que a sobrevivência destas está ameaçada pelo conjunto de todos os impactos presentes nesse ecossistema, e que é necessária a minimização desses impactos para a manutenção da avifauna, que tem também um importante papel na recomposição da vegetação como polinizadora (no caso dos beija-flores) e dispersora de sementes.

O levantamento das espécies vegetais revelou o grande potencial da área como banco de princípios ativos medicinais, em contraste com a acentuada perda de vegetação ripária e de cerrado conseqüente da erosão, em extensos trechos ao longo dos corpos d'água.

A partir da caracterização limnológica do Córrego da Água Quente e de suas nascentes, concluímos que a qualidade destes corpos d'água torna-os inadequados para qualquer um dos usos indicados pela legislação vigente (Resolução Conama 20, alterada pela Resolução Conama 357, de 17/03/05, por estar em desacordo com o padrão estabelecido para corpos d'água enquadrados como classe 2). Nesse sentido, ressaltamos a importância da construção da ETE que receberá os efluentes domiciliares atualmente despejados sem nenhum tratamento no córrego da Água Quente, e da construção do Aterro Municipal de Entulhos de Construção, e a urgência de informar a comunidade local sobre os riscos do contato com essa água, o que pode ser feito através de placas no local e divulgação pela mídia.

Ao compararmos a percepção ambiental da comunidade e das(os) estudantes com os dados obtidos na caracterização ambiental da área verde, avaliamos que a percepção em relação aos impactos coincide com a atual situação da área, e que os conhecimentos da comunidade sobre a avifauna convergem com os levantamentos, mostrando que os saberes locais são um precioso banco de dados sobre aquele ecossistema. 
O estudo da percepção foi importante porque revelou as relações da comunidade com a área verde (topofilia ou topofobia) e servirá para nortear as futuras intervenções educativas voltadas à sensibilização e ao envolvimento da população da microbacia. A beleza da paisagem que se destacou na percepção das(os) participantes aponta para a importância da área também por sua contribuição para a valorização paisagística dos bairros adjacentes.

O estudo da topofilia da comunidade em relação à área verde contribuiu para elucidar quais as características mais apreciadas do local, e que por isso merecem destaque em projetos que visem despertar ou aumentar essa topofilia e/ou reduzir a topofobia algumas vezes manifestada.

As sugestões de manejo apresentadas pelas(os) estudantes atestam que a topofilia está intimamente relacionada à motivação para a participação no manejo da área.

Trabalhamos nas dimensões da microbacia hidrográfica, o que facilitou a compreensão das relações entre vários de seus componentes, com destaque para o componente humano.

Nossas expectativas de que, por trabalharmos em uma área de mananciais, o elemento água teria maior destaque na percepção das(os) participantes, foram substituídas pela constatação de que houve uma ruptura das relações da comunidade com esse componente natural. Isso indica a necessidade de pesquisas e intervenções que tracem possibilidades para se restabelecer as relações das pessoas com o córrego, de modo a resgatar a imagem e o reconhecimento da importância deste na microbacia.

Ficou claro que ainda prevalece entre as pessoas da comunidade a falta de participação política, e que há a necessidade de intervenções educativas que esclareçam que a gestão da área verde não cabe somente ao poder público, e só será sustentável se todas(os) dividirem essa responsabilidade.

Finalmente, confirmamos que a EA é capaz e tem o papel de, na mesma medida, despertar ou fortalecer a topofilia, relacionada à mudança de atitudes do indivíduo, mas 
também contribuir para a conscientização de que a crise ambiental local e mundial reflete os paradigmas atuais dominantes, e que somente indivíduos ambientalmente conscientes, mas também unidos e organizados, são capazes de resistir e lutar pela construção de sociedades mais sustentáveis. 


\section{PERSPECTIVAS FUTURAS}

Quanto às novas ações relacionadas à continuidade deste trabalho, pretendemos:

- disponibilizar o material produzido neste e nos demais projetos que vêm sendo desenvolvidos na microbacia através da realização de encontros educativos com a comunidade, visando a motivação desta para atuar como principal reivindicadora das intervenções necessárias à melhoria da qualidade ambiental da microbacia.

- produzir, a partir dos dados aqui compilados, materiais didáticos locais para o estudo da área verde nas escolas situadas na microbacia e eventualmente de outros locais.

- oferecer cursos para as(os) professoras(es) das escolas inseridas na microbacia e demais educadoras(es) comunitárias(os) interessadas(os) sobre a MCAQ, com ênfase na área verde para que sejam multiplicadoras(es) das informações disponibilizadas nesta e em outras pesquisas.

- contribuir, a partir da apresentação deste trabalho aos gestores municipais, para a elaboração de um plano diretor municipal fundamentado na gestão participativa. 


\section{RECOMENDAÇÕES}

Mediante os resultados obtidos nesta pesquisa, recomendamos:

- o desenvolvimento (com urgência) de projetos de Educação Sanitária junto à comunidade da microbacia, principalmente voltados às crianças e jovens, visto que muitas(os) têm contato direto com água e solo contaminados e os mais diversos tipos de resíduos, se expondo a doenças infecto-contagiosas e ao risco de ferimentos.

- o monitoramento da qualidade da água do córrego da Água Quente e de suas nascentes, através de projetos de pesquisa ou pelos órgãos governamentais competentes (CETESB, SAAE, DAEE), e a disponibilização permanente destes resultados atualizados à população.

- novos estudos de levantamento da biodiversidade local, com o objetivo de evidenciar a importância da recuperação desta área verde para a conservação da biodiversidade.

- a elaboração e aplicação de cursos de EA para a formação de professores, voltados à conservação de áreas naturais e ao seu potencial educativo, para que as atividades educativas desenvolvidas na área respeitem a capacidade de suporte da mesma.

- a implementação de projetos para a mobilização das lideranças comunitárias em torno da questão ambiental. 


\section{REFERÊNCIAS BIBLIOGRÁFICAS}

AGUIAR, R. L. (1988) Mapeamento geotécnico da área de expansão urbana de São Carlos - SP: contrituição ao planejamento. 127p. Dissertação (Mestrado em Geotecnia) Escola de Engenharia de São Carlos, Universidade de São Paulo. 1988

AMERICAN PUBLIC HEALTH ASSOCIATION / WWW (1995) Standard methods for the examination of water and wastewater. 11ed. APHA. Washington. $1268 \mathrm{p}$.

AMERICAN PUBLIC HEALTH ASSOCIATION/ AWWAS (1998) Standard Methods for the examination of water and wastewater. 20 ed. American Water Work Association, Water Pollution Control Federation. Washington. pp 9-69.

ART, H. W. (2001) Dicionário de ecologia e ciências ambientais. São Paulo: Editora Unesp/Melhoramentos.

AUGÉ, M. (1994) Não-lugares. Introdução a uma Antropologia da Supermodernidade. São Paulo: Papirus.

BARBOSA, J. L. (1998) Paisagens americanas: imagens e representações do wilderness. Espaço e cultura, n. 5, jan./jun., pp. 43-53.

BAUER, C. E. (1988) Environmental management of water basins. In: TUNDISI, J. G. (ed.) Limnologia e manejo de represas. Vol. 1. São Carlos: ACIESP/FAPESP.

BAUER, M. W.; GASKELL, G. (2003) Pesquisa qualitativa com texto, imagem e som. Um manual prático. $2^{\mathrm{a}}$ ed. São Paulo:Vozes.

BJORNBERG, A. J. S.; TOLENTINO, M. (1959) Contribuição ao estudo da geologia e águas subterrâneas em São Carlos. Boletim da Sociedade Brasileira de Geologia. v.8 n.2. São Paulo.

BOFF, L. (1999) Saber cuidar: ética do humano, compaixão pela terra. Petrópolis: Vozes. 199p.

BONTEMPO, M. (1994) Medicina natural. São Paulo: Nova Cultural. 584p.

BRANCO, S. M. (1986) Hidrobiologia aplicada à Engenharia Sanitária. $3^{\mathrm{a}}$ ed. São Paulo: CETESB. 640p.

BRANDÃO, C. R. (1999) A participação da pesquisa no trabalho popular.. In: BRANDÃO, C. R. (org.) Repensando a Pesquisa Participante. São Paulo: Brasiliense. p.7-14.

BRANDÃO, C. R. (1999) Participar-pesquisar. In: BRANDÃO, C. R. (org.)

Repensando a Pesquisa Participante. São Paulo. Brasiliense. 252p.

BRASIL (1965), Código Florestal Brasileiro (Lei 4771 de 1965 alterada pela Lei 7.803/89).

BRASIL (1981) Lei Nº 6.938/81 Política Nacional do Meio Ambiente. São Paulo: Ed. Saraiva. 
BRASIL (1989) Lei Nº 4771/65 alterada pela lei 7.803/89 Código Florestal Brasileiro. Ministério do Meio Ambiente. Brasília.

BRASIL (1995) Legislação federal: controle da poluição ambiental. São Paulo: CETESB,. 213p.

BRASIL (1997) Lei N ${ }^{0}$ 9.433/97 Política Nacional de Recursos Hídricos. Ministério do Meio Ambiente. Brasília.

BRASIL (1998) Lei de Crimes Ambientais (Lei 9.605/98)

BRASIL (1999) Constituição da República Federativa do Brasil (CF/88) - São Paulo: Editora Revista dos Tribunais.

BRASIL (1999) Lei Nº 9.795/99 Política Nacional de Educação Ambiental. Ministério do Meio Ambiente. Brasília.

BRASIL, Resolução CONAMA 20. IBAMA/MMA. Alterada pela resolução 357 de 17 de março de 2005.

BRÜNING, J. (2003) Existem doenças incuráveis?: bioenergia e saúde. Curitiba: Expoente. 288p.

CABRAL, L. O.; BUSS, M. D. (2001). A paisagem como campo de visibilidade e de significação: um estudo de caso. OLAM- Ciênc. \& Tec. v.1 n.2 p.166-186. Rio Claro. CD-ROM

CALIJURI, M. C.; OLIVEIRA, H. T. (2000), Manejo da qualidade da água: uma abordagem metodológica. In: CASTELLANO, E. G.; CHAUDHRY, F. H. Desenvolvimento Sustentado: Problemas e Estratégias. São Carlos. p.39-58.

CARVALHO, I. C. (2004) Educação ambiental crítica: nomes e endereçamentos da educação. In: LAYRARQUES, P. P. (coord.) Identidades da educação ambiental brasileira. Brasília: Ministério do Meio Ambiente, Diretoria de Educação Ambiental. $156 \mathrm{p}$.

CARVAlHO, J. C. M. (1995) Atlas da Fauna Brasileira. $3^{\text {a }}$ edição. São Paulo: Companhia Melhoramentos. 140p.

CASAldÁligA, P. (2002) Culturas em diálogo. Agenda Latino-americana mundial 2002. São Paulo: Loyola.

CASTELlO, L. (1999) A Percepção em análises ambientais in Percepção Ambiental: A experiência brasileira - Vicente Del Rio e Lívia de Oliveira (orgs.) São Carlos: Studio Nobel, UFSCar. p. 3-22.

CASTELlO, L. (2001) Educando Educadores. OLAM - Ciênc. \& Tec. v.1 n.2 - p. 153-165. Rio Claro. CD-ROM

CHAPMAN, D. (1992) Water quality assesment. A guide to the use of biota, sediments and water in environmental monitoring. 1 ed. UNESCO/UNEP. Chapman \& Hall. 
CÔRTES, M. R. et al. (2000) Uso e ocupação da terra na área urbana. In ESPÍNDOLA, E. L. G.; SILVA, J. S. V.; MARINELLI, C. E.; ABDON, M. M. (orgs.) (2000) A bacia hidrográfica do Rio Monjolinho : uma abordagem ecossistêmica e a visão interdisciplinar. São Carlos: Ed. Rima. 187p.

CRISCUOLO, C.; VASCONCELOS, C. H.; SILVA, J. S. V. (2000) Uso e ocupação da terra em 1965 e 1998. In: ESPÍNDOLA, E. L. G.; SILVA, J. S. V.; MARINELLI, C. E.; ABDON, M. M. (orgs.) (2000) A bacia hidrográfica do Rio Monjolinho : uma abordagem ecossistêmica e a visão interdisciplinar. São Carlos: Ed. Rima. 187p.

DAAE (Departamento de Águas e Energia Elétrica) (1974) Estudo das Águas Subterrâneas - Região Administrativa n 6 v.2 e 3, São Paulo.

DAEE (Departamento de Águas e Energia Elétrica) (2005) Divisão das 22 unidades de gerenciamento de Recursos Hídricos do estado de São Paulo.

DEL RIO, V. (1999) Cidade da mente, cidade real - Percepção Ambiental e revitalização na área portuária do RJ. In: Percepção Ambiental: A experiência brasileira -DEL RIO, V. e OLIVEIRA, L. (orgs.) São Carlos: Studio Nobel, UFSCar. p. 3-22.

DEL RIO, V.; OLIVEIRA, L., (1999). Percepção ambiental: a experiência brasileira. $2^{\mathrm{a}}$ ed. São Paulo, Studio Nobel, 265p.

DEMO, P. (1988) Participar é conquista. São Paulo. Contexto.

DI GIOVANNI, P.C.; COSTA, G.G.G.; OLIVEIRA, H.T.; PRIMAVESI, O.; ROCHA FILHO, J. (1999) A Bacia Hidrográfica como unidade de estudo no desenvolvimento de um projeto de educação ambiental em uma escola pública de São Carlos, S.P. In: CONGRESSO GIS-BRASIL/99 , 1999, Salvador, Ba. Anais... 19-23/Julho/1999.

DIETZ, L. A. H. e NAGAGATA, E. Y. (1997) Programa de conservação do mico-leãodourado: atividades de educação comunitária para a conservação da Mata Atlântica no Estado do Rio de Janeiro. In TABANEZ, M. F. (Orgs.) Educação Ambiental Caminhos Trilhados no Brasil. Brasília: IPÊ - Instituto de Pesquisas Ecológicas, 133146.

DURIGAN, G. et al. (1999) Inventário florístico do cerrado na Estação Ecológica de Assis, SP. Hoehnea 26(2): 149-172.

DURIGAN, G. et al.. (2004) Plantas do cerrado paulista - imagens de uma paisagem ameaçada. São Paulo. Páginas e Letras Editora e Gráfica. 475p.

DURIGAN, G.; NISHIKAWA, D. L. L; ROCHA, E. et al. (2002) Caracterização de dois estratos da vegetação em uma área de cerrado no município de Brotas, SP, Brasil. Acta bot. bras. 16(3): 251-262.

DURIGAN, G.et al. (2003) The vegetation of priority areas for Cerrado conservation in São Paulo state, Brazil. Edinburgh Journal of Botany. V.60, n.2, p.217-241.

ESPÍNDOLA, E.L.G. (2000) O rio do Monjolinho: estudo de caso. In: ESPÍNDOLA , E. L. G.; SILVA, J. S. V.; MARINELLI, C. E.; ABDON, M. M. (orgs.) (2000) A bacia 
hidrográfica do Rio Monjolinho : uma abordagem ecossistêmica e a visão interdisciplinar. São Carlos: Ed. Rima. 187p.

FERREIRA, A. B. H. (1984) Novo Dicionário da Língua Portuguesa. Rio de Janeiro: Nova Fronteira.

FERREIRA, M. A. V. (2002) Uma análise dos olhares dos moradores e da imprensa escrita sobre a degradação do rio Pardo no município de São José do Rio Pardo, SP. 127p. Dissertação (Mestrado). São Carlos: EESC-USP. 2001

FIEN J. (1993) Environmental Education: a pathway to sustainability. Geelong: Deakin University Press.

FREIRE, P. (1959) Educação e Atualidade Brasileira. Tese de concurso para a cadeira de história e filosofia da educação na Escola de Belas Artes de Pernambuco. Recife.

FREIRE, P. (1987) Pedagogia do Oprimido. $17^{\mathrm{a}}$ edição, Rio de Janeiro: Paz e Terra. $184 \mathrm{p}$.

FREIRE, P. (1989) Educação como prática da liberdade. 19a edição. Rio de Janeiro: Paz e Terra. 150p.

FREIRE, P. (1998) Pedagogia da Autonomia: saberes necessários à prática educativa. $18^{\mathrm{a}}$ edição. Rio de Janeiro: Paz e Terra. 165p.

FREIRE, P. R.; GUIMARÃES, S. (1982) Sobre educação: diálogos. Rio de Janeiro: Paz e Terra.

GAJARDO, M. (1999) Pesquisa participante: propostas e projetos. p. 15-50. In: BRANDÃO, C. R. (org.) Repensando a Pesquisa Participante. São Paulo: Brasiliense. $252 \mathrm{p}$.

GIL (1999) Métodos e técnicas de Pesquisa Social. 2ed. Atlas. São Paulo.

GOLTERMAN, H.L.; CLYMO, R. S.; OHNSTAD, R. (1978) Methods for physical and chemical analysis of freshwater. 2.ed. IBP. Handbook, 8, Blackwell Science Publishers, Oxford.

GONÇALVES, A. R. L. (1986) Geologia ambiental da área de São Carlos, São Paulo. 138p. Tese (Doutorado). Instituto de Geociências, Universidade de São Paulo. 1986.

GONÇALVES, C. W. P. (1989) Os (des)caminhos do meio ambiente $5^{\mathrm{a}}$ edição. Contexto.

GONZAGA, J. L. (2003). Educação Ambiental nas bacias hidrográficas de Ibaté - SP e região, envolvendo o ensino formal: uma visão pedagógica do processo. $142 \mathrm{p}$. Dissertação (Mestrado) - Escola de Engenharia de São Carlos, Universidade de São Paulo.2003.

GOODE, W.J.; HATT, P.K. (1997) Métodos em pesquisas sociais. 6ed. São Paulo. Nacional. 
GUIMARÃES, M. (2004) Educação ambiental crítica. In: LAYRARQUES, P. P. (coord.) Identidades da educação ambiental brasileira. Brasília: Ministério do Meio Ambiente, Diretoria de Educação Ambiental. 156p.

GUIMARÃES, S. T. L. (2001) Filigranas de uma paisagem: um estudo sobre a percepção de lugares do medo. OLAM - Ciênc. \& Tec. v.1 n.2 p. 332-372. Rio Claro. CD-ROM.

HEIDEGGER, M. (1989) Ser e tempo. Parte I. Petrópolis: Vozes.

HÖFling, E.; CAMARGO, H. F. A. (2002). Aves no Campus. Instituto de Biociências da Universidade de São Paulo. Edusp. 3 ed. São Paulo.

HYNES, H. B. N. (1970) The ecology of running waters. Liverpool: Liverpool University Press, 555p.

INSTITUTO BRASILEIRO DE GEOGRAFIA E ESTATÍSTICA (2000) Censo Demográfico 2000: resultados preliminares. Rio de Janeiro, 156p.

ISHIKAWA-FERREIRA, L.; RIBEIRO-NETO, F. B. (2004) Aves aquáticas do Reservatório de Salto Grande e Varjão de Paulínia. In: ESPÍNDOLA, E. L. G. et al. (orgs.) Reservatório de Salto Grande (Americana, SP): Caracterização, impactos e propostas de manejo. São Carlos. Rima. 484p.

JACOBI, P. R. (1998) Educação Ambiental e Cidadania, In: SÃO PAULO (Estado). Educação, Meio Ambiente e Cidadania - Reflexões e Experiências. Secretaria de Estado do Meio Ambiente. Coordenadoria de Educação Ambiental. Annablume. São Paulo.

JACOBI, P. R. (2000a) Cidade e meio ambiente: percepções e práticas em São Paulo. São Paulo: Annablume. 192 p.

JACOBI, P. R. (2000b) Do centro à periferia - meio ambiente e cotidiano na cidade de São Paulo. Ambiente \& Sociedade, ano III nº6/7. p.145-162.

KOROLEFF, S. (1976) Determination of nutrients. In: GRAFFHOSS, K. Methods of seawater analysis. Verlag. Chemie. Weinhein.

KRONKA, F. J. N. et al. (1998) Áreas de domínio do cerrado no Estado de São Paulo: São Paulo: Secretaria de Estado do Meio Ambiente. Instituto Florestal.

KUHNEN, A. (2001). Sociedade e meio ambiente: criação de sentido na interação entre a pessoa e seus espaços de vida. OLAM v.1 n.2 - Ciênc. \& Tec. Rio Claro. CDROM

KUNIEDA, E. (2003) Percepção ambiental e aplicação da estratégia da espéciebandeira para a conservação de um fragmento de floresta estacional semidecídua (Fazenda Canchim - CPPSE - Embrapa, São Carlos, SP). 94p. Dissertação (Mestrado). São Carlos: PPGSEA - CRHEA - Universidade de São Paulo. 2003

LEFF, E. (2001) Epistemologia Ambiental. Cortez. São Paulo. 240p. 
LEGENDRE, L.; LEGENDRE, L. (1983) Numerical Ecology, Amsterdam, Elsevier. $419 \mathrm{p}$.

LEITÃO-FILHO, H. F. (1992) A flora arbórea dos cerrados no Estado de São Paulo Hoehnea 19(1/2): 151:163.

LIMA, R. T. (2003) Percepção ambiental e participação pública na gestão dos recursos hídricos: perfil dos moradores da cidade de São Carlos, SP (Bacia Hidrográfica do Rio do Monjolinho) 94p. Dissertação (Mestrado). São Carlos: PPGSEA - CRHEA - Universidade de São Paulo. 2003.

LORANDI, R. (1985) Caracterização dos solos das áreas urbanas e suburbanas de São Carlos-SP e suas aplicações. 181 p. Dissertação (Mestrado). Escola Superior de Agricultura Luiz de Queiroz, Universidade de São Paulo. 1985.

LORENZI, H. (1998a) Árvores brasileiras - manual de identificação e cultivo de plantas arbóreas nativas do Brasil.. Vol. 1. $2^{\mathrm{a}}$ ed. Nova Odessa. Editora Plantarum $352 \mathrm{p}$.

LORENZI, H. (1998b) Árvores brasileiras: manual de identificação e cultivo de plantas arbóreas nativas do Brasil. Vol. 2. $1^{\text {a }}$ edição. Nova Odessa. Editora Plantarum. $352 \mathrm{p}$.

LORENZI, H. (2003) Árvores Exóticas no Brasil. Plantarum. 368p.

LORENZI, H.; MATOS, F. J. A. (2002) Plantas medicinais no Brasil: nativas e exóticas cultivadas. Nova Odessa: Instituto Plantarum. 511p.

LOWENTHAL, D. (1982) Geografia, experiência e imaginação: em direção a uma epistemologia geográfica. In: CHISTOFOLETI, A. (org.). Perspectivas da Geografia. São Paulo: DIFEL.

LUCAS, A.M. (1980/81) The role of science education in education for the environment. The Journal of Environmental Education, vol.2 (2): pp. 32-37.

LUDKE, M. \& ANDRÉ, M. E. D. A. (1986) A pesquisa em Educação: abordagens qualitativas. EPU. São Paulo. 99p.

LYNCH, K. (1998) A imagem da cidade. São Paulo. Martins Fontes.

MACEDO, S. S. (1999) O Quadro do Paisagismo no Brasil. São Paulo: Faculdade de Arquitetura e Urbanismo FAU/USP, Universidade São Paulo.

MACHADO, L. M. C. O. (1988) Estudo da paisagem: uma abordagem perceptiva. Revista de Geografia e Ensino, Belo Horizonte: Editora da UFMG, p. 37-45.

MACKERETH, F. J. H.; TALLING, J. F. (1978) Water analysis: some revised methods for limnologists. Kendal Freshwater Biology Association., Sci. Publ. n. 36.

MAIER, M. H. (1983) Geoecologia, hidrografia, hidroquímica, clima e processos antrópicos da bacia do Rio Jacaré Pepira (SP). 305p. Tese (Doutorado). Departamento de Ciências Biológicas. UFSCar. 1983. 
MAIER, M. H.(1987) Estudo da variação sazonal das condições físicas e químicas ao longo de um trecho do rio Mogi-Guaçu, Cachoeira de Emas, Estado de São Paulo. 102p. Dissertação (Mestrado). São Paulo: Instituto de Biociências - USP.

MAPA Pedológico Semi-Detalhado. In: ESPÍNDOLA, E. L. G.et al. (eds.) (2000) A bacia hidrográfica do Rio Monjolinho : uma abordagem ecossistêmica e a visão interdisciplinar. Ed. Rima. São Carlos. Escala 1:50.000

MAPA - Tributários da bacia hidrográfica do rio do monjolinho (2002) São Carlos: PMSC. Secretaria Municipal de Desenvolvimento Sustentável, Ciência e Tecnologia.

MARGALEF, R. (1983) Limnologia. Barcelona: Omega. 110p.

MARICATO, E. (1996) Metrópole na periferia do capitalismo: ilegalidade, desigualdade e violência. Hucitec, São Paulo.

MARIN, A. A. (2003) Percepção ambiental e imaginário dos moradores do município de Jardim/MS. 306 p.Tese (Doutorado) São Carlos: Universidade Federal de São Carlos. 2003.

MATHEUS, C. E.; SÉ, J. A. S. (2002) Educação ambiental e recursos hídricos: a experiência do Centro de Recursos Hídricos e Ecologia Aplicada da Escola de Engenharia de São Carlos - Universidade de São Paulo. In: Educação ambiental e cidadania: cenários brasileiros. Santa Cruz do Sul: EDUNISC.

MATHEUS, C. E.; TUNDISI, J. G. (1988) Estudo físico-químico e ecológico dos rios da bacia hidrográfica do Ribeirão do Lobo e represa do Lobo (Broa). In: TUNDISI, J. G. Limnologia e manejo de represas, série Monografias em Limnologia. v.1 p. 419-472.

MATTOS, A. (1982) Métodos de previsão de estiagens em rios perenes usando poucos dados de vazão e longas séries de precipitação. 182p. São Carlos, Tese de doutorado. Escola de Engenharia de São Carlos Universidade de São Paulo USP. 1982.

MATTOS, A. (1984) Bacias representativas do Rio Jacaré-Guaçú. Publicação Convênio EESC - DNAEE. São Carlos 1984.

MICROBACIA do Córrego da Água Quente - Ocupação urbana, planimetria e altimetria. (2001) São Carlos. 1 mapa. CENTRO DE DIVULGAÇÃO CIENTÍFICA E CULTURAL - CDCC, USP. São Carlos. Escala 1:10.000.

MICROBACIAS urbanas de São Carlos São Carlos. 1 mapa. CENTRO DE DIVULGAÇÃO CIENTÍFICA E CULTURAL - CDCC, USP. São Carlos. Escala $1: 10.000$

MINISTÉRIO DO MEIO AMBIENTE/IDEC (2002) Consumo sustentável: manual de educação. Brasília: Consumers International/MMA/IDEC. 144p.

MONTANO, M. (2002) Os recursos hídricos e o zoneamento ambiental: o caso do Município de São Carlos (SP), Dissertação (Mestrado em Hidráulica e Saneamento) EESC - USP.2002. 
MOTTA-JUNIOR, J. C. \& VASCONCELLOS, L. A. da S. (1996) Levantamento das aves do campus da Universidade Federal de São Carlos, Estado de São Paulo, Brasil. In: Seminário Regional de Ecologia, 7. Resumos. UFSCar, SP.

MOTTA-JUNIOR, J. C. (1990) Estrutura trófica e composição da avifauna de três habitats terrestres na região central do Estado de São Paulo. Ararajuba 1: 65-71.

MOTTA-JUNIOR, J. C.; LOMBARDI, J. A. (1990) Aves como agentes dispersores da copaíba (Copaifera langsdorffii, Caesalpiniaceae) em são Carlos, estado de São Paulo. Ararajuba 1: 65-71.

MURO, M. R. (2000) “Carta de Zoneamento para Seleção de Áreas frente à Instalação de Aterros Sanitários no Município de São Carlos”, EESC - USP, 2000.

ODUM, E. P. (1986) Ecologia. Guanabara Koogan. Rio de Janeiro. 434 p.

OLIVEIRA, H.T. (2002) Potencialidades do uso educativo do conceito de bacia hidrográfica em programas de EA. In: SCHIAVETTI, A. \& CAMARGO, A.F.M. (eds.) Conceito de Bacias Hidrográficas: teoria e aplicações. Ilhéus: Editora EDITUS/UESC. p. 125-139 (ISBN: 85-7455-053-1).

OLIVEIRA, J. B.; PRADO, H. (1984) Levantamento Pedológico Semidetalhado do Estado de São Paulo. Quadrícula de São Carlos. Campinas: Instituto Agronômico de Campinas (IAC). Boletim Técnico n.98. 188p. escala 1:100.000

ORNSTEIN, S. W.(2001) Aplicando questionários na avaliação pós-ocupação do ambiente construído: ponderações sobre os procedimentos adotados nos últimos 20 anos. OLAM - Ciênc. \& Tec. v.1 n.2 p. 314 - 331. Rio Claro. CD-ROM

PEDROSO, F.; BONETTO, C.A; ZALOCAR, Y. (1988) A comparative study on phosphorus and nitrogen transport in the Paraná, Paraguai and Bermijo rivers. In: Limnologia e Manejo de Represas. Séries: Monografias em Limnologia. São Paulo. Aciesp. V.1, p91-117.

PEGORARO, J. L. (1998) Educação ambiental: a temática da flora, da fauna e dos ambientes naturais (expressões da biodiversidade) a partir da educação formal. 203p. Dissertação (Mestrado) Piracicaba: Escola Superior de Agricultura Luiz de Queiroz, Universidade de São Paulo. 1998.

PEGORARO, J. L.; MACHADO, C. G. (1992) Pequeno guia ilustrado sobre o Varjão de Paulínia. Campinas. 48p.

PEGORARO, J.L. (2004) Reservatório de Salto Grande: Algumas faces do uso Educativo. In: ESPÍNDOLA, E.L.G.; LEITE, M.A.; DORNFELD, C.B. (orgs.) Reservatório de Salto Grande (Americana, SP): Caracterização, impactos e Propostas de Manejo. Ed. Rima. São Carlos. pp. 379-396.

PEPINO, C. H.; SILVA, E. A.; PERES, R. B. (2002) Análise Ambiental da Bacia do Córrego da Água Quente, São Carlos, SP. São Carlos: Teia Casa de Criação. 37p. 
PIRES, J. S. R. (1995) Análise ambiental voltada ao planejamento e gerenciamento do ambiente rural: abordagem metodológica aplicada ao município de Luiz Antônio, SP. Tese (Doutorado). Universidade Federal de São Carlos. 1995

PREFEITURA MUNICIPAL DE SÃO CARLOS (1989) LEI No 033/89 - Proteção da Flora dentro da zona urbana. São Carlos.

PREFEITURA MUNICIPAL DE SÃO CARLOS (1996) Lei Orgânica do Município de São Carlos.

PREFEITURA MUNICIPAL DE SÃO CARLOS (2000). Mapa da cidade de São Carlos. Marília: Cidade - Propaganda e Comunicação de Marília.

PREFEITURA MUNICIPAL DE SÃO CARLOS (2001) LEI N ${ }^{0}$ 10.257/01 - Plano de Desenvolvimento Integrado do Município de São Carlos - Legislação Básica: Estatuto da Cidade. São Carlos.

PRIMAVESI, O. et al. (2000) A qualidade da água na microbacia hidrográfica do Ribeirão Canchim, São Calos, SP, ocupada por atividade agropecuária. CNPDIA/EMBRAPA-SE.Acta Limnologica Brasiliensia.v.12, pp.95-111.

PROSHANSKI, H. M.; FABIAN, A.; KAMINOFF, R. (1982) "Place identity, psysical wordl, socialization of the self." Journal of Environmental Psychology, n.3, pp. 53-83.

RAFFAINI, G. B.; CORIGLIANO, M. C. (1998) La cuenca como recurso didáctico en Educación Ambiental. Revista de Educación en Biología. pp. 32-36.

RATTER, J. A. (2003) The vegetation of priority areas for cerrado conservation in São Paulo State, Brazil. Edinburgh Journal of Botany. 60 (2): 217-241 (2003).

RAVAGNANI, A.S. (1999) Desenvolvimento de programas de Educação Ambiental utilizando a bacia hidrográfica como método de abordagem e ensino. Dissertação (Mestrado em Conservação e Manejo de Recursos) Rio Claro: PPG /CEA/UNESP.1999.

REGALADO, L. B.; SILVA, C. (1997) Utilização de aves como indicadoras de degradação ambiental. Revista Brasileira de Ecologia. 1: 81-83.

REGALADO, L. B.et al. (2000), Fauna de Vertebrados. In: ESPÍNDOLA , E. L. G.; SILVA, J. S. V.; MARINELLI, C. E.; ABDON, M. M. (orgs.) (2000) A bacia hidrográfica do Rio Monjolinho : uma abordagem ecossistêmica e a visão interdisciplinar. São Carlos: Ed. Rima. 187p.

REID, J. W.; WOOD, R. D. (1976) Ecology of inland waters and estuarie Environmental variables of natural waters. Nova Iorque: Van Nostrand $2 \mathrm{a}$ ed.

REIGOTA, M. (1994) O que é Educação Ambiental. São Paulo:Brasiliense. 60 p.

RELPH, E. C. (1979) As bases fenomenológicas da Geografia. Geografia. n. 7. V. 4, pp $1-25$. 
RIBEIRO, J. F.; FONSECA, C. E. L.; SOUZA-SILVA, J. C. (2001) ed. Cerrado: caracterização e recuperação de Matas de Galeria. Planaltina: EMBRAPA-Cerrados. $899 \mathrm{p}$.

RIOS, L. (1993) Estudo limnológico e fatores ecológicos em ribeirões e córregos da Bacia Hidrográfica do Ribeirão do Feijão (Estado de São Paulo). 146p. Dissertação (Mestrado) Escola de Engenharia de São Carlos. Universidade de São Paulo. 1993.

RIOS, L. E CALIJURI, M.C. (1995) a Bacia Hidrográfica do Ribeirão do Feijão. Uma proposta de ordenação das Sub-bacias através de variáveis limnológicas. Acta Limnologica Brasiliensia, v.7, p.151-161.

ROBOTTOM, I. \& HART, P. (1993) Research in Environmental Education: engaging the debate. Geelong: Deakin University Press.

ROCHA, O.; PIRES, J. S. R.; SANTOS, J. E. (2000) A bacia hidrográfica como unidade de estudo e planejamento. In: ESPÍNDOLA , E. L. G.; SILVA, J. S. V.; MARINELLI, C. E.; ABDON, M. M. (eds.) A bacia hidrográfica do Rio Monjolinho: uma abordagem ecossistêmica e a visão interdisciplinar. Rima. São Carlos.

RODRIGUES, R. R.; LEITÃO-FILHO, H. F. (2000). Matas Ciliares: Conservação e Recuperação. São Paulo. Editora da Universidade de São Paulo: FAPESP. 320 p.

SALAMI, L.N.B.P. (1996) Estudo das influências climáticas e antropogênicas nas características físico-químicas do rio do Monjolinho, São Carlos, São Paulo. 135p. Dissertação (mestrado). CRHEA/USP. São Carlos. 1996.

SALCEDO, R. F. B. (2001) Percepção e revitalização do centro histórico de Ouro Preto -OLAM - Ciências \& Teconlogia v.1 n n 2. pp 263 - 276. Rio Claro. CD-ROM

SANTOS, B. S. (2000) A crítica da razão indolente: contra o desperdício da experiência. São Paulo: Cortez.

SANTOS, J.E.; JESUS, T.P., HENKE-OLIVEIRA, C., BALLESTER, M.V.R. (1996). Caracterização perceptiva da estação ecológica de Jataí (Luiz Antônio, SP) por diferentes grupos sócio-culturais de interação. In: SEMINÁRIO REGIONAL DE ECOLOGIA, 7, São Carlos, SP, 1996. Anais. São Carlos: UFSCar, p.309-353.

SANTOS, M. (1986) Pensando o espaço do homem. São Paulo: Hucitec.

SANTOS, M. F. (1996) Subsídios para o planejamento conservacionista da Bacia Hidrográfica do Ribeirão do Feijão (São Carlos, Itirapina e Analândia, SP). 222p. São Carlos. Dissertação (Mestrado), EESC/USP. 1993.

SANTOS, M. J. (1993) Estudos limnológicos dos Córregos da Água Fria e da Água Quente. 291p. Dissertação (Mestrado). Escola de Engenharia de São Carlos. Universidade de São Paulo. São Carlos. 1993.

SÃO PAULO (1977) Decreto Estadual 10.755/1977 - Enquadramento dos corpos d'água do Estado de São Paulo. 
SÃO PAULO (1987) Lei Estadual no 7.663/91 Criação do Sistema Integrado de Gerenciamento de Recursos Hídricos do Estado de São Paulo.

SÃO PAULO (ESTADO) (1995) Legislação estadual: controle de poluição ambiental. Estado de São Paulo. São Paulo: CETESB,. 300 p.

SÃO PAULO- SECRETARIA DE ESTADO DO MEIO AMBIENTE (1997) Cerrado: bases para a conservação e uso sustentável das áreas de cerrado do Estado de São Paulo. 113p. (Série PROBIO/SP).

SÉ, J. A. S. (1999) Educação Ambiental nas bacias hidrográficas do Rio do Monjolinho e do Rio Chibarro: Ciência, Educação e Ação nos Quotidianos de São Carlos e Ibaté (SP). 254p. Tese (Doutorado). Escola de Engenharia de São Carlos, Universidade de São Paulo. São Carlos. 1999.

SÉ, J. A. S.(1992) O Rio do Monjolinho e sua bacia hidrográfica como integradores de sistemas ecológicos: um conjunto de informações para o início de um processo de pesquisas ecológicas, de educação, planejamento e gerenciamento ambientais a longo prazo. 381p.Dissertação (Mestrado). São Carlos: EESC-USP. 1992

SEARA FILHO, G. (1992) Educação Ambiental: Questões Metodológicas. Ambiente. v. 6 n.1. São Paulo. pp 45-48.

SECRETARIA DE DESENVOLVIMENTO SUSTENTÁVEL, CIÊNCIA E TECNOLOGIA (2002) Microbacia do Córrego da Água Quente (São Carlos, SP) Hipsometria. SMCT, Prefeitura Municipal de São Carlos.

SELLTIZ, C. et al. (1967) Métodos de pesquisa nas relações sociais. São Paulo: Herder.

SERPA, A. (2001) Percepção e fenomenologia: em busca de um método humanístico para estudos e intervenções do/no lugar Rio Claro: CD OLAM v.1 n.2 - Ciênc. \& Tec.

SERRA-FILHO, L. et. al. (1974) Levantamento da cobertura natural e do reflorestamento no Estado de São Paulo. Boletim Técnico do Instituto Florestal. São Paulo, 11.

SICK, H. (1997) Ornitologia Brasileira. Editora Nova Fronteira, Rio de Janeiro, RJ.

SILVA, W. R. (1998) Bases para o diagnóstico e o monitoramento da biodiversidade de aves no Estado de São Paulo. In: Biodiversidade do Estado de São Paulo, Brasil: síntese do conhecimento ao final do século XX, 6: Vertebrados. São Paulo: FAPESP, 41-50.

SILVEIRA, R. A. M.; COLESANTI, M. T. M. (2001) A paisagem urbana sob o enfoque da percepção: um estudo dos Córregos Pito Aceso e Óleo - Uberlândia/MG. OLAM - Ciências \& Teconlogia v.1 n ${ }^{\circ}$ 2. p.263 - 276. Rio Claro. CD-ROM.

STRASKRABA, M.; TUNDISI, J. G. (2000) Abordagens e Métodos para o Gerenciamento das Bacias Hidrográficas. In: Diretrizes para o gerenciamento de lagos. - Gerenciamento da qualidade da água de represas.v.9. Instituto Internacional de Ecologia. São Carlos. pp 141-150. 
TEIA - CASA DE CRIAÇÃO. (2002) Análise ambiental da Bacia do Córrego da Água Quente. São Carlos-SP. Relatório apresentado à Prefeitura Municipal de São Carlos.

TEIXEIRA, D. (1993) Caracterização limnológica dos sistemas lóticos e variação temporal e espacial de invertebrados bentônicos na bacia do Ribeirão do Feijão, São Carlos, SP. Dissertação (Mestrado). CRHEA/USP. São Carlos, SP.

TÓRO-TONISSI, R. M.; OLIVEIRA, H. T.; TONISSI, F.B.; SIMÕES, R.B. (2004) Percepção e educação ambientais para conservação da microbacia do Córrego da Água Quente, São Carlos, SP: uma experiência na escola pública. In: Fórum Nacional de Educação Ambiental, 5. 2004. Goiânia, Goiás.

TÓRO-TONISSI, R. M.; SILVA, C. F.; TONISSI, F. B.; PEREIRA, R. H. G. (1999) Educação Ambiental e Saneamento Básico como alternativas para a prevenção à poluição. (Monografia). Escola de Engenharia de São Carlos. Universidade de São Paulo.

TÓRO-TONISSI, R. M.; TONISSI, F. B. (2002) Projeto de Urbanização Integrado Gonzaga e Monte Carlo - Relatório de Impacto Ambiental. Programa Habitar Brasil BID. Relatório de Impacto Ambiental apresentado à Prefeitura Municipal de São Carlos.

TOZONI-REIS, M. F. C. (2004) Educação ambiental: natureza, razão e história. Campinas: Autores Associados (Coleção Educação Contemporânea). 170p.

TUAN, Y. (1980) Topofilia - Um Estudo da Percepção, Atitudes e Valores do Meio Ambiente. DIFEL. São Paulo. 288 p.

TUAN, Y. (1983) Espaço e lugar, a perspectiva da experiência. São Paulo: DIFEL.

TUNDISI, J. G. (2000) Bases ecológicas para o desenvolvimento sustentado. In: CASTELlANO, E. G.; CHAUDHRY, F. H. Desenvolvimento Sustentado: Problemas e Estratégias. São Carlos. pp39-58.

WETZEL, R. G. (1993) Limnologia. Fundação Calouste Gulbenkian. 2 ed. Portugal.

WHITTON, B. A. (1975) Algae. In: River ecology. Londres: Blackwell Scientific Publications, p. 81-105.

WILSON, E. O. (1993) Biophilia and the conservation ethic. In: The Biophilia Hipothesis. Washington: Island Press, p. 31-41.

WITTHAKER, R. H. (1975) Communities and Ecosystems. $2^{\mathrm{a}}$ Ed. Nova Iorque: Macmillan.

ZEPPONE, R. M. O. (1996) Educação Ambiental: Um projeto de ação em uma escola pública de São Carlos. Dissertação (Mestrado). Universidade Federal de São Carlos. 
ANEXO 1

ROTEIRO DE ENTREVISTA

MICROBACIA DO CÓRREGO DA ÁGUA QUENTE

DATA

NOME:

$\underline{\text { Parte I: }}$

1. SEXO 2. IDADE 3. PROCEDÊNCIA (cidade, estado)

4.TEMPO DE RESIDÊNCIA NO LOCAL:

CARACTERIZAÇÃO SÓCIO-ECONÔMICA

5. NÍVEL DE INSTRUÇÃO: analfabeto; ensino fundamental incompleto; ensino fundamental completo; ensino médio incompleto; ensino médio completo; ensino superior

6. POSSUI FILHOS? Se sim, quantos?

7. SITUAÇÃO DE TRABALHO: assalariado, setor público; assalariado setor privado, c/ carteira; assalariado, setor privado, s/ carteira; trabalhador autônomo; aposentado; desempregado

\section{PROFISSÃO}

9.QUAL SUA ATIVIDADE ECONÔMICA PRINCIPAL?

10. QUAL SUA RENDA MÉDIA MENSAL (EM SALÁRIOS MÍNIMOS) ?

11. ALGUÉM MAIS CONTRIBUÍ PARA A RENDA FAMILIAR ? SE SIM, QUEM?

12. TIPO DE DOMICÍLIO:

alvenaria; tábua/lata; misto

próprio; alugado; emprestado

individual (uma família); coletivo

número de moradores: adultos; menores de 18 anos

NÍVEL SÓCIO-CULTURAL

13. QUAIS SÃO AS ATIVIDADES SOCIAIS QUE VOCÊ REALIZA QUANDO NÃO ESTÁ TRABALHANDO?

Exemplos

ir ao clube

jogar ou assistir partida de futebol ou outro esporte no campo ou quadra

ir à igreja

ver TV Se sim, Qual a programação de maior interesse?

ouvir rádio Se sim, Qual a programação de maior interesse?

visitar vizinhos

visitar parentes

freqüentar parques e/ou áreas verdes

pescar. Se sim, onde?

caçar. Se sim, onde?

leitura de jornal e revistas Se sim, qual(is)?

ir a festas e outros encontros sociais

outros. Especificar

14. PARTICIPA DE ALGUM TIPO DE ASSOCIAÇÃO COMUNITÁRIA DE MORADORES DE BAIRRO E/OU MUNICÍPIO? SE SIM, QUAL ? 
15. TEM ALGUMA RELIGIÃO ? QUAL ?

EM SEUS ENCONTROS (TEMPLO, IGREJA) HÁ OU JÁ HOUVE ALGUM COMENTÁRIO SOBRE MEIO AMBIENTE ? QUAL ?

\section{Parte II: QUESTÕES ESPECÍFICAS - entrevista semi-estruturada}

16) Em sua opinião, como deve ser um bom lugar para se viver na cidade ?

17) Existe alguma relação entre um bom lugar para se viver na cidade e a existência de um local como a área verde ${ }^{1}$ próxima ao seu bairro?

18)O que você pensa sobre a existência da área verde próxima ao seu bairro ?
( ) ótimo
( ) bom( ) regular
( ) ruim( ) péssimo Por que?

19) Existe alguma relação entre a saúde das pessoas do seu bairro e a existência da área verde próxima ao seu bairro ? Qual?

20) Você já foi até a área verde?

( ) sim Há quanto tempo faz isso e com que freqüência? ? ( ) não

21) O que você encontrou na área verde?

22) Há alguma planta com propriedades medicinais ? Qual e pra que serve?

23) Já teve algum contato com a água existente na área verde? ( ) sim ( ) não
( ) contato manual
( ) nadou
( ) ingestão

24) Como estava a água ?

25) Você ou alguém de sua família tiveram alguma alteração no organismo após ter contato com a água ?Qual ?

26) Em sua opinião, quem são os responsáveis pela atual situação do seu bairro e dessa área vrde?

27) Em sua opinião, que são os responsáveis por decidir o que está bom e o que deve ser mudado na área verde?

28) Você tem alguma sugestão para mudança? O que você gostaria que fosse feito na área verde?

29) Gostaria de participar de um encontro sobre propostas para recuperação e manutenção da área verde? ( )SIM ( )NÃO

30) Qual sua opinião sobre esta entrevista ?

\footnotetext{
${ }^{1} \mathrm{O}$ termo área verde foi substituído em todas as questões seguintes por buracão, mata, reserva da prefeitura, vale, nativa, árvores nativas, barroca, morro, etc, de acordo com o nome pelo qual cada participante reconhece a área.
} 


\section{ANEXO 2: Trancrição e agrupamento de duas entrevistas como exemplo das transcrições utilizadas para a análise da percepção ambiental e saberes locais sobre a área verde.}

16. Em sua opinião, como deve ser um bom lugar para se viver na cidade?

eu acho que um bom lugar tem que ter de tudo, porque se não tiver nada não é um bom lugar. Se não tem rede de esgoto feita, não tem canalização, não tem tratamento no bairro, então nós não temos nada. Aquela água mesmo (da área verde) é uma coisa que devia tratar, até pra servir o bairro inteiro. Então eu me preocupo mais com aquela água ali, que é uma água que desde criança a gente bebia ela, sem precisar ferver, sem precisar nada. Tem uma mina lá, ela é no barranco, ela solta aquela água e é térmica. É ali mesmo no Gonzaga, mas descendo o Buracão

17.Existe alguma relação entre um bom lugar para se viver na cidade e a existência de um local como a área verde próxima ao seu bairro (buracão, mata, reserva da prefeitura,vale encantado, vale, nativa, árvores nativa, barroca, morro, etc)?

acho que a mata não tem nada a ver, o que manda é os moradores reservar ela. Tem que conservar ela pra ter um ar livre e a gente morar sossegado, porque aquela área não vai prejudicar morador nenhum de sobreviver num lugar. Ela vai trazer saúde e vai trazer coisas melhores para as crianças, o que manda é o tratamento, é a gente tratar dela, que ela está suja, então não tem como a gente apoderar daquela água do ambiente

18. O que você pensa sobre a existência da área verde próxima ao seu bairro? Por que?

Ótimo, pra mim é importante, porque tantos anos que a gente espera melhorar, é importante bastante. Acho ótimo morar aqui, porque é um bairro sossegado, falta bastante infra-estrutura no bairro, porque o lugar é ótimo, eu não tenho nem vontade mudar. Minha vontade é pedir mais ajuda pra Universidade Federal, USP, junto com esse prefeito que fosse melhorar esse bairro. Falta muita coisa pra fazer, nesse bairro Monte Carlo pra arrumar

19. Existe alguma relação entre a saúde das pessoas do seu bairro e a existência da área verde ?

agora tem, porque justamente a água está suja, e enquanto não limpar não vai voltar a saúde das pessoas, está uma sujeira a água, é de rede de esgoto, é de casa, é de tudo quanto é tipo de coisa que cai ali, e você sabe que na face da terra tem muitas contaminações, que contaminam a água. E se a água é contaminada, contamina as crianças, que não podem brincar lá, não podem ter o direito de ir lá ver nem visitar aquela água lá embaixo, porque sabe que vai entrar, vai pegar febre, contaminar a saúde, pode até beber um gole daquela água, aí contagia outras crianças. Nesse momento tem que ver se faz alguma limpeza no rio pra poder ter ao ambiente da água. $O$ bairro é bom, e eu acho que o lugar é bom mesmo, não é porque é buraco, eu acho que o lugar é ótimo, mas tendo tratamento

20. Você já foi até a área verde ? Se sim, há quanto tempo faz isso e com que freqüência ?

Eu estou acostumada, quando eu vou lá eu choro. Porque era limpa e agora está suja. Eu desço sempre, olhando a mata aí

21. O que você encontrou na área verde?

22. Há alguma planta com propriedades medicinais? 
Lá tem a maior sujeira, coisa podre, roupa velha jogada, lata, cachorro morto, cavalo, é gente que acha morto aí também, acharam morto outro dia. Então acho que aí é um lugar que devia ser mais aberto, ter mais comunicação com as autoridade, por enquanto está fechado aí, né? Olha, não tem coisa melhor, depois que limpar isso aí, eu acho que vai se respirar um ar bem limpo aqui, em são Carlos e no bairro, principalmente pra nós, que eu acho que o negócio é conservar e zelar do bairro. Eu fico olhando aquelas árvores, sentindo aquela sujeira nos pés delas, e elas não tem pra respirar um ar livre, ela tem aquela contaminação (chorando), ela tem que tem um tratamento adequado pra elas poderem respirar, que elas estão presas na sujeira, e não tem como se soltar. Eu fico olhando as árvores, sinto aquela sujeira nos pés delas, me dá até um nervoso. Se eu pudesse sozinha com a minha mão, ia tratar, mas não tem. É muito grande. Se precisar da minha pra um mutirão pra limpar o rio, eu sou a primeira a estar dentro, porque é lógico que é importante.

Tem várias minas, a mais forte é da cabeceira do Gonzaga. As outras ficam nos barrancos das pedras. Ela sai limpinha, mas já está contaminada. Tem gente que está tirando água, fervendo em casa pra beber. Ferve e côa, ela sai branquinha. Dá pra por bambu pra fazer uma canaletinha pra puxar a água. Córrego é o principal do meio ali do ambiente que corre e penetra. É o que vai sair lá no Matadouro, emenda lá com o Feijão, não, com o Gregório, vai descendo, fazendo a volta e emenda lá com o Gregório.

Tem ameixa, jabuticaba, pé de bananeira lá pra baixo, tem pé de amora, limão do campo (caipira), pé de abacate (quintais?).

Já vi 2 raposas grandes, 2 cachorros do mato, cobra tem bastante (jararacão, jararaca, cascavel, coral, salamandra, jibóia, pernilongo, mosquito, maritaca, tico-tico-rei, canário-do-reino, canáriopersa, pomba grande, rolinha fogo-apagou, gralha. A mata não traz cheiro. O mal cheiro que tem sobe pela rede de esgoto quando chove e depois seca. As crianças põem fogo.

23. Já teve algum contato com a área existente na área verde?

24. Como estava a água?

25. Você ou alguém de sua família teve alguma alteração no organismo após ter contato com a água ?Qual ?

Tem várias minas, a mais forte é da cabeceira do Gonzaga. As outras ficam nos barrancos das pedras. Ela sai limpinha, mas já está contaminada. Tem gente que está tirando água, fervendo em casa pra beber. Ferve e côa, ela sai branquinha. Dá pra por bambu pra fazer uma canaletinha pra puxar a água. Córrego é o principal do meio ali do ambiente que corre e penetra. É o que vai sair lá no Matadouro, emenda lá com o Feijão, não, com o Gregório, vai descendo, fazendo a volta e emenda lá com o Gregório.

Tomei a água já faz uns 17 anos. Era limpinha, geladinha, não precisava nem por na geladeira, cristalina, podia por pra criança tomar sem precisar ferver, era limpa mesmo. Eu tenho de testemunha a família do João Ratti, porque eles usavam, e também quando eles fizeram o supermercado deles, não tinha água ali e eles iam buscar de carroça.

Água Quente é o córrego que desce ali embaixo, que faz parte da Água Fria. É esse daqui (da mata) que emenda aí. Esse daqui vai pra lá, entra na Água Quente, que desce na Água Fria. E ele faz parte e emenda pra cair no Gregório.

A gente já nadou, que ele forma parte do areieiro lá embaixo. Já nadou, já abriu valeta pra turma da fábrica de toalha, canalizei tudo a água lá. A água do córrego era excelente. Não tinha cheiro, só que era uma água meio azul, meio escura, mas só que quando pegava no copo era branquinha. Nunca senti nada. Eu faço parte da natureza da água. Eu cheguei na água, ponho um pouquinho, o gosto dela eu conheço se ela é doente. Eu faço na própria boca. Se eu pegar um pouquinho, já no sentido do gosto eu sei se a água está boa, se ela é saudável, salobra, então a gente já sabe o gosto que a água tem. Se a água não tiver gosto de barro, excelente água. Se ela puxar gosto de barro, ela está contaminada. Se ela tem gosto já está pegando contaminação. Então ela tem que ser uma água pura, leve, e não ser pesada, porque você bebeu água e sentiu que ela é pesada, pode fazer exame. Ela já está prejudicando o estômago, porque ela é uma água contaminada. 
26. Em sua opinião, quem são os responsáveis pela atual situação do seu bairro e dessa área verde ?

faltou um pouco do prefeito, porque ele não deu a melhoria que precisava, e chegou no fim ele abandonou nós, deixou nós esquecidos. Tem casa que até hoje nunca foi rebocada porque ele não deu o material suficiente. Agora responsável quem ficou foi o povo mesmo que fez o bairro e não teve resposta concreta do prefeito, porque ele saiu e entregou de qualquer jeito para o outro, e daí foi mudado aqui debaixo de polícia. O Mello tocou polícia, nós morávamos no Jardim Gonzaga, lá na favela, ele foi derrubando os barraco pra gente mudar depressa, vamos mudar sem terminar o bairro, vocês têm que entrar dentro da casa porque o Vadinho vai ganhar de mim, vocês têm que entrar lá, se não entrar pode ficar mais caro (isso aí foi rolo dele). E nós entramos aqui como se fosse cachorro. Minha mãe não conseguiu até hoje rebocar a casa dela. Tem gente até hoje que até chora, porque o homem não conseguiu nem rebocar o banheiro sequer. Ele não terminou e não deu o material suficiente pra nós. Ele fez o projeto de uma casa que está lá em frente a escada, não foi entregue do jeito que ele fez. O Rubinho que asfaltou de graça pra nós. A escritura ele ficou de dar e até hoje não deu pra nós. O responsável é o Vadinho Bicudo, ele não tem como pular fora. A mata, ele foi deixando acabar com tudo, já que ajeitou a rede de esgoto aí não teve conservação mais nenhuma, ficou abandonado. Ele não ligou, ele jogou o esgoto. Antes dele o esgoto tinha que ser na rua, que caía fora do rio, jogava já no esgoto da rua. Ele, pra aproveitar que fizeram mais um bairro grande, ele aproveitou e imbicou, ali na avenida Maranhão. Era pra ele jogar cima, pra cair na rede de esgoto pra vir pro lado da cidade, mas ele tirou pra baixo, falou que gastava menos dinheiro, e o governo estava pra mandar dinheiro. $O$ esgoto foi tudo num só. Essa caixinha aqui servia pra duas famílias, de uma casa já dava na do vizinho. Em vez de jogar na rua, cada um jogava sua rede de esgoto numa caixinha só. Se entope do vizinho vem na sua casa. até hoje o pessoal do jardim Gonzaga reclama disso. Aqui nós não temos queixa, porque o esgoto está ligado à rua.

27. Em sua opinião, que são os responsáveis por decidir o que está bom e o que deve ser mudado na área verde?

Eu apóio na turma da Universidade Federal, os engenheiros, junto com o prefeito que é um homem bem estudado e pode fazer isto aí.

28. Você tem alguma sugestão para mudança ? O que você gostaria que fosse feito na área verde?

eu acho que tinha que tirar aquela rede de esgoto de dentro da mata pra restaurar a água, e aí, restaurando a água, a mata vai sobreviver, porque vai tirar aquela sujeira, vai matar os micróbios, vai sobreviver e conservar uma água limpa, aí depois eu acho que acontecendo isso, aí podia restaurar o bairro, melhorar a iluminação, rede de esgoto, tratamento, que tem muitos que não tem galeria. Falta asfalto, mais árvore, árvores mais adequadas. A mata não deve ser loteada, cercada sim pra conservá-la, deveria ter uma ponte pra atravessar.

29. Gostaria de participar de um encontro sobre propostas para recuperação das áreas degradadas do seu bairro e do entorno ? $100 \%$ responderam sim

30. Qual a sua opinião sobre esta conversa? 
ANEXO 3: Mapa Mental.

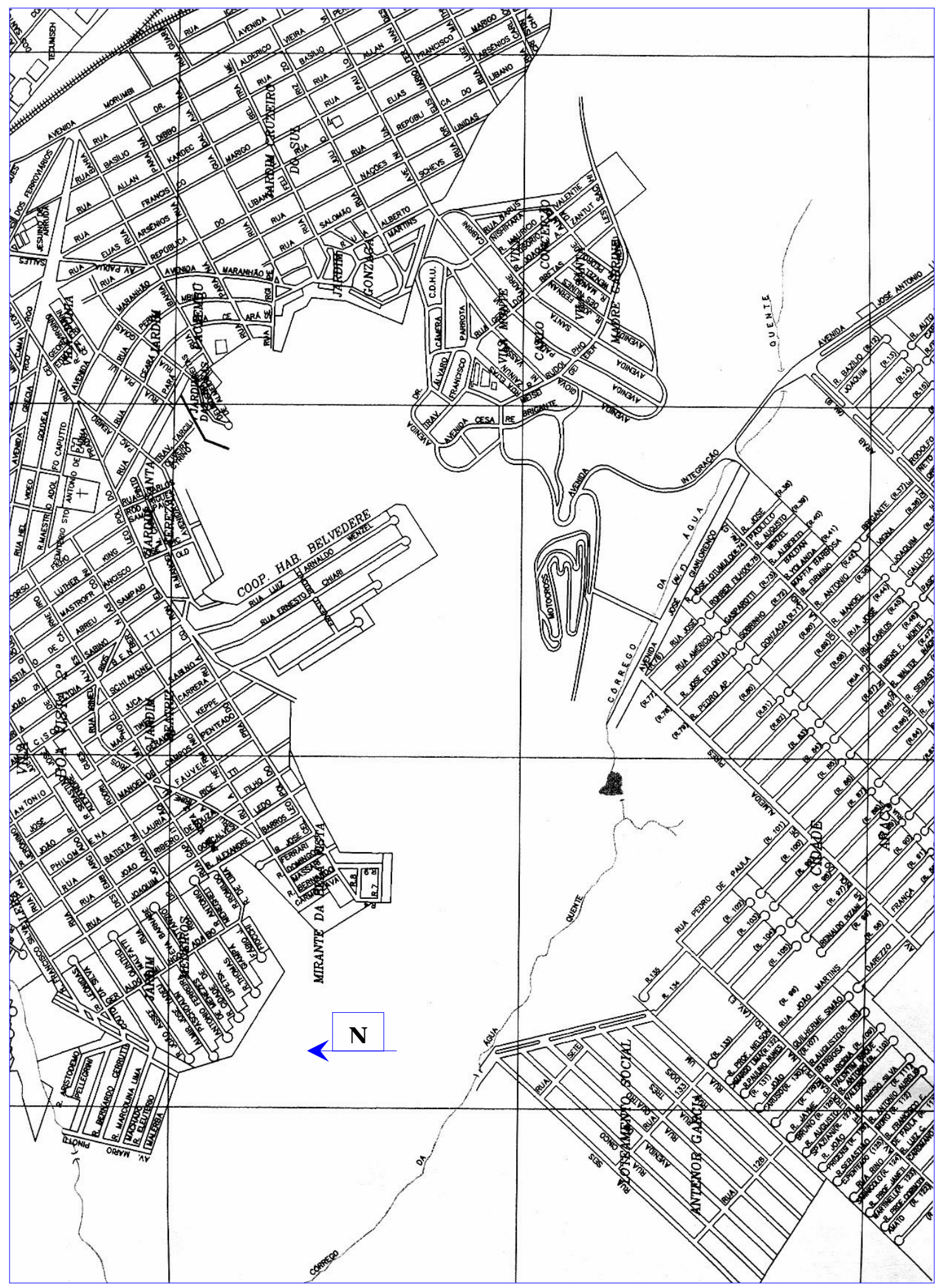

Detalhe do mapa da cidade de São Carlos utilizado como mapa mental nas escolas. Fonte: Prefeitura Municipal de São Carlos (2000) (modificado). 


\section{ANEXO 4: QUESTIONÁRIO}

Nome:

Idade:

Local de nascimento:

Endereço: Bairro:

Tempo de residência no local:

Escola: Série:

Obs: As questões abaixo foram transmitidas oralmente uma de cada vez, para que as subseqüentes não influenciassem nas respostas das anteriores.

1) Observando o mapa mental, descreva o que existe no espaço vazio entre os bairros.

2) O que você observa no trajeto entre sua casa e a escola?

3) Existe alguma vegetação em seu bairro? Você já visitou?

4) O que você já viu ou imagina que exista na área verde próxima ao bairro em que está inserida sua escola?

5) Quem são (as)os responsáveis pela atual situação da área verde existente próximo à sua escola, e quem deve decidir o que deveria ser feito naquele local?

6) Conte o que a área verde próxima ao seu bairro e/ou à sua escola significa para você e o que você gostaria que fosse feito naquele local. 
ANEXO 5: Maquete da MCAQ utilizada nas intervenções educativas.
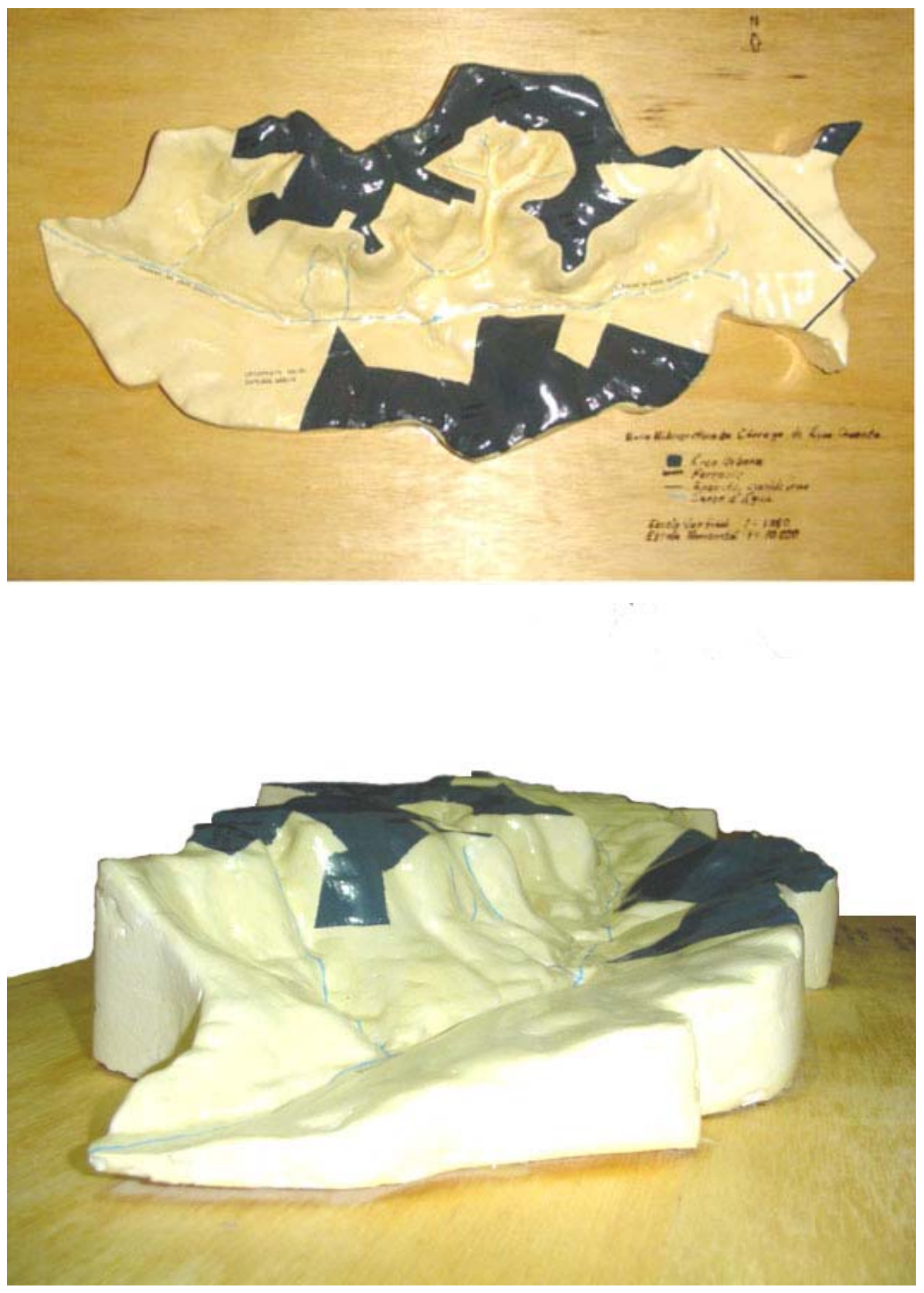
ANEXO 6: Avifauna da MCAQ. Nomenclatura científica e popular de acordo com Sick (1997). Fonte: Tóro-Tonissi, 2002.

\begin{tabular}{|c|c|c|c|}
\hline ORDEM/Família/Espécie & Nome popular & Dieta $^{1}$ & Status migratório $^{2}$ \\
\hline \multicolumn{4}{|l|}{ CICONIIFORMES } \\
\hline \multicolumn{4}{|l|}{ Cathartidae } \\
\hline Coragyps atratus & Urubu-de-cabeça-preta & NECR & $\mathrm{R}$ \\
\hline \multicolumn{4}{|l|}{ FALCONIFORMES } \\
\hline \multicolumn{4}{|l|}{ Accipitridae } \\
\hline Rupornis magnirostris & Gavião-carijó & CAR & $\mathrm{R}$ \\
\hline \multicolumn{4}{|l|}{ Falconidae } \\
\hline Milvago chimachima & Carrapateiro & CAR & $\mathrm{R}$ \\
\hline Polyborus plancus & Caracará & CAR & $\mathrm{R}$ \\
\hline \multicolumn{4}{|l|}{ CHARADRIIFORMES } \\
\hline \multicolumn{4}{|l|}{ Charadriidae } \\
\hline Vanellus chilensis & Quero-quero & INS & $\mathrm{R}$ \\
\hline \multicolumn{4}{|l|}{ COLUMBIFORMES } \\
\hline \multicolumn{4}{|l|}{ Columbidae } \\
\hline Columba livia domestica & Pombo doméstico & GRA & $\mathrm{R}$ \\
\hline Columba picazuro & Asa-branca & FRU/GRA & $\mathrm{R}$ \\
\hline Zenaida auriculata & Avoante & GRA & $\mathrm{R}$ \\
\hline Columbina talpacoti & Rolinha & GRA & $\mathrm{R}$ \\
\hline Leptotila rufaxilla & Gemedeira & FRU & $\mathrm{R}$ \\
\hline \multicolumn{4}{|l|}{ PSITTACIFORMES } \\
\hline \multicolumn{4}{|l|}{ Psittacidae } \\
\hline Aratinga leucophthalmus & Periquitão-maracanã & FRU & $\mathrm{R}$ \\
\hline Brotogeris chiriri & $\begin{array}{l}\text { Periquito-de-encontro- } \\
\text { amarelo }\end{array}$ & FRU & $\mathrm{R}$ \\
\hline \multicolumn{4}{|l|}{ CUCULIFORMES } \\
\hline \multicolumn{4}{|l|}{ Cuculidae } \\
\hline Crotophaga ani & Anu-preto & INS & $\mathrm{R}$ \\
\hline Guira guira & Anu-branco & INS & $\mathrm{R}$ \\
\hline \multicolumn{4}{|l|}{ STRIGIFORMES } \\
\hline \multicolumn{4}{|l|}{ Strigidae } \\
\hline Speotyto cunicularia & Coruja-do-campo & INS/CAR & $\mathrm{R}$ \\
\hline \multicolumn{4}{|l|}{ APODIFORMES } \\
\hline \multicolumn{4}{|l|}{ Trochilidae } \\
\hline Phaethornis pretrei & $\begin{array}{l}\text { Rabo-branco-de-sobre- } \\
\text { amarelo }\end{array}$ & NEC & $\mathrm{R}$ \\
\hline Eupetomena macroura & Tesourão & NEC & $\mathrm{R}$ \\
\hline
\end{tabular}




\begin{tabular}{|c|c|c|c|}
\hline \multicolumn{4}{|c|}{ ANEXO 6 Avifauna da MCAQ (continuação). } \\
\hline ORDEM/Família/Espécie & Nome popular & Dieta $^{1}$ & Status migratório $^{2}$ \\
\hline Colibri serrirostris & Beija-flor-de-orelha-violeta & NEC & $\mathrm{R}$ \\
\hline Amazilia lactea & Beija-flor-de-peito-azul & NEC & $\mathrm{R}$ \\
\hline \multicolumn{4}{|l|}{ PICIFORMES } \\
\hline \multicolumn{4}{|l|}{ Picidae } \\
\hline Picumnus albosquamatus & Pica-pau-anão-escamado & INS & $\mathrm{R}$ \\
\hline Colaptes campestris & Pica-pau-do-campo & INS & $\mathrm{R}$ \\
\hline Veniliornis passerinus & Pica-pauzinho anão & INS & $\mathrm{R}$ \\
\hline \multicolumn{4}{|l|}{ PASSERIFORMES } \\
\hline \multicolumn{4}{|l|}{ Formicariidae } \\
\hline Tararba major & Choró boi & INS & $\mathrm{R}$ \\
\hline Thamnophilus doliatus & Choca-barrada & INS & $\mathrm{R}$ \\
\hline \multicolumn{4}{|l|}{ Furnariidae } \\
\hline Furnarius rufus & João-de-barro & INS & $\mathrm{R}$ \\
\hline Synallaxis frontalis & Petrin & INS & $\mathrm{R}$ \\
\hline \multicolumn{4}{|l|}{ Tyrannidae } \\
\hline Camptostoma obsoletum & Risadinha & INS & $\mathrm{R}$ \\
\hline Elaenia flavogaster & Guaracava & ONI & $\mathrm{R}$ \\
\hline Serpophaga subcristata & Alegrinho & INS & $\mathrm{R}$ \\
\hline Todirostrum cinereum & Reloginho & INS & $\mathrm{R}$ \\
\hline Myiophobus fasciatus & Filipe & INS & $\mathrm{R}$ \\
\hline Pyrocephalus rubinus & Verão & INS & $\mathrm{M}$ \\
\hline Myiarchus ferox & Maria-cavaleira & INS & $\mathrm{R}$ \\
\hline Pitangus sulphuratus & Bentevi & ONI & $\mathrm{R}$ \\
\hline Megarynchus pitangua & Bentevi-de-bico-chato & ONI & $\mathrm{R}$ \\
\hline Myiodinastes maculatus & Bentevi rajado & ONI & $\mathrm{M}$ \\
\hline Tyrannus melancholicus & Suiriri & ONI & $\mathrm{M}$ \\
\hline \multicolumn{4}{|l|}{ Hyrundinidae } \\
\hline Notiochelidon cyanoleuca & Andorinha-pequena-de-casa & INS & $\mathrm{R}$ \\
\hline \multicolumn{4}{|l|}{ Corvidae } \\
\hline Cyanocorax cristatellus & Gralha-do-campo & ONI & $\mathrm{R}$ \\
\hline \multicolumn{4}{|l|}{ Troglodytidae } \\
\hline Thryothorus leucotis & Garrinchão & INS & $\mathrm{R}$ \\
\hline Troglodytes aedon & Corruíra & INS & $\mathrm{R}$ \\
\hline \multicolumn{4}{|l|}{ Muscicapidae } \\
\hline Turdus leucomelas & Sabiá-barranco & ONI & $\mathrm{R}$ \\
\hline Vireonidae & & & \\
\hline
\end{tabular}




\begin{tabular}{|c|c|c|c|}
\hline \multicolumn{4}{|c|}{ ANEXO 6: Avifauna da MCAQ (continuação). } \\
\hline ORDEM/Família/Espécie & Nome popular & Dieta $^{1}$ & Status migratório $^{2}$ \\
\hline Cyclarhis gujanensis & Pitiguari & ONI & $\mathrm{R}$ \\
\hline Vireo olivaceus & Juruviara & ONI & $\mathrm{M}$ \\
\hline \multicolumn{4}{|l|}{ Emberizidae } \\
\hline Geothlypis aequinoctialis & Pia-cobra & INS & $\mathrm{R}$ \\
\hline Basileuterus flaveolus & Canário-do-mato & INS & $\mathrm{R}$ \\
\hline $\begin{array}{l}\text { Basileuterus culicivorus } \\
\text { hypoleucus }\end{array}$ & Pula-pula & INS & $\mathrm{R}$ \\
\hline Coereba flaveola & Cambacica & NEC & $\mathrm{R}$ \\
\hline Thlypopsis sordida & Canário-sapé & INS & M \\
\hline Nemosia pileata & Saíra-de-chapéu-preto & ONI & $\mathrm{R}$ \\
\hline Ramphocelus carbo & Pipira vermelha & ONI & $\mathrm{R}$ \\
\hline Thraupis sayaca & Sanhaço-cinzento & ONI & $\mathrm{R}$ \\
\hline Tangara cayana & Saíra-amarelo & ONI & $\mathrm{R}$ \\
\hline Tersina viridis & Saí-andorinha & ONI & $\mathrm{M}$ \\
\hline Zonotrichia capensis & Tico-tico & GRA & $\mathrm{R}$ \\
\hline Volatinia jacarina & Tiziu & GRA & $\mathrm{R}$ \\
\hline Sporophila caerulescens & Coleirinho & GRA & $\mathrm{R}$ \\
\hline \multicolumn{4}{|l|}{ Passeridae } \\
\hline Passer domesticus & Pardal & GRA & $\mathrm{R}$ \\
\hline
\end{tabular}

${ }^{1}$ INS = Insetívoro; ONI = Onívoro; FRU = Frugívoro; GRA = Granívoro; NEC = Nectarívoro; NECR = Necrófago; CAR = Carnívoro (Willis, 1979; Motta-Junior, 1990).

${ }^{2} \mathrm{R}=$ Residente; $\mathrm{M}=$ Migratório (Motta-Junior \& Vasconcellos, 1996). 
ANEXO 7:

TABELA 5: Espécies vegetais encontradas na área verde da MCAQ. Fonte: TÓRO-TONISSI e TONISSI (2002).

\begin{tabular}{|l|l|}
\hline ESPÉCIES DO CERRADO \\
\hline Espécie & Nome Popular \\
\hline Stryphnodendron adstringens Benth & Barbatimão \\
\hline Caryocar brasiliense Camb & Pequi \\
\hline Dalbergia miscolobium Benth & Sapuvuçu \\
\hline Solanum lycocarpum St. Hill. & Lobeira \\
\hline Xylopia aromatica Mart. & Pimenta-de-macaco \\
\hline
\end{tabular}

\section{ESPÉCIES DA FLORESTA DE TRANSIÇÃO}

\begin{tabular}{|l|l|}
\hline Espécie & Nome Popular \\
\hline Qualea jundiahy Warm & Pau-terra-jundiaí \\
\hline Copaifera langsdorffii Desf & Copaíba \\
\hline Pseudobombax longiflorum A. Rob. & Embiruçu \\
\hline Tapirira sp. & Peito-de-pombo \\
\hline Andira sp. & Angelim \\
\hline Terminalia brasiliensis Camb. & Amarelinho \\
\hline Lamanonia ternata Vell. & Pau-de-cangalha \\
\hline Qualea grandiflora Mart. & Pau-terra \\
\hline Machaerium villosum Vog. & Jacarandá-paulista \\
\hline Astronium graveolensi Jacq. & Guarita \\
\hline Luehea grandiflora Mart. et Zucc. & Açoita-cavalo \\
\hline Lafoensia pacari St. Hill. & Dedaleiro \\
\hline Anadenanthera falcata Spreng & Angico-do-cerrado \\
\hline Tocoiena sp & Marmelo-do-cerrado \\
\hline Platypodium elegans Vog. & Amendoim-do-campo \\
\hline Bowdichia virgilioides Kunth. & Sucupira-preta \\
\hline Xylopia brasiliensis Spreng. & Pindaíbuna \\
\hline Didymopanix vinnosum & Mandioqueiro-anão \\
\hline Vitex sp & Tarumã \\
\hline & \\
\hline
\end{tabular}




\section{ANEXO 8}

Valores de temperatura $\left({ }^{\circ} \mathrm{C}\right)$ das amostras de água da microbacia do córrego da Água Quente, São Carlos, SP.

\begin{tabular}{|c|c|c|c|c|c|c|c|c|c|c|c|c|c|}
\hline \multirow{2}{*}{$\begin{array}{l}\text { Temperatura } \\
\begin{array}{|l}\text { Pontos } \\
\end{array}\end{array}$} & \multicolumn{13}{|c|}{ MESES } \\
\hline & dez/01 & jan/02 & fev/02 & $\mathrm{mar} / 02$ & $\mathrm{abr} / 02$ & mai/02 & jun/02 & jul/02 & ago/02 & set/02 & out/02 & nov/02 & $\mathrm{dez} / 02$ \\
\hline N Vale & & & & 23,1 & 23,0 & 20,2 & 21,1 & 18,9 & 21,2 & 21,8 & 23,4 & 23,1 & 22,1 \\
\hline AQ Aracy & 25,9 & 21,8 & 20,6 & 24,0 & 24,3 & 20,4 & 21,5 & 18,7 & 22,2 & 23,3 & 25,0 & 24,0 & 22,0 \\
\hline AQ Belvedere & 19,4 & 23,4 & 20,6 & 24,7 & 21,5 & 16,7 & 17,4 & 14,3 & 19,2 & 19,0 & 22,0 & 18,6 & 21,9 \\
\hline AQ Gonzaga & 19,1 & 21,6 & 20,7 & 24,8 & 21,3 & 17,5 & 17,7 & 14,7 & 19,3 & 18,9 & 21,2 & 18,1 & 21,1 \\
\hline AQ Antenor & 24,3 & 22,2 & 20,7 & 27,9 & 25,9 & 19,9 & 21,5 & 19,2 & 21,8 & 22,8 & 27,1 & 25,3 & 22,5 \\
\hline Foz & & & & & 23,4 & 18,1 & 19,4 & 16,7 & 20,1 & 21,1 & 24,7 & 22,1 & 21,9 \\
\hline
\end{tabular}


Anexo 9

Valores de algumas variáveis físicas e químicas das amostras de água da microbacia do córrego da Água Quente, São Carlos, SP (pH e Turbidez -NTU).

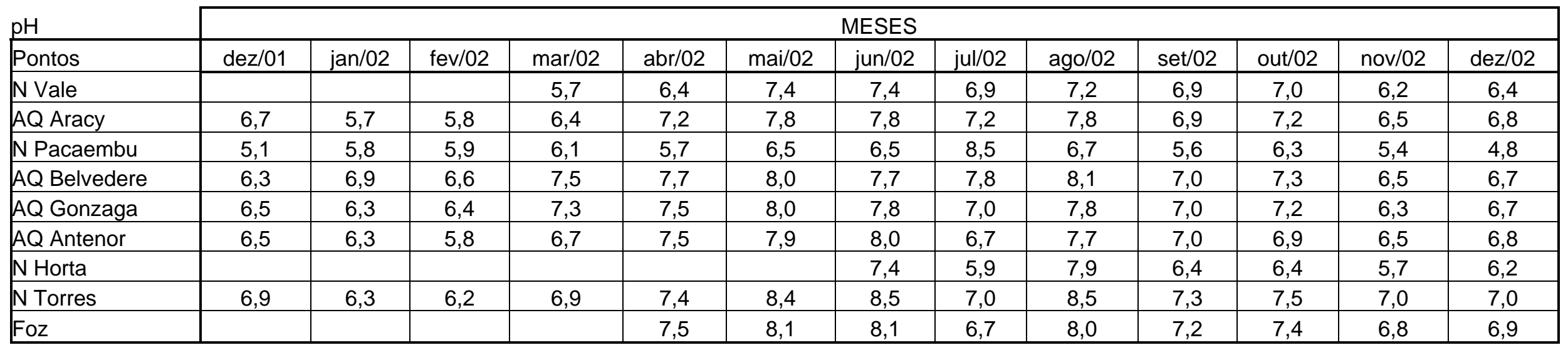

\begin{tabular}{|l|c|c|c|c|c|c|c|c|c|c|c|c|c|}
\cline { 2 - 13 } turbidez & \multicolumn{10}{|c|}{ MESES } \\
\hline Pontos & dez/01 & jan/02 & fev/02 & mar/02 & abr/02 & mai/02 & jun/02 & jul/02 & ago/02 & set/02 & out/02 & nov/02 & dez/02 \\
\hline N Vale & & & & 23,0 & 12,0 & 10,0 & 6,0 & 7,0 & 24,0 & 36,0 & 197,0 & 177,0 & 62,0 \\
\hline AQ Aracy & 134,0 & 461,0 & 461,0 & 105,0 & 136,0 & 166,0 & 158,0 & 96,0 & 105,0 & 179,0 & 144,0 & 322,0 & 130,0 \\
\hline N Pacaembu & 0,0 & 0,0 & 0,0 & 4,0 & 0,0 & 0,0 & 0,0 & 1,0 & 2,0 & 2,0 & 2,0 & 2,0 & 9,0 \\
\hline AQ Belvedere & 17,0 & 144,0 & 206,0 & 43,0 & 24,0 & 18,0 & 18,0 & 86,0 & 34,0 & 132,0 & 5,0 & 5,0 & 3,0 \\
\hline AQ Gonzaga & 46,0 & 140,0 & 125,0 & 109,0 & 59,0 & 29,0 & 72,0 & 84,0 & 33,0 & 38,0 & 61,0 & 337,0 & 49,0 \\
\hline AQ Antenor & 122,0 & 430,0 & 461,0 & 157,0 & 140,0 & 95,0 & 96,0 & 221,0 & 165,0 & 129,0 & 134,0 & 235,0 & 305,0 \\
\hline N Horta & & & & & & & 18,0 & 6,0 & 11,0 & 18,0 & 9,0 & 10,0 & 24,0 \\
\hline N Torres & 0,0 & 29,0 & 43,0 & 13,0 & 1,0 & 0,0 & 1,0 & 1,0 & 0,0 & 2,0 & 0,0 & 2,0 & 1,0 \\
\hline Foz & & & & & 172,0 & 127,0 & 115,0 & 105,0 & 164,0 & 131,0 & 100,0 & 183,0 & 191,0 \\
\hline
\end{tabular}




\section{ANEXO 10}

Valores de algumas variáveis físicas e químicas das amostras de água da microbacia do córrego da Água Quente, São Carlos, SP (condutividade - $\mu$ S/cm e oxigênio dissolvido - mg/L).

\begin{tabular}{|c|c|c|c|c|c|c|c|c|c|c|c|c|c|}
\hline \multirow{2}{*}{ 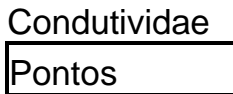 } & \multicolumn{13}{|c|}{ MESES } \\
\hline & $\mathrm{dez} / 01$ & jan/02 & fev/02 & $\mathrm{mar} / 02$ & $\mathrm{abr} / 02$ & mai/02 & jun/02 & jul/02 & ago/02 & set/02 & out/02 & nov/02 & dez/02 \\
\hline N Vale & & & & 12,0 & 12,0 & 11,0 & 11,0 & 11,0 & 11,0 & 11,0 & 24,0 & 10,0 & 12,0 \\
\hline AQ Aracy & 57,0 & 39,0 & 25,0 & 107,0 & 118,0 & 112,0 & 135,0 & 138,0 & 65,0 & 139,0 & 120,0 & 72,0 & 136,0 \\
\hline AQ Belvedere & 192,0 & 196,0 & 68,0 & 412,0 & 290,0 & 306,0 & 267,0 & 266,0 & 254,0 & 307,0 & 268,0 & 252,0 & 290,0 \\
\hline AQ Gonzaga & 315,0 & 121,0 & 59,0 & 390,0 & 228,0 & 257,0 & 275,0 & 273,0 & 162,0 & 251,0 & 280,0 & 337,0 & 324,0 \\
\hline AQ Antenor & 208,0 & 220,0 & 65,0 & 185,0 & 195,0 & 183,0 & 207,0 & 161,0 & 205,0 & 215,0 & 189,0 & 197,0 & 215,0 \\
\hline Foz & & & & & 149,0 & 139,0 & 172,0 & 164,0 & 151,0 & 154,0 & 152,0 & 172,0 & 160,0 \\
\hline
\end{tabular}

\begin{tabular}{|c|c|c|c|c|c|c|c|c|c|c|c|c|c|}
\hline \multirow{2}{*}{$\begin{array}{l}\text { Oxigênio } \\
\text { Dissolvido } \\
\text { Pontos }\end{array}$} & \multicolumn{13}{|c|}{ MESES } \\
\hline & dez/01 & $\mathrm{jan} / 02$ & $\mathrm{fev} / 02$ & $\mathrm{mar} / 02$ & abr/02 & mai/02 & jun/02 & jul/02 & ago/02 & set/02 & out/02 & nov/02 & $\mathrm{dez} / 02$ \\
\hline N Vale & & & & 8,1 & 8,3 & 8,3 & 9,8 & 8,6 & 8,6 & 8,3 & 7,2 & 8,8 & 9,4 \\
\hline AQ Aracy & 5,9 & 7,8 & 8,0 & 6,4 & 6,3 & 6,9 & 6,6 & 6,6 & 7,6 & 6,7 & 5,8 & 8,8 & 7,4 \\
\hline N Pacaembu & 5,5 & 5,1 & 5,0 & 5,8 & 6,0 & 6,1 & 5,6 & 6,8 & 6,4 & 7,3 & 5,7 & 5,6 & 9,0 \\
\hline AQ Belvedere & 2,0 & 7,5 & 7,9 & 1,4 & 1,2 & 2,3 & 3,4 & 3,4 & 4,2 & 9,0 & 2,4 & 4,2 & 3,0 \\
\hline AQ Gonzaga & 1,7 & 6,0 & 7,3 & 0,7 & 1,5 & 2,1 & 0,2 & 5,1 & 3,6 & 2,0 & 2,0 & 1,7 & 1,1 \\
\hline AQ Antenor & 4,9 & 7,1 & 7,5 & 5,3 & 5,0 & 6,1 & 4,7 & 2,2 & 5,9 & 4,8 & 3,9 & 5,1 & 6,3 \\
\hline N Horta & & & & & & & 4,6 & 5,3 & 1,3 & 0,7 & 2,4 & 0,6 & 0,6 \\
\hline N Torres & 8,8 & 7,2 & 7,9 & 6,3 & 7,7 & 7,7 & 8,9 & 8,5 & 7,6 & 8,5 & 7,8 & 8,5 & 7,5 \\
\hline Foz & & & & & 7,0 & 7,5 & 6,6 & 7,8 & 7,4 & 6,9 & 5,6 & 7,5 & 6,9 \\
\hline
\end{tabular}


ANEXO 11

Valores de algumas variáveis físicas e químicas das amostras de água da microbacia do Córrego da Água Quente, São Carlos, SP (nitrogênio orgânico total $\mathrm{mg} / \mathrm{L}$ e nitrato - $\mu \mathrm{g} / \mathrm{L}$ ).

\begin{tabular}{|c|c|c|c|c|c|c|c|c|c|c|c|c|c|}
\hline $\begin{array}{l}\text { Nitrogênio } \\
\text { Orgânico Total } \\
\text { Pontos }\end{array}$ & \multicolumn{13}{|c|}{ MESES } \\
\hline N Vale & & & & 5,3 & 0,6 & 2,1 & 1,0 & 0,8 & 3,9 & 1,0 & 1,5 & 0,2 & 0,0 \\
\hline N Pacaembu & 0,1 & 0,4 & 0,6 & 0,0 & 0,1 & 1,2 & 1,4 & 0,1 & 1,3 & 0,6 & 0,4 & 0,4 & 0,3 \\
\hline AQ Belvedere & 21,5 & 13,7 & 6,4 & 0,5 & 33,5 & 45,7 & 38,9 & 46,0 & 35,4 & 20,3 & 20,8 & 34,9 & 31,7 \\
\hline AQ Gonzaga & 41,5 & 17,3 & 7,7 & 11,4 & 46,8 & 44,6 & 56,2 & 52,5 & 32,7 & 21,4 & 24,0 & 38,9 & 42,0 \\
\hline N Torres & 0,6 & 2,6 & 3,2 & 11,9 & 1,5 & 1,8 & 1,8 & 1,1 & 2,7 & 0,9 & 0,6 & 0,1 & 0,3 \\
\hline Foz & & & & & 13,5 & 12,4 & 25,6 & 20,6 & 20,3 & 19,0 & 23,2 & 17,7 & 15,2 \\
\hline
\end{tabular}

\begin{tabular}{|c|c|c|c|c|c|c|c|c|c|c|c|c|}
\hline \multicolumn{13}{|c|}{ MESES } \\
\hline & & & 262,3 & 209,4 & 155,3 & 136,8 & 136,0 & 459,9 & 577,7 & 474,7 & 502,4 & 481,4 \\
\hline 8196,4 & 1806,4 & 1836,0 & 1496,0 & 5366,4 & 3634,4 & 4001,6 & 3226,2 & 943,8 & 10427,0 & 1035,9 & 10133,0 & 8191,7 \\
\hline 69,0 & 347,3 & 197,9 & 48,0 & 75,9 & 29,6 & 13,3 & 179,5 & 46,9 & 30,9 & 29,3 & 23,9 & 27,5 \\
\hline 35,6 & 183,2 & 133,1 & 31,6 & 68,1 & 19,1 & 19,6 & 37,9 & 57,8 & 29,6 & 35,1 & 113,1 & 17,6 \\
\hline 6526,0 & 952,4 & 563,1 & 1079,8 & 2447,0 & 1793,9 & 2002,5 & 1171,2 & 422,7 & 6631,0 & 8040,6 & 2138,9 & 9348,1 \\
\hline & & & & & & 45,8 & 29,5 & 32,5 & 58,4 & 63,4 & 23,6 & 46,8 \\
\hline
\end{tabular}




\section{ANEXO 12}

Valores de algumas variáveis físicas e químicas das amostras de água da sub-bacia do Córrego da Água Quente, São Carlos, $\mathrm{SP}$ (nitrito - $\mathrm{NO}_{2}{ }^{-}$- $\mu \mathrm{g} / \mathrm{L}$ e amônio - $\mu g / L$ ).

\begin{tabular}{|c|c|c|c|c|c|c|c|c|c|c|c|c|c|}
\hline \multirow{2}{*}{$\begin{array}{l}\text { Nitrito } \\
\text { Pontos }\end{array}$} & \multicolumn{13}{|c|}{ MESES } \\
\hline & dez/01 & $\mathrm{jan} / 02$ & fev/02 & mar/02 & $\mathrm{abr} / 02$ & mai/02 & jun/02 & jul/02 & ago/02 & set/02 & out/02 & nov/02 & $\mathrm{dez} / 02$ \\
\hline N Vale & & & & 3,2 & 5,2 & 3,2 & 4,4 & 2,7 & 3,2 & 4,7 & 3,2 & 4,1 & 3,8 \\
\hline AQ Aracy & 32,5 & 7,1 & 23,8 & 15,8 & 22,6 & 15,2 & 19,6 & 27,8 & 13,3 & 16,3 & 13,9 & 15,4 & 18,6 \\
\hline N Pacaembu & 1,0 & 4,8 & 3,1 & 2,1 & 1,8 & 2,4 & 3,7 & 0,7 & 1,6 & 1,7 & 2,3 & 1,4 & 4,5 \\
\hline AQ Belvedere & 20,3 & 40,9 & 27,0 & 18,8 & 13,0 & 15,2 & 14,2 & 6,7 & 21,9 & 13,9 & 11,6 & 9,5 & 12,4 \\
\hline AQ Gonzaga & 24,5 & 28,8 & 24,1 & 28,1 & 19,2 & 25,0 & 19,3 & 15,3 & 26,4 & 22,3 & 21,4 & 16,2 & 23,4 \\
\hline AQ Antenor & 80,1 & 34,6 & 19,7 & 54,6 & 55,8 & 71,8 & 72,2 & 54,7 & 92,3 & 83,6 & 66,2 & 127,5 & 98,1 \\
\hline N Horta & & & & & & & 10,0 & 4,9 & 11,4 & 36,4 & 4,9 & 3,6 & 4,6 \\
\hline N Torres & 5,5 & 32,2 & 29,9 & 460,7 & 6,4 & 2,6 & 4,0 & 2,6 & 7,8 & 3,7 & 4,5 & 3,8 & 1,4 \\
\hline Foz & & & & & 72,0 & 54,5 & 52,8 & 43,5 & 63,2 & 64,7 & 63,6 & 88,6 & 61,9 \\
\hline
\end{tabular}

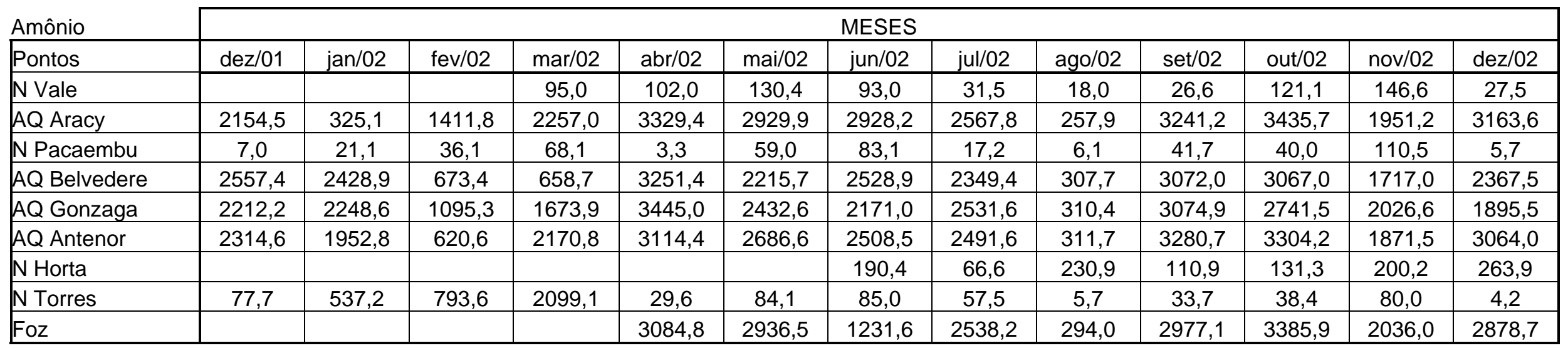


ANEXO 13

Valores de algumas variáveis físicas e químicas das amostras de água da microbacia do Córrego da Água Quente, São Carlos, SP [fósforo total - pg/L e fosfato total dissolvido $-\mu \mathrm{g} / \mathrm{L}$ ).

\begin{tabular}{|c|c|c|c|c|c|c|c|c|c|c|c|c|c|}
\hline \multirow{2}{*}{$\begin{array}{l}\text { Fósforo total } \\
\text { Pontos }\end{array}$} & \multicolumn{13}{|c|}{ MESES } \\
\hline & $\mathrm{dez} / 01$ & $\mathrm{jan} / 02$ & fev/02 & mar/02 & abr/02 & mai/02 & jun/02 & jul/02 & ago/02 & set/02 & out/02 & nov/02 & $\mathrm{dez} / 02$ \\
\hline N Vale & & & & 52,4 & 110,0 & 322,7 & 187,5 & 27,1 & 39,8 & 79,9 & 267,3 & 117,7 & 87,3 \\
\hline N Pacaembu & 34,5 & 69,0 & 83,8 & 63,6 & 47,8 & 33,6 & 169,5 & 52,5 & 15,2 & 39,2 & 54,4 & 36,8 & 213,6 \\
\hline AQ Belvedere & 1133,9 & 5141,3 & 432,1 & 3245,7 & 1697,1 & 1892,1 & 1704,3 & 1578,5 & 1477,0 & 3456,8 & 2987,4 & 1422,4 & 1568,5 \\
\hline AQ Gonzaga & 1783,8 & 1206,0 & 4626,0 & 2978,0 & 1915,8 & 1703,0 & 1965,3 & 1836,0 & 1376,9 & 2645,6 & 3245,5 & 1825,5 & 1771,5 \\
\hline N Torres & 1043,1 & 425,8 & 578,3 & 1131,6 & 291,7 & 836,8 & 489,2 & 169,5 & 134,7 & 127,7 & 194,8 & 191,3 & 167,9 \\
\hline Foz & & & & & 418,8 & 314,6 & 658,0 & 872,7 & 362,1 & 846,3 & 1019,8 & 365,5 & 184,7 \\
\hline
\end{tabular}

\begin{tabular}{|c|c|c|c|c|c|c|c|c|c|c|c|c|c|}
\hline $\begin{array}{l}\text { Fosfato total } \\
\text { dissolvido } \\
\text { Pontos }\end{array}$ & \multicolumn{13}{|c|}{ MESES } \\
\hline N Vale & & & & 15,7 & 25,8 & 23,9 & 25,5 & 24,8 & 17,8 & 17,7 & 35,9 & 25,5 & 22,4 \\
\hline N Pacaembu & 14,6 & 15,6 & 25,3 & 21,0 & 17,0 & 13,8 & 21,9 & 29,9 & 15,0 & 14,7 & 27,1 & 11,7 & 96,6 \\
\hline AQ Belvedere & 820,5 & 566,4 & 263,7 & 2794,9 & 1261,7 & 1560,6 & 1544,3 & 1308,1 & 1025,2 & 2911,0 & 2642,1 & 1040,5 & 1144,2 \\
\hline AQ Gonzaga & 1238,2 & 586,5 & 232,2 & 2914,9 & 1283,7 & 1633,5 & 1676,1 & 1498,1 & 947,2 & 2465,4 & 2719,8 & 1231,8 & 1247,5 \\
\hline N Torres & 203,2 & 204,6 & 215,4 & 909,1 & 121,7 & 147,5 & 182,5 & 130,5 & 128,5 & 123,0 & 119,1 & 133,6 & 21,7 \\
\hline Foz & & & & & 202,6 & 164,7 & 280,4 & 276,9 & 120,5 & 329,7 & 410,3 & 135,3 & 157,5 \\
\hline
\end{tabular}


ANEXO 14

Valores de fosfato inorgânico ( $\mu \mathrm{g} / \mathrm{L})$ das amostras de água da microbacia do Córrego da Água Quente, São Carlos, SP

\begin{tabular}{|c|c|c|c|c|c|c|c|c|c|c|c|c|c|}
\hline Pontos & dez/01 & jan/02 & $\mathrm{fev} / 02$ & $\mathrm{mar} / 02$ & $\mathrm{abr} / 02$ & mai/02 & jun/02 & jul/02 & ago/02 & set/02 & out/02 & nov/02 & dez/02 \\
\hline AQ Aracy & 132,8 & 24,9 & 42,3 & 300,3 & 683,2 & 394,2 & 822,1 & 899,3 & 207,9 & 840,7 & 721,6 & 303,9 & 484,3 \\
\hline N Pacaembu & 8,1 & 14,5 & 19,1 & 14,4 & 14,0 & 7,5 & 10,6 & 22,3 & 10,8 & 7,2 & 15,9 & 8,1 & 84,5 \\
\hline AQ Belvedere & 795,4 & 392,2 & 196,2 & 2331,1 & 1217,4 & 1422,6 & 1396,0 & 1181,9 & 984,2 & 2066,5 & 2286,8 & 992,6 & 1140,1 \\
\hline N Horta & & & & & & & 24,7 & 11,5 & 170,7 & 193,1 & 27,7 & 204,3 & 238,3 \\
\hline N Torres & 124,4 & 139,4 & 197,7 & 819,3 & 105,9 & 107,5 & 103,6 & 114,8 & 113,9 & 92,6 & 102,1 & 102,8 & 15,9 \\
\hline Foz & & & & & 154,5 & 101,5 & 187,1 & 222,8 & 98,0 & 265,7 & 356,7 & 93,8 & 112,1 \\
\hline
\end{tabular}


ANEXO 15

Saberes de um morador da microbacia sobre espécies vegetais existentes na área verde e suas propriedades medicinais.

\begin{tabular}{|c|c|c|c|c|}
\hline \multicolumn{2}{|c|}{ Descrição do Sr. Antônio } & \multicolumn{3}{|c|}{ Descrição da literatura } \\
\hline $\begin{array}{l}\text { Nome } \\
\text { popular }\end{array}$ & Usos & $\begin{array}{l}\text { Nome } \\
\text { popular }\end{array}$ & Nome científico & Usos \\
\hline $\begin{array}{l}\text { Açoita- } \\
\text { cavalo }\end{array}$ & Canga de boi & $\begin{array}{l}\text { Açoita- } \\
\text { cavalo }\end{array}$ & $\begin{array}{l}\text { Luehea } \\
\text { paniculata }\end{array}$ & $\begin{array}{l}\text { Peças curvadas } \\
\text { como selas e hélices } \\
\text { de avião }\end{array}$ \\
\hline $\begin{array}{l}\text { Alecrim- } \\
\text { do-mato }\end{array}$ & Vassoura & $\begin{array}{l}\text { Alecrim-do- } \\
\text { campo, } \\
\text { vassourinha }\end{array}$ & $\begin{array}{c}\text { Asteraceae } \\
\text { Baccharis } \\
\text { dracunculifolia }\end{array}$ & $\begin{array}{lr}\text { Produção } & \text { de } \\
\text { própolis } & \text { verde, } \\
\text { utilizado } & \text { em } \\
\text { medicamentos } & \\
\end{array}$ \\
\hline Amarelinho & $\begin{array}{l}\text { Chá da raiz mais } \\
\text { ovo e leite para } \\
\text { fortificar o } \\
\text { sangue }\end{array}$ & $\begin{array}{l}\text { Amarelinha, } \\
\text { taiúva }\end{array}$ & $\begin{array}{l}\text { Maclura } \\
\text { tinctoria }\end{array}$ & $\begin{array}{l}\text { Madeira } \\
\text { construções } \\
\text { externas, árvore } \\
\text { pioneira apropriada } \\
\text { para plantio em } \\
\text { áreas degradadas, } \\
\text { frutos apreciados } \\
\text { pela avifauna }\end{array}$ \\
\hline Ananás & $\begin{array}{l}\text { Alimento (fruto, } \\
\text { palmito) }\end{array}$ & $\begin{array}{l}\text { Ananás, } \\
\text { abacaxi-do- } \\
\text { cerrado }\end{array}$ & $\begin{array}{c}\text { Ananas } \\
\text { ananassoides }\end{array}$ & $\begin{array}{l}\text { Afecções da pele } \\
\text { (feridas, úlceras, } \\
\text { acnes, psoríase) }\end{array}$ \\
\hline $\begin{array}{l}\text { Angico- } \\
\text { roxo }\end{array}$ & $\begin{array}{c}\text { Chá da casca } \\
\text { para inflamação } \\
\text { no intestino } \\
\end{array}$ & & $\begin{array}{l}\text { Anadenanthera } \\
\text { falcata }\end{array}$ & \\
\hline Araruva & Madeira & $\begin{array}{l}\text { Araruva, } \\
\text { araribá }\end{array}$ & $\begin{array}{l}\text { Centrolobium } \\
\text { tomentosum }\end{array}$ & $\begin{array}{l}\text { Construção naval, } \\
\text { marcenaria }\end{array}$ \\
\hline Araticum & Alimento & $\begin{array}{l}\text { Araticum, } \\
\text { pinha-do- } \\
\text { cerrado } \\
\end{array}$ & $\begin{array}{c}\text { Annona } \\
\text { crassiflora }\end{array}$ & Alimento \\
\hline Assa-peixe & $\begin{array}{l}\text { Repelente para } \\
\text { piolho de } \\
\text { galinha }\end{array}$ & Assa-peixe & $\begin{array}{l}\text { Vernonia } \\
\text { polyanthes }\end{array}$ & $\begin{array}{l}\text { Chá das folhas e } \\
\text { raízes para gripe, } \\
\text { bronquite, tosse, } \\
\text { cálculo } \\
\text { renal,diurética, anti- } \\
\text { reumática }\end{array}$ \\
\hline $\begin{array}{l}\text { Barbatimão } \\
\text { macho }\end{array}$ & $\begin{array}{l}\text { Juntar com } \\
\text { quebrache para } \\
\text { Curtir couro }\end{array}$ & $\begin{array}{l}\text { Barbatimão- } \\
\text { falso }\end{array}$ & $\begin{array}{l}\text { Dimorphandra } \\
\text { mollis }\end{array}$ & $\begin{array}{lr}\text { Ornamental } & \mathrm{e} \\
\text { reflorestamento } & \text { de } \\
\text { áreas degradadas } & \end{array}$ \\
\hline $\begin{array}{l}\text { Barbatimão } \\
\text { fêmea }\end{array}$ & $\begin{array}{l}\text { Curtir couro, } \\
\text { chá da casca da } \\
\text { árvore para } \\
\text { estômago, pôr a } \\
\text { casca na chapa e } \\
\text { fazer o pó para } \\
\text { cicatrizar feridas }\end{array}$ & $\begin{array}{l}\text { Barbatimão, } \\
\text { barbatimão } \\
\text { verdadeiro }\end{array}$ & $\begin{array}{l}\text { Stryphnodendron } \\
\text { adstringens }\end{array}$ & $\begin{array}{l}\text { Empregado no } \\
\text { curturme. Decocto } \\
\text { da casca para } \\
\text { diarréia, hemorróida, } \\
\text { hemorragias, } \\
\text { conjuntivite, e como } \\
\text { cicatrizante }\end{array}$ \\
\hline Batata-da- & Alimento, batata & Jalapa-do- & Operculina alata & Asma juvenil, \\
\hline
\end{tabular}




\begin{tabular}{|c|c|c|c|c|}
\hline índia & para estômago & $\begin{array}{l}\text { Brasil, } \\
\text { batata-de- } \\
\text { purga }\end{array}$ & & $\begin{array}{l}\text { paralisias parciais } \\
\text { resultantes de AVC, } \\
\text { laxante, depurativa }\end{array}$ \\
\hline $\begin{array}{l}\text { Caju-do- } \\
\text { campo }\end{array}$ & Alimento & $\begin{array}{l}\text { Cajuzinho- } \\
\text { do-campo }\end{array}$ & $\begin{array}{l}\text { Anacardium } \\
\text { humile }\end{array}$ & $\begin{array}{l}\text { Chá das folhas e da } \\
\text { casca do caule para } \\
\text { diarréia, suco do } \\
\text { pseudofruto para } \\
\text { sífilis, infusão das } \\
\text { inflorescências para } \\
\text { tosse, diabete. }\end{array}$ \\
\hline Cambuí & & Cambuí & $\begin{array}{c}\text { Myrcia } \\
\text { multiflora }\end{array}$ & \\
\hline $\begin{array}{l}\text { Canela-de- } \\
\text { veado }\end{array}$ & & $\begin{array}{l}\text { Canela-de- } \\
\text { veado, osso- } \\
\text { de-burro }\end{array}$ & $\begin{array}{l}\text { Helietta } \\
\text { apiculata }\end{array}$ & $\begin{array}{l}\text { Ornamental, madeira } \\
\text { para } \\
\text { interna, lenha e } \\
\text { carvão }\end{array}$ \\
\hline Canelão & $\begin{array}{l}\text { Madeira para } \\
\text { móveis }\end{array}$ & $\begin{array}{l}\text { Canelão- } \\
\text { amarelo }\end{array}$ & Ocotea velutina & $\begin{array}{lr}\text { Madeira } & \text { para } \\
\text { construção } & \text { civil, } \\
\text { frutos apreciados } \\
\text { pela avifauna, } \\
\text { apropriada para } \\
\text { reflorestamento }\end{array}$ \\
\hline Canelinha & Madeira de lei & Canelinha & $\begin{array}{c}\text { Nectandra } \\
\text { megapotamica }\end{array}$ & \begin{tabular}{ll}
$l$ & \multicolumn{2}{l}{ Ornamental, } \\
Madeira para & \\
construção & civil \\
(apesar do odor \\
característico), \\
frutos apreciados \\
pela avifauna, \\
apropriada para \\
reflorestamento
\end{tabular} \\
\hline $\begin{array}{l}\text { Caraguatá, } \\
\text { gravatá }\end{array}$ & $\begin{array}{l}\text { Xarope da fruta } \\
\text { para tosse }\end{array}$ & Caraguatá & $\begin{array}{l}\text { Bromelia } \\
\text { balansae }\end{array}$ & $\begin{array}{l}\text { Frutos diuréticos, } \\
\text { vermífugos. Xarope } \\
\text { dos frutos para } \\
\text { asma, bronquite, } \\
\text { ancilostomose. } \\
\text { Bochecho do chá } \\
\text { das folhas com } \\
\text { própolis para feridas } \\
\text { na mucosa bucal. }\end{array}$ \\
\hline Caruru & $\begin{array}{l}\text { Comida para } \\
\text { porcos }\end{array}$ & $\begin{array}{l}\text { Caruru, } \\
\text { amaranto- } \\
\text { verde }\end{array}$ & $\begin{array}{c}\text { Amaranthus } \\
\text { viridis }\end{array}$ & $\begin{array}{l}\text { Alimento de suínos, } \\
\text { folhas e raízes são } \\
\text { diurético, laxante e } \\
\text { para catarro na } \\
\text { bexiga. }\end{array}$ \\
\hline $\begin{array}{l}\text { Cedro- } \\
\text { branco }\end{array}$ & $\begin{array}{l}\text { Madeira para } \\
\text { móvel }\end{array}$ & $\begin{array}{l}\text { Cedro- } \\
\text { branco }\end{array}$ & Guarea guidonia & \begin{tabular}{lr}
\multicolumn{3}{c}{ Ornamental, madeira } \\
para construção civil \\
e naval, frutos \\
apreciados \\
fauna, apela \\
\end{tabular} \\
\hline
\end{tabular}




\begin{tabular}{|c|c|c|c|c|}
\hline & & & & $\begin{array}{l}\text { para reflorestamento } \\
\text { de áreas degradadas }\end{array}$ \\
\hline $\begin{array}{c}\text { Cedro- } \\
\text { vermelho }\end{array}$ & Madeira & $\begin{array}{l}\text { Cedro- } \\
\text { vermelho }\end{array}$ & Cedrella fissilis & $\begin{array}{l}\text { Madeira para } \\
\text { construção civil e } \\
\text { naval, móveis e } \\
\text { esculturas }\end{array}$ \\
\hline Cinzeiro & $\begin{array}{l}\text { Madeira leve, } \\
\text { para jangada }\end{array}$ & $\begin{array}{l}\text { Cinzeiro, } \\
\text { caixeta }\end{array}$ & $\begin{array}{l}\text { Vochysia } \\
\text { tucanorum }\end{array}$ & $\begin{array}{l}\text { Ornamental, madeira } \\
\text { para caixotaria, } \\
\text { brinquedos e lenha, } \\
\text { apropriada para } \\
\text { reflorestamento }\end{array}$ \\
\hline $\begin{array}{c}\text { Erva-de- } \\
\text { bicho-roxa }\end{array}$ & $\begin{array}{l}\text { Chá da folha } \\
\text { para pneumonia }\end{array}$ & $\begin{array}{c}\text { Erva-de- } \\
\text { bicho-roxa }\end{array}$ & $\begin{array}{c}\text { Polygonum } \\
\text { hydropiperoides }\end{array}$ & 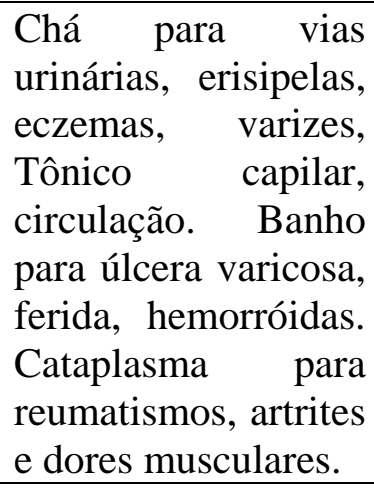 \\
\hline $\begin{array}{l}\text { Erva-de- } \\
\text { rato }\end{array}$ & $\begin{array}{c}\text { O leite é } \\
\text { venenoso para o } \\
\text { gado }\end{array}$ & $\begin{array}{l}\text { Erva-de- } \\
\text { rato }\end{array}$ & Asclepias sp & Planta tóxica \\
\hline $\begin{array}{l}\text { Erva-de- } \\
\text { São-João }\end{array}$ & $\begin{array}{l}\text { Folha torrada ou } \\
\text { Sumo para } \\
\text { cicatrizar } \\
\text { machucadura } \\
\end{array}$ & $\begin{array}{l}\text { Erva-de- } \\
\text { São-João }\end{array}$ & $\begin{array}{l}\text { Pyrostegia } \\
\text { venustato }\end{array}$ & $\begin{array}{l}\text { Regulador do ciclo } \\
\text { menstrual, calmante } \\
\text { e combate o vitiligo } \\
\text { e manchas na pele }\end{array}$ \\
\hline $\begin{array}{l}\text { Farinha- } \\
\text { seca }\end{array}$ & Madeira & $\begin{array}{l}\text { Farinha- } \\
\text { seca }\end{array}$ & Albizia hasslerii & $\begin{array}{l}\text { Madeira para forros } \\
\text { e objetos leve, } \\
\text { pioneira apropriada } \\
\text { para recomposição } \\
\text { de áreas degradadas }\end{array}$ \\
\hline Gabiroba & Alimento & $\begin{array}{l}\text { Gabiroba, } \\
\text { gabiroba- } \\
\text { do-campo }\end{array}$ & $\begin{array}{c}\text { Campomanesia } \\
s p\end{array}$ & $\begin{array}{l}\text { Madeira } \\
\text { instrumentos } \\
\text { musicais, cabos, } \\
\text { lenha e carvão, } \\
\text { frutos apreciados } \\
\text { pela avifauna }\end{array}$ \\
\hline Goiabeira & Alimento & goiabeira & Psidium guajava & $\begin{array}{l}\text { Chá das folhas para } \\
\text { diarréia, úlceras, } \\
\text { bochechos } \\
\text { carcarejos para } \\
\text { inflamações da boca } \\
\text { e da garganta. }\end{array}$ \\
\hline $\begin{array}{l}\text { Goiabeira- } \\
\text { do-mato }\end{array}$ & Alimento & $\begin{array}{l}\text { Goiaba-do- } \\
\text { campo }\end{array}$ & Acca sellowiana & \\
\hline Ipê-amarelo & $\begin{array}{l}\text { Bonito e difícil } \\
\text { de ver nesse } \\
\text { cerrado }\end{array}$ & $\begin{array}{l}\text { Ipê- } \\
\text { amarelo-do- } \\
\text { cerrado }\end{array}$ & Tabebuia aurea & $\begin{array}{l}\text { Ornamental, xarope } \\
\text { da casca do caule } \\
\text { para gripes e }\end{array}$ \\
\hline
\end{tabular}




\begin{tabular}{|c|c|c|c|c|}
\hline & & & & resfriados \\
\hline Jatobá & $\begin{array}{l}\text { Alimento, casca } \\
\text { de jatobá para } \\
\text { úlcera de } \\
\text { estômago, para } \\
\text { fazer vinho }\end{array}$ & jatobá & $\begin{array}{c}\text { Hymenaea } \\
\text { courbaril }\end{array}$ & $\begin{array}{l}\text { Casca moída para } \\
\text { diarréia, seiva para } \\
\text { tosse e bronquite, } \\
\text { xarope para asma, } \\
\text { laringite, catarro, } \\
\text { chá da casca para } \\
\text { problemas } \\
\text { estomacais e fungos } \\
\text { nos pés. }\end{array}$ \\
\hline $\begin{array}{l}\text { Jequitibá- } \\
\text { paulista }\end{array}$ & $\begin{array}{l}\text { Madeira para } \\
\text { móveis }\end{array}$ & $\begin{array}{l}\text { Jequitibá- } \\
\text { rosa }\end{array}$ & $\begin{array}{l}\text { Cariniana } \\
\text { legalis }\end{array}$ & $\begin{array}{l}\text { Ornamental, madeira } \\
\text { para construção } \\
\text { cível e móveis }\end{array}$ \\
\hline Juá-bravo & $\begin{array}{l}\text { Fruto cozido na } \\
\text { água e amassado } \\
\text { com sabão para } \\
\text { Furúnculo }\end{array}$ & Juá-bravo & Solanum viarum & $\begin{array}{ll}\text { (informação não } \\
\text { encontrada) }\end{array}$ \\
\hline Jurubeba & $\begin{array}{l}\text { Culinária, dor } \\
\text { de barriga }\end{array}$ & Jurubeba & $\begin{array}{c}\text { Solanum } \\
\text { paniculatum }\end{array}$ & $\begin{array}{l}\text { Fruto como } \\
\text { condimento, raízes, } \\
\text { folhas e frutos para } \\
\text { anemia, problemas } \\
\text { no fígado e vesícula, } \\
\text { hepatite e gastrite } \\
\text { crônicas, anemias, } \\
\text { febres intermitentes, } \\
\text { tumores uterinos e } \\
\text { ressaca. }\end{array}$ \\
\hline $\begin{array}{l}\text { Limão- } \\
\text { bravo }\end{array}$ & $\begin{array}{c}\text { Usado em } \\
\text { rituais religiosos }\end{array}$ & $\begin{array}{l}\text { Limão- } \\
\text { bravo }\end{array}$ & $\begin{array}{c}\text { Monimiaceae } \\
\text { Siparuna } \\
\text { guianensis } \\
\end{array}$ & $\begin{array}{ll}\text { (informação não } \\
\text { enocontrada) }\end{array}$ \\
\hline $\begin{array}{l}\text { Língua-de- } \\
\text { vaca }\end{array}$ & $\begin{array}{l}\text { Folha torrada } \\
\text { para ferida }\end{array}$ & $\begin{array}{l}\text { Língua-de- } \\
\text { vaca }\end{array}$ & $\begin{array}{l}\text { Elephantopus } \\
\text { mollis }\end{array}$ & $\begin{array}{l}\text { Chá da raiz é tônico, } \\
\text { diurético, } \\
\text { antitérmico, } \\
\text { antiséptico, herpes e } \\
\text { cálculos renais. Chá } \\
\text { das folhas para } \\
\text { bronquite, tosse, } \\
\text { gripe e resfriados. } \\
\text { Folhas frescas } \\
\text { úlceras e feridas. }\end{array}$ \\
\hline $\begin{array}{l}\text { Mamica-de- } \\
\text { porca }\end{array}$ & Cabo de enxada & $\begin{array}{l}\text { Mamica-de- } \\
\text { porca }\end{array}$ & $\begin{array}{l}\text { Zanthoxylum } \\
\text { hasslerianum }\end{array}$ & $\begin{array}{l}\text { Folhas raízes e casca } \\
\text { para vitiligo e outras } \\
\text { manchas da pele, } \\
\text { depurativo do } \\
\text { sangue tosse, gripe, } \\
\text { resfriado } \\
\text { bronquite. Madeira } \\
\text { para marcenaria e } \\
\text { lenha }\end{array}$ \\
\hline Manjericão- & Chá da folha e & Gervão-azul & Stachytarpheta & Chá das partes \\
\hline
\end{tabular}




\begin{tabular}{|c|c|c|c|c|}
\hline do-campo & flor para gripe & & $s p$. & $\begin{array}{l}\text { aéreas para febre, } \\
\text { diurético, estômago, } \\
\text { fígado, hepatite }\end{array}$ \\
\hline $\begin{array}{l}\text { Manjericão- } \\
\text { do-mato }\end{array}$ & & Cambará & & $\begin{array}{l}\text { Xarope das folhas e } \\
\text { flores para febre, } \\
\text { tosse, bronquite, } \\
\text { resfriado, catarro, } \\
\text { rouquidão, asma e } \\
\text { coqueluche. Chá das } \\
\text { folhas para } \\
\text { reumatismo, } \\
\begin{array}{l}\text { contusões, } \\
\text { esfoladuras, dores } \\
\text { musculares e nas } \\
\text { articulações }\end{array}\end{array}$ \\
\hline Marfim & $\begin{array}{c}\text { Madeira } \\
\text { especial, usada } \\
\text { para varal de boi }\end{array}$ & $\begin{array}{l}\text { Marfim, } \\
\text { pau-marfim }\end{array}$ & $\begin{array}{l}\text { Balfourodendron } \\
\text { riedelianum }\end{array}$ & $\begin{array}{l}\text { Madeira para móveis } \\
\text { de luxo, molduras e } \\
\text { torneados, } \\
\text { carpintaria } \\
\text { marcenaria em geral }\end{array}$ \\
\hline $\begin{array}{l}\text { Marmelo- } \\
\text { do-campo }\end{array}$ & Alimento & $\begin{array}{l}\text { Marmelada- } \\
\text { de- } \\
\text { cachorro, } \\
\text { marmelinho }\end{array}$ & Alibertia sessilis & $\begin{array}{l}\text { Informação não } \\
\text { encontrada }\end{array}$ \\
\hline $\begin{array}{l}\text { Marolo-do- } \\
\text { mato }\end{array}$ & Alimento & $\begin{array}{l}\text { Araticum- } \\
\text { do-campo, } \\
\text { marolo }\end{array}$ & Annona coriacea & $\begin{array}{l}\text { Alimento apreciado } \\
\text { pela avifauna }\end{array}$ \\
\hline $\begin{array}{l}\text { Melão-de- } \\
\text { São- } \\
\text { Caetano }\end{array}$ & $\begin{array}{l}\text { Tomar e banhar } \\
\text { com o chá da } \\
\text { folha para } \\
\text { hepatite }\end{array}$ & $\begin{array}{l}\text { Melão-de- } \\
\text { São- } \\
\text { Caetano }\end{array}$ & $\begin{array}{l}\text { Momordica } \\
\text { charantia }\end{array}$ & $\begin{array}{l}\text { Folhas para } \\
\text { hemorróidas, } \\
\text { anemia, diarréia, } \\
\text { como repelente de } \\
\text { pulgas e do } \\
\text { ancilostomídeo da } \\
\text { larva-migrans, } \\
\text { febrífugo, } \\
\text { vermífugo, } \\
\text { hipotensor, } \\
\text { hipoglicemiante, } \\
\text { antileucêmico, } \\
\text { antitumoral } \\
\text { antiviral }\end{array}$ \\
\hline $\begin{array}{l}\text { Óleo-de- } \\
\text { capaúba }\end{array}$ & $\begin{array}{l}\text { Óleo do cerne } \\
\text { para dor no } \\
\text { corpo }\end{array}$ & $\begin{array}{l}\text { Copaíba, } \\
\text { óleo-de- } \\
\text { copaíba, } \\
\text { copaúba }\end{array}$ & $\begin{array}{l}\text { Copaifera } \\
\text { langsdorffii }\end{array}$ & $\begin{array}{l}\text { Óleo antibiótico, } \\
\text { repelente de insetos, } \\
\text { cicatrizante, anti- } \\
\text { inflamatório local, } \\
\text { expectorante, para } \\
\text { doenças de pele, } \\
\text { afeções urinárias e } \\
\text { da garganta. }\end{array}$ \\
\hline Olho-de- & Fazer relíquia & Olho-de- & Ormosia & Ornamental, madeira \\
\hline
\end{tabular}




\begin{tabular}{|c|c|c|c|c|}
\hline cabra & & cabra, tento & arborea & $\begin{array}{ll}\text { para móveis } & \text { e } \\
\text { acabamentos } & \\
\text { internos } & \text { de } \\
\text { construções } & \end{array}$ \\
\hline Pariparoba & $\begin{array}{l}\text { Chá das folhas } \\
\text { tira inflamação } \\
\text { dos rins }\end{array}$ & $\begin{array}{l}\text { Pariparoba, } \\
\text { capeva }\end{array}$ & $\begin{array}{c}\text { Piper } \\
\text { umbellatum }\end{array}$ & $\begin{array}{l}\text { Informação não } \\
\text { encontrada }\end{array}$ \\
\hline $\begin{array}{l}\text { Pata-de- } \\
\text { vaca }\end{array}$ & diabetes & $\begin{array}{l}\text { Pata-de- } \\
\text { vaca, unha- } \\
\text { de-vaca }\end{array}$ & $\begin{array}{l}\text { Bauhinia } \\
\text { forficata }\end{array}$ & $\begin{array}{lr}\begin{array}{l}\text { Chá das folhas para } \\
\text { diabetes, } \\
\text { renais, }\end{array} & \text { cálculos } \\
\text { parasititeses, } & \\
\text { intestinais } & \\
\text { elefantíase } & \end{array}$ \\
\hline $\begin{array}{l}\text { Pau-de- } \\
\text { espeto }\end{array}$ & $\begin{array}{l}\text { Espeto, esticar } \\
\text { couro }\end{array}$ & $\begin{array}{l}\text { Pau-de- } \\
\text { espeto, } \\
\text { espeteiro }\end{array}$ & $\begin{array}{c}\text { Casearia } \\
\text { gossypiosperma }\end{array}$ & $\begin{array}{l}\text { Ornamental, madeira } \\
\text { para construção } \\
\text { civil, caixotaria e } \\
\text { brinquedos }\end{array}$ \\
\hline $\begin{array}{l}\text { Peroba-do- } \\
\text { campo }\end{array}$ & & $\begin{array}{l}\text { Peroba-do- } \\
\text { campo }\end{array}$ & $\begin{array}{l}\text { Aspidospermum } \\
\text { tomentosum }\end{array}$ & Uso da madeira \\
\hline $\begin{array}{l}\text { Pimenta-de- } \\
\text { macaco }\end{array}$ & & $\begin{array}{l}\text { Pimenta-de- } \\
\text { macaco }\end{array}$ & $\begin{array}{c}\text { Xylopia } \\
\text { aromatica }\end{array}$ & $\begin{array}{l}\text { Sementes torradas e } \\
\text { moídas e tintura da } \\
\text { casca do caule como } \\
\text { excitante, } \\
\text { carminativo } \\
\text { afrodisíaco }\end{array}$ \\
\hline $\begin{array}{l}\text { Pinha-do- } \\
\text { campo }\end{array}$ & Alimento & Araticum & Annona coriacea & $\begin{array}{l}\text { Bochechos com o } \\
\text { chá das folhas para } \\
\text { estomatite, } \\
\text { nevralgias e cefaléia, } \\
\text { cataplasma das } \\
\text { folhas para } \\
\text { furúnculos e úlceras }\end{array}$ \\
\hline $\begin{array}{l}\text { Quina- } \\
\text { cruzeiro }\end{array}$ & $\begin{array}{l}\text { Chá da raiz para } \\
\text { machucadura, } \\
\text { estômago, cólica }\end{array}$ & $\begin{array}{l}\text { Quina- } \\
\text { cruzeira }\end{array}$ & $\begin{array}{c}\text { Strychnos } \\
\text { pseudo-quina }\end{array}$ & $\begin{array}{l}\text { Madeira, fruto } \\
\text { comestível, indicada } \\
\text { para baço, fígado, } \\
\text { estômago, malária }\end{array}$ \\
\hline $\begin{array}{l}\text { Rebentão- } \\
\text { do-campo }\end{array}$ & & & $\begin{array}{c}\text { Classificação } \\
\text { não encontrada }\end{array}$ & \\
\hline $\begin{array}{l}\text { Sangria- } \\
\text { d’água }\end{array}$ & $\begin{array}{c}\text { Casca da árvore } \\
\text { cozida para } \\
\text { lavar ferida }\end{array}$ & $\begin{array}{l}\text { Sangra- } \\
\text { d’água, } \\
\text { drago }\end{array}$ & $\begin{array}{c}\text { Croton } \\
\text { urucurana }\end{array}$ & $\begin{array}{l}\text { Resina e casca para } \\
\text { ferimento } \\
\text { (cicatrizante e evitar } \\
\text { infecção, estancar } \\
\text { sangramento }\end{array}$ \\
\hline Sapuva & Cabo de enxada & Sapuva & $\begin{array}{c}\text { Machaerium } \\
\text { brasiliense }\end{array}$ & \\
\hline Sucupira & $\begin{array}{c}\text { Sinusite (9 } \\
\text { sementes } \\
\text { furadas, } \\
\text { biotônico, } 1 \\
\text { colher de álcool, }\end{array}$ & $\begin{array}{l}\text { Sucupira, } \\
\text { sucupira- } \\
\text { branca, } \\
\text { faveiro }\end{array}$ & $\begin{array}{c}\text { Pterodon } \\
\text { emarginatus }\end{array}$ & $\begin{array}{lr}\text { Óleo aromático da } \\
\text { casca do caule e dos } \\
\text { frutos inibe } \\
\text { penetração } \\
\text { cercaria }\end{array}$ \\
\hline
\end{tabular}




\begin{tabular}{|c|c|c|c|l|}
\hline & $\begin{array}{c}\text { sementes de 1 } \\
\text { romã) }\end{array}$ & & & $\begin{array}{l}\text { esquistossomosse. } \\
\text { Túberas radiculares } \\
\text { para diabetes. }\end{array}$ \\
\hline $\begin{array}{c}\text { Unha-de- } \\
\text { vaca }\end{array}$ & Para os rins & $\begin{array}{c}\text { Unha-de- } \\
\text { vaca, pata- } \\
\text { de-vaca }\end{array}$ & Bauhinia sp & $\begin{array}{l}\text { Chá das folhas para } \\
\text { hiperglicemia, } \\
\text { cálculos renais, } \\
\text { diurética. }\end{array}$ \\
\hline Urtiga & Provoca coceira & Urtiga, & Urtica dioica & $\begin{array}{l}\text { Chá das folhas e } \\
\text { raízes como anti- } \\
\text { reumático, anti- } \\
\text { séptico, bactericida, } \\
\text { adstringente, } \\
\text { diurético-depurativo, } \\
\text { estimulante anti- } \\
\text { circulatório, and } \\
\text { anêmico a } \\
\text { afrodisíaco }\end{array}$ \\
\hline
\end{tabular}


ANEXO 16

Questão 01 Componentes descritos com base no mapa mental - EE Aracy Pereira Lopes.

\begin{tabular}{|c|c|c|}
\hline Tipos de componentes & 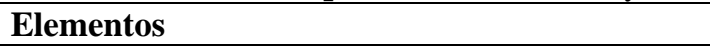 & citações \\
\hline \multirow[t]{4}{*}{ Relevo, topografia } & Barroca & 1 \\
\hline & Vale & 4 \\
\hline & Morro & 2 \\
\hline & Buracão (goiabinha) & 1 \\
\hline \multirow[t]{3}{*}{ Solo e rochas } & Areião, Areia, solo arenoso, areieiro & 11 \\
\hline & Pedras, rochas & 5 \\
\hline & Argila, Barro & 3 \\
\hline \multirow[t]{8}{*}{ Água } & Água limpa & 3 \\
\hline & Nascente (minas) & 7 \\
\hline & Rio Água Quente, Córrego Água Quente & 7 \\
\hline & Córrego, Rios & 4 \\
\hline & Laguinho, lagos & 2 \\
\hline & Aqüífero Guarani & 1 \\
\hline & Água suja, rio poluído & 3 \\
\hline & Esgoto, água sanitária & 3 \\
\hline \multirow[t]{5}{*}{ Vegetação } & Matagal 1 Matos 5 & 6 \\
\hline & Área verde 1Mata 7 Cerrado 1 Muitas árvores 12 & 21 \\
\hline & Árvores frutíferas 1 Frutos 1 & 2 \\
\hline & Flores & 1 \\
\hline & Plantas medicinais & 1 \\
\hline \multirow[t]{11}{*}{ Fauna } & Animais & 7 \\
\hline & Insetos 4 Pernilongos 1 Abelhas 1 & 6 \\
\hline & Aranhas 2 Escorpião 1 & 3 \\
\hline & Cobras & 2 \\
\hline & Morcego & 1 \\
\hline & Cachorro-do-mato & 1 \\
\hline & Pássaros & 2 \\
\hline & Lebre & 1 \\
\hline & Peixe & 1 \\
\hline & Tatus & 1 \\
\hline & Sapos & 2 \\
\hline \multirow[t]{7}{*}{ Componentes construídos } & Ruas & 2 \\
\hline & Trilha & 1 \\
\hline & Casas & 2 \\
\hline & Torres de energia & 1 \\
\hline & Terrenos vazios & 1 \\
\hline & Escola & 3 \\
\hline & Cemitério & 3 \\
\hline \multirow[t]{3}{*}{ Resíduos sólidos } & Lixo & 4 \\
\hline & Entulhos & 2 \\
\hline & Animais mortos (vaca) & 4 \\
\hline Erosões & Erosões (avalanche, buraco) & 7 \\
\hline \multirow[t]{3}{*}{ Outros } & Queimadas & 3 \\
\hline & Desmatamento & 1 \\
\hline & Cavernas & 1 \\
\hline
\end{tabular}

Questão 01 Componentes descritos com base no mapa mental EE Orlando Perez.

\begin{tabular}{|l|l|c|}
\hline Tipos de componentes & Elementos & Número de citações \\
\hline \multirow{4}{*}{ Relevo, topografia } & Buraco, barranco & $\mathbf{3}$ \\
\cline { 2 - 3 } & Vale & $\mathbf{3}$ \\
\cline { 2 - 3 } & Morro, morro com pedras, rochas & $\mathbf{1 3}$ \\
\hline \multirow{3}{*}{ Solo e rochas } & Terra suja & 1 \\
\cline { 2 - 3 } & Formações rochosas & 1 \\
\cline { 2 - 3 } & Pedreira da (Bandeirantes) & 1 \\
\hline
\end{tabular}




\begin{tabular}{|c|c|c|}
\hline & Areia, areião & 1 \\
\hline \multirow[t]{6}{*}{ Água } & Rios sujos, minas contaminadas & 3 \\
\hline & nascentes de rios & 3 \\
\hline & Esgoto (com odor forte) & 7 \\
\hline & Lagos & 1 \\
\hline & Rio, Córregos, um córrego, riozinho & 5 \\
\hline & Córrego da Água Quente & 5 \\
\hline \multirow[t]{3}{*}{ Vegetação } & Pastos & 2 \\
\hline & Matas, muito verde, árvores,vegetação & 19 \\
\hline & Mato & 11 \\
\hline \multirow[t]{3}{*}{ Fauna } & Baratas, ratos, mosquito, outros insetos & 5 \\
\hline & Cobras & 1 \\
\hline & Muitos bichos, animais & 3 \\
\hline \multirow[t]{8}{*}{ Componentes construídos } & $\begin{array}{l}\text { uma rua que liga os bairros Cidade Aracy } \\
\text { I e II e o Antenor Garcia ao centro da } \\
\text { cidade }\end{array}$ & 2 \\
\hline & Motocross, campos de futebol & 5 \\
\hline & Canteiro, praça & 2 \\
\hline & Cemitério & 2 \\
\hline & terrenos baldios & 2 \\
\hline & Barracos, Loteamentos & 2 \\
\hline & Fazendas, Chácaras & 3 \\
\hline & Estradas, Linha de trem & 2 \\
\hline \multirow[t]{2}{*}{ Resíduos sólidos } & Lixão, lixo acumulado & 5 \\
\hline & Entulho & 2 \\
\hline Erosões & & 2 \\
\hline
\end{tabular}

Componentes descritos com base no mapa mental - EE Maria Ramos.

\begin{tabular}{|c|c|c|}
\hline Tipos de componentes & Elementos & Número de citações \\
\hline \multirow[t]{3}{*}{ Relevo, topografia } & $\begin{array}{l}\text { Buraco, buracão, cratera, barroca, } \\
\text { barrancos, baixada }\end{array}$ & 16 \\
\hline & Vale & 2 \\
\hline & Morro (do Aracy), serra & 6 \\
\hline \multirow[t]{4}{*}{ Solo e rochas } & Terra suja & 1 \\
\hline & Formações rochosas & 2 \\
\hline & Pedreira da (Bandeirantes) & 4 \\
\hline & Areia, areião & 2 \\
\hline \multirow[t]{5}{*}{ Água } & Rio sujo (poluído), água poluída & 3 \\
\hline & Esgoto, rio de esgoto & 6 \\
\hline & Lagos & 1 \\
\hline & Rio, Córrego & 5 \\
\hline & Rio ou córrego Água Quente & 2 \\
\hline \multirow[t]{3}{*}{ Vegetação } & Descampado com grama, pastagem & 3 \\
\hline & Vegetação, árvores, mata nativa & 9 \\
\hline & Mato & 15 \\
\hline \multirow[t]{2}{*}{ Fauna } & Bichos, aranhas, cobras, cachorros & 4 \\
\hline & Pássaros, pequenos animais & 3 \\
\hline \multirow[t]{3}{*}{ Componentes construídos } & $\begin{array}{l}\text { Ruas esburacadas, canos estourados, } \\
\text { terrenos vazios (em relação aos bairros) }\end{array}$ & 3 \\
\hline & Fazendas & 1 \\
\hline & Trilha & 1 \\
\hline \multirow[t]{2}{*}{ Resíduos sólidos } & Lixo (tóxico), resíduos & 7 \\
\hline & Entulho & 10 \\
\hline
\end{tabular}


ANEXO 17 Questão 03: Existe alguma área verde em seu bairro? Você já visitou?

Respostas que indicam que a área verde da microbacia é considerada como área de vegetação próxima ao bairro onde residem (entre parênteses está indicado o bairro de cada respondente)

\section{EE ARACY PEREIRA LOPES -}

(MONTE CARLO) sim, existe uma grande área de vegetação lá no buracão, mas nunca visitei.

(ARACY I) sim, que eu visitei só o vale.

(ANTENOR GARCIA) atrás de minha casa. já um monte de vezes.

(ARACY I) sim, como eu já citei, tem o vale eu é muito bonito e deveríamos explorá-lo mais.

(ANTENOR GARCIA) Sim, o vale. Buracão, Água Fria.

(ANTENOR GARCIA) no vale entre Monte Carlo e Cidade Aracy, mas eu nunca visitei.

\section{EE ORLANDO PEREZ}

(Cidade Aracy II) Sim, o vale, mas eu nunca visitei.

(Cidade Aracy I) Aqui no bairro em que moro é uma das coisas que mais tem vegetação, existem muitas matas em volta do bairro, uma vez saí com minha mãe e algumas pessoas para ver, e vi muitas flores e árvores bonitas na mata que fica bem próxima à minha casa.

(Cidade Aracy II) Sim, perto de casa tem uma vegetação e lá é uma mata totalmente fechada e eu nunca visitei e não pretendo ir visitar.

(Cidade Aracy I) Sim, existe o vale e uma mata, mas nunca visitei.

(Cidade Aracy I) Sim. Perto e dentro do bairro. O "vale” é um local cheio de natureza. (“daria até para ser parque ecológico”) se fosse cuidado. Eu já visitei várias vezes.

(Cidade Aracy I) sim, já uma vez com uma professora que nos levou no vale para ver uma nascente.

(Cidade Aracy) Sim, já visitei uma vez o Córrego da Água Quente em sua nascente.

(Cidade Aracy I) Sim, o vale mais só passei por lá, não parei pra ficar observando.

(Cidade Aracy) Sim, próximo ao Córrego da Água Quente.

\section{EE MARIA RAMOS}

(Jardim Cruzeiro do Sul) "Existe, mas com o tempo realmente está virando bairro, é muito bonito, um lugar gostaria de ficar, mas é perigoso porque há lixo e traficantes andando próximo de nós”.

(Vila Isabel) "Sim, tem bem em frente à minha casa, já visitei, passo por ele todos os dias, lá eu vejo flores, lixos, entulhos e bichos (vivos e mortos)".

(Jardim Cruzeiro do Sul) "O local em que moro existe bastante vegetação, há um bosque, uma área denominada cafezal, onde tem alguns pés de café”.

(Botafogo) "Existe e já tive a oportunidade de visitar algumas cachoeiras que tem lá perto há um tempo atrás”.

(Pacaembu) "Existe vegetação sim, eu já visitei uma vegetação que fica entre os bairros Pacaembu, Gonzaga, Monte Carlo".

(Jardim Beatriz) “Tem perto da Bandeirantes uma vegetação um pouco fechada. Também tem do Belvedere até o Antenor Garcia, um pedaço bem fechado e uma parte mais aberta. Já visitei essas duas vegetações".

(Pacaembu) "Sim, a barroca. Visitei somente uma vez e uma praça”. 
ANEXO 18 Questão 04: O que você já viu ou imagina que exista na área verde próxima à escola? Componentes da paisagem da área verde da microbacia, segundo a percepção das(os) estudantes

EE Aracy Pereira Lopes.

\begin{tabular}{|c|c|c|c|}
\hline \multicolumn{4}{|c|}{ COMPONENTES DA PAISAGEM } \\
\hline $\begin{array}{c}\text { TIPOS DE } \\
\text { COMPONENTES }\end{array}$ & \multicolumn{2}{|c|}{ ELEMENTOS DA PAISAGEM } & $\begin{array}{l}\text { NÚMERO DE } \\
\text { CITAÇÕES }\end{array}$ \\
\hline \multirow[t]{22}{*}{ Componentes naturais } & \multirow[t]{3}{*}{ Vegetação } & $\begin{array}{l}\text { Árvores, Goiabeira 2, } \\
\text { verde, mata, mato, cerrado }\end{array}$ & 11 \\
\hline & & $\begin{array}{l}\text { Planta medicinal (quebra- } \\
\text { pedra) }\end{array}$ & 1 \\
\hline & & Frutas & 2 \\
\hline & \multirow[t]{10}{*}{ Fauna } & Peixinhos & 1 \\
\hline & & Aves & 2 \\
\hline & & Lagartos & 3 \\
\hline & & $\begin{array}{l}\text { Coelho 3, Tatu galinha 1, } \\
\text { Gambá } 1\end{array}$ & 5 \\
\hline & & $\begin{array}{l}\text { Vacas 2, Cavalos 2, Bode } \\
1 \text {, Animais pastando } 2\end{array}$ & 7 \\
\hline & & Animais & 4 \\
\hline & & Insetos & 2 \\
\hline & & Aranha 1, Carrapato 2 & 3 \\
\hline & & $\begin{array}{l}\text { Cobras } 4 \text {, Cobra-cega } 1 \text {, } \\
\text { Coral falsa } 1\end{array}$ & 6 \\
\hline & & Sapo & 1 \\
\hline & \multirow[t]{2}{*}{ Relevo } & Buracão & 2 \\
\hline & & Vale & 2 \\
\hline & Solo e rochas & Argila 1 , areia 1 & 2 \\
\hline & & Pedras & 1 \\
\hline & & Cavernas & 1 \\
\hline & \multirow[t]{4}{*}{ Água } & Minas, nascente & 3 \\
\hline & & Rio 3, Córrego 1 & 1 \\
\hline & & Córrego da Água Quente & 1 \\
\hline & & Córrego sanitário & 1 \\
\hline \multirow{4}{*}{$\begin{array}{l}\text { Componentes } \\
\text { construídos }\end{array}$} & \multicolumn{2}{|c|}{ Torres de energia } & 1 \\
\hline & \multicolumn{2}{|c|}{ Cemitério } & 2 \\
\hline & \multicolumn{2}{|c|}{ Cerca } & 1 \\
\hline & \multicolumn{2}{|c|}{ Rastos de pessoas 1 , trilhas de pessoas 1} & 2 \\
\hline \multirow[t]{3}{*}{ Impactos ambientais } & \multicolumn{2}{|c|}{ Lixo 4, Roupas e sapatos 1} & 5 \\
\hline & \multicolumn{2}{|c|}{ Bichos mortos, vaca morta } & 4 \\
\hline & \multicolumn{2}{|c|}{ Erosões } & 1 \\
\hline \multicolumn{3}{|l|}{ Pessoas } & 2 \\
\hline
\end{tabular}


EE Orlando Perez

Componentes da paisagem da área verde da microbacia, segundo a percepção das(os) estudantes

\begin{tabular}{|c|c|c|c|}
\hline \multicolumn{4}{|c|}{ COMPONENTES DA PAISAGEM } \\
\hline TIPOS DE & \multicolumn{2}{|c|}{ ELEMENTOS DA PAISAGEM } & NÚMERO DE \\
\hline \multirow[t]{14}{*}{ Componentes naturais } & \multirow[t]{4}{*}{ Vegetação } & Mata & 5 \\
\hline & & Matos & 3 \\
\hline & & Flores & 1 \\
\hline & & Plantas & 3 \\
\hline & \multirow[t]{4}{*}{ Fauna } & Animais & 4 \\
\hline & & Veado, coelho, tatu & 3 \\
\hline & & Lagarto & 1 \\
\hline & & $\begin{array}{l}\text { Tucano, seriema, } \\
\text { periquito, pássaros }\end{array}$ & 4 \\
\hline & \multirow[t]{2}{*}{ Relevo } & Morros, serra & 4 \\
\hline & & Vale & 1 \\
\hline & \multirow[t]{4}{*}{ Água } & Nascentes & 2 \\
\hline & & Rios & 3 \\
\hline & & Córrego da Água Quente & 2 \\
\hline & & Água & 1 \\
\hline \multirow{3}{*}{$\begin{array}{l}\text { Componentes } \\
\text { construídos }\end{array}$} & \multicolumn{2}{|c|}{ Chácaras, fazendas } & 2 \\
\hline & \multicolumn{2}{|c|}{ Motocross } & 1 \\
\hline & \multicolumn{2}{|c|}{ Terrenos baldios } & 1 \\
\hline \multirow[t]{2}{*}{ Impacto ambiental } & \multicolumn{2}{|c|}{ Buraco, erosão } & 2 \\
\hline & \multicolumn{2}{|c|}{ Lixo, entulho } & 5 \\
\hline \multicolumn{3}{|l|}{ Pessoas } & 1 \\
\hline
\end{tabular}

\section{EE Maria Ramos}

Componentes da paisagem da área verde da microbacia, segundo a percepção das(os) estudantes.

\begin{tabular}{|c|c|c|c|}
\hline TIPOS DE & \multicolumn{2}{|c|}{ ELEMENTOS DA PAISAGEM } & NÚMERO DE \\
\hline \multirow[t]{14}{*}{ Componentes naturais } & \multirow[t]{4}{*}{ Vegetação } & $\begin{array}{l}\text { árvores, árvores } \\
\text { frutíferas (amora, } \\
\text { mangueira, goiabeira) }\end{array}$ & 11 \\
\hline & & Mato & 3 \\
\hline & & Flores & 1 \\
\hline & & Plantas medicinais & 1 \\
\hline & \multirow[t]{4}{*}{ Fauna } & Pássaros & 2 \\
\hline & & Animais, bichos & 2 \\
\hline & & Cobras & 1 \\
\hline & & Anfíbios & 1 \\
\hline & Rochas & Pedra & 1 \\
\hline & \multirow[t]{4}{*}{ Água } & Cachoeira & 1 \\
\hline & & Rio & 1 \\
\hline & & Córrego sujo & 1 \\
\hline & & água & 1 \\
\hline & Relevo & Barroca & 1 \\
\hline \multirow{2}{*}{$\begin{array}{l}\text { Componentes naturais } \\
\text { construídos }\end{array}$} & \multicolumn{2}{|c|}{ Bicão } & 1 \\
\hline & \multicolumn{2}{|c|}{ Baixada do Jardim Gonzaga } & 1 \\
\hline Impacto ambiental & \multicolumn{2}{|c|}{ Erosões } & 1 \\
\hline \multicolumn{3}{|l|}{ Não souberam responder } & 7 \\
\hline
\end{tabular}


ANEXO 19: TABULAÇÃO DOS QUESTIONÁRIOS DAS(OS) ESTUDANTES

1) Observando o mapa, descreva o que existe no espaço vazio entre os bairros.

\begin{abstract}
EE MARIA RAMOS
Atrás da Vila Monte Carlo onde passa o rio da água quente existe uma mata nativa e morros de rochas grandes entre o Belvedere, Jardim Gonzaga e Pacaembu. Existe um imenso buraco com bastante árvores e gramado e infelizmente onde caem o esgoto de muitas casas ao fundo do Antenor Garcia e Jardim Medeiros existem fazendas e pastos com mata nativa.
\end{abstract}

\title{
EE ARACY PEREIRA LOPES
}

Nesse espaço vazio há algumas arvores, mas o que mais tem na verdade é lixo, de pessoas que não tem consciência do que está causando para a nossa natureza. Entre este espaço tem muita coisa bonita, vários animais, nascente do rio.

Água Quente, o esgoto despejado no rio, lixos das casas que se localizam próximo ao rio. Próximo ao rio tem também uma avalanche, muito funda, atrás da escola Caic.

\section{EE ORLANDO PEREZ}

Os espaços vazios na minha opinião são morros, terrenos baldios, algumas nascentes, matas.

2) O que você observa no trajeto entre sua casa e a escola?

EE MARIA RAMOS (Pacaembu) Além de muitas casas e terrenos vazios um imenso buraco verde de árvores e plantas mais conhecido como barroca.

\section{EE ARACY PEREIRA LOPES}

(ANTENOR GARCIA) Muitos animais nas ruas, muitos buracos nas ruas que dificulta os trajetos dos ônibus e carros, e logo ao chegar no morro que sobre para o Monte Carlo tem muito lixo nos terrenos baldios e o esgoto no rio Água Quente.

\section{EE ORLANDO PEREZ}

(Cidade Aracy I) Ao ir à escola vejo novamente: muito mato alto cobrindo muita coisa, o morro do Cidade Aracy, muitos terrenos abandonados e muitas, muitas casas.

3) Existe alguma vegetação em seu bairro? Você já visitou?

\section{EE MARIA RAMOS}

(Pacaembu) Sim, a barroca. Visitei somente uma vez e uma praça.

\section{EE ARACY PEREIRA LOPES}

(ANTENOR GARCIA) sim, tem uma mata, que por vista é muito bonita, dá para respirar um pouco de ar puro, sentir o cheirinho de mato de terra.

\section{EE ORLANDO PEREZ}

(Cidade Aracy I) Sim. Perto e dentro do bairro. O “vale” é um local cheio de natureza. 
(“daria até para ser parque ecológico”) se fosse cuidado. Eu já visitei várias vezes.

4) O que você já viu ou imagina que exista de vegetação próximo ao bairro em que está inserida sua escola?

EE MARIA RAMOS

Fora o grande buraco verde (barroca) existe somente uma avenida chamada Avenida Grécia onde alguns moradores plantaram árvores de frutas entre outras plantas.

\section{EE ARACY PEREIRA LOPES}

No buracão tem muito lixo, animais, vacas, cavalos, algumas aves que fazem ninhos.

\section{EE ORLANDO PEREZ}

Existe muitas chácaram, fazendas, rios perto do Cidade Aracy. Eu já vi, visitei muito essas áreas citadas.

5) Quem são os responsáveis pela atual situação da área de vegetação existente próximo à sua escola, e quem deve decidir o que deveria ser feito naquele local?

\section{EE MARIA RAMOS}

Na minha opinião, os responsáveis pela situação atual de vegetação próxima à escola e pessoas que comandam a cidade, ou seja, prefeitos, vereadores e outros. Pessoas que entendem sobre vegetação é que deveriam decidir o que deve ser feito com a vegetação de nossa cidade.

\section{EE ARACY PEREIRA LOPES}

Os responsáveis pela situação são os moradores da redondeza.

\section{EE ORLANDO PEREZ}

Os responsáveis por esta área de vegetação deve ser a prefeitura. E quem deve decidir o que pode ser feito é (nós) o povo. Pois o bem é para nós mesmos.

6) Conte o que a área de vegetação próxima ao seu bairro e/ou à sua escola significa para você e o que você gostaria que fosse feito naquele local.

\section{EE MARIA RAMOS (BAIRRO PACAEMBU)}

O grande buraco verde: este grande buraco verde é chamado de barroca. Ele significa não só para mim mas para muitas pessoas que podemos ter o que muita população não tem, o oxigênio puro da natureza. Gostaria que este local se transformasse num grande parque natural, com muita vegetação, plantas, flores e animais e rios limpos. Onde as pessoas poderiam passear e até passar um fim de semana com sua família. Eu acho que se o homem tem a capacidade de destruir a natureza, ele também tem a capacidade de dar vida a ela. Basta querer.

\section{EE ARACY PEREIRA LOPES}

Gostaria que as pessoas se conscientizassem e não jogassem lixo na área de vegetação. Gostaria também que houvesse algo a fazer no rio, como água suja que 
joga no rio, não só pelo fato ser suja, tem um mau cheiro danado. Seria muito legal se ali no morro e em toda a redondeza fosse tudo muito limpinho.

\section{EE ORLANDO PEREZ}

No local de vegetação no bairro não é muito bom, não que eu seja pessimista, mas é que infelizmente temos que enxergar o óbvio. A natureza é mal tratada e são poucas as pessoas que se interessam em cultivá-la. Devido a despreocupação de muitas pessoas, vai surgindo coisas feias na natureza que ao invés de ser algo belo, acaba se tornando um estorvo. Onde acaba surgindo até violência na "minifloresta”. E para acabar com isso precisamos de ajuda, força de vontade e muito, muito incentivo para tornar um bairro belo e cheio de pessoas boas, mas infelizmente descriminadas pela fama que o bairro tem. Precisamos de incentivo! Precisamos mesmo! 
ANEXO 20: Participantes da pesquisa na MCAQ.

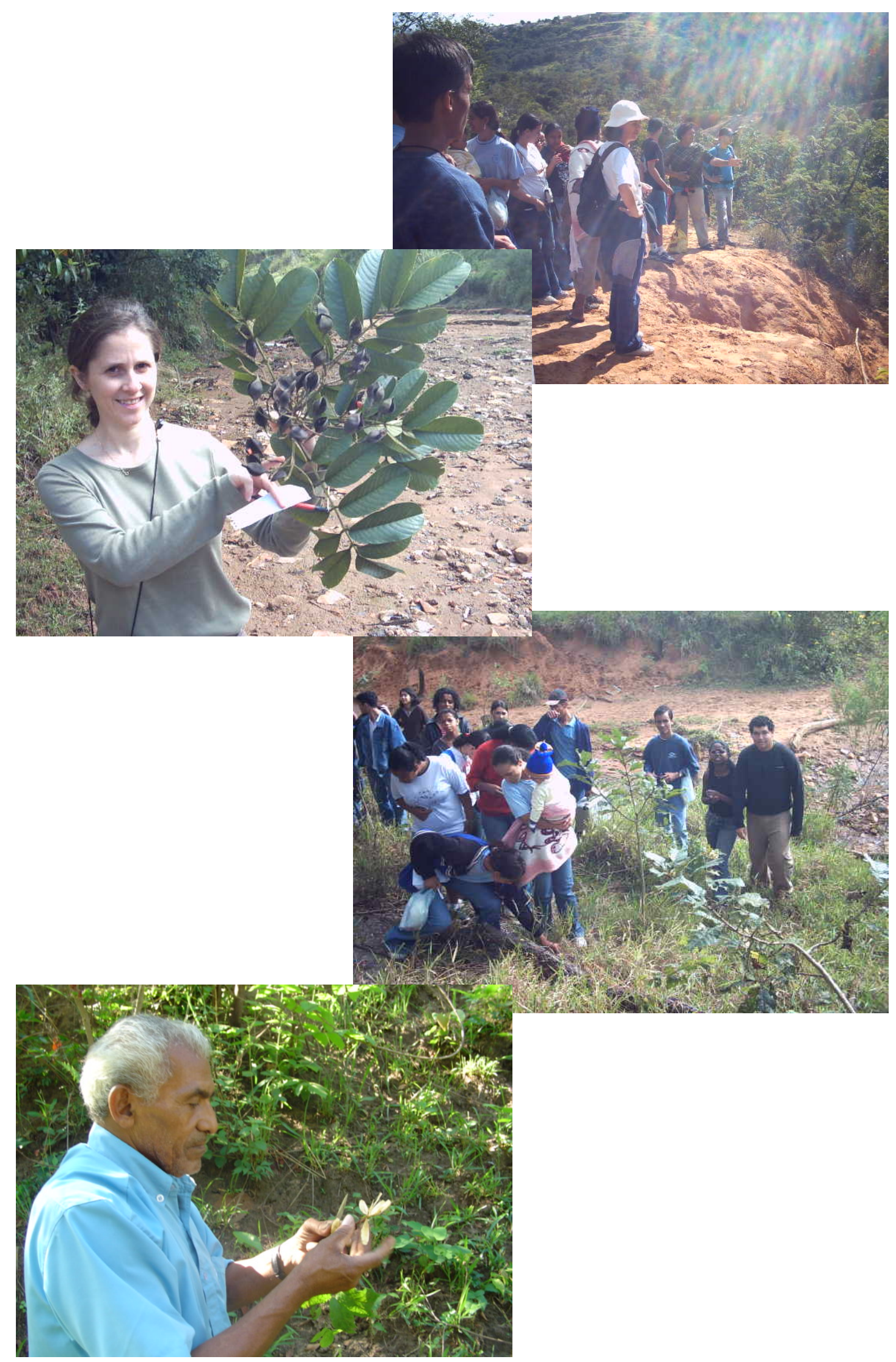



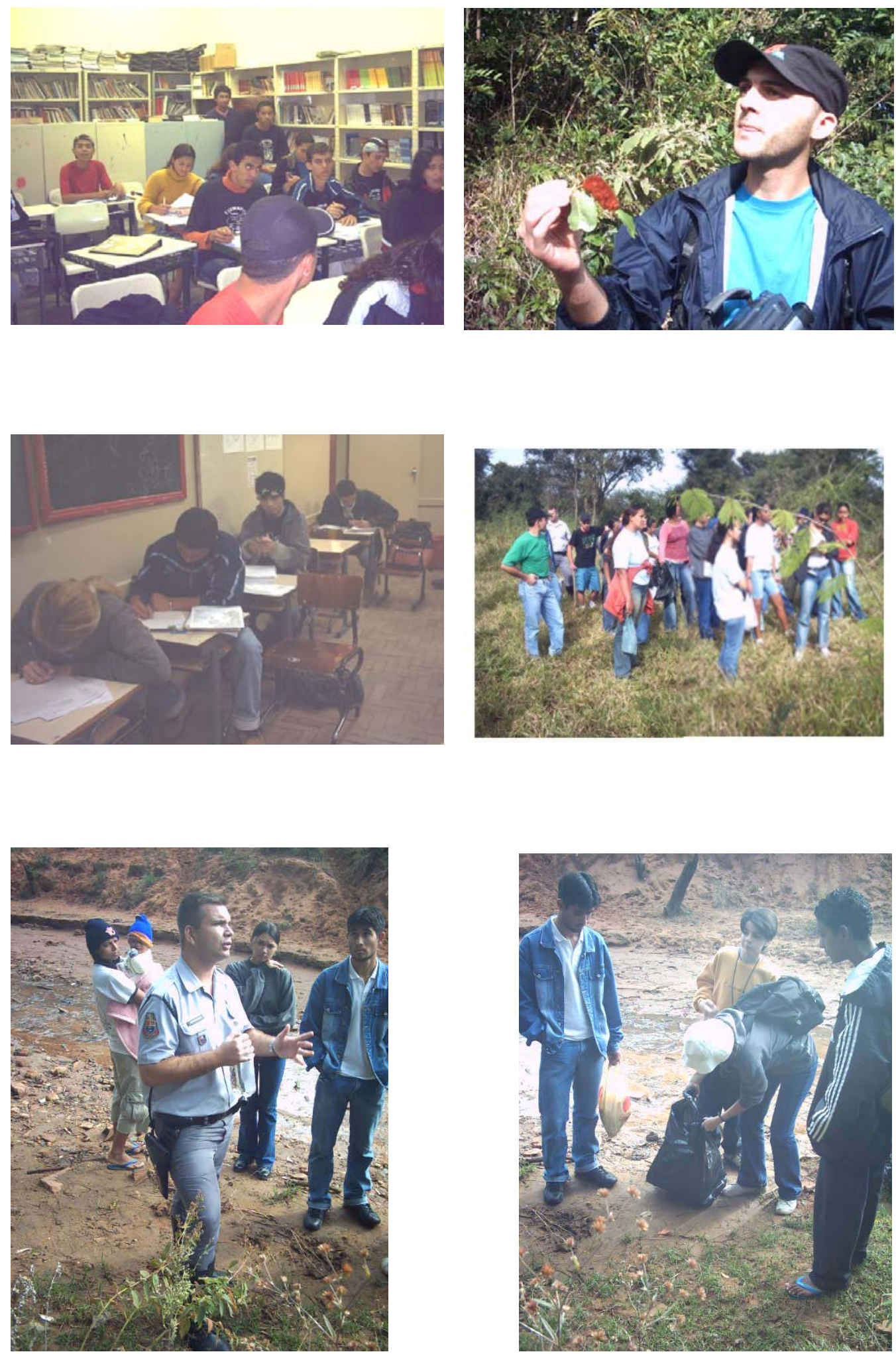